A FEA e a USP respeitam os direitos autorais deste trabalho. Nós acreditamos que a melhor proteção contra o uso ilegítimo deste texto é a publicação online. Além de preservar o conteúdo motiva-nos oferecer à sociedade o conhecimento produzido no âmbito da universidade pública e dar publicidade ao esforço do pesquisador. Entretanto, caso não seja do interesse do autor manter o documento online, pedimos compreensão em relação à iniciativa e o contato pelo e-mail bibfea@usp.br para que possamos tomar as providências cabíveis (remoção da tese ou dissertação da BDTD). 


$$
\text { Universidade de São Paulo }
$$

Faculdade de Economia, Administração e Contabilidade Departamento de Contabilidade e Atuária

\section{A RELEVÂNCIA DA INFORMAÇÃO CONTÁBIL PARA O MERCADO DE CAPITAIS: O MODELO DE OHLSON APLICADO À BOVESPA}

Alexsandro Broedel Lopes

Orientador: Prof. Dr. Luiz Nelson Guedes de Carvalho 


\section{REITOR DA UNIVERSIDADE DE SĀO PAULO:}

Professor Doutor Jacques Markowitch

DIRETOR DA FACULDADE DE ECONOMIA, ADMINISTRAÇĀO E CONTABILIDADE:

Professor Doutor Eliseu Martins

CHEFE DO DEPARTAMENTO DE CONTABILIDADE E ATUÁRIA:

Professor Doutor Reinaldo Guerreiro 
Universidade de São Paulo

Faculdade de Economia, Administração e Contabilidade

Departamento de Contabilidade e Atuária

\section{A RELEVÂNCIA DA INFORMAÇÃO CONTÁBIL PARA O MERCADO DE CAPITAIS: O MODELO DE OHLSON APLICADO À BOVESPA}

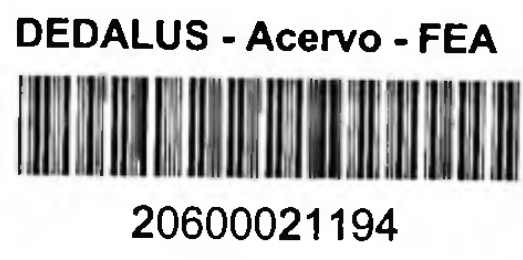

FEA - USP-SBO

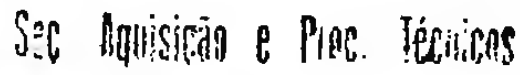

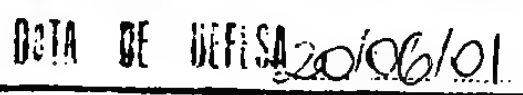

\section{Alexsandro Broedel Lopes}

Tese apresentada ao Departamento de Contabilidade e Atuária para cumprimento das exigèncias para obtençāo do título de Doutor em Controladoria e Contabilidade pela Faculdade de Economia, Administração e Contabilidade da Universidade de São Paulo

\section{Orientador: Prof. Dr. Luiz Nelson Guedes de Carvalho}




\section{FICHA CATALOGRÁFICA}

Lopes. Alexsandro Broedel

A relevància da informaçăo contábil para o mercado de capitais: o modelo de Ohlson aplicado à Bovespa / Alexsandro Broedel Lopes. Såo Paulo: FEAUUSP, 2001.

$308 \mathrm{p}$.

Tese - Doutorado

Bibliografia

1. Contabilidade financeira 2. Mcrcado de capitais 3. Contabilometria I. Faculdade de Economia, Administraçđ̃o c Contabilidade da USP

$$
\text { CDD }-657.48
$$


à Luciane,

fonte de inspiraçāo 
"In the life of every person there comes a point when he realizes that out of all seemingly limitless possibilities of youth he has in fact become one actuality."

Henry Kissinger, 1949. 


\section{AGRADECIMENTOS}

Um trabalho desta natureza é fruto do esforço de alguns anos e do envolvimento de várias pessoas. A expectativa de alguma surpresa positiva nesta tese é resultado da minha interação com um grande número de amigos e mestres que ao longo do tempo formaram a minha identidade intelectual. Cabe sempre a opção de nāo mencionar nomes, na tentativa de nāo cometer injustiças com os não citados. Talvez como decorrência da personalidade que estes amigos ajudaram a formar, nāo vou me furtar a estabelecer a minha longa relaçāo de dividas impagáveis.

Agradeço ao Nelson a existència desta tese. $O$ incentivo e a enorme paciência que tenho recebido desde os anos do curso de graduaçāo são inimagináveis. $A$ sua cooperação para o estabelecimento da ponte São Paulo - Londres nos momentos finais do trabalho foi indispensável. Sem a atençāo especial que tenho recebido esta tese não seria possivel. Muito obrigado!

Agradeço ao Prof. Iran por este trabalho e por todos os outros que eu vier a fazer na minha carreira. Sem o apoio que recebi nos meus primeiros passos a minha carreira provavelmente não existiria.

Agradeço ao Prof. Eliseu que tem me dado grande apoio na minha formaçāo como acadèmico e servido sempre como modelo a ser seguido. A influēncia do Prof. Eliseu faz-se presente simplesmente no meu desejo de seguir a carreira que sigo hoje.

Os comentários, criticas, sugestōes e principalmente o apoio dos Profs. José Roberto Securato e Alexandre Assaf Neto contribuiram muito para a qualidade do trabalho. 
O apoio institucional da FIPECAFI foi fundamental para a viabilização dessa pesquisa.

Gostaria de agradecer especialmente ao Prof. John Board da London School of Economics and Political Science pelas críticas inteligentes, conversas amigáveis e apoio incondicional.

Agradeço também aos amigos e professores da London School of Economics and Political Science: Prof. Michael Bromwich, Prof. Peter Miller, David Borger e participantes no Ph.D. Students Seminar do Financial Markets Group.

Para o Seu Nivaldo e Dona Antonieta não cabem agradecimentos. A minha divida e admiração com meus pais vai além destes termos.

Finalmente, o apoio da minha esposa, Luciane, foi muito além daquilo que eu mereço. 


\section{RESUMO}

Esta tese analisa o papel da informação contábil para explicar o comportamento dos títulos na Bolsa de Valores de São Paulo (BOVESPA). Este trabalho adota uma abordagem econômica baseada em fundamentação empirica e positiva. $O$ modelo de Ohlson é usado como a estrutura teórica para: (i) comparar o papel dos resultados anormais futuros e dos dividendos para explicar o comportamento dos preços correntes, (ii) testar o poder explicativo do resultado e do patrimônio e (iii) avaliar as caracteristicas de conservadorismo e reconhecimento assimétrico da informaçāo contábil.

A amostra foi selecionada de açōes negociadas na BOVESPA no periodo de 1995-1999. Os resultados indicam que a informação contábil é mais significativa do que os dividendos para explicar os preços correntes e que os valores de patrimònio explicam grande parte do comportamento dos preços enquanto os resultados nāo parecem ser relevantes. Como esperado, a informaçāo contábil no Brasil nāo é tāo conservadora como em paises cuja legislaçāo é baseada em Lei comum. Esses resultados refletem o sistema de governança corporativo no Brasil: fortemente regulado, propriedade concentrada, estrutura baseada em proprietários e nāo em acionistas, informação contábil voltada para os reguladores e proprietários e não para os acionistas.

Este trabalho contribui para a literatura em contabilidade e economia financeira em várias formas. Inicialmente, é fornecida uma aplicação do modelo de Ohison para a realidade brasileira revelando evidências sobre o comportamento da informaçāo contábil e do preço dos títulos no Brasil que permaneceu sem documentação por um longo periodo. Esses resultados mostram que a informação contábil pode ser, e realmente $\dot{e}$, relevante em mercados emergentes bem como em mercados mais desenvolvidos, ao contrário do que a literatura tradicional sugere. Ao mostrar a maior relevância do patrimônio sobre o resultado (em oposição ao que é observado em mercados mais desenvolvidos) este trabalho sugere que a 
informaçāo contábil permanece relevante no Brasil com um foco diferente: a atenção dos investidores parece estar voltada para o patrimônio devido as suas implicaçōes legais no modelo de governança corporativo brasileiro. A característica de conservadorismo dos dados brasileiros sāo consistentes com os primeiros resultados e com a literatura de governança corporativa mostrando que uma ligaçāo entre a relevância da informaçāo contábil e a estrutura geral de governança corporativa é uma alternativa promissora de pesquisa.

Este trabalho é limitado pelo procedimento de seleção da amostra e dinàmica informacional sobre a qual o modelo de Ohlson é baseado. Direçōes futuras de pesquisa neste tópico incluem uma investigação mais profunda das caracteristicas da informaçāo contábil brasileira e sua inter-relaçāo com os preços negociados bem como um material mais analítico relacionado com modelos do papel da contabilidade em mercados incompletos e imperfeitos. 


\section{ABSTRACT}

This thesis analyse the role of accounting information to explain securities' behaviour in the São Paulo Stock Exchange (Bovespa). This work adopts a positive empirical-based economic approach. The Ohlson model is used as the theoretical framework to: (i) compare the role of future abnormal earnings and dividends in explaining current prices, (ii) test the explanatory power of earnings and book values and (iii) evaluate the conservative and asymmetric recognition features of accounting information.

The sample was selected from shares traded at BOVESPA over the 1995-1999 period. The results indicate that accounting information is more significant than dividends to explain current prices and that book values explain most of current prices whilst earnings seem not to be relevant. As expected, accounting information in Brazil is not as conservative as it is observed in common-law countries. Those results reflect the general corporate governance system in Brazil: strongly regulated, concentrated ownership, stakeholder rather than shareholder structure and financial information focused on regulators and stakeholders rather than the ordinary investor.

This work contributes to the financial accounting and financial economics literature in several ways. Initially, it provides an application of the Ohlson model to the Brazilian scenario giving some evidence on the behaviour of accounting information and securities' prices in Brazil which remained unnoticed for a long time. Those results show that accounting information can be, and actually is, relevant in emerging markets as well as in more developed ones, in opposition to what traditional literature suggests. By showing the wider relevance of book-values over earnings (in oposition to what is observed in more advanced markets) it suggests that accounting information remains relevant in Brazil with a different focus: investor's attention seems to be focused on book values due to its legal implications in the Brazilian corporate governance model. The conservative 
characteristic of Brazilian data is consistent with the first results and with corporate governance literature showing that a link between accounting information relevance and general corporate governance structure is a promissing venue in this field of inquiry.

This work is bounded by the sample selection procedure and the information dynamics upon which the Ohlson model is based. Future directions on research on this topic includes a further investigation of Brazilian financial accounting features and their interrelation with prices as well as more analytic material related to models of the accounting role in imperfect and incomplete markets. 
SUMÁRIO

Agradecimentos

Resumo

Abstract

I. INTRODUÇÃO, 1

1.1 Problema e hipóteses de trabalho, 8

1.2 Importància do Tópico, 10

1.3 Metodologia, 11

1.4 Limitaçōes, 15

1.5 Contribuiçōes Esperadas, 16

1.6 Organizaçāo do Trabalho, 17

II. A PERSPECTIVA DA INFORMAÇĀO, MENSURAÇĀO E O MODELO DE OHLSON, 19

2.1 A tradiçāo Normativa, 19

2.2 Surgimento e Disseminaçāo da Abordagem Positiva, 24

2.3 A Perspectiva da Informação, 31

2.4 Contabilidade como Mensuração, 39

2.50 Modelo de Ohlson, 49

2.6 Propriedades Esperadas da Informaçảo Contäbil dentro da Especificação de Ohlson, 70

III REVISÃO DA LITERATURA, 75

3.1 Informaçăo Contábil e Mercados Financeiros, 87

3.1.1 Conteúdo Informativo do Resultado, 88

3.1.2 Resultado, Fluxo de Caixa e Accruals, 91

3.1.3 Oportunidade (timeliness) do Resultado, 91

3.1.4 Conservadorismo, 92

3.1.5 Relevância do Patrimônio e do Patrimônio e Resultado, 94

3.1.6 Precificação de Componentes Discricionários e Não-Discricionários, 97 
3.1.7 Volatilidade do Resultado e Risco Sistemático, 98

3.1.8 Economia da Evidenciação, 98

3.2 Estudos a Respeito da Eficiência dos Mercados, 101

3.2.1 Previsibilidade dos Retomos, 101

3.2.2 Velocidade de Ajustamento do Preço ao Anúncio de Resultados, 101

3.2.3 Conteúdo Informativo dos Preços, 102

3.2.4 Avaliaçāo de Notas Explicativas e Outras formas de Evidenciação, 102

3.2.5Diferenças nos Métodos Contábeis e Preços, 102

3..2.6. Desvio Pós-Anúncio, 106

3.2.7 Lançamento de Opções e Resposta do Preço aos Resultados, 107

3.2.8 Conclusões Gerais da Literatura, 109

3.3 Informação Contábil em Mercados não desenvolvidos, 111

3.4 Informaçāo Contábil e Govemança Corporativa, 122

3.5 A Contabilidade no Mercado Brasileiro, 135

3.5.1 Caracteristicas estruturais da contabilidade financeira no Brasil, 135

3.5.2 Mercado de Capitais no Brasil , 140

IV HIPÓTESES DO TRABALHO, 150

4.1Mensuraçāo: Lucros e Dividendos, 154

4.2 Poder Explicativo das Variáveis Contábeis, 160

4.3 Reconhecimento Assimétrico e Conservadorismo, 162

4.5 Resultados Esperados, 165

4.5.1 Lucros e Dividendos, 167

4.5.2 Poder Explicativo dos Números Contábeis, 167

4.5.3 Reconhecimento Assimétrico e Conservadorismo, 167

V EVIDÊNCIAS EMPIRICAS, 169

5.1 Seleção da Amostra e Estatisitcas Descritivas, 169

5.2 Lucro vs. Dividendos, 175

5.3 Poder Explicativo das Variáveis Contábeis, 178

5.4 Reconhecimento Assimétrico e Conservadorismo, 181

5.5 Diagnóstico das Regressōes Utilizadas, 184 
5.6 Informações Fornecidas, Interpretaçăo e Extensão dos Resultados, 198

VI CONCLUSÕES E SUGESTÕES PARA FUTURAS PESQUISAS, 213

VII BIBLIOGRAFIA, 222

VIII ANEXOS, 265

8.1 O modelo Expandido de Feltham-Ohison, 266

8.2 Dados e Empresas Utilizados no Trabalho, 270 


\section{LISTA DE FIGURAS E GRÁFICOS}

FIGURA 1: Resposta do Preço à Informação Contábil, 5

FIGURA 2: Representação Esquemática das Abordagens à Pesquisa Contábil, 30

FIGURA 3: Fluxo de Caixa na Presença de Incerteza, 46

FIGURA 4: Preço de Mercado e Preço Ideal do Ponto de Vista da informaçāo, 111

FIGURA 5: Performance do Brasil em Várias Classificaçōes de Risco, 146

GRÁFICO 1: Estabilidade dos Coeficientes das Regressōes do Grupo 'Poder Explicativo das Variáveis Contábeis', 196

GRÁFICO 2: Estabilidade dos Coeficientes das Regressōes do Grupo 'Lucro vs. Dividendos', 196

GRÁFICO 3: Estabilidade dos Coeficientes das Regressōes do Grupo 'Reconhecimento e Conservadorismo', 197

GRÁFICO 4: Evolução do Poder Explicativo do Patrimònio e do Lucro e Patrimònio, 199

GRÁFICO 5: Relaçāo Entre o İndice PatrimònioNalor de Mercado (BTM) e o Coeficiente de Reconhecimento Assimétrico $\left(\Psi_{3}\right), 200$ 


\section{INTRODUÇĀO}

Desde os desenvolvimentos teóricos ocorridos na década de 50, que lançaram a base para a moderna teoria financeira, o papel da informação nos mercados de capitais tem sido uma das áreas mais estudadas em finanças. Conceitos como risco, retorno, otimização, imunizaçāo, precificação de ativos, em um primeiro momento, e precificação de opçōes e outros derivativos, seguidamente, passaram a ser formalizados e fazer parte da teoria econômica moderna'. A pesquisa em contabilidade financeira do final dos anos 60 (BALL e BROWN, 1968 e BEAVER, 1968) começou a incorporar esses desenvolvimentos e a pesquisa em mercado de capitais (financial accounting capital markets based research) tornou-se uma das áreas mais proficuas na academia contábil internacional (WATTS e ZIMMERMAN, 1986:12). Muitos modelos foram desenvolvidos e técnicas econométricas e estatisticas foram utilizadas sob o paradigma positivo do estabelecimento de hipóteses, derivadas da teoria, seguidas do teste empírico das mesmas com vistas à verificaçāo de como a realidade se adequa ao estabelecido pela teoria (WATTS e ZIMMERMAN, 1986). A maior parte desses trabalhos tem sido realizada na tentativa de estudar o impacto da divulgaçāo de informaçōes contábeis no comportamento dos ativos em mercados financeiros, como documenta o trabalho de BROWN (1996).

Esses eventos representam uma grande mudança no paradigma de pesquisa existente na primeira metade do século vinte na academia contábil. A pesquisa realizada ate então, de caráter extremamente normativo, preocupava-se principalmente com a avaliaçāo de práticas contábeis de acordo com padrōes teóricos daquilo que se considerava como ideal. O "ideal" normalmente era baseado em conceitos económicos de lucro e riqueza. Em 1940, o trabalho clássico de PATON e LITTLETON (An Introduction to Corporate Accounting

\footnotetext{
${ }^{1}$ O livro Capital Ideas de Peter Bernstein é uma excelente descrição desses desenvolvimentos
} 
Standards), por exemplo, consolidou a idéia de que a contabilidade realizada dentro do princípio da competência e respeitando a confrontação da receita com a despesa seria o método mais adequado para se atingir um modelo de informação mais próximo do "ideal" econômico ${ }^{2}$.

A tradição normativa começou a ser substituida pela abordagem da informação (information approach) que, de acordo com alguns autores, representou uma verdadeira "revoluçāo" na pesquisa em ciências contábeis (BEAVER, 1998). Como pode ser visto com maiores detalhes no próximo capítulo, essa abordagem rompe com a visão da contabilidade como mensuração e inaugura o estudo desta como informaçāo disponivel aos usuários. Esse information approach foi fortemente influenciado por dois desenvolvimentos da economia financeira (financial economics): o modelo de precificação de ativos financeiros (Capital Asset Pricing Model, CAPM) e a hipótese dos mercados eficientes (eficient market hypothesis, EMH). Esses dois conceitos (modelos) forneceram a base para que pesquisadores pudessem verificar como o mercado reage à informaçāo emanada da contabilidade e também para verificar quão eficiente é o mercado em termos da informaçāo contábil (DYCKMAN e MORSE, 1986).

Basicamente, uma revisão detalhada da literatura é fornecida no capitulo 3, duas direçōes gerais foram utilizadas dentro do paradigma da informaçāo (FOSTER, 1986). A primeira tentando verificar a relevância da informaçāo fornecida pela contabilidade para investidores e outros usuários dentro do conceito de que a contabilidade compete com outras fontes de informação tendo que ser avaliada para que se possa verificar sua real utilidade para a sociedade. Dentro dessa perspectiva, padrōes contábeis e outros aspectos da regulamentação podem ser avaliados empiricamente. A segunda abordagem procura investigar a eficiència relativa dos mercados em termos do conjunto de informaçōes contábeis.

\footnotetext{
${ }^{2}$ Uma descrição mais adequada dessa transiçăo é formecida no próximo capitulo.
} 
Essas duas direçōes são extremamente correlacionadas e complementam-se. Seguindo a hipótese da eficiência na sua forma semi-forte (a mais utilizada em estudos empiricos de acordo com CAMPBELL et all (1997:20-22) um mercado pode ser dito eficiente se os preços existentes nesse mercado refletem todo o conjunto de informaçōes públicas passadas e presentes de uma forma que é impossivel a realização de qualquer tipo de lucro anormal (acima da remuneração pelo risco do título) usando esse conjunto de informações (CAMPBELL et all, 1997:20-22). Aceitando a forma semi-forte, os preços no mercado devem refletir toda a informaçāo disponivel imediatamente, eliminando qualquer oportunidade para resultados anormais. Essas consideraçöes levantam duas questōes fundamentais para a contabilidade: (i) será a contabilidade relevante para investidores no mercado financeiro? (ii) será o mercado financeiro eficiente com respeito à informaçāo contábil?

Essas duas questōes tem sido estudadas extensivamente nos últimos 30 anos. Segundo BEAVER (1998:90) algumas conclusöes importantes podem ser resumidas a partir dos trabalhos empiricos realizados nesse periodo:

1. existe uma forte correlação positiva entre variaçōes nos preços de açōes de empresas negociadas em bolsas de valores e a respectiva variaçäo no lucro contábil das mesmas dentro do mesmo periodo;

2. essa relação não ocorre na base de um para um (1:1). O mercado reage como se parte da flutuação no lucro das empresas fosse devida a aspectos transitórios e nāo permanentes. Esses aspectos transitórios não impactam a avaliaçāo da empresa e sua flutuaçāo de preços;

3. os preços das açōes comportam-se como se os investidores reagissem a diferenças entre os métodos e práticas contábeis das empresas; 
4. as flutuações de preço parecem considerar tanto o componente fluxo de caixa como o componente accrual do lucro;

5. os preços das açōes parecem antecipar o comportamento do lucro devido a fontes de informação mais rápidas do que a contabilidade. A idéia é que os preços refletem o conjunto de informações disponiveis ao mercado mais rapidamente do que a contabilidade (delayed recognition);

6. esse "reconhecimento atrasado" ocorre tanto para o lucro como para o patrimônio;

7. o preço das açōes pode ser usado para prever o lucro das empresas correspondentes. Essa caracteristica é normalmente chamada de information content of prices;

8. os preços das açōes comportam-se como se houvesse reconhecimento assimétrico de informações econômicas pela contabilidade. Essa caracteristica é presente nas estruturas conceituais da contabilidade em vários paises e é conhecida como conservadorismo;

9. o patrimônio da empresa, bem como o lucro, parecer ser importante para explicar o comportamento dos preços das açōes correspondentes;

10. evidenciação de notas explicativas e outras informações fora do balanço (off-balance sheet) são percebidas pelo mercado de acordo com a sofisticaçāo do mesmo. Assim mercados sofisticados tendem a avaliar mais adequadamente notas explicativas, por exemplo, do que os menos sofisticados ${ }^{3}$;

\footnotetext{
${ }^{3}$ Essa constatação é melhor entendida quando se considera a complexidade de algumas evidenciaçðes como instrumentos financeiros e beneficios a empregados.
} 
11. componentes discricionários (dependem de julgamento do administrador da empresa ou contador) são avaliados diferentemente de componentes não discricionários. Um exemplo de componente discricionário é a escolha do método de depreciaçăo. Um valor não discricionário é o montante de recursos em caixa ou o número de açōes emitidas pela empresa. Essa evidência é interpretada como se os administradores usassem esses componentes discricionários para sinalizar informações ao mercado;

12. medidas de risco sistemático nos preços são fortemente correlacionadas com medidas de risco sistemático no lucro contábil

Esse conjunto de evidências parece indicar que a contabilidade é relevante para investidores de mercado de capitais e que o mercado é eficiente com respeito à informaçăo contábil. Assim, com base nessas constataçōes, a seguinte tabela pode ser apresentada para ilustrar a relaçāo entre a relevància da informação contábil e a eficiência do mercado em termos de comportamento dos preços:

FIGURA 1 - Resposta do Preço à Informação Contábil

\begin{tabular}{|c|c|c|}
\hline $\begin{array}{c}\text { Eficiência } \\
\text { Dón Mercado } \\
\text { Contábil }\end{array}$ & Mercado Eficiente & Mercado Não Eficiente \\
\hline Relevante & $\begin{array}{c}\text { A resposta é rápida e imediata. 0 } \\
\text { mercado é capaz de avaliar notas } \\
\text { explicativas e outras evidenciaçōes } \\
\text { complexas (derivativos, pensões etc) }\end{array}$ & $\begin{array}{c}\text { A resposta não é rápida. Os } \\
\text { mercados não avaliam a } \\
\text { informação e não são capazes } \\
\text { de interpretar evidenciações } \\
\text { mais complexas }\end{array}$ \\
\hline Irrelevante & Sem reação & Inconsistente \\
\hline
\end{tabular}


A tabela acima é uma simplificação com o objetivo de ilustrar qual comportamento é esperado do mercado em relação à informação emanada da contabilidade com base na literatura e nas evidências empíricas. É claro que os niveis de eficiència não são absolutos como apresentados acima. Seguindo a hipótese dos mercados eficientes, informaçōes nāo relevantes não devem impactar os preços. No entanto, se a informação é relevante o impacto nos preços dependerá das características do mercado em termos de eficiência e de governança corporativa (BALL et all, 2000).

Apesar dessas constataçōes serem muito comuns e representarem a linha principal (mainstream) da pesquisa em contabilidade financeira (BEAVER, 1998) pouca ou nenhuma pesquisa empírica tem sido feita com o sentido de verificar tal comportamento em mercados menos desenvolvidos e emergentes. Honrosas exceçōes existem, como os trabalhos do Prof. FAMÁ (1998: 114-127; 2000: 10-21) que referem-se ao papel de indicadores contábeis na gestão financeira das empresas, do Prof. SANVICENTE (1982) investigando a precificação de bonds, do Prof. ASSAF NETO (1999; 1983) relacionando a informaçāo contábil com a gestão de valor e da projeçāo de resultados. Outros trabalhos como os de LEITE (1990), SPARANZINI (1994) e KERR (1988) investigam o nivel geral de eficiência do mercado de capitais brasileiro. Tais trabalhos, no entanto, não investigam diretamente (empiricamente) o papel da contabilidade como fornecedora de informaçōes para o mercado de capitais brasileiro. Como pode ser visto no capitulo 3 a maioria absoluta dos trabalhos nessa arena sāo realizados em mercados considerados desenvolvidos (principalmente Estados Unidos e Reino Unido) e evidências a respeito de mercados menos desenvolvidos, especialmente na América Latina, são praticamente inexistentes.

Inicialmente, existe um problema epistemológico de definição entre mercados emergentes e desenvolvidos. O International Finance Corporation (IFC, 1996:2) usa o termo emergente para "any market in a developing economy, with the implication that all have potential to development". A descriçōes pouco 
esclarecedoras como esta seguem-se outras como SHAPIRO (1998: 468) que inclui todos os países do mundo à exceção dos Estados Unidos, Canadá, Japão, Inglaterra e dos componentes da Europa Ocidental. Uma abordagem mais técnica é fornecida por KUMAR e TSETSEKOS (1999:19) que aceitam a classificação fornecida acima, mas apresentam duas características fundamentais desses mercados. A primeira relaciona-se aos atributos referentes à disponibilidade de informaçōes e a questōes acerca da microestrutura dos mesmos. Nesse campo, o fluxo de informaçōes para os participantes é considerado inadequado em mercados emergentes devido a problemas microestruturais. A segunda relacionase a aspectos institucionais como a estrutura tributária, corpo legal, etc. Devido a esses aspectos, é esperado que a eficiència nos mercados emergentes seja bastante reduzida.

Essas conclusōes acerca dos mercados emergentes estendem-se aos aspectos contábeis (KUMAR E TSETSEKOS, 1999). Tomando-se como base essas características informacionais, é esperado que mercados emergentes sejam pouco eficientes em termos de informaçōes contábeis (BEAVER, 1998) e que essas informaçōes sejam pouco relevantes para os investidores nesses mercados com base nas caracteristicas da regulamentaçăo contábil nesses paises e nos mecanismos de governança existentes. Essas consideraçōes, apesar do apelo intuitivo nāo possuem fundamentação empirica. Pode-se afirmar que existe uma grande lacuna na literatura contábil relacionada com evidèncias empiricas em mercados menos desenvolvidos.

Essa deficiència possui grandes implicaçōes para o entendimento do papel da contabilidade como fornecedora de informaçōes para o processo de tomada de decisōes no contexto de mercado de capitais emergentes ${ }^{4}$. Devido às

\footnotetext{
1 No entanto, como ANG (1991) comenta, evidências acerca do comportamento dos mercados menos desenvolvidos fornecem importantes contribuiçðes para o entendimento dos mercado mais sofisticados. Isso é possivel devido às oportunidades de experimentos em condiçðes nåo facilmente encontradas nos mercados mais ricos, como é o caso da hiperinflaçăo, risco sistêmico, e outros. Do ponto de vista teórico, mercados emergentes podem servir de laboratórios para o teste de teorias cstabelecidas fornecendo insights importantes para o desenvolvimento geral da economia financeira (inancial economics) ou da contabilidade.
} 
caracteristicas desses mercados (alta volatilidade, inflação, instabilidade política e econômica, etc), a reação dos investidores pode ser completamente diferente daquela esperada pela teoria. A perda de relevância da contabilidade em mercados emergentes devido aos aspectos de ineficiência dos mesmos poder ser contrabalançada pela maior importância da contabilidade relativamente a outras fontes de informação nesses mercados, por exemplo. Dessa forma, a contabilidade pode possuir um comportamento bem diferente daquele esperado segundo a literatura corrente. É dentro desse contexto que este trabalho se insere.

\subsection{Problema e hipóteses do trabalho}

Dentro do contexto da relevância da contabilidade como fornecedora de informaçōes para os usuários em mercados de capitais, este trabalho pretende analisar o seguinte problema:

\section{Qual a relevância da contabilidade para explicar o comportamento de preços das açōes negociadas na Bolsa de Valores de São Paulo (BOVESPA)?}

Verifica-se que a questāo de pesquisa nāo envolve a prova ou refutação de nenhum modelo especifico. Procura-se no trabalho a resposta da pergunta acima sem que existam definiçōes pré-concebidas do resultado que deveria ser encontrado. Nas seçōes 2.6 e 4.5 as propriedades esperadas da informação contábil sāo levantadas com base na teoria existente. A verificação da viabilidade empirica dessas expectativas faz parte do escopo do trabalho. Acredita-se que com essa visão mais "livre" pode-se limitar o viès presente em qualquer investigação cientifica.

Essa pergunta de caráter geral precisa ser decomposta em hipóteses mais práticas para que possam ser tratadas e testadas estatisticamente. Conforme a revisão da literatura no capitulo 3 demonstra, essa questāo geral pode ser dividida 
em questões mais especificas que, analisadas juntamente, podem fornecer uma resposta adequada para o problema. Essas questões são as seguintes:

a) baseado em um modelo de avaliação, compara-se o poder explicativo dos resultados contábeis futuros com o poder explicativo dos dividendos futuros. Dentro dessa questāo está a comparação entre a importância do lucro contábil em relação aos dividendos que são os principais "concorrentes" teóricos das variáveis contábeis em termos de explicação do preço das açōes das empresas;

b) baseado nesse modelo de avaliação compara-se o poder explicativo dos resultados contábeis e do patrimonnio em termos do preço atual das empresas. Nesse caso avalia-se o poder explicativo da contabilidade em concorrència com todo o conjunto de informações a disposição do mercado;

c) avalia-se a questão do reconhecimento assimétrico de informaçōes econômicas pela contabilidade. Nessa seçāo verifica-se como o lucro contábil incorpora o resultado econômico (normalmente definido como variaçāo no preço das açōes negociadas em bolsas de valores) e como o conservadorismo impacta o resultado contábil ${ }^{5}$. Assim, verifica-se como a contabilidade reflete o comportamento das variáveis econômicas subjacentes.

Com base nessas três questōes as hipóteses do trabalho são as seguintes:

$H_{0,}$ : a avaliação baseada em resultados contábeis futuros é tão relevante quanto aquela baseada em dividendos futuros.

\footnotetext{
${ }^{5} \mathrm{O}$ conservadorismo induz ao reconhecimento assimétrico do resultado econômico pelo resultado contabil. Perdas săo reconhecidas mais rapidamente do que ganhos. Exemplo desse tipo de procedimento é a regra de avaliaça de estoques que preconiza que deve ser utilizado o valor do custo ou mercado, dos dois o menor. Nesse caso uma empresa que tivesse o valor de seus estoques aumentado pelo mercado năo poderia reconhecer tal aumento, ficando limitada ao menor valor entre o custo e a avaliaçăo do mercado. Por outro
} 


\begin{abstract}
$H_{0 b}$ : preços correntes podem ser explicados por variáveis contábeis (lucro e patrimônio) com coeficientes estatisticamente significantes.
\end{abstract}

\title{
$H_{o c}$ : o resultado contábil incorpora significativamente o resultado econômico.
}

As seçōes seguintes apresentam como essas hipóteses serão testadas e as bases para a confecção das conclusōes do trabalho. $O$ trabalho não pretende resolver a lacuna existente em termos gerais relacionados aos mercados emergentes. $O$ foco do trabalho restringe-se ao Brasil.

\subsection{Importância do Tópico}

O papel da informação contábil nos mercados financeiros é uma das áreas mais estudadas em contabilidade. O mercado financeiro, de uma forma geral, é um dos maiores usuários da informação contábil por intermédio de analistas, corretoras, investidores institucionais e individuais, bancos de investimentos, etc. Esse cenário fornece um "laboratório" para o teste do papel da contabilidade e de como essas informaçōes interagem com os participantes desse mercado. Teorias podem ser testadas e a tradicional abordagem normativa pode ser abandonada, pelo menos nesse nivel. Por outro lado, com a internacionalização dos mercados financeiros e a importància desses para o desenvolvimento econômico, aumenta a demanda para maiores estudos relacionados ao entendimento do papel da contabilidade. Somente o entendimento desse papel pode orientar açōes futuras no sentido de melhorar o conteúdo informativo da informaçăo emanada pela contabilidade. 
Conforme documenta BALL et all (2000), a contabilidade sofre influências do modelo de governança corporativa adotado nacionalmente. No entanto, conforme apresenta BUSHMAN et all (2000), o modelo contábil adotado nacionalmente e as escolhas individuais de métodos contábeis feitos pelas empresas impactam as açōes de governança tomadas por essas empresas. Segundo BUSHMAN et all (2000), a contabilidade funciona como um mecanismo de redução de assimetria de informação e de conflitos de forma que modelos contábeis mais "fracos" fazem com que as empresas adotem outros mecanismos de governança corporativa para controlar as açōes dos administradores que nāo seriam necessários com modelos contábeis mais informativos. Nesse sentido, verifica-se quão ampla é a influência da qualidade dos padrōes contábeis nos mecanismos de gestão e controle das empresas por acionistas e outros interessados no desempenho da empresa.

A aplicação desse estudo ao caso brasileiro é importante para a redução da lacuna na literatura internacional a respeito do papel da contabilidade em mercados menos desenvolvidos. As conclusōes do trabalho também podem ser importantes para a avaliação do real papel da contabilidade no mercado brasileiro fornecendo informaçōes para a formulação de políticas contábeis pelos órgãos reguladores nacionais.

\subsection{Metodologia}

De uma forma geral, a metodologia empregada nesse trabalho pode ser classificada como empirico-analítca. Segundo MARTINS (1994:27)

“...são abordagens que apresentam em comum a utilização de técnicas de coleta, tratamento e análise de dados marcadamente quantitativas. Privilegiam estudos práticos. Suas propostas têm caráter técnico, restaurador e incrementalista. Tem forte preocupação com a relação causal entre as variáveis. A validação da prova científica é obtida 
através de testes de instrumentos, graus de significância e sistematização das definições operacionais".

Uma característica marcante do trabalho é a preocupação com a fundamentação teórica dos resultados empíricos apresentados. Essa abordagem deve-se à crença de que resultados empíricos sem adequada fundamentação conceitual tornam-se estéreis. Assim a tradiçăo positiva é utilizada dentro de sua amplitude como comentam WATTS e ZIMMERMAN (1986: 9-10):

"A theory consists of two parts: the assumptions, including the definitions of variables and the logic that relates them, and the set of substantive hypotheses. The assumptions, definitions, and logic are used to organize, analize, and understand the empirical phenomena of interest, while the hypotheses are the predictions generated from the analysis.

The development of a theory begins with the researcher thinking af an explanation for some phenomena. For example, an explanation for the use of LIFO or FIFO might be that managers chooses the method thar minimizes the tax liability.

Whether he spells it out formally or not, the researcher is making certain assumptions. In our example, he is assuming that the manager's objective is to minimize the present value of taxes and maximize the value of the firm. From the assumptions, the researcher explicitly or implicitly derives implications that can be empirically tested. For example, our researcher might derive the conditions under which the manager will choose LIFO or FIFO. Given some further assumptions, our researcher may show that the choice depends on the behaviour of the prices of firm's products and prices of material inputs. This provides an hypothesized relation between the behaviour 
of those prices and the LIFO/FIFO choice. After gathering data on those prices and the firms' inventory methods, the researcher can test the hypothesis.

The assumptions the researcher makes may be very simplistic. The logic employed may or may not take the form of math; the asscumptions, logic, and hypothesis may not even be spelled out in detail in the paper. However the researcher must implicitly take those steps before conducting any empirical work. The reason is that he must have an hypothesis and theory to collect the data. Without an hypothesis, the researcher does not know which facts or data to investigate"

Assim, a estrutura geral do trabalho está baseada no modelo de avaliação de OHLSON (1995) que será descrito no capitulo 2. A primeira hipótese será testada com base na regressão do preço das açōes da empresa (variável dependente) em relação a dois conjuntos de variáveis: (i) patrimonnio e lucros anormais futuros e (ii) dividendos futuros conforme sugere BERNARD (1995:437). As regressōes serāo comparadas em termos de significância dos coeficientes e poder explicativo. Não existe uma regra rigida para julgar o poder explicativo das variáveis contábeis. Os valores encontrados serāo comparados com aqueles tradicionalmente reportados pela literatura. A hipótese $H_{0 b}$ também será julgada em referência a significància dos coeficientes encontrados na regressão do preço das açōes da empresa em relação ao lucro e patrimônio do periodo como propōe Collins et all (1997). O poder explicativo será comparado com os números reportados na literatura para que se possa fazer a análise comparativa entre os resultados encontrados no Brasil e àqueles obtidos em mercados mais desenvolvidos. A terceira hipótese será julgada em termos da significancia dos coeficientes encontrados na regressão do resultado contábil do periodo (variável dependente) em relação ao resultado econômico do periodo com variáveis dummy representando resultados

\footnotetext{
${ }^{6}$ Grifo adicionado por este autor.
} 
positivos e negativos como é proposto por BASU (1997:3) e BALL et all (2000:20). Conforme visto, o critério de julgamento será constituido pelos próprios coeficientes da regressão e o pelo poder explicativo da mesmas. Na seçāo 5.5 , que trata do diagnóstico das regressōes utilizadas, a questão da interpretação dos resultados obtidos será analisada em maiores detalhes.

Como é visto no capítulo 3, o teste da importância da informação contábil para - mercado financeiro pode ser feito utilizando-se outras abordagens. Cabe ressaltar as razōes que levaram a escolha da abordagem particular adotada neste trabalho. Pode-se identificar as seguintes abordagens para a análise desse particular problema: (i) verificaçāo do conteúdo informativo dos preços como "antecipadores" da informação presente no lucro, (ii) verificação do conteúdo informativo do lucro por intermédio de event studies visando a identificação de reaçōes à publicação de resultados anormais dentro de um horizonte de tempo, (iii) verificaçāo da reaçāo do mercado a evidenciação de elementos especiais como derivativos e passivos atuariais em notas explicativas, (iv) verificaçāo da reaçāo dos preços à mudanças de métodos contábeis $e(v)$ verificação validade de estratégias de trading baseadas em informaçōes contábeis publicadas como forma de avaliar a eficiência do mercado. A abordagem (i) nāo é utilizada neste trabalho porque foge do objetivo do mesmo que é avaliar o papel da contabilidade no mercado acionário brasileiro e não o papel dos preços como 'antecipadores' da contabilidade. A segunda abordagem não foi considerada devido ao problema natural da hipótese conjunta de identificar o precificador correto para a definição do resultado anormal. As opçōes (iii) e (iv) sofrem da ausència de informaçōes adequadas e nāo contribuem diretamente para a questão central do trabalho. Em trabalhos futuros ambas podem ser testadas como hipóteses subsequentes aos resultados do presente trabalho. A quinta abordagem nāo é relevante uma vez que a eficiència do mercado brasileiro não está sendo avaliada a priori.

A opção escolhida para este trabalho, baseada no modelo de OHLSON (1995), deve-se principalmente à fundamentação teórica deste que fornece o arcabouço 
suficiente para que a contabilidade possa ser integrada em uma função de avaliação do valor da empresa, como poderá ser visto com maiores detalhes no capitulo 2. Assim, tem-se a fundamentação teórica suficiente para que os estudos empíricos seguintes possam ser realizados. Dessa forma, aplica-se uma abordagem empírico-positiva dentro da visão de WATTS and ZIMMERMAN (1986:12): escolha do modelo, seleção das variáveis adequadas, seleção da amostra, testes e conclusões baseadas nos resultados obtidos.

\subsection{Limitaçōes}

Abaixo estão sumarizadas as principais limitaçōes do trabalho juntamente com comentários sobre o impacto das mesmas na interpretação dos resultados encontrados:

a) modelo de avaliação: todas as limitaçōes inerentes ao modelo de OHLSON(1995) utilizado no trabalho aplicam-se à tese de uma forma ampla. O capítulo seguinte apresenta os motivos detalhados para utilizaçāo do modelo e as implicaçōes para o trabalho;

b) seleçăo da amostra: as conclusōes obtidas ficam, de certa forma, restritas a amostra utilizada. Generalizações devem ser feitas cuidadosamente. Esse ponto é comum a trabalhos empíricos;

c) paradigma utilizado: a contabilidade possui outros papéis além daqueles captados pelo modelo empregado;

d) viés de sobrevivència (survivorship bias): devido às caracteristicas de seleção da amostra (mesmo número de empresas ao longo do periodo analisado) existe a hipótese de seleção viesada de empresas com um determinado tipo de característica. Este problema possui importância menor na medida que a seleção da amostra não usou nenhum critério especial a não ser a própria 
disponibilidade de dados. Da mesma forma, não pretende-se a prova ou aceitação de um dado modelo neste trabalho;

e) o último aspecto abordado acima merece destaque especial. Neste trabalho não se pretende a prova especifica do modelo de OHLSON ou de qualquer outra abordagem. A idéia principal do trabalho é investigar, da forma mais cientifica possivel, o comportamento dos preços em relação às informaçōes contábeis no mercado brasileiro, sem pré-concepções sobre os resultados a serem encontrados.

\subsection{Contribuiçōes Esperadas}

A contribuição deste trabalho reside no fornecimento de evidèncias empiricas sobre o comportamento do mercado financeiro brasileiro em termos de informaçōes contäbeis. Assim, cobre-se uma lacuna da literatura internacional sobre $o$ assunto possibilitando o melhor entendimento do papel da contabilidade em mercados financeiros menos desenvolvidos. É importante clarificar que a contribuição do trabalho está fundamentada na aplicaçāo do modelo de OHLSON (1995) ao mercado de capitais brasileiro. Residualmente, contribui-se para a teoria da contabilidade na medida que se aumenta o entendimento da relaçāo entre a informaçāo contábil e o mercado financeiro. Espera-se que o entendimento e a análise do papel da contabilidade no mercado financeiro brasileiro possa ser baseado em figuras empiricas com menor grau de julgamento e normativismo.

Beneficiam-se deste trabalho estudantes, com maior entendimento do papel da contabilidade, executivos financeiros e analistas, que poderão utilizar melhor as informaçōes disponiveis; pesquisadores, que terāo uma base inicial para a continuação das pesquisas no assunto e, principalmente, a profissão contábil brasileira que possuirá maiores evidèncias do seu papel na sociedade, dentro do contexto do mercado financeiro. 
Pesquisadores de contabilidade financeira e internacional devem encontrar subsidios suficientes nesse trabalho para a continuidade desse tipo de estudo no Brasil, por intermédio das sugestōes para pesquisas futuras.

O trabalho é pioneiro no cenário contábil brasileiro devido ao método utilizado. Inicialmente, é exposto um modelo analítico que orienta o restante do trabalho. As evidèncias empiricas encontradas seguidamente estão contextualizadas teoricamente dentro do modelo apresentado. Dessa forma, os resultados não sāo apresentados dentro de um vazio conceitual ou sobre premissas normativas. No entendimento apresentado nesta tese, evidências empiricas são melhores avaliadas quando motivadas e justificadas por um corpo teórico analítico estabelecido.

\subsection{Organização do Trabalho}

O restante do trabalho está organizado conforme apresentado a seguir. 0 capitulo 2 apresenta a perspectiva da informação na contabilidade e o ponto de ruptura com a contabilidade normativa bem como o modelo de Ohlson que procura resgatar a integraçāo entre os números contábeis e a realidade econômica subjacente dentro de uma estrutura de avaliaçāo. A importância desse capitulo reside na apresentação dessa metodologia pouco conhecida e empregada na academia contábil brasileira. Essa apresentação é fundamental para que as aplicaçōes subsequentes possam ser contextualizadas dentro da evoluçāo teórica e conceitual da contabilidade. O capitulo 3 apresenta uma revisão detalhada da pesquisa empirico-positiva em contabilidade financeira. Ao fornecer uma visão do estado da arte da pesquisa na área, esse capitulo contextualiza a contribuição do trabalho ao apresentar as principais linhas de estudo e suas limitaçōes e lacunas. O capitulo 4 apresenta o detalhamento das hipóteses por intermédio da apresentação dos modelos derivados do modelo de principal. 0 capitulo 5 detalha a seleção da amostra as estatisticas descritivas bem como os resultados 
encontrados na aplicação dos modelos. O capítulo final conclui e sugere algumas opçöes para pesquisas futuras. 


\section{INFORMATION APPROACH NA CONTABILIDADE}

A contabilidade é uma disciplina relativamente nova em termos acadèmicos, estabelecendo-se na maior parte dos paises ocidentais durante 0 século 20 (PREVITS e MERINO, 1998). No entanto, durante esse periodo, a contabilidade experimentou uma verdadeira revoluçāo nos métodos e técnicas de pesquisa, nas abordagens utilizadas e mesmo na própria natureza da investigaçāo realizada. De uma disciplina basicamente normativa, preocupada com recomendações a respeito de melhores práticas profissionais, a contabilidade transformou-se em uma disciplina mais 'científica' com o vasto emprego de modelagem econômica e fundamentaçăo estatistica. Como essa "revoluçāo" iniciou-se no final da década de 60, o que pode ser observado na pesquisa contábil atualmente é uma mistura do antigo e do novo formando uma idiossincrasia caracteristica (PANNOZO, 1997). Devido a essa situação e ao atual estágio de desenvolvimento da pesquisa contábil brasileira ${ }^{7}$, este capitulo introduz as principais transformações ocorridas na pesquisa em contabilidade financeira durante o século 20 com o objetivo de contextualizar o trabalho. Adicionalmente, 0 . modelo de OHLSON (1995), que é a base conceitual do trabalho, é introduzido e as implicaçōes de sua utilização são apresentadas.

\subsection{A tradiçāo Normativa}

A contabilidade, ao contrário de outras áreas acadèmicas como a sociologia, antropologia, economia e outras, estabeleceu-se academicamente ao longo da primeira metade do século 20 sob influência e como resposta às demandas da profissão (PREVITS e MERINO, 1998). Como resultado dessa influência muitos dos primeiros acadêmicos de destaque na contabilidade

\footnotetext{
7 Cabe ressaltar que năo se está fazendo nenhuma consideraçăo de valor acerca da "melhor" opçăo metodológica. Este capitulo tem somente o objetivo de apresentar claramente o "pano de fundo" da pesquisa realizada.
} 
moderna eram membros da profissão, sendo assim, fortemente ligados à problemática do exercício dessa. Como decorrência natural desse fenômeno, a pesquisa contábil estabeleceu-se inicialmente com caráter extremamente normativo e voltado à recomendação de práticas e procedimentos profissionais.

Essa visão da contabilidade que permeou a primeira metade do século $X X$ possuia duas metodologias básicas para derivar os padrōes contábeis que deveriam produzir os resultados esperados: (i) a primeira se referia a tentativa de inferir critérios advindos de definições genéricas como a de lucro econômico; nesse sentido os números contábeis deveriam ser produzidos dentro de critérios que se aproximam dessas definições gerais normalmente advindas da teoria econômica; (ii) a segunda referia-se a tentativa de estabelecer requisitos "ideais" para os valores contábeis e em seguida realizar uma comparação entre os valores realmente obtidos e aqueles ideais. $\mathrm{O}$ grande problema presente em ambas as abordagens está relacionado a ausência de critérios operacionais. Como pode ser inferido pelos tradicionais trabalhos de PATON (Accounting Theory, 1922). Canning (The Economics of Accountancy, 1929) e ALEXANDER (Five Monographs on Business Income, 1950) esses conceitos são impossiveis de serem verificados na prática fornecendo ampla margem para especulaçōes e discussōes normativas. Os trabalhos de EDWARDS e BELL (The Theory and Measurement of Business Income, 1961), CHAMBERS (Accounting Evaluation and Economic Behaviour, 1966) e STERLING (The Theory of the Measurement of Enterprise Income, 1970), apesar de mais elaborados do que os anteriores, também são icones dessa tradiçāo normativa baseada em conceitos econômicos.

A abordagem normativa pode ser visualizada na observação de recomendações contábeis advindas de órgãos reguladores e teóricos da contabilidade. A questāo do reconhecimento da receita fornece uma oportunidade para análise dessas recomendaçōes. Em muitas situaçōes não é claro como a receita de um dado projeto ou investimento deve ser reconhecida na contabilidade, o mesmo ocorrendo com algumas despesas e gastos como aqueles 
com pesquisa e desenvolvimento, por exemplo. Da mesma forma que o reconhecimento, o modelo de mensuração contábil também oferece exemplos de - recomendaçōes normativas. O FASB (FASB, 1997) no pronunciamento $\mathrm{N}^{0} 107$, Disclosure about fair value of financial instruments (parágrafos 39-41), afirma:

"The Board concluded that information about fair value of financial instruments meets the first objective of financial reporting stated in FASB Concepts Statement No 1, Objectives of Financial Reporting by Business Enterprises, that is, to provide information that is useful to present and potential investors, creditors, and others users in making rational investment, credit and similar decisions.

Fair value of financial instruments depict the market's assessment of the present value of net future cash flows directly or indirectly embodied in them, discounted to reflect both current interest rates and the market's assessment of the risk that the cash flows will not occur. Investors and creditors are interested in predicting the amount, timming, and uncertainty of future cash flows from the entity to them. Periodic information about the fair value of an entity's financial instruments under current conditions and expectations should help those users both making their own predictions and in confirming or correcting their earlier expectations

Information about fair values better enables investors, creditors, and other users to assess the consequences of an entity' investment and financing strategies, that is, to asses its performance. For example, information about fair value shows the effects of a decision to borrow using fixed-rate rather than floating-rate financial instruments or of a decision to invest on long-term rather than short-term instruments. Also, in a dynamic economy, information about fair value permits 
continuous reassessment of earlier decisions in light of current circunstances."

Esse pronunciamento é um exemplo clássico de recomendação baseada na abordagem normativa. O fair value é considerado como melhor medida para mensuração de instrumentos financeiros. Apesar de o pronunciamento citar a utilidade para o usuário como critério fundamental, nenhuma evidència é apresentada de que o fair value é realmente a medida mais útil. Nesse caso, o FASB apresenta a perspectiva da informaçāo como base para o pronunciamento, mas ao mesmo tempo, recomenda procedimentos extremamente normativos. Essas consideraçōes refletem perfeitamente os conceitos apresentados por WATTS e ZIMMERMAN (1979:273-305) no artigo The Demand and Supply of Accounting Theories: The Market for Excuses. Aplicando-se a perspectiva fornecida por esse artigo ao pronunciamento $N^{\circ} 107$ verifica-se que o FASB utiliza a perspectiva da informação como desculpa para a apresentação de um pronunciamento que nāo possui nenhuma relaçāo verificável com a tomada de decisão por investidores. Segundo o trabalho de WATTS e ZIMMERMAN (1979: 273-305) as abordagens teóricas na contabilidade sāo utilizadas para encobrir outros interesses que não estão, normalmente, relacionados com a melhor opçāo técnica.

A abordagem normativa não é privilégio de órgãos reguladores como o FASB. Muitos estudos acadêmicos feitos no passado, e mesmo hoje em dia, carregam fortemente o 'tom normativo'. Esse aspecto não é somente aplicado a questōes especificas e técnicas como a mensuração de instrumentos financeiros. Para muitos autores a própria estrutura geral da contabilidade pode ser avaliada segundo essa abordagem. MACVE (1997:35) é um bom exemplo:

"The role of a conceptual framework is to provide a strucuture for thinking about what is better accounting and financial reporting ${ }^{2}$. It

\footnotetext{
Negrito inserido por este autor.
} 
is a theoretical endeavour with the practical aim of clarifying the objectives of financial reporting, and how alternative practices are likely to help achieve those objectives. Whether as a company director, a chief accountant, an auditor or an accounting standard setter, one cannot make a rational choice of accounting procedures whithout some framework of principle. The purpose of the FASB project and other similar studies is to discover how much agreement there is about objectives and the means to those objectives."

Apesar da exposiçāo brilhante, de um dos maiores teóricos da contabilidade moderna, pode ver-se claramente que a estrutura conceitual básica da contabilidade, dentro da abordagem do Prof. RICHARD MACVE, passa necessariamente por definições normativas daquilo que a priori é melhor. Outros teóricos referem-se a normatização da contabilidade dentro dessa perspectiva. $O$ trabalho clássico de BAXTER (1979:25-40), por exemplo, afirma:

"We all welcomed standards when we first heard of them, and we all accept that they have great influence. They give us handy rules for our work. We believe that they raise the quality of accounts, make company reports more inteligible, and foster comparability; they dispel doubts, and-we hope-soon will bring harmony of principle. In a world made safe by enough standards, accounting will be plagued by few scandals, and our noisy defamers will have to hunt elsewhere for a quarry.

Apesar do tom irônico das observaçōes de BAXTER, percebe-se claramente que nāo há a preocupação de considerar-se o usuário na análise da regulamentação da contabilidade. Mesmo um clássico como DAVID HAWKINS (1986:5) da Harvard Business School argumenta: 
"Today corporations have considerable leeway in how they report their financial condition and results of operations. Despite recent progress in eliminating undesirable reporting practices, many areas remain in which alternative practices are equally acceptable for reporting essentially identical business situations."

Nessa afirmaçăo verifica-se claramente que o autor considera, a priori, como indesejáveis o tratamento de transaçōes idênticas de forma diferente. Esse é outro exemplo típico de afirmação de caráter normativo. Utilizando-se o ponto de vista econômico mais cuidadoso, tais práticas diferentes entre empresas podem, por exemplo, estar sinalizando informações importantes para o mercado. A idéia de que a padronização total da contabilidade é benéfica para os usuários é extremamente normativa e não é consistente com as evidências empiricas fornecidas mais recentemente.

Essa abordagem que dominou a pesquisa contábil durante muitos anos, e é ainda fortemente presente em alguns paises, forneceu elementos importantes para a delimitação da contabilidade moderna, suas caracteristicas e formas de atuaçāo. No entanto, a falta de rigor cientifico, pequena preocupaçāo com evidenciaçāo empirica e desenvolvimento de cièncias correlatas como economia e finanças, fizeram com que a pesquisa em contabilidade fosse lentamente absorvendo outras perspectivas, abordagens e métodos.

\subsection{Surgimento e Disseminaçāo da Abordagem Positiva}

No final dos anos 60 a ènfase da contabilidade, estabelecendo-se aqui uma referência clara à contabilidade norte-americana, começou a migrar da tradiçāo econòmica e normativa para uma perspectiva baseada na informaçāo, que ficou conhecida como information approach. Esta nova visāo dominou rapidamente a pesquisa acadèmica em contabilidade no mundo anglo-saxão (BROWN, 1996: 12) 
e o seu pilar fundamental foi estabelecido pelo FASB em 1978 no Statement of Financial Accounting Concepts No 1 que afirmou:

"Os relatórios financeiros devem fornecer informações que sejam úteis para os investidores atuais e futuros, credores e outros usuários na verificação dos montantes, periodicidade e incerteza relacionados aos seus recebimentos futuros de caixa... Uma vez que os fluxos de caixa dos investidores e dos credores estão relacionados aos fluxos de caixa da instituição, os relatórios financeiros devem fornecer informações para ajudar os investidores, credores e outros usuários a verificar os montantes, periodicidade e incerteza relativos aos fluxos futuros de caixa da entidade relacionada. ( $\rho$ viii)"

Assim, pode-se verificar que a ènfase das demonstraçōes financeiras mudou completamente de um modelo endógeno baseado em definiçōes e inferências a partir destas para um modelo baseado na utilidade da informaçăo para uma determinada finalidade tendo em vista um tipo de usuário. É importante ressaltar que o IASC (International Accounting Standards Committee) tambèm estabeleceu em sua estrutura conceitual (Conceptual Framework) uma visão da contabilidade sob o ponto de vista da informaçāo, como pode ser visto na estrutura conceitual do órgão (IASC, 1989: cap. 4)

Antes de prosseguir nessa exposição, é importante ressaltar que a perspectiva da informação é uma das facetas da abordagem positiva. Segundo WATTS e ZIMMERMAN (1986: 2):

"The objective of accounting theory is to explain and predict accounting practice. Our definition of accounting practice is broad. Because the development and nature of accounting is closely related to auditing, auditing practice is included as part of accounting practice. 
Explanation means providing reasons for observed practice. For example, an accounting theory should explain why certain firms use the last-in, first-out (LIFO) method of inventory rather than the first-in, first-out (FIFO) method.

Prediction of accounting practice means that the theory predicts unobserved accounting phenomena. Unobserved phenomena are not necessarily future phenomena; they include phenomena that have ocurred but on which systematic evidence has not been collected. For example, an accounting theory can provide hypotheses about the attributes of firms that use LIFO versus atributes of firms using FIFO. Such predictions can be tested using historical data on the attributes of firms using the two methods."

Como pode ser observado, dentro da abordagem positiva, a teoria contábil, e por consequencia a pesquisa, devem estar direcionadas a explicaçāo dos fenòmenos observados. Nesse sentido, não cabe avaliar qual a melhor contabilidade. Os motivos da escolha de um determinado procedimento contábil é que são importantes. $O$ completo entendimento do que é realizado na prática serve como base fundamental para a previsăo de comportamentos futuros. $\mathrm{Na}$ abordagem positiva, o fair value, por exemplo, nāo é bom ou ruim, desejável ou indesejável. A preocupação está focada no entendimento do porquê da utilização do método pelas empresas. A estrutura normativa nāo possui capacidade preditiva devido à ausência de preocupação com o entendimento das práticas existentes. Pesquisas normativas nāo se propõe a prever o que ocorrerá com a contabilização de um dado item; elas estāo, normalmente, direcionadas à avaliaçāo do tratamento dentro de critérios qualitativos.

A frustração inicial com a ausência de recomendaçōes dentro abordagem positiva é reconhecida por WATTS e ZIMMERMAN (1986: 6): 
"...after the securities acts the accounting literature became normative in the sense that it sought to prescribe the contents of accounting reports. For example, Chambers (1966) advocates current cash equivalents, and Edwards and Bell (1961) advocate current costs as the basis for the valuation of assets. Financial accounting texts also tend to adopt normative (i.e., prescriptive) positions.

By itself, theory, as we describe it, yields no prescriptions for accounting practice. It is concerned with explaining accounting practice. It is designed to explain and predict which firms will and which firms will not use a particular method of valuing assets, but it says nothing as to which method a firm should use. The situation is well described by Passmore (1953: 676):

Such a theory (a theory in social science) will have the limitations characteristic of the physical sciences. It will not tell us what we ought to do, any more than physics tell us wheter to build a bridge or to be content with a ferry."

Esses aspectos da abordagem positiva precisam ser clarificados inicialmente, devido ao papel destes no restante do trabalho. Seguindo essa visāo, esta tese nāo se preocupa em avaliar se a contabilidade no Brasil é boa ou ruim, ou se o lucro publicado é o número ideal. A realidade contábil brasileira é assumida como um dado do problema. A ambição do trabalho é o entendimento de como o mercado financeiro trabalha com essa informação e, esperançosamente, contribuir para a compreensão geral do papel da contabilidade na sociedade.

Além dos pontos apresentados, dois aspectos adicionais podem ser apresentados como justificativas para 0 abandono parcial da abordagem normativa: 
- os conceitos de resultado econômico, lucro econômico e demais definições gerais apresentadas são de difícil concepção teórica quando existem mercados imperfeitos ou incompletos para os ativos relacionados à operação da empresa. Cabe ressaltar que năo se está considerando tentativas meritórias de implementação do conceito de resultado econômico na contabilidade gerencial como pode ser visto em CATELLI (Controladoria, 1999) e GUERREIRO (Modelo Conceitual de Sistema de Informação de Gestão Econômica, 1989). Tais trabalhos não estão direcionados para a contabilidade financeira e suas peculiaridades. O cálculo do valor da empresa em mercados perfeitos e completos é facilitado uma vez que se conhecem todos os estados da natureza e o valor presente dos dividendos futuros torna-se um simples exercicio de álgebra. No entanto, quando se trabalha com mercados não tão perfeitos nenhum modelo apresenta-se como suficientemente adequado para resolver o problema. Dessa forma, as definiçōes contábeis derivadas de conceitos econômicos não podem ser aplicadas à realidade das organizaçōes;

- mesmo em situaçōes nas quais existem mercados perfeitos para a avaliaçāo dos ativos da empresa, os métodos para avaliaçāo e utilizaçāo dessas informaçōes podem ser diferentes e consequentemente produzindo resultados muito dispares.

Assim, a perspectiva da contabilidade ligada a informação produzida e não mais aos critérios técnicos estabelecidos de forma endógena começou a dominar a prática e a pesquisa em contabilidade. No entanto, apesar dessa mudança de perspectiva o FASB continuou a considerar as informaçōes contábeis produzidas por intermédio da competència e da confrontaçāo da receita com a despesa, por exemplo, como superiores àquelas produzidas somente pelo fluxo de caixa. Assim segundo o FASB ( 1978) no SFAC No 1: 
"as informações acerca dos resultados da empresa baseados na contabilidade por competência são um indicador melhor da capacidade presente e contínua da empresa de gerar fluxos de caixa quando comparados com informações limitadas aos aspectos financeiros dos recebimentos e pagamentos futuros de caixa. ( $p$ ix) ${ }^{n}$

Essa assertiva baseia-se na idéia de que a competência traz mais informaçōes para a contabilidade do que o regime de caixa. Essa conclusão é bastante lógica uma vez que o método de avaliaçäo de estoques reflete informaçōes sobre o giro do mesmo da mesma forma que o reconhecimento de despesas relacionadas a recebiveis incobráveis reflete a expectativa da administração quanto ao efetivo recebimento, por exemplo. A competència reflete, de uma forma ou de outra, algum conhecimento do futuro de modo a permitir aos administradores exercer um certo grau de autonomia no processo de reconhecimento contábil. Essa autonomia não seria possivel caso a contabilidade fosse mantida dentro do regime de caixa.

Essas constatações refletem uma nova visāo da contabilidade pelos órgãos reguladores. Uma visāo mais baseada no papel da informação para o usuário e nas reais necessidades do mesmo em termos de previsão de fluxos futuros de caixa, por exemplo. Dessa forma, o papel da informação contábil passou a ser analisado dentro do paradigma tradicional da economia clássica. A informaçāo contábil passou a ser vista como mais um produto (com algumas caracteristicas especiais) sendo analisada dentro de sua contribuiçäo para a utilidade dos agentes e firmas. A visão normativa de que a contabilidade possui valor a priori estava sendo abandonada.

Nessa nova visão o papel da contabilidade para a sociedade passou a ser visto de outra forma com respectiva alteração dos mecanismos e técnicas de pesquisa. Várias questōes puderam ser examinadas de forma positiva (WATTS e ZIMMERMAN, 1986) com estabelecimento de hipóteses advindas da teoria econômica e respectivo teste empírico das mesmas para verificação do real 
comportamento dos agentes econômicos frente à informação contábil. Exemplos dessas questōes sāo o papel da regulamentaçāo da prática profissional, como a contabilidade impacta o preço dos ativos no mercado financeiro, como a contabilidade pode ser utilizada para resolver problemas de agência entre proprietários e administradores. Apesar de várias abordagens serem utilizadas, dentro da pesquisa positiva a informaçāo contábil tem dois papéis básicos: informação e mensuração. A figura a seguir, adaptada de WHITE et all (1994:289) sumariza a discussão realizada acima.

FIGURA 2. Representação Esquemática das Abordagens da Pesquisa Contäbil

\begin{tabular}{|c|c|c|c|}
\hline Abordagem & $\begin{array}{c}\text { Elementos de } \\
\text { Análise }\end{array}$ & Foco da Pesquisa & Método \\
\hline $\begin{array}{c}\text { Teoria Clássica } \\
\text { (Normativa) }\end{array}$ & $\begin{array}{c}\text { Decisðes } \\
\text { Operacionais, de } \\
\text { financiamento e } \\
\text { investimento }\end{array}$ & $\begin{array}{l}\text { Descriçāo Contảbil do } \\
\text { Ideal Económico que nāo } \\
\text { e observável }\end{array}$ & $\begin{array}{l}\text { Proximidade Conceitual das } \\
\text { Normas Contábeis com os } \\
\text { conceitos econỏmicos sem } \\
\text { validaçäo empírica }\end{array}$ \\
\hline Teoria Positiva & $\begin{array}{l}\text { Decisסes } \\
\text { Operacionais, de } \\
\text { financiamento e } \\
\text { investimento }\end{array}$ & $\begin{array}{l}\text { Reaçăo do Mercado, } \\
\text { Remuneraçăo dos } \\
\text { Gestores, Ambiente } \\
\text { Regulatório e Outros }\end{array}$ & $\begin{array}{l}\text { Poder da Teoria de Explicar e } \\
\text { Prever os Eventos Estudados. } \\
\text { Desconsidera Outras Questōes } \\
\text { (historicas, sociológicas, etc) }\end{array}$ \\
\hline $\begin{array}{c}\text { Market-Based } \\
\text { Research }\end{array}$ & $\begin{array}{l}\text { Decisठ̄es } \\
\text { Operacionais, de } \\
\text { financiamento } \\
\text { investimento }\end{array}$ & $\begin{array}{c}\text { Informação e Reaçảo do } \\
\text { Mercado }\end{array}$ & $\begin{array}{l}\text { Significáncia da Reação do } \\
\text { Mercado às normas contábeis. O } \\
\text { mercado é o árbitro. }\end{array}$ \\
\hline
\end{tabular}

O quadro acima procura somente apresentar uma visão sucinta dos tópicos até aqui discutidos. A divisão entre teoria positiva e pesquisa baseada na reação do mercado tem finalidades somente explicativas uma vez que a abordagem mais comum é classificar ambas dentro da mesma base epistemológica. 


\subsection{A Perspectiva da informação}

O information approach ${ }^{9}$ (abordagem da informação) enxerga a contabilidade dentro do seu papel de fornecedora de informaçōes para os agentes económicos. Dentro dessa abordagem a contabilidade deve ser avaliada a partir de sua capacidade de fornecer informações que sejam úteis ao processo de decisāo dos usuários. Assim, torna-se fundamental o estabelecimento de duas condições básicas: (i) qual o processo de tomada de decisāo dos usuários e (ii) em qual ambiente (certeza e incerteza) essas decisōes sāo tomadas. Como ilustraçāo será utilizado o processo de tomada de decisāo de um investidor em titulos no mercado financeiro. SANVICENTE (1999:9) comenta nos primórdios da perspectiva da informação por intermédio dos trabalhos de DEMSKI e FELTHAM (1976). Segundo SANVICENTE (1999:9):

"Segundo esses autores, essa literatura nāo havia desenvolvido, à época em que sua obra foi publicada, uma base conceitual para a escolha entre alternativas de mensuração. Para esses autores, existe um enfoque que preenche essa lacuna: fazer a escolha entre alternativas a partir de uma análise apoiada na teoria económica, e encarada como uma decisāo. Tal como na teoria do consumidor, o que é 'melhor' depende de oportunidades de, preferências e expectativas. Neste caso, o objeto de escolha é informação, e é preciso considerar todos os recursos consumidos em sua obtenção. Assim sendo, a escolha deve ser feita com base no impacto esperado de medidas alternativas de custo sobre os resultados das açōes selecionadas pelos usuários dessas medidas. Os autores reafirmam que nāo se trata de um enfoque revolucionário, mas que apresenta como vantagem reconhecer formalmente o problema de escolha de informação enfrentado pelo contador ou controller" 
Essa apresentação mostra claramente o enfoque dessa nova perspectiva que considera o processo de produção e utilização da informação como similar ao de outro bem econômico qualquer sendo sujeito a formalização advinda da teoria microeconômica. Antes de se continuar na análise, alguns conceitos básicos precisam ser estabelecidos:

- atos: referem-se às várias alternativas disponiveis para os tomadores de decisāo. Em um contexto de análise de investimento, as várias alternativas podem ser consideradas como os vários portfolios possiveis;

- estados: incerteza é descrita em termos de um conjunto de ocorrências possiveis (ou eventos) mutuamente exclusivas e coletivamente exaustivas. Uma descriçāo de cada estado é sưficientemente rica de forma que não há incerteza a respeito das consequeèncias de cada estado, uma vez conhecido;

- consequências: um conjunto de conseqüências para o tomador de decisões é associado a cada estado possivel. Em um cenário de investimentos, as conseqũèncias sāo normalmente descritas em termos de fluxos futuros de caixa (como taxas de juros, dividendos, caixa na venda de títulos, etc.) futuros recebidos;

- preferências: o grau que cada conjunto de conseqūencias é desejável para os agentes. A tomada de decisōes é caracterizada pelo processo de otimização das preferèncias de cada tomador de decisōes. A funçāo de preferència dos agentes é dividida em dois componentes - uma função das crenças é uma função de preferências para o caso de consequeencias certas. A função de preferências, representadas por $U$ (.) é conhecida como funçāo utilidade;

\footnotetext{
${ }^{9}$ Essa linha de pesquisa foi parcialmente desenvolvida pelo Prof. William $\mathrm{H}$. Beaver da Slanford University e pode ser visualizada em BEAVER (1998:18-37)
} 
- crenças: as crenças dos tomadores de decisão referem-se às probabilidades que podem ser subjetivas e individuais atribuídas a cada estado da natureza. Essas probabilidades sāo baseadas na experiência anterior, treinamento e educaçāo dos investidores entre outros fatores. Naturalmente, as crenças são amplamente influenciadas pelo conjunto de informaçōes à disposição dos tomadores de decisāo. Conforme comenta BEAVER (1998: 20):

"Beliefs are the critical element of the decision process, because the role of information is its potential to alter beliefs and hence alter decision-making behaviour."

- função objetivo: a funçāo objetivo é caracterizada como a maximizaçāo da utilidade esperada dos agentes. A utilidade esperada é a 'média' das utilidades dos vários estados da natureza ponderada pelas probabilidades desses. A maximização somente sugere que cada investidor escolhe as opçōes que proporcionam a maior utilidade esperada.

Com base nesses conceitos, pode ser apresentado um exemplo simplificado de decisão de investimento ${ }^{10}$. Assuma que um investidor, neutro em relaçāo ao risco, tem dois titulos como opçōes de investimento (A e B sendo açōes de empresas negociadas em bolsas de valores) e que o preço de cada título é o mesmo $\$ 50$. O valor esperado ao final do periodo é de $\$ 60$ como apresentado na tabela abaixo. 
Tabela 2.1 - Decisão de Investimento

\begin{tabular}{|c|c|c|c|}
\hline Estado & Probabilidade & Preço Final de A & Preço Final de B \\
\hline 1 & 0,5 & $\$ 80$ & $\$ 40$ \\
\hline 2 & 0,5 & $\$ 40$ & $\$ 80$ \\
\hline Preço Final Esperado & & $\$ 60$ & $\$ 60$ \\
\hline
\end{tabular}

Assume-se que o montante a ser investido é fixo $(\$ 10.000)$ e que a única decisão refere-se a quanto investir em cada título. Como o investidor é indiferente ao risco, ignorando-se o pagamento de dividendos e considerações tributárias e operacionais, a única variável relevante é o valor possivel da carteira ao final do periodo. Nesse caso $o$ investidor $\dot{e}$ indiferente entre as alternativas de investimento uma vez que qualquer uma fornecerá a utilidade esperada de $\$$ 12.000 [( $\$ 10.000 / 50) * 60]$. Assim, o investidor nāo demanda informaçōes adicionais e sua decisão não apresenta maiores desafíos. No entanto, assumindose que o lucro da empresa por ação para o período não é conhecido e que esse número pode influenciar a decisão, maiores complicações adicionam-se ao problema

Nesse caso, o papel da informaçāo contábil è o de alterar a probabilidade de ocorrência dos estados futuros na análise do investidor. Assim, será ilustrado o uso do lucro por ação como informação relevante. Simplificadamente, assume-se que existem somente dois "sinais" possiveis relacionados ao lucro da empresa: no sinal $X$ a empresa $A$ apresentará lucro de $\$ 6$ e a $B$ de $\$ 4$; no sinal $Y$ a empresa $A$ apresentará $\$ 4$ e a $B \$ 6$. É importante ressaltar que todos os sinais possiveis devem ser considerados; esse é somente um exemplo simplificado com dois sinais. Com esses dois sinais as probabilidades de ocorrência dos estados 1 e 2 alteram-se para 0.9 e 0.1 com o sinal $X$ e 0.1 e 0.9 com $\circ$ sinal $Y$, 
respectivamente. Essa "nova realidade" levará à revisão da decisão tomada como mostra a tabela 2.2 abaixo.

Tabela 2.2 - Efeito da Informação

\begin{tabular}{|c|c|c|c|c|c|c|}
\hline Sinal & Lucro A & Lucro B & Prob. 1 & Prob. 2 & Preço Final A & Preço Final B \\
\hline $\mathrm{X}$ & $\$ 6$ & $\$ 4$ & 0.9 & 0.1 & $0.9^{*}(\$ 80)+0.1^{*}(\$ 40)=\$ 76$ & $0.9^{*}(\$ 40)+0.1^{*}(\$ 80)=\$ 44$ \\
\hline $\mathrm{Y}$ & $\$ 4$ & $\$ 6$ & 0.1 & 0.9 & $0.1^{*}(\$ 80)+0.9^{*}(\$ 40)=\$ 44$ & $0.1^{*}(\$ 40)+0.9^{*}(\$ 80)=\$ 76$ \\
\hline
\end{tabular}

Onde as probabilidades referem-se aos estados condicionais aos sinais $\mathrm{Xe}$ $Y$. Agora o investidor deve tomar a decisāo que otimize o valor de seu portfolio. Assumindo que os preços sāo os mesmos do exemplo anterior e que o montante para investimento também, se $o$ sinal $X$ for observado a decisão mais adequada será a de investir $100 \%$ dos recursos no título $\mathrm{A}$ que tem uma utilidade esperada de $\$ 15.200$ [(10.000/50)*76]. Da mesma forma, se o sinal $Y$ é o observado o investimento ideal será $100 \%$ dos recursos no título 2 com utilidade esperada de $\$$ 15.200. O investidor não sabe inicialmente qual sinal será apresentado. Assim, ele deve ponderar a utilidade esperada para cada caso em questāo. No exemplo acima o resultado é trivial. No entanto, em exemplos mais realistas a utilidade esperada condicional varia de acordo com os sinais.

Considerando a contabilidade financeira como um sistema de informaçöes para os investidores de mercado de capitais, a sua utilidade para tais investidores pode ser avaliada. Assim, verifica-se que a informaçāo emanada da contabilidade deixa de possuir valor intrinseco e passa a depender do tipo de decisão a ser tomada, da atitude do investidor em relação ao risco (esta foi considerada neutra no exemplo acima) e de outras caracteristicas do processo de decisão. Essa observação é bastante natural dentro da teoria de finanças mas representa um ponto de ruptura com a teoria contábil normativa tradicional. A discussão deixa o foco das caracteristicas ideais da informação por 
intermédio da comparaçăo com conceitos pré-estabelecidos e passa a enfatizar a utilidade esperada dos usuários.

Conforme visto acima, o contexto dentro do qual o usuário da informação tomará as suas decisōes é fundamental para a verificação da utilidade desta. Para o caso do investidor em mercados financeiros, a teoria do portfolio (one period, mean-variance portfolio theory como proxy simplificada para o desenvolvimento do argumento, SHARPE, 1995) fornece a base para a análise. Não será apresentada uma discussão detalhada da teoria do portfolio por fugir dos objetivos do trabalho e por existirem muitas discussões extensas do assunto .SHARPE, (1995) e FOSTER, (1986) são exemplos com abordagens bem simplificadas. Maior fundamentação teórica é fornecida em trabalhos como INGERSOLL, (1996); HUANG and LUTZEMBERGER, (1998) e DUFFIE, (1996).

Dois aspectos da teoria do portfolio são importantes para a contabilidade financeira, segundo BEAVER (1998: 24): (i) os parâmetros relevantes para o investidor estäo resumidos ao retorno esperado do portfolio e seu respectivo risco (variància do retorno), sendo a contribuição dos titulos individuais para estes dois parâmetros do portfolio as variáveis relevantes e nāo o retorno ou risco individual dos titulos"11; (ii) a estratégia adotada pelo investidor (passiva, ativa, agressiva, etc.) influencia a demanda por informaçāo do mesmo. Assim o papel da informaçāo financeira é alterar as crenças dos investidores em relação ao comportamento dos títulos. Neste cenário as crenças do investidor referem-se ao retorno esperado e à variância do retorno do portfolio ${ }^{12}$. Esses dois parâmetros são funçōes do retorno esperado dos títulos individuais, da variância do retorno dos titulos individuais $\left(\sigma^{2}(R i)\right)$ e da covariância ou correlação dos retornos dos

\footnotetext{
"Essa consideração tem pouco relcvância para o retomo do portfolio que scrá a média ponderada dos retomos dos títulos individuais. Para o risco do portfolio a consideraça é mais importante uma vez que o risco do portfolio nảo será a média ponderada das variâncias dos títulos devido a presença de covariância. Assim, parte do risco individual dos títulos poder ser diversificada ficando o portfolio (no caso de diversificação perfeita) somente com o risco sistêmico.

${ }^{12} \mathrm{O}$ retomo de um título refere-se a soma de dividendos e outros recebimentos mais apreciaça (ou menos reduçāo) do valor do mesmo divididos pelo respectivo valor de mercado no inicio do período. $O$ retomo esperado do portfolio é representado formalmente como $E(R p)$ e a variància como $\sigma^{2}(R p)$ respectivamente.
} 
ativos individuais $\left(\sigma^{2}(R i, R j)\right)$. Assim, para ser útil a informaçāo deve impactar esses parâmetros.

O modelo de mercado (market model) fornece uma caracterização do retorno dos títulos. Nesse modelo o retorno de um título é composto de uma parte sistemática e uma nāo sistemática relacionada com o retorno do portfolio de mercado ${ }^{13}$. Mais claramente o modelo de mercado pode ser apresentado da seguinte forma:

$$
R_{1}=\alpha_{1}+\beta_{1} R_{m}+v_{1}
$$

Onde:

$R_{i}=$ retorno do ativo $\mathrm{i}$

$\boldsymbol{R}_{\boldsymbol{m} l}=$ retorno no portfolio de mercado

$v_{i}=$ retorno especifico (nāo sistemático)

$\alpha_{1}=$ intercepto da relaçāo linear

$\beta_{1}=$ parâmetro da relação linear

$\alpha_{i}+\beta_{i} R_{m}=$ parcela sistemática do retorno

Assim, os investidores podem diversificar o risco especifico dos titulos compondo o portfolio possuindo somente demanda por informaçōes acerva do risco sistêmico. Isso demonstra que as demandas dos investidores em relação à informaçōes financeiras de títulos negociados em mercado será dependente da diversificaçāo dos portfolios possuidos. Assim, no caso limite de um investidor que está totalmente diversificado, a única informação relevante refere-se ao beta $\left(\beta_{i}\right)$ do portfolio, sem maiores demandas por informaçōes especificas dos titulos.

Como a diversificaçāo apresenta enormes beneficios para a gestāo do portfolio, por que alguns investidores escolheriam a nāo diversificação e dessa

\footnotetext{
${ }^{13}$ Inclui em tese todos os ativos da economia. Normalmente um indice representativo do mercado de capitais é utilizado.
} 
forma demandariam informaçōes específicas sobre títulos individuais? Segundo BEAVER (1998: 27) duas razões principais podem ser apontadas: (i) custos de transaçāo podem inviabilizar uma estratégia de diversificação especialmente em mercados menos liquidos; (ii) os investidores podem perceber a existência de titulos negociados abaixo do preço necessário para a respectiva remuneraçāo pelo risco. Essas duas motivações pódem aparecer juntamente e estāo relacionadas com o nivel de eficiência do mercado. Para o prosseguimento da análise deve-se definir o conceito de Mercado Eficiente.

- mercado eficiente: segundo MALKIEL (1992:67), pode-se ter a seguinte definição de mercado eficiente:

"A capital market is said to be efficient if it fully and correctly reflects all relevant information in determining security prices. Formally, the market is said to be efficient with respect to some information set ...if security prices would be unnafected by revealing that information to all participants. Moreover, efficiency with respect to na information set implies that it is impossible to make economic profits by trading on the basis of that information set."

Assim, as preferencias dos investidores, e consequentemente a respectiva demanda por informaçōes financeiras, dependem também das caracteristicas gerais do mercado em termos de eficiência ${ }^{14}$. Pode-se depreender de uma análise sucinta da perspectiva da informaçäo para investidores em mercados financeiros que a relativa "ineficiência" de determinado mercado pode aumentar a demanda por informaçōes especificas sobre títulos devido as dificuldades de diversificação. Assim pode-se considerar que a demanda por informações contábeis é maior em

\footnotetext{
${ }^{14}$ Cabe ressaltar que a abordagem da informaçao vendo sendo aplicada em muitos outros cenários de decisāo. Os problemas mais analisados são aqueles relacionados à assimetria de informaçăo, caracteristicas da informaçăo contábil como bem público, seleção adversa, stewardiship, moral hazard e teoria da agência segundo BEAVER (1998: 30-31). Devido ao objetivo deste trabalho o foco deste capitulo continuará relacionado com as decisð̋es de investidores em mercados financeiros
} 
mercados menos eficientes em comparação com os seus correspondentes mais desenvolvidos. KOTHARI (2001:5) comenta a respeito:

"Market efficiency has important implications for the accounting profession. For example, rewards from fundamental analysis would diminush in an efficient market. A switch from one accounting method to another without a direct cash flow effect, a signaling effect, or incentive consequences does not affect securities' prices in an efficient market. Choice between disclosure in footnotes and recognition in financial statements (e.g., accounting for employee stock options) is less contentious from the perspective of its effect on securities' prices in an efficient market. Naturally, the opposite would be true in all of above examples if markets were not efficient. Therefore, there is a demand for empirical research on market efficiency."

Dessa forma, a análise do papel da contabilidade no mercado de capitais brasileiro pode gerar conclusōes importantes acerca da função da informaçāo financeira em mercados menos desenvolvidos.

\subsection{Contabilidade como Mensuração}

A análise da contabilidade dentro da perspectiva da informaçāo ilumina a questāo de como pode-se avaliar a relevância de um conjunto de informaçōes para os investidores atuando em mercados financeiros. Por outro lado, essa abordagem nāo preconiza como os investidores deveriam, a priori, orientar suas preferências. Isto é, não é apresentada uma teoria da avaliação por intermédio da qual investidores possam atribuir valor aos diferentes titulos orientando o processo de decisão. Naturalmente, esse aspecto não é uma deficiência da abordagem da informaçāo uma vez que essa não propōe-se a tal. No entanto, para os objetivos deste estudo é importante que se defina como os investidores podem avaliar os 
ativos no mercado financeiro para que se possa estabelecer uma relação passivel de teste empírico. Neste trabalho, a análise estará centrada em açōes de empresa negociadas em bolsas de valores. Procurar-se-á estabelecer uma relaçăo entre a perspectiva da informação e a teoria de avaliação de investimentos para que se possa orientar o trabalho empírico. A concepção geral é a de estabelecer como os investidores avaliam as suas opçōes de investimento para em seguida deduzir qual o papel da contabilidade nesse processo podendo, assim, estabelecer-se a orientaçāo do trabalho empirico. A preocupação com a mensuração é bastante comum na literatura contábil como observam BEAVER e DEMSKI (1979: 38):

"Financial reporting is heavily concerned with income "measurement". Theorists have, for decades, argued the nature of income and how best to measure it. Practitioners define their task in terms of income measurement. In turn, the FASB's reafirmation of the importance of income raises renewed interest in the measurement issue..."

Para entender a inter-relação entre a contabilidade e a mensuração da realidade econòmica supöe-se inicialmente a existência de títulos avaliados na presença de certeza. Isso significa que todas as expectativas sāo realizadas e que investidores tem informaçōes perfeitas sobre essa realizaçāo. Supondo-se a inexistência de custos de transaçāo, podem ser estabelecidas relaçōes entre os preços dos ativos na economia. Essas relaçōes levam diretamente ${ }^{15}$ a tradicional relaçāo de valor presente. Na hipótese de mercados completos e perfeitos, os investidores podem arbitrar os preços intertemporalmente demandando que estes comportem-se de acordo com a formulação do valor presente. Dessa forma, podese escrever:

$$
{ }^{P} P V_{T}=\sum_{t=1}^{\top}\left[1 /(1+r)^{t}\right] C_{t}
$$

\footnotetext{
is Tem-se nesse caso um problema básico de alocação intertemporal em condiçđes de certeza. Nesses casos o agente escolherá a opqão de consumo vs. investimento com maior valor presente liquido. Isso ocorre porque
} 
Onde:

${ }_{0} P V_{T}=$ é o valor presente (preço, momento 0) do fluxo composto representativo do título pelo periodo $T$

$r=$ taxa de desconto do título

$c_{t}=$ fluxo de caixa a ser recebido no momento $t$.

Essa igualdade garante que não existem oportunidades para lucro de forma que o mercado atinge o equilibrio. Essa formulaçāo, apesar de simplificada, garante que o título com maior valor presente irá sempre ser preferivel àquele com menor valor presente. Essa constatação não depende das caracteristicas individuais dos investidores ou outras consideraçōes. Essa é a base da alocação intertemporal de ativos e da utilização do valor presente como critério fundamental de avaliaçāo de investimentos ${ }^{16}$.

Com base nessas consideraçōes simplificadas, não existe papel para a contabilidade no processo de avaliação de títulos no mercado de capitais. A única possibilidade seria a capacidade preditiva da contabilidade em relaçāo aos dividendos futuros, essa relaçāo ainda demanda testes empiricos. No entanto, muitos autores (OHLSON 1995; FELTHAM e OHLSON, 1995; 1999; PEANMAN, 1996) pregam uma funçāo integrativa à contabilidade. Nessa abordagem, os números contábeis possuem funçāo de avaliaçāo e dessa forma, podem ser usados para mensuraçāo da empresa. Essa è a chamada função de mensuração da contabilidade, em contraponto a função de informaçāo. Pode-se apresentar 0 seguinte exemplo ${ }^{17}$ para uma empresa de um único ativo para integrar as consideraçōes efetuadas com a contabilidade. Inicialmente, as premissas precisam ser estabelecidas:

maiores montantes podem levar o investidor a curvas de indiferença superiores. Detalhamento dessa análisc pode ser vista cm VARIAN (1992)

${ }^{6}$ Maiores detalhamentos da utilizaçio do valor presente como critério de seleçao de investimentos pode ser visto em BREALEY c MYERS (1998). Uma justificaçăo mais detalhada pode ser vista simplificadamente em VARIAN (1999) e com maior teor teórico em VARIAN (1992).

17 Adaptado de BEAVER (1998) e BROMWHICH (1992) 
1. premissas sobre a economia

1.1 certeza
a) todas as expectativas sāo realizadas
b) todos os preços futuros dos ativos são conhecidos

1.2 mercados perfeitos e completos
a) não existem custos de transação
b) não existem oportunidades para lucros anormais
c) não existem oportunidades para arbitragem
d) os preços não sāo afetados por açōes de empresas ou individuos

1.3 taxa de juros é $10 \%$ ao ano.

a) constante ao longo do tempo

b) essa também è a taxa de retorno em todos os ativos

2. premissas sobre a empresa

2.1 a empresa somente possui um ativo

2.2 a empresa é totalmente financiada com recursos próprios

2.3os fluxos de caixa ocorrem discretamente ao final de cada ano

2.4 todo o fluxo de caixa liquido oriundo das operaçōes é pago em dividendos

3. premissas sobre 0 ativo

3.1 a vida útil é de 2 anos

3.20 valor residual è zero

3.3o fluxo de caixa è de $\$ 600$ no primeiro ano e de $\$ 550$ no segundo

3.40 preço de aquisiçăo ao final do ano 0 é de $\$ 1.000$

3.5 a depreciação é econômica e calculada ao final de cada ano 
Tabela 2.3 - Resultados Econômicos

\begin{tabular}{|c|c|c|}
\hline Itens & Ano $1(\$)$ & Ano $2(\$)$ \\
\hline 1. Fluxo de Caixa & 600 & 550 \\
\hline 2. Valor Presente da Firma e do Ativo no Inicio do Ano 1 & $1000^{19}$ & 500 \\
\hline 3. Depreciação Econômica & & \\
\hline 3.1 Valor Presente no Início Periodo & 1.000 & 500 \\
\hline 3.2 Valor Presente no Final do Periodo & 500 & 0 \\
\hline 3.3 Perda de Valor Presente & 500 & 500 \\
\hline 4. Resultado Econômico da Firma e do Ativo & 600 & 550 \\
\hline 4.1 Menos Depreciação Econômica & $(500)$ & $(500)$ \\
\hline 4.2 Resultado Econômico & 100 & 100 \\
\hline 5. Retomo do Investimento & $100 / 1000=10 \%$ & $50 / 500=10 \%$ \\
\hline 6. Resultado Econômico Acionistas & & \\
\hline 6.1 Dividendos Recebidos & 600 & 550 \\
\hline 6.2 Perda de Patrimônio & $(500)$ & $(500)$ \\
\hline 6.3 Resultado Liquido & 100 & 50 \\
\hline 7. Resultado Permanente & & \\
\hline 7.1 Valor Presente Inicio Ano & 1.000 & 500 \\
\hline 7.2 Juros & $10 \%$ & $10 \%$ \\
\hline 7.3 Resultado Permanente & 100 & 50 \\
\hline 8. Valor de Mercado da Firma, Ativos e Patrimônio (Inicio) & 1.000 & 500 \\
\hline 9. Valor de Mercado por Açāolz & 10 & 5 \\
\hline 10. Lucro por Agão & 1 & .50 \\
\hline 11. Relação preço/lucro & 10 vezes & 10 vezes \\
\hline
\end{tabular}

Nesse exemplo, a premissa de mercados completos e perfeitos garante que a taxa de retorno nos investimentos será igual ao custo de capital da empresa, que é a taxa de juros. Assim, a mensuração contábil possui as propriedades necessárias para levar a avaliação da empresa. Da mesma forma que no caso do fluxo de caixa, o valor presente do resultado esperado seria a medida ideal de

${ }^{18} 100$ açðes distribuidas 
escolha entre projetos alternativos. No entanto, resultado econômico não é um conceito contábil e sua implementaçāo prática é bastante difícil. Assim, grande parte da literatura normativa era baseada na discussão de métodos contábeis que se aproximassem mais do resultado econòmico considerado. Critérios de depreciaçāo, por exemplo, foram avaliados de acordo com sua proximidade com a depreciação econômica considerada ${ }^{20}$.

Esse exemplo simplificado ${ }^{21}$ permite visualizar claramente o arcabouço dos teóricos normativos. A proximidade com os conceitos económicos era considerada como critério fundamental para a avaliaçāo de altemativas contábeis concorrentes (como no caso dos métodos de depreciação, por exemplo). Assim, a ênfase do FASB, por exemplo, no lucro como o principal componente das demonstrações contábeis pode ser avaliada. Segundo o FASB, a capacidade de pagamento de dividendos de uma empresa é melhor mensurada pelo lucro contábil do que pelos dividendos pagos atualmente. No exemplo acima, o FASB considera que o lucro de $\$ 100$ é uma medida mais confiável da capacidade de pagamento de dividendos futuros da empresa do que os dividendos atualmente pagos de $\$ 600$. A questão central è que esse nivel de dividendos $(\$ 600)$ nāo pode ser sustentado no longo prazo e, dessa forma, reduz a capacidade de pagamentos futuros. A figura do resultado permanente realmente reflete a capacidade de pagamento de dividendos da empresa, dentro dessa visāo.

Apesar dessas consideraçōes possuirem apelo intuitivo, a construçāo de avaliaçāo da empresa continua sendo baseada integralmente em dividendos, sendo o lucro insignificante. Assim, as consideraçōes iniciais dos órgãos reguladores carecem de uma formulaçāo teórica mais adequada para realmente justificar o papel do resultado contábil como elemento auxiliador do processo de decisāo para investidores em mercado de capitais. Nesse momento, as visōes da

\footnotetext{
${ }^{19} \mathrm{VP}$ ano $\mathrm{l}=(600 / 1.1)+\left(550 / 1.1^{2}\right)=1.000 ; \mathrm{VP}$ ano $2=(550 / 1.1)=500$

20 BEAVER e DUKES (1973) fornecem uma revisào detalhada do assunto.

${ }^{21}$ Exemplos mais detalhados com consideraçðes de mais de um ativo, retenção de resultados e mais de dois periodos é fornecida em BEAVER (1998: 45). No entanto, esses aspectos não contribucm para o entendimento da questão central que aqui se discute.
} 
contabilidade como informaçāo e como mensuração interpōem-se. Segundo a abordagem da informação a contabilidade será importante na medida que alterar as visōes dos investidores a respeito dos parâmetros dos títulos negociados em mercado $\left(E(R p), \sigma^{2}(R p)\right.$ e $\left.\operatorname{cov}(R j, R i)\right)$. Isso significa que a contabilidade e sua mensuração característica nāo possuem valores intrínsecos. A contabilidade somente possui valor na medida que fornece informaçōes úteis sobre o comportamento das instituiçōes sob análise. Esse comportamento é refletido nas variáveis citadas: retorno, risco e correlaçāo. No entanto, o impacto da contabilidade no valor da empresa não é clarificado por essa visāo. A abordagem normativa tradicional não obteve sucesso nessa formulaçāo uma vez que as recomendaçōes acerca de práticas e procedimentos contábeis normalmente eram realizadas isoladamente. Não havia a preocupaçāo com uma integração geral entre os valores contábeis e a expressāo econômica de valor da empresa: o seu preço.

Além dos aspectos representados acima, dentro das hipóteses assumidas, a própria figura da mensuraçāo contábil perde valor. Isto é, se as premissas acima de mercados completos e perfeitos fossem realistas, a própria mensuraçāo contábil seria supérflua. Esse aspecto apresenta a principal crítica dos autores da abordagem da informação em relação à abordagem da mensuração: para que a mensuraçāo contábil se aproxime da econômica, as condiçōes de mercado precisam ser tão restritivas que própria mensuração deixa de ser relevante, conforme observam BEAVER e DEMSKI (1979: 38). Segundo esses autores:

"We conclude this brief summary of income measurement in a conventional neoclassical setting with several additional points. First, the emphasis is on fundamental measurement. We have existence of a mapping from alternative production plans into the real line that (using the $\sim$ relation) represents a complete and transitive ranking of production plans. The measure is by no means unique, but it surely exists and is open to straighforward, conventional interpretation. 
Second, since plans, possibilities, and market prices are all known, no one would would pay an agent to report this measure. Income is already known or is costlessly constructable by each agent. This, of course, follows from the assumptions of certainty and perfect and complete markets."

Segundo esses autores a própria visão da contabilidade como mensuração é inadequada. A análise do exemplo apresentado na tabela 2.3 adicionando incerteza nāo altera a argumentaçāo acima. Conforme visto anteriormente, incerteza é caracterizada por um conjunto de estados que podem ocorrer no futuro. O retorno da compra de um ativo nāo é certo porque o fluxo de caixa fornecido por esse ativo irá depender do estado da natureza que ocorrer. No exemplo do valor das açōes o seu preço dependerá do fluxo futuro de dividendos que é incerto e dependerá da probabilidade dos estados da natureza (assumindo novamente, mercados perfeitos e completos). Estendendo o exemplo anterior temse a seguinte disposição dos fluxos de caixa:

Figura 3 - Fluxo de Caixa na presença de incerteza

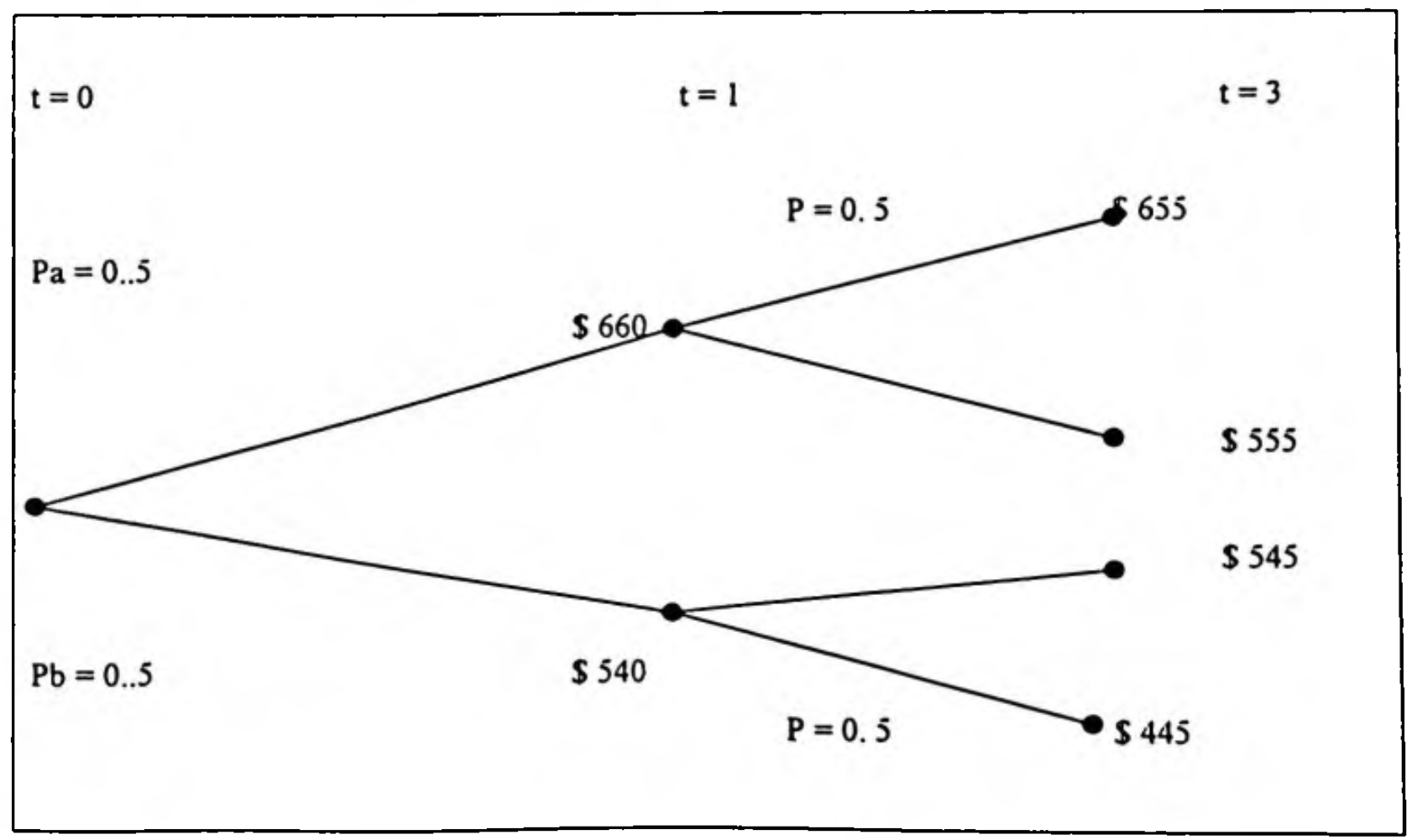


Assim, apresenta-se o problema inicial na presença de incerteza. No primeiro periodo $(t=1)$ um fluxo de caixa de $\$ 660$ (estado A) ou $\$ 540$ (estado B) será recebido. O fluxo de caixa de $t=1$ em $t=0$ é de $\$ 600\left(\$ 660^{*} 0.5+540^{*} 0.5\right)$. Condicionado à ocorrència de $A$, o fluxo de caixa esperado do periodo $t=2 \mathrm{em} \mathrm{t}$ $=1$ é $\$ 605\left(\$ 655^{\star} 0.5+555^{\star} 0.5\right)$. Da mesma forma, o valor esperado de $t=2 \mathrm{em}$ $\mathrm{t}=1$ é $\$ 495$ para o estado $\mathrm{B}$. A tabela seguinte condensa a análise.

Tabela 2.4 - Cálculo em condições de incerteza

\begin{tabular}{|c|c|}
\hline Eventos & Valores (\$) \\
\hline \multicolumn{2}{|l|}{ 1. Ocorrendo o Estado A } \\
\hline 1.1 Fluxo recebido em $t=1$ & 660 \\
\hline \multicolumn{2}{|l|}{1.2 Valor do fluxo remanescente } \\
\hline 1.2.1 Fluxo esperado em $t=2$ & 605 \\
\hline 1.2.2 Valor de mercado dos fluxos remanescentes em $t=1^{22}$ & 550 \\
\hline \multicolumn{2}{|l|}{ 2. Ocorrendo o Estado B } \\
\hline 2.1 Fluxo de caixa em $t=1$ & 540 \\
\hline \multicolumn{2}{|l|}{ 2.2 Valor dos fluxos de caixa remanescentes } \\
\hline 2.2.1 fluxo esperado em $t=2$ & 495 \\
\hline 2.2.2 valor de mercado do fluxo remanescentes em $t=1$ & 450 \\
\hline \multicolumn{2}{|l|}{ 3. Valor de Mercado em $t=0$} \\
\hline \multicolumn{2}{|l|}{ 3.1 Valor em $t=1$ se o estado A ocorrer } \\
\hline 3.1.1 Fluxo de caixa & 660 \\
\hline 3.1.2 Valor de mercado & 550 \\
\hline \multicolumn{2}{|l|}{ 3.2 Valor em $t=1$ se o estado $B$ ocorrer } \\
\hline 3.2.1 Fluxo de caixa & 540 \\
\hline 3.2.2 Valor de mercado & 450 \\
\hline 3.3 Valor esperado em $t=1^{33}$ & 1100 \\
\hline 3.4 Valor de mercado em $t=0$ & 1000 \\
\hline
\end{tabular}


Conforme pode ser observado pelo exemplo, assumindo-se independência na distribuição das taxas de retorno, o valor presente dos ativos da empresa e o valor da mesma podem ser caracterizados como se fossem resultado do desconto dos fluxos futuros de caixa descontados pela taxa de retorno esperada. $O$ valor económico da empresa é igual ao valor presente dos fluxos de caixa remanescentes que é o mesmo valor do ativo. Se o estado $A$ ocorrer, o valor econômico da empresa é de $\$ 1.210$, antes do dividendo referente ao ano 1 , e de $\$ 550$, após o pagamento do dividendo, em $t=1$. Se o estado $B$ ocorrer, o valor econômico da empresa é de $\$ 990$ (antes do dividendo) and $\$ 450$ (após o dividendo). Se o modelo contábil utilizar valores de mercado para mensurar o valor dos ativos, o património da empresa será igual ao valor de mercado da mesma. $O$ valor da divisāo do valor de mercado pelo valor do patrimônio (book-to-market ratio) será igual a 1.

Esses resultados demonstram que dentro da abordagem da mensuraçāo tradicional o papel da contabilidade não é claro. Para que os números contábeis aproximem-se dos económicos é necessário que as condiçōes de mercado sejam tão restritas que a própria mensuraçāo contábil torna-se irrelevante. Dessa forma, a abordagem da mensuraçāo não possui base dentro de uma estrutura econômica rigida.

Do ponto de vista teórico tem-se um ponto critico: a perspectiva da mensuração nāo fomece direçōes normativas e perspectiva da mensuração não possui fundamentaçāo teórica rigida. Nesse sentido o papel da contabilidade fica indefinido. A próxima seção apresenta o modelo de OHLSON que fornece um arcabouço formal para a análise do problema apresentado. O modelo de OHLSON é uma opçāo intermediária entre a abordagem da informaçāo e da mensuração possuindo sólida base teórica o que o fez amplamente utilizado na pesquisa contábil moderna. 


\subsection{Modelo de Ohlson}

Esse modelo apresentado no artigo Earnings, Book Values, and Dividends in Equity Valuation (Contemporary Accounting Research, Vol. 11, $N^{\circ} 2$, p. 661-687 Spring 1995), fornece uma tentativa para a avaliação do valor da firma relacionando este com o patrimônio da mesma, lucros contemporâneos e futuros e dividendos. O artigo conecta a idéia do clean surplus relation (igualdade necessária entre as mudanças no valor do patrimônio e os lucro da empresa no periodo, devidamente ajustado para as distribuiçōes de dividendos, demais reservas e outras particularidades) com a perspectiva da informaçāo para o usuário da contabilidade discutida no capitulo 2. Esta igualdade contábil, aparentemente óbvia, guarda importantes implicaçōes teóricas. Pode-se questionar, por exemplo, se é possivel desenvolver uma teoria para o valor da empresa que seja baseado na clean surplus relation para que seja possivel identificar um papel distinto para o patrimônio, resultado e dividendos? Essa questāo, se adequadamente endereçada dentro de uma estrutura teórica viável, pode esclarecer vários aspectos sobre a avaliaçāo de empresas e a influência da contabilidade neste processo. $\mathrm{O}$ artigo dentro de sua estrutura analítica questiona a possibilidade do desenvolvimento de uma teoria de avaliação patrimonial baseada em papéis especificos destes três componentes da clean surplus relation (CSR de agora em diante).

A importancia do modelo de OHLSON é significativa para a pesquisa em contabilidade. A partir de sua elaboração esse modelo passou a ser a base do trabalho empirico em contabilidade financeira. Conforme LUNDHOLM (1995:749):

"The Oh/son (1995) and Feltham and Oh/son (1995) papers are landmark works in financial accounting. The papers provide a logically consistent framework for thinking about the valuation of accounting numbers. They show how to use book value and income 
together in the same valuation model properly, rather than in a ad hoc fashion: they show how the valuation model can be used to capture different properties of different asset classes, such as operating and financial assets; and they use the model to illustrate the effect of conservative accounting on the relation between equity value, accounting book value, and future earnings."

Da mesma forma, comenta BERNARD (1995:733)

"The Ohlson (1995) and Feltham and Ohlson (1995) studies stand among the most important developments in capital markets research in the last several years. The studies provide a foundation for redefining the appropriate objective of research on the relation between financial statement data and firm value. At the same time they provide some structure for modeling in a field where structure has been sorely lacking.

The value of Oh/son (1995) and Feltham and OhIson (1995) can best be appreciated when one recognizes where the studies fit on the evolutionary tree of research. These studies return to issues so basic as to render them direct descendants of work done no later than the 1960's (eg. Edwards and Bell 1961; Modigliani and Miller, 1958: Miller and Modigliani 1961: and Preinreich 1938). Ohlson (1995) and Feltham and Ohlosn (1995) represent the base of a branch that capital markets research might have followed, but did not. Instead, framed with the so-called informational perspective, research since the late 1960's developed without much emphasis on the precise structure of the relation between accounting data and firm value. In a sense, Ohlson (1995) and Feltham and Oh/son (1995) return to the "step one" and attempt to build a more solid foundation for further work." 
Conforme visto nos comentários acima, a importância do modelo é inquestionável ${ }^{24}$. Inicialmente, apresentam-se as premissas do modelo:

P1. o valor da empresa é igual ao valor presente dos seus dividendos esperados (VPDE de agora em diante). Assim, o cenário é o de percepçōes/crenças objetivas (objective beliefs) de forma que a neutralidade em relação ao risco dos agentes conduz à utilizaçāo de um fator livre de risco (risk free rate; $R f$ de agora em diante) no desconto destes dividendos. Assim:

$$
P t=\sum_{t=1}^{\infty} R^{\tau} E_{t}\left[d_{t+r}\right] \quad \text { (VPDE) }
$$

Onde:

Pt: valor de mercado da empresa (VM) por açăo refletido no preço de suas açōes

Rf: taxa de juros livre de risco (TLR) mais um (uma unidade)

$E_{t}$ [ -1 : operador matemático do valor esperado condicionado na informaçāo possuida na data $t$

$\mathbf{d}_{\mathrm{t}}$ : dividendos liquidos pagos na data $t$

Essa premissa é bastante primitiva e refere-se às condiçōes de não arbitragem intertemporal na economia que resultam em uma variável escalar de preços advinda da transformaçāo do vetor de dividendos futuros quando a taxa de juros è não estocástica, as crenças são homogêneas e os individuos são neutros em relação ao risco.

P2. o CRS é respeitada pelos padröes de contabilidade utilizados ${ }^{25}$. Assim:

\footnotetext{
${ }^{24}$ Está-se referindo ao modelo (singular) apesar de existirem dois artigos. Isso é devido ao fato de apesar da existència do artigo FELTHAM e OHLSON (1995) toda a estrutura do modelo está apresentada do artigo individual de OHLSON que, apesar se somente publicado em 1995, circulou na comunidade acadêmica internacional por mais de dez anos como um working paper.
} 


$$
P L_{t-1}=P L_{t}+d_{t}-L u c_{t}
$$

Onde:

$\mathrm{PL}_{t}$ : $\mathrm{PL}$ liquido na data $\mathrm{t}$

Luc $_{\mathrm{t}}$ : resultado para o período $\mathrm{t}-1, \mathrm{t}$

$d_{t}$ : dividendos liquidos para o periodo

Essa relação simplesmente apresenta a idéia, advinda diretamente da igualdade patrimonial, de que o patrimônio deste ano (por exemplo) iguala o patrimônio do ano passado mais o resultado contábil menos os dividendos liquidos $^{26}$ distribuidos. Cabe ressaltar que essa é uma premissa utilizada para simplificar o trabalho. Não é feita nenhuma recomendação a esse respeito.

P.3 o goodwill é expresso pelo valor presente dos resultados anormais (abnormal earnings) esperados. Este "resultado anormal" è calculado pela subtraçāo do resultado do periodo menos o custo de utilização do capital, sendo este último mensurado pelo patrimônio do inicio multiplicado pela taxa de juros livre de risco. Este valor também é conhecido como residual earnings ou resultado residual. Esta consideraçāo é dependente do comportamento dos números contábeis como visto adiante em P7;

P.4 o pagamento de dividendos afeta o patrimônio do periodo mas nāo afeta o valor do resultado. Os dividendos pagos hoje influenciam negativamente os resultados futuros esperados. Os dividendos podem ser "substituidos" pelo valor de mercado em uma relação de um para um de forma que a estratégia

\footnotetext{
3s Pode-se verificar que em muitos casos os padrocs de contabilidade normalmente accitos niao respeitam a CSR como é o caso do SFAS 52, Foreign Currency Translation. Em casos como o dessc pronunciamento, os ganhos e perdas advindos de flutuaçðes na moeda estrangeira nåo transitam pelo resultado, sendo contabilizados diretamente no patrimònio em contas especificas. No caso brasileiro tem-se a reserva de correçăo monetária como exemplo desse tipo de violaçăo da CSR.

${ }^{26}$ A observaçao a respeito dos dividendos liquidos distribuidos é somente para mostrar que o modelo admite dividendos negativos (as contribuiçð̋es dos acionistas såo superiores aos dividendos pagos).
} 
adotada para o pagamento dos dividendos é irrelevante. Neste contexto o comportamento estocástico das informações contábeis leva a um modelo contábil de múltiplos periodos de forma que o resultado e o valor do patrimônio ajam como fatores complementares na avaliação;

P.5 as propriedades de MODIGLIANI e MILLER (1958) são plenamente satisfeitas, isto é, a política de dividendos é absolutamente irrelevante mesmo na presença de impostos;

P.6 o modelo admite que existem informações além daquelas representadas pelo patrimônio, resultado e dividendos. Assim, alguns eventos relevantes afetam o valor esperado dos resultados futuros mas não o valor atual dos mesmos. Considera-se então que a contabilidade possui um diferencial temporal no reconhecimento dos eventos que impactam o valor da empresa;

$\boldsymbol{P} .7$ o comportamento estocástico da série de tempo composta pelos lucros anormais é aproximado por uma funçāo linear. Essa premissa é necessária uma vez que o valor dos lucros anormais é calculado por intermédio da aplicação da taxa livre de risco ao valor inicial do patrimônio que é subtraido do resultado do periodo. Assim, estes lucros sāo resultado do lucro do periodo menos o custo livre de risco do capital investido. Com base nestas afirmações a previsão do valor da empresa se desloca da previsão do comportamento dos dividendos futuros esperados para o comportamento dos resultados anormais (LuG ${ }^{a}$ de agora em diante). Assim, os valores de Luc ${ }^{a}{ }_{1+1}$ săo linearmente relacionados com Luc $^{a}$. mais uma correçāo de escala para uma variável $\mu_{t}$ que representa toda as outras informaçōes relevantes que não a contäbil. Essa variável $\mu_{t}$ satisfaz um processo autoregressivo regular. Assim:

$$
\begin{aligned}
& \operatorname{Luc}_{t}^{*} \equiv \mathrm{LuC}_{\mathrm{T}}-\left(R_{F}-1\right) \mathrm{PL}_{T-1} \\
& \text { LuC }_{t+1}^{\alpha}=\Delta L u C^{*}{ }_{t}+v_{t}+\varepsilon_{1 t+1}
\end{aligned}
$$




$$
v_{t+1}=r v_{t}+\varepsilon_{2 t+1}
$$

Onde $\omega$ e $\gamma$ sāo parâmetros conhecidos com valores entre 0 e 1 e os valores de $\varepsilon^{\prime}$ ' possuem média zero e não sāo correlacionados com as outras variáveis do modelo. Basicamente a construção (A3) estabelece que os resultados anormais e as outras informaçōes nāo contábeis são autoregressivos. Em adição pode-se considerar as informaçōes não contábeis como choques sobre os resultados anormais do periodo seguinte. As informações nāo contábeis podem ser completamente imprevisiveis $(\gamma=0$ ), ou parcialmente previsiveis ( $\gamma$ $=1$ ). No entanto, essas informaçōes não contábeis impactam os resultados anormais no periodo seguinte (em um cenário simplificado de somente dois periodos). A diferença entre $+v_{t}$ e $\varepsilon_{t t+1}$ é que $\circ$ primeiro pode ser parcialmente previsivel enquanto que o segundo é totalmente imprevisivel. É importante notar que o choque advindo de informaçōes que nāo sāo contábeis no periodo $t$ torna-se parte do processo autorregressivo de $\operatorname{LuC}^{\mathrm{a}}{ }_{\mathrm{t}+1}$ desse momento em diante. Assim, a informação nāo contábil gera choques de forma autorregressiva e esses choques sāo incorporados nos resultados anormais futuros da mesma forma. Pode-se argumentar que nem toda a informaçāo não contábil de um dado periodo t torna-se-á parte dos resultados anormais do periodo $t+1$. No entanto, relaxando-se um pouco as restrições do modelo, essas informaçōes serāo incorporadas pelo resultado contábil em algum momento no futuro. Uma propriedade da relação (A3) é que o pagamento de dividendos reduz o resultado contábil no periodo seguinte no montante da taxa de juros livre de risco $\left(R_{F}\right)$ que a empresa poderia ter obtido em seus ativos. Essa premissa é conhecida como dinâmica informacional linear.

P.8 a taxa de juros possui uma estrutura nāo estocástica e fixa ao longo do tempo. 
Essas premissas levam a um modelo fechado, linear, para explicação do goodwill. Assim, o valor da empresa é igual ao seu patrimônio mais uma função linear dos resultados anormais (RA) atuais e uma variável escalar $\mu_{t}$ representando o conjunto de outras informações. Além desta constatação duas outras conseqüências importantes das definiçōes acima sāo as seguintes:

(i) um aumento no pagamento de dividendos em uma dada data reduz o resultado esperado para o próximo periodo. Como está-se considerando a neutralidade em relação ao risco, o efeito marginal do pagamento de uma unidade monetária no resultado do periodo seguinte é igual à taxa livre de risco (Rf) sendo usada.

(ii) da mesma forma, um aumento nos dividendos reduz o valor agregado do resultado para os dois periodos sendo que a taxa de juros acumulada para os dois periodos determina o efeito.

Essas duas conseqüèncias da distribuiçăo da riqueza para os proprietários explicam melhor o requisito básico de que os dividendos reduzem 0 patrimônio mas deixam o resultado do periodo inalterado. Os dividendos tem efeitos nos resultados contábeis futuros. Essa consequència está relacionada com a idéia de que o resultado do periodo seguinte depende do patrimônio do periodo atual. Essa relaçāo torna-se explícita quando transforma-se a dinâmica dos resultados anormais para expressar o resultado do periodo seguinte em uma funçāo do patrimônio atual, da mesma forma que o resultado do periodo e dividendos. Uma outra consideraçāo, derivada diretamente das premissas adotadas pode ser apresentada a seguir:

C1. o patrimônio (PL de agora em diante) é um estimador não viesado do valor de mercado (VM de agora em diante). Isso ocorre porque o goodwill esperado (incondicional) (GE de agora em diante) iguala a zero. Em outras palavras, apesar 
de que os valores do goodwill possuírem correlação positiva, em um horizonte de longo prazo a média tende a igualar a zero. Assim:

$$
\text { GE }=\text { MVt }-P L t
$$

sendo que:

$$
P L t=M V t+\epsilon t
$$

onde $\epsilon_{\mathrm{t}} \sim N\left(\mu_{\mathrm{i}} \sigma_{\mathrm{i}}^{2}\right)$ e $\mu_{\mathrm{i}}=0$, uma vez que GE não é observável em t. Isso decorre de o patrimônio ser um estimador não viesado do preço de mercado.

Pode-se observar o mesmo fenômeno de não viés na série de tempo quando se avalia a diferença entre $\circ$ resultado capitalizado e $\circ$ valor da organização. Os resultados esperados para o próximo periodo, ponderados pelo inverso da taxa livre de risco, determina o valor da organizaçāo segundo o argumento acima. Neste caso, o valor do resultado esperado para o próximo periodo fornece informaçāo suficiente para 0 valor presente de todos os dividendos futuros esperados. RAMAKRISHNAN (1990) demonstra que se a politica de dividendos for tal que a totalidade do resultado for distribuida na forma de dividendos, então os resultados esperados no futuro distante se igualarão ao valor do patrimônio multiplicado pela taxa livre de risco.

Com base nessas constataçōes iniciais pode-se apresentar o desenvolvimento do modelo. Pode-se aplicar a CSR para expressar o preço da empresa (Pt) em termos dos resultados futuros (esperados) e patrimônio líquido apesar da seqüência de dividendos esperados na fórmula do VPDE. Assim:

$$
\operatorname{LuC}_{i}^{2} \equiv \operatorname{LuC}_{t}-\left(R_{F}-1\right) P L_{t-1}
$$

combinado com (A2):

$$
d_{t}=L U G_{t}^{*}-P L_{t}+R_{f} P L_{t-1}
$$


Usando essa equação para substituir $d_{t+1}, d_{t+2}, \ldots$ na fórmula do VPDE:

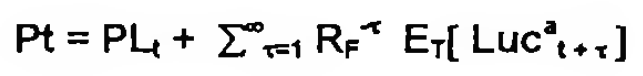

Assumindo que $E_{T}\left[P L_{t+\tau}\right] / R_{F}{ }^{\tau} \rightarrow 0$ quando $\tau \rightarrow \infty$.

Cabe lembrar que, por exemplo, para um fundo de investimentos que remunera à taxa $\mathrm{Rf}$ tem-se $x_{t}^{a}=0$ e dessa forma $P t=P L_{t}$. Não se está considerando que os resultados ou mesmo os dividendos são constantes, pois eles dependem de eventos aleatórios.

A equação 1 acima possui várias implicaçōes. Inicialmente, pode-se ver que os resultados esperados podem substituir o valor dos dividendos na fórmula do VPDE. Essa relação foi apresentada à literatura contábil inicialmente por EDWARDS e BELL (1961) e recentemente por PEASNELL (1981, 1982), sem possuir, no entanto, o mesmo grau de formalizaçāo apresentado aqui. Em seguida pode-se ver que o valor da firma iguala o património acrescido dos resultados anormais esperados descontados ao presente; assim este valor dos resultados anormais é justamente o número que reconcilia o valor do patrimônio da empresa com o seu valor de mercado. Essa conclusão é plenamente aceitável dada a premissa P3 levantada anteriormente. É interessante ver que a equaçāo (1), conforme notado por PEASNELL (1982), não depende do modelo contábil adotado.

Assim, verifica-se que o modelo apresentado permite, dentro das premissas estabelecidas, avaliar o valor de mercado da empresa por intermédio de variáveis contábeis sem que haja dependência direta do modelo contábil adotado. Este resultado é fundamental para a teoria da contabilidade moderna na medida que ele realiza uma ligaçăo importante entre a informação emanada pela contabilidade e a moderna teoria de finanças. Essa relaçăo traz para a contabilidade uma importância grande na avaliaçāo de organizaçōes. Esse novo papel da 
contabilidade não está baseado em considerações normativas mas em uma dedução analitica lógica dentro do mainstream da teoria de finanças.

Apesar da simplicidade e elegância do modelo de OHLSON algumas questões são normalmente mal interpretadas dentro da estrutura proposta. Conforme comenta LUNDHOLM (1995:749):

"I have seen each of these papers presented in workshops, at conferences, and in Ph.D. seminars. In all of these forums, certain questions arise repeatedly...Probably the most frequently asked questions in Ph.D. classes (and in private conversations among faculty) is "how does the model really work?" While everyone can follow the simple algebra that is used to go from one equation to the next, few people feel that they fully understand the model. There are also three questions asked repeatedly by empirical researchers: (1) what about nonaccounting information, (2) how can you claim dividend irrelevancy when we know that dividend increases are goodnews signals and (3) how restricitive is the linear information dynamic?. Finally, theorists frequently ask whether unbiased accounting is better or worse than conservative accounting, and a more philosophical question, what are the criteria by which we should judge the model?

Para tentar esclarecer tais aspectos e introduzir as questōes analisadas nesta tese, serāo apresentados os seguintes exemplos adaptados de LUNDHOLM (1995:749-761).

\section{Exemplo 1}

Assumindo-se uma empresa que começa suas operaçōes em $t=0$ com um capital inicial de $\$ 100$ com o qual comprou ativos produtivos que não produzirão 
nenhum tipo de resultado em $t=1$ (assumindo-se um periodo de preparação ou setup) e produzirão um resultado incerto $z$ em $t=2$. A empresa liquidará alguns de seus ativos em $t=1$ para pagar um dividendo $d_{1}$ e também pagará um dividendo final $d_{2} e m t=2$. Esse cenário é apresentado na tabela 2.5 abaixo.

TABELA 2.5 VALORES REALIZADOS PARA O EXEMPLO 1

\begin{tabular}{|c|c|c|c|}
\hline Periodos & Patrimônio na data $\mathbf{t}$ & Lucro na data $\mathbf{t}$ & Dividendo na data $\mathbf{t}$ \\
\hline $\mathbf{0}$ & 100 & 0 & -100 \\
\hline $\mathbf{1}$ & $100-\mathrm{d}_{1}$ & 0 & $\mathrm{~d}_{\mathbf{1}}$ \\
\hline $\mathbf{2}$ & 0 & $Z$ & $100-\mathrm{d}_{\mathbf{1}}+\mathrm{z}$ \\
\hline
\end{tabular}

Usando a equaçāo (1) apresentada acima tem-se:

$$
\begin{gathered}
P o=100+R_{F}^{-1} E\left[0-\left(R_{F}-1\right) 100\right]+R_{F}^{-2} E\left[z-\left(R_{F}-1\right)\left(100-d_{1}\right)\right] \\
P o=R_{F}^{-1} E\left(d_{1}\right)+R_{F}^{-2}\left[E(z)-E\left(d_{1}\right)+100\right]
\end{gathered}
$$

E para o ano seguinte:

$$
\begin{gathered}
P_{1}=100-d_{1}+R_{F}^{-1}\left[E(z)-\left(R_{F}-1\right)\left(100-d_{1}\right)\right] \\
P_{1}=R_{F}^{-1}\left[100-d_{1}+E(z)\right]
\end{gathered}
$$

Pode-se observar que o disconto dos valores $d_{T}$ apresentados na tabela 2.5 fornecem exatamente esses resultados. No entanto, nas premissas do modelo, foi especificado que este respeita as propriedades de MODIGLIANI e MILLER, isto é, os preços correntes nāo dependem do momento em que os dividendos futuros sāo pagos. Assim, porque $P_{1}$ depende dos valores de $E\left(d_{1}\right)$ ? Essa especificação contraria o que foi especificado inicialmente. 
Uma propriedade da Premissa 7 (P7) é que o pagamento de dividendos reduzem o lucro contábil do próximo periodo pelo montante que poderia ter sido gerado pela aplicação da taxa livre de risco sobre os ativos. Pode-se observar esse aspecto claramente pela substituição da definição de resultados anormais no processo representado pela primeira equação de (A3). Assim:

$$
\operatorname{LuC}_{T+1}=\left(\dot{R}_{\mathrm{F}}-1\right) P L_{T}+\operatorname{\omega LuC}_{T}^{\mathrm{a}}+v_{T}+\varepsilon_{1 t+1}
$$

Como o pagamento de dividendos reduz o valor do patrimônio corrente mas nāo afeta os resultados correntes, tem-se:

$$
\partial \mathrm{E}\left(\mathrm{Luc}_{\mathrm{T}+1}\right) / \partial \mathrm{d}_{\mathrm{T}}=-\left(\mathrm{R}_{\mathrm{F}}-1\right)
$$

Vè-se que uma unidade de dividendos paga no periodo atual reduz o lucro esperado do próximo periodo pelo montante da aplicação da taxa de juros sobre essa unidade. Essa propriedade foi violada no exemplo 1, onde o lucro $z$ em $t=2$ era independente de do dividendo pago em $t=1$. Na ausència de qualquer fonte de informaçōes anormais $\left(\omega=0\right.$ e $\left.v_{T}=0\right)$ a premissa $(P 7)$ estabelece que os lucros esperados serāo simplesmente a multiplicaçāo da taxa de juros livre de risco pelo valor do patrimônio líquido. O próximo exemplo será consistente com a premissa (P7) simplesmente pela consideração da taxa de juros sobre o patrimônio.

\section{Exemplo 2}

A empresa começa em $t=0$ com uma integralizaçăo de capital de $\$ 100$ e imediatamente compra ativos produtivos que pagam a taxa de juros livre de risco $\left(R_{F}-1\right)$ sobre os valores de livro e um montante incerto $z$ em $t=2$. A empresa liquidará parte de seus ativos em $t=1$ para pagar um dividendo $d_{1}$ e irá pagar um dividendo final $d_{2}$. Esses montantes estão sumarizados na tabela abaixo. 
TABELA 2.6 VALORES REALIZADOS PARA O EXEMPLO 2

\begin{tabular}{|c|c|c|c|}
\hline Periodos & Patrimônio na data $t$ & Lucro na data $t$ & Dividendo na data $t$ \\
\hline 0 & 100 & 0 & -100 \\
\hline 1 & $R_{F} 100-d_{1}$ & $\left(R_{F}-1\right) 100$ & $d_{1}$ \\
\hline 2 & 0 & $\left(R_{F}-1\right)\left(R_{F} 100-d 1\right)+z$ & $R_{F}\left(R_{F} 100-d_{1}\right)+z$ \\
\hline
\end{tabular}

Nesse exemplo os resultados anormais săo 0 em $t=1$ e $Z$ em $t=2$. Nāo existem informaçōes fora do modelo contábil neste exemplo e os resultados anormais nāo dependem dos resultados anormais anteriores, isto é $\omega=0$ e o valor $Z$ deve ser interpretado como o termo de erro $\varepsilon_{1++1}$. Aplicando a fórmula de avaliaçāo de OHLSON (1) tem-se:

$$
\begin{gathered}
P o=100+R_{F}^{-2} E(z) e \\
P_{1}=R_{F} 100-d_{1}+R_{F}^{-1} E(z)
\end{gathered}
$$

Novamente pode-se ver que os preços são iguais aos obtidos pelo desconto do fluxo futuro de dividendos. A única mudança em relaçāo ao exemplo anterior é a consideração da taxa $\left(R_{F}-1\right)$ sobre o patrimônio. Neste exemplo, no entanto, a política de dividendos é irrelevante uma vez que um aumento de uma unidade monetária nos dividendos correntes simplesmente reduz o preço corrente em exatamente uma unidade monetária $\left(\partial \mathrm{P}_{\mathrm{T}} / \partial \mathrm{d}_{\mathrm{T}}=-1\right)$.

O exemplo 2 também pode ser adaptado para considerar informações que não a contábil. Assuma que $z$ é informação não contábil conhecida de todos os agentes em $t=1$. Para que essa informação seja incorporada basta que seja criada uma coluna $v_{T}$ na tabela 2.6 com $v_{0}=0, v_{1}=z$ e $v_{2}=0$ e, como $z$ é imprevisivel, $\gamma=0$ (A3). Nesse caso $P_{1}$ permanece o mesmo e $E(z)$ é substituido por $z$ em $P_{1} .0$ contraste entre os exemplos 1 e 2 ressalta a importância da dinàmica 
informacional linear (A3). O teste dessa premissa é, em última análise, empírico, conforme comenta LUNDHOLM (1995:754)

"The descriptive validity of ${ }^{27}$...is ultimately an empirical question, but its theoretical elegance cannot be denied. By assuming an autoregressive process for abnormal earnings, the assumption ties normal earnings and dividends together in such a way as to render the dividend policy irrelevant"

Conforme mencionado anteriormente, o modelo de OHLSON trabalha com a idéia de que o pagamento de dividendos reduz o valor da empresa. Essa premissa tem sido fortemente questionada por empiricistas que argumentam que os preços das ações aumentam quando do anúncio de aumento no pagamento de dividendos (ASQUIT e MULINS, 1983). O fundamento desse evento é que o aumento no pagamento de dividendos é um "sinal caro" utilizado por gestores que possuem realmente boas noticias para comunicar ao mercado. Será que essa observação pode ser conciliada com o trabalho de OHLSON? O próprio exemplo 2 serve para demonstrar que o modelo continua válido mesmo se os dividendos fornecerem sinais relevantes para o mercado.

Assuma que a série de valores para o patrimònio, dividendos e lucros sāo exatamente as mesmas apresentadas no exemplo 2, com a única exceçäo que o administrador escolhe $d_{1}$ em $t=1$ sabendo $\circ$ valor de $z$, enquanto que os investidores externos nāo possuem tal informação. Nesse caso, os gestores podem escolher $d_{1}$ para sinalizar informaçōes para o mercado sobre o real valor de $z$. Para que o equilibrio possa ser obtido, deve existir alguma forma de friç̧āo que faça com que o pagamento de um dividendo maior consuma menos recursos para um administrador com alto $z$ do que para outro com $z$ menor. Esse situaçāo favorável pode ser, por exemplo, que para um administrador com z maior a probabilidade de falência seja menor. Dessa forma, independentemente dos

${ }^{27}$ Referindo-se a premissa $\mathrm{A} 3$. 
custos de sinalização, o valor de $d_{1}$ é, pelos menos em parte, informativo a respeito do valor de $z$. Assim, investidores formam a expectativa $E\left(z \mid d_{1}\right)$ em $t=1$. Com essa especificação, o preço em $t=1$ será:

$$
P_{1}=R_{F} 100-d_{1}+R_{F}^{-1} E\left(z \mid d_{1}\right)
$$

E consequentemente:

$$
\partial P_{1} / \partial d_{1}=-1+R_{F}^{-1} \partial E\left(z \mid d_{1}\right) / \partial d_{1}
$$

A exata relaçāo entre $E\left(z \mid d_{1}\right)$ e $d_{1}$ será determinada em equilibrio, pois 0 gestor considerará essa expectativa ao escolher $d_{1}$. Como pode ser visto, a equação (2) considera o efeito imediato $(-1)$ do pagamento de dividendos e o efeito de sinalizaçāo $\left(R_{F}{ }^{-1} \partial E\left(z \mid d_{1}\right) / \partial d_{1}\right)$. Considera-se $\partial E\left(z \mid d_{1}\right) / \partial d_{1}$ como positivo. Em algumas regiōes do equilibrio considerado, um pequeno aumento no dividendo pode ocasionar grandes aumentos em $z$. Nesse caso, $\left(R_{F}^{-1} \partial E\left(z \mid d_{1}\right) / \partial\right.$ $d_{1}$ ) dominará o termo $(-1)$ e o preço aumentará para pequenos aumentos nos dividendos. No entanto, o efeito negativo do aumento dos dividendos $(-1)$ continua presente e deve dominar o efeito de sinalizaçāo $\left(R_{F}{ }^{-1} \partial E\left(z \mid d_{1}\right) / \partial d_{1}\right)$ para dividendos suficientemente grandes. Dessa forma, dentro da dinàmica do modelo de OHLSON, esses dois fatores interagem. No entanto, o efeito de sinalizaçāo é secundário em comparação com o efeito direto do pagamento de dividendos como comenta LUNDHOLM (1995: 755)

"If the firm pays out most its assets in dividends then the value of a claim on the remaining few assets must be lower. In this sense, the negative effect is primary and the dividend signalling effect is only secundary." 
Dessa forma, a dinãmica informacional apresentada pelo modelo de OHLSON não é prejudicada pelo efeito de sinalização devido ao efeito secundário deste quando comparado com o efeito direto do pagamento de dividendos.

A discussão a respeito das qualidades de um modelo contábil não viesado em comparação com a estrutura conservadora utilizada tradicionalmente ocupa papel central na literatura de contabilidade financeira. Essa questão é investigada neste trabalho (terceira hipótese testada; item 4.3 Reconhecimento assimétrico e conservadorismo e os resultados são apresentados no item 5.4 Reconhecimento e conservadorismo) com o objetivo de avaliar as caracteristicas do lucro contábil publicado pelas empresas brasileiras. Dentro do modelo de OHLSON, a contabilidade é considera nāo viesada se a diferença esperada na data t entre o preço futuro e o patrimônio contábil futuro eventualmente é igual a zero: $E_{T}\left(P_{\varepsilon}\right.$ $\left.P L_{\tau}\right) \rightarrow 0$ quando $\tau \rightarrow 0$. A contabilidade é definida como conservadora se $E_{T}\left(P_{\tau}\right.$ $\left.P L_{\tau}\right) \rightarrow K>0$ quando $\tau \rightarrow 0$. Essa definiçāo requer muito pouco do modelo contábil para que esse seja considerado não viesado uma vez que o horizonte temporal não está definido. Pode-se, no entanto, definir uma versāo modificada, mais restrita, da especificaçāo acima: $E_{0}\left(P_{1}-P_{1}\right)=0$. Essa definição mantém a concepçāo geral de OHLSON, mas é focada em um horizonte definido. Essa especificação será usada no exemplo a seguir para ilustrar a questão do conservadorismo dentro do modelo de OHLSON.

\section{Exemplo 3}

Considerando-se 0 mesmo investimento inicial de $\$ 100$ unidades monetárias do evento anterior, o principio da competència requer que os juros $\left(R_{F}\right.$ -1 ) sejam reconhecido em cada periodo. No entanto, o resultado incerto $z$ pode ser reconhecido de diversas formas. $O$ valor de $z$ é conhecido em $t=1$ de forma que $v_{T}$ assume os valores de $v_{0}=0, v_{1}=z$ e $v_{2}=0$. Supondo que a norma contábil imponha que $z$ não seja reconhecido até a sua realização em $t=2$. Nesse caso: 


$$
\begin{gathered}
P_{1}=R_{F} 100-d_{1}+R_{F}^{-1} z \quad e \\
E_{0}\left(P_{1}-P L_{1}\right)=R_{F}^{-1} E(z)
\end{gathered}
$$

Assim, as regras contábeis que reconhecem totalmente $o$ valor de $z$ em $t=2$ será nāo viesada somente se $E(z)=0$; sendo conservadora se $E(z)>0$ e agressiva se $E(z)<0$. Esse resultado somente estabelece que a falha em reconhecer "boas noticias" torna a contabilidade conservadora. Nesse cenário o patrimônio contábil estará "atrasado" em termos do reconhecimento do resultado econômico.

Supondo agora que o valor presente de $z$ é reconhecido no resultado contábil em $t=1$. Tem-se a seqüència de valores apresentado na tabela abaixo.

\section{TABELA 2.7 VALORES REALIZADOS PARA O EXEMPLO 3}

\begin{tabular}{|c|c|c|c|}
\hline Periodos & Patrimônio na data $t$ & Lucro na data $t$ & Dividendo na data $t$ \\
\hline 0 & 100 & 0 & -100 \\
\hline 1 & $R_{F} 100-d_{1}+R_{F}^{-1} z$ & $\left(R_{F}-1\right) 100+R_{F}^{-1} z$ & $d_{1}$ \\
\hline 2 & 0 & $\left(R_{F}-1\right)\left(R_{F} 100-d 1+R_{F}^{-1} z\right)$ & $R_{F}\left(R_{F} 100-d_{1}\right)+z$ \\
\hline
\end{tabular}

A única mudança entre a tabela 2.6 e 2.7 é que os valores do lucro contábil e do patrimônio sāo acrescidos pelo valor presente de $z$ em $t=1\left(R_{F}^{-1} z\right)$ e o lucro não inclui o valor $z$ em $t=2$. Como $v_{1}=z$ é conhecido dentro de ambas as regras de reconhecimento, $P_{1}$ é dado pela equaçāo $\left(3: P_{1}=R_{F} 100-d_{1}+R_{F}{ }^{-1} z\right.$ ). No entanto, como $\mathrm{PL}_{1}$ mudou tem-se agora:

$$
E_{0}\left(P_{1}-P L_{1}\right)=0
$$

para todos os valores de $E(z)$ 
Se o montante nominal de $z$ fosse reconhecido em $t=1$, ao invés do seu valor presente, seria observado um modelo contábil conservador novamente porque o preço é baseado no valor presente de $z$. Não é surpreendente que um sistema contábil que reflete o valor presente dos fluxos de caixa esperados imediatamente quando esses são conhecidos seja não viesado. Deve-se observar que, para que o sistema contábil não seja viesado é necessário que os fluxos de caixa sejam reconhecidos quando conhecidos e que este reconhecimento seja feito pelo valor presente de tais fluxos. A ausência desse reconhecimento é que produz o viés na mensuração contábil em termos da mensuração econômica. Esse viés pode ser conservador ou agressivo.

Uma forma alternativa de ilustrar a natureza do conservadorismo na contabilidade é examinar a relação entre o patrimônio e o lucro. Para o exemplo 3 acima, o preço em $t=1$ é o mesmo independentemente do momento do reconhecimento de $z$. No entanto, o patrimônio e os resultados anormais diferem dependendo do método de reconhecimento utilizado. A tabela seguinte ilustra a questāo:

\section{TABELA 2.8 DIFERENÇAS NO PATRIMÔNIO E NOS RESULTADOS}

ANORMAIS

\begin{tabular}{|c|c|c|c|}
\hline Preço & Patrimônio & Resultado Anormal & Reconhecimento \\
\hline$P_{1}$ & $R_{F} 100-d_{1}+R_{F}^{-1} z$ & 0 & $z$ reconhecido em $t=1$ \\
\hline$P_{i}$ & $R_{F} 100-d_{i}$ & $R_{F}^{-1} z$ & $z$ reconhecido em $t=2$ \\
\hline
\end{tabular}

0 modelo contábil conservador reconhece $z$ em $t=2$ causando um decréscimo no patrimônio corrente e que é contrabalançado por um aumento no valor dos resultados anormais futuros. Dessa forma, o modelo conservador de reconhecimento reduz o valor do patrimônio (em comparaçăo com o econòmico) e aumenta, consequentemente, o valor dos resultados anormais futuros. 
O exemplo seguinte ilustra um tipo de conservadorismo que não é capturado pelo modelo de OHLSON: reconhecendo 'más' notícias antecipadamente e 'boas' noticias com atraso.

\section{Exemplo 4}

Supondo que, dentro da estrutura de investimento apresentada nos exemplos anteriores, $o$ valor presente de $z$ seja reconhecido em $t=1$ se $z<0$ e esse seja reconhecido em $t=2$ se $z>0^{28}$. A consideração dessa situação dá origem aos resultados apresentados na tabela abaixo, onde as três primeiras linhas representam 0 caso de $z<0$ e as duas últimas representam o caso onde $>>0$ (representados como 1' e 2').

TABELA 2.9 VALORES REALIZADOS PARA O EXEMPLO 4

\begin{tabular}{|c|c|c|c|}
\hline Periodos & Patrimônio na data $t$ & Lucro na data $t$ & Dividendo na data $t$ \\
\hline 0 & 100 & 0 & -100 \\
\hline 1 & $R_{F} 100-d_{1}+R_{F}^{-1} z$ & $\left(R_{F}-1\right) 100+R_{F}^{-1} z$ & $D_{1}$ \\
\hline 2 & 0 & $\left(R_{F}-1\right)\left(R_{F} 100-d 1+R_{F}^{-1} z\right)$ & $R_{F}\left(R_{F} 100-d_{1}\right)+z$ \\
\hline $1^{\prime}$ & $R_{F} 100-d_{1}$ & $\left(R_{F}-1\right) 100$ & $d_{1}$ \\
\hline $2^{\prime}$ & 0 & $\left(R_{F}-1\right)\left(R_{F} 100-d 1\right)+z$ & $R_{F}\left(R_{F} 100-d_{1}\right)+z$ \\
\hline
\end{tabular}

Se $z<0$, a sequència de valores na tabela 2.9 será a mesma da tabela 2.7 , de forma que $E_{0}\left(P_{1}-P L_{1}\right)=0$. Por outro lado se $z>0$, a sequência é a mesma da tabela 2.6 chegando-se ao mesmo valor de P1 obtido em (3). No entanto, levandose em conta os valores de $P L_{1}$ apresentados na tabela acima para $t=1$ ' tem-se:

$$
E_{0}\left(P_{1}-P L_{1}\right)=\operatorname{Prob}(z<0) 0+\operatorname{Prob}(z 0) R_{F}^{-1} E(z \mid z>0)
$$


Essa expressão sempre apresentará valores positivos o que demonstra que a regra 'custo ou mercado, dos dois o menor' é conservadora.

Esse tipo de conservadorismo não é capturado na dinâmica informacional linear do modelo de OHLSON. A regra acima produz mudanças bruscas nos valores do resultado dependendo dos valores de $z$. Dessa forma, reconhece-se uma limitação do modelo de OHLŚSN para esse tipo de conservadorismo.

O próximo, e último exemplo, caracteriza o conservadorismo contábil como a depreciação acelerada de ativos. Isso significa que a depreciação contábil está sendo feita de forma mais rápida do que a efetiva realidade econômica, produzindo valores excessivamente baixos para os ativos.

Finalmente, alguns conceitos apresentados por FELTHAM e OHLSON (1995) precisam ser introduzidos relativos às diferentes classes de ativos e fluxos de resultado presentes no modelo. Inicialmente, assume-se que a empresa não possui outra fonte de recursos além daquela representa pela integralização de capital pelos proprietários. Assim, o valor do patrimônio líquido pode ser dividido entre ativos financeiros e operacionais:

$$
P L_{T}=A F i n_{T}+A O p_{T}
$$

Da mesma forma, o resultado contábil pode ser dividido entre lucro operacional e financeiro:

$$
\operatorname{LuC}_{T}=\mathrm{LuCFin}_{T}+\mathrm{LuCOp}_{T}
$$

Assume-se que o lucro financeiro (LucFinT) é auferido pelos ativos financeiros $\left(A F i n_{T}\right)$ da seguinte forma:

\footnotetext{
${ }^{28}$ Essa consideração é análoga à regra 'preço ou mercado, dos dois o menor' normalmente aplicada na
} 


\section{$\operatorname{LucFin}_{\mathrm{T}}=(\mathrm{RF}-1) \mathrm{AFin}_{\mathrm{T}-1}$}

Assume-se que a transferência de fluxos de caixa $\left(F C_{T}\right)$ dos ativos operacionais para os financeiros permite que cada classe de ativos possua sua própria clean surplus relation:

$$
A F i i_{T}=\text { AFini }_{T-1}+\text { LuCFin }_{T}+F_{T}-d_{T}
$$

e

$$
A O p_{T}=A O p_{T-1}+L u C O p_{T}-F C_{T}
$$

Finalmente, define-se o lucro anormal operacional (LuCAOp $p_{T}$ ) como:

$$
\operatorname{LuCAOp} T=L u C_{T}-\left(R_{F}-1\right) A O p_{T}
$$

e o processo estocástico para esses lucros anormais como:

$$
\text { LucAOp } p_{T+1}=\omega_{11} L u C A O p_{T}+\omega_{12} A O p_{T}+v_{T}+\varepsilon_{1 T+1}
$$

Onde $\omega_{11}$ e $\omega_{12}$ são ambos positivos e $\omega_{11}$ è menor do que 1. FELTHAM e OHLSON fornecem um resultado surpreendente neste momento: se $\omega_{12}>0$ o modelo contábil é conservador; se $\omega_{12}=0$ o modelo contábil é não viesado. Para facilitar o entendimento desse ponto, assume-se que $v_{T}=0$ para todos os valores de $t$ e $\omega_{11}=0$ de forma que ignorando-se os ativos operacionais, o resultado anormal operacional é um processo de ruído branco (white noise process). Se $\boldsymbol{\Phi}_{12}$ for positivo o resultado operacional anormal é parcialmente antecipável e aumentando de acordo com a base de ativos operacionais. Neste último caso o modelo contábil está subestimando a base de ativos da empresa. Somente 
quando $\Phi_{12}=0$ o montante de ativos operacionais está sendo mensurado adequadamente.

Os tópicos relacionados nas seções acima sumarizam o modelo de OHLSON dentro de sua dinàmica informacional. A próxima seção apresenta as principais propriedades dos números contábeis relevantes para este trabalho que podem ser extraidas da abordagem de OHLSON.

\subsection{Propriedades Esperadas da Informação Contábil dentro da Especificação de Ohlson}

Segundo o exposto por OHLSON (1995) e FELTHAM E OHLSON (1995), conforme apresentado acima, pode-se extrapolar algumas propriedades dos números contábeis. Inicialmente, é importante a apresentaçăo de uma particularidade adicional do modelo. O modelo ganhou notoriedade na literatura contábil porque ele se situa em uma esfera intermediária entre abordagem da informaçāo e a da mensuração. O trabalho de OHLSON (1995) e FELTHAM e OHSLON (1995) concilia essas duas abordagens dentro de uma estrutura única.

O aspecto de mensuraçăo do modelo é obvio uma vez que ele propōe uma especificaçāo para-se chegar aos preços de mercado por intermédio de variáveis contábeis. O conteúdo informacional do modelo, no entanto, é subliminar e muitas vezes não è notado nos trabalhos a respeito do modelo de OHLSON (LUNDHOLM, 1995 e BERNARD, 1995, por exemplo, nem mesmo citam tais consideraçōes). O modelo assume que nāo existem oportunidades para arbitragem (P1) o que naturalmente requer que o mercado seja eficiente em termos informacionais. Dentro da abordagem proposta, as variáveis contábeis (denotando-se por $x_{\pi}$ as variáveis contábeis de relevância para simplificar a análise) devem explicar o comportamento do valor intrinseco da empresa (denotado por $V_{\pi}$ formado pelo valor presente dividendos futuros). Assim o 
objetivo da pesquisa dentro dessa abordagem pode ser definido como a estimação dos fatores da seguinte regressão:

$$
E\left(V_{\pi} \mid x_{\pi}\right)=\alpha_{T}+\beta_{T} x_{\pi}
$$

No entanto, assumindo-se que o preço de mercado $P_{\pi}$ desvia-se do valor intrínseco por um erro de mensuraçäo $\varepsilon_{i T}$ :

$$
P_{i T}=V_{\pi}+\varepsilon_{\pi}
$$

Substituindo-se $V_{I r}$ na equaçāo anterior tem-se:

$$
E\left(P_{i T} \mid x_{\pi T}\right)-E\left(\varepsilon_{\pi} \mid x_{\pi}\right)=\alpha_{T}+\beta_{T} x_{\pi}
$$

Se o mercado for eficiente em relação a informação $x_{i r}$ então $E\left(\varepsilon_{\pi} \mid x_{i}\right)=0$ e as regressōes do preço ou retorno (como variáveis dependentes) nos números contábeis como variáveis independentes pode ser feita sem maiores problemas. No entanto, se o mercado financeiro em questāo não for eficiente em relação à informação contábil tal especificação nāo mais será válida devido a ausência de um tratamento adequado do termo de erro.

Esse aspecto é, de forma sucinta, o conteúdo informativo do modelo de OHLSON. Assim, pode-se analisar os resultados das especificaçōes tradicionais (regressōes lineares como as utilizadas neste trabalho) como medidas da eficiência dos preços de mercado em termos do conjunto de informaçōes contábeis. Os resultados encontrados nas regressöes indicaram quais os itens mais importantes para explicar o comportamento dos preços dentro da abordagem utilizada.

Finalmente, cabe localizar o trabalho dentro da literatura de economia financeira. OHLSON e BUCKMAN (1980), em um trabalho seminal (Toward a 
Theory of Financial Accounting. Journal of Finance, Vol 35, No.2), resumem claramente as alternativas de pesquisa em contabilidade financeira:

"...the purpose of information is to facilitate and improve upon the consuption investment plans of individuals transacting in a market setting. This must be viewed as a very weak requirement since it simply means that somewhere along the line (accounting) information has to be related to individuals' well being. Naturally, a major research implication will then be one of investigating the effects of information and, changes in information, on the welfare induced by the resulting allocation (s) of goods. Classically, economics has utilized two basic concepts to analyze and compare the outcomes of any (changes of) economic mechanism (s).

First, alternative notions of efficiency have been used to describe "benchmark" characteristics of economies which are typically judged to be more or less desirable. Loosely speaking, these efficiency concepts satisfy different kinds of economy-wide optimality conditions. In models involving uncertainty, there are currently three concepts in use: full Pareto efficiency (generally atributed to Arrow in uncertainty models); constrained Pareto efficiency ... ; and social Nasch optimality.

A given allocation is said to be fully Pareto efficient with respect to a specified information strucuture if it is Pareto efficient with respect to all allocations outside of the market setting (i.e., irrespective of the combination of trading arrangement and securities-state tableau). A given allocation is said to be constrained Pareto efficient with respect to a particular information structure if it satisfies a set of constraints restricting transfers between individuals across states and goven these constraints is Pareto efficient. Fully Pareto efficient allocations 
are not constrained in such a fashion and as a result are never Pareto inferior to an allocation which is constrained Pareto efficient. The condition of social Nash optimality is difficult to explain without considerable overhead. Suffice is to say that if the allocations chosen are not coordinated across potential messages then these allocations will be less efficient than they otherwise might be. Thus these allocations will satisfy some but not all optimality conditions."

Conforme comentado acima, o modelo apresentado neste trabalho e a sua subsequente aplicação empírica não encaixam-se em nenhuma das análises apresentadas acima. No entanto como os próprios autores, OHLSON e BUCKMAN (1980:544), mostram:

"...the effects of information on an individual's wealth level constitutes another dimension by which the allocative outcomes associated with different economic regimes and/or alternative information strucuture could be compared and evaluated. In fact, much of the empirical research investigating the effect of various accounting alternatives on security prices could be interpreted as attempts to ascertain the effect of accounting information on investor wealth."

Dessa forma, a pesquisa empirica em contabilidade financeira pode ser encaixada dentro deste paradigma. A análise do impacto da contabilidade nos preços negociados em mercado de capitais é uma tentativa de verificar como a riqueza dos investidores é afetada pela contabilidade. É dentro desse paradigma que este trabalho se coloca. Nesse sentido, a perspectiva da informaçāo e a abordagem da mensuraçāo precisam ser integradas, pois ambos os conceitos impactam o bem estar dos acionistas. OHLSON e BUCKMAN (1980:544-545) complementam: 
"For example, the first issue of Journal of Accounting and Economics contains two articles which analyse full cost accounting versus successful efforts accounting. With some oversimplification, the issue is to what extent (if at all) a switch in accounting principle affects shareholders' wealth because of changes in stock prices. If this effect is present, then this might suggest that they are worse off and that the accounting switch is undesirable from the shareholders' point of view. Thus the perspective taken here is that research in accounting should assess the effect of information both in terms of the allocation efficiency attained and in terms of the utility levels achieved by the market participants in various settings of information and markets."

$\mathrm{Na}$ próxima seção serão apresentados os principais estudos da literatura em contabilidade financeira que são relevantes para os objetivos deste estudo. 


\section{REVISÃO DA LITERATURA}

O papel da informação contábil para explicar o comportamento dos preços no mercado financeiro tem sido uma longa e ampla área de pesquisa nos últimos 30 anos. Esta revisāo da literatura tem como objetivo a apresentação dos principais métodos utilizados na tentativa de entender o comportamento dos preços em relaçāo à informação contábil bem como dos principais resultados. Esta revisão é relativamente extensa, porém não exaustiva, refletindo a quantidade de material produzida nesse campo de investigação cientifica. Alguns dos tópicos abordados não estão relacionados diretamente ao objeto de estudo do trabalho, mas sāo necessários para que seja possivel o entendimento da evoluçāo da pesquisa e da localização conceitual do trabalho realizado dentro da literatura.

Este capitulo está dividido em 4 seçōes: (i) estudos gerais relacionando a informação contábil e o mercado de capitais, (ii) estudos de eficiência de mercado, (iii) estudos do papel da contabilidade em mercados menos desenvolvidos e (iv) governança corporativa e contabilidade. A escolha desses tópicos esta diretamente relacionada com os objetivos do trabalho. O primeiro tópico apresenta os estudos pioneiros e introdutórios relacionando informação contábil e preços. Em seguida os itens 2 e 3 mostram como tais estudos foram expandidos para considerar questōes relativas à eficiència do mercado financeiro sob análise e também como preços reagem à contabilidade em mercados financeiros menos desenvolvidos e não tão sofisticados como aqueles tradicionalmente considerados pela literatura. $O$ item 4 merece uma observação especial. Como será visto, muito recentemente alguns autores começaram a correlacionar estruturas gerais (nacionais) e especificas(empresa por empresa) de governança corporativa com propriedades da informação contábil. Alguns autores defendem que as propriedades dos números contábeis dependem do modelo de governança, 
enquanto outros admitem que a contabilidade pode determinar, pelo menos parcialmente, as práticas de governança. A inclusão desse item aumenta o conteúdo teórico do trabalho e fornece argumentos para a extensão das conclusōes dos estudos realizados.

No entanto, antes de iniciar a revisäo da literatura diretamente relacionada com a contabilidade e o mercado de capitais, è necessário uma introdução à literatura geral de economia financeira naquilo que se refere aos aspectos de informação. A hipótese do mercado eficiente começou a ser usada para descrever mercados onde os preços refletem completamente a informaçāo disponivel (FAMA, 1970). FAMA classificou três niveis de eficiência: forte, semi-forte e fraca. Esses niveis estāo relacionados ao conjunto de informação que está refletido nos preços. Na forma fraca os preços refletem completamente a informaçāo contida nos preços passados. $\mathrm{Na}$ forma semi-forte os preços refletem toda a informação pública disponivel. Na forma forte os preços refletem totalmente a informaçāo existente, seja pública ou privada. A literatura na forma fraca pode ser vista em BACHELIER (1900) que conclui que o preço corrente de uma commodity è um estimador nāo viesado do seu preço futuro. O conceito de randon walk (caminho aleatório) é consistente com o trabalho de BACHELIER. Mais de meio século depois os trabalhos de ROBERTS (1959) e OSBORNE (1959) mostraram que o comportamento dos preços de açōes negociadas em bolsas de valores poderiam ser adequadamente descritos segundo o modelo de randon walk. Esses trabalhos foram seguidos por GRANGER e MORGENSTEIN (1963), MOORE (1964) e FAMA (1965) que forneceram suporte para a descrição do comportamento dos preços como randon walk. SAMUELSON (1965) mostrou que preços possuem comportamento aleatório com a taxa de retorno sendo considerada uma variável exógena. LEROY (1973) demonstrou que se as taxas de retorno forem determinadas em equilibrio os preços dependeriam do risco do projeto e também das preferèncias dos investidores. Dessa forma, os retornos esperados não precisam ser independentes para caracterizar a eficiência dos mercados. 
Os testes mais utilizados para avaliar a forma fraca são os testes de correlaçāo serial, filter rules tests e testes cíclicos. Os testes de correlação serial determinam a associaçāo entre dois elementos em uma série de tempo separados por um número constante de periodos (time series moving window). Evidèncias fornecidas por ROSEMBERG e RUDD (1982) indicam que a autocorrelaçāo serial de primeira ordem entre residuos de retorno diários advindos do modelo de mercado $\left(R_{l}=\alpha_{i}+\beta_{i} R_{m}+u_{1}\right)$ era pequena, mas significativamente negativas. Essa evidência, contrária a eficiència no forma fraca, pode ser explicada pela presença de market makers e todos os problemas de microestrutura como spreads de compra e venda, preços discretos e nāo contínuos, momento da coleta dos preços, etc. Os testes relacionados com regras de filtragem utilizam regras específicas de operação como estratégias para compra e venda de títulos. A predominància de uma estratégia baseada em informações passadas gerando resultados anormais é evidência de ineficiência. ALEXANDER (1961) apresentou retornos anormais utilizando estratégias contrárias em intervalos curtos sem considerar custos de transaçāo e FAMA (1965) e FAMA e BLUME (1966) mostraram que os resultados anormais apresentados eram devidos a custos de transaçāo. LEVY (1967) apresentou retornos anormais utilizando a razāo entre o preço atual das açōes e sua média mensal. Esses resultados foram considerados metodologicamente incoerentes por JENSEN (1967) e JENSEN e BENNINGTON (1970) devido a existência de viés na seleção da amostra. BEAVER e LANDSMAN (1981) demonstraram a inexistência de resultados anormais utilizando uma regra baseada em vencedores e perdedores em termos de retorno em um dado período de tempo. Estudos cíclicos utilizam-se de análise espectral para testar 0 comportamento ciclico em séries de tempo. Alguns estudos demonstram retornos menores na Segunda-feira quando comparada com outros dias da semana (CROS, 1973; FRENCH, 1980; GIBBONS e HESS, 1981) e também em Janeiro quando comparado com outros meses (BONIN e MOSES, 1974; ROZEFF e KINNEY, 1976) fornecendo evidèncias de que existe um componente ciclico nos retornos em mercados de capitais. No entanto, a maior parte dessas evidèncias foi revista quando LAKONISHOK e LEVI (1982) mostraram que esses efeitos eram 
relacionados a características operacionais dos mercados e a utilização de retornos nāo ajustados ao risco. A correçāo desses fatores levam ao desaparecimento das anomalias.

A forma semi-forte implica que toda a informação pública está refletida nos preços e que os preços ajustam-se rapidamente e de forma não viesada a anúncios públicos de informaçăo. Nesse cenário resultados anormais não podem ser obtidos com a negociaçāo baseada na publicação de balanços, por exemplo. Muitos estudos foram realizados para verificar como os preços reagem a anúncios de splits, negociaçōes em bloco(grande número de açōes), anúncio de dividendos, variáveis macoreconómicas, etc. FAMA, FISHER e ROLL (1969) encontraram grandes retornos anormais acumulados antes de splits e não depois destes. SCHOLES (1972) mostrou que vendas em bloco significam informaçōes negativas para o mercado e este normalmente nāo retorna aos níveis anteriores de preço. KRAUS e STOLL (1972) e GRIER e ALBIN (1973) encontraram evidências que é possivel a realização de retornos anormais por intermédio da compra de açōes após negociaçōes em bloco e venda subsequente. Esses resultados, no entanto, ficam restritos a intervalos de tempo bastante reduzidos como demonstram CAREY (1977) e DANN, MAYERS e RAAB (1977). Esses resultados demonstram que eficiència no sentido completo não é possivel dentro dos mecanismos de mercados presentes, mas que as ineficiências não permanecem por muito tempo.

Anúncios de dividendos tem sido uma grande controvérsia desde que MILLER e MODIGLIANI (1961) sugeriram que a politica de dividendos é irrelevante em um mundo sem impostos. Sob a ótica da informação, o anúncio de dividendos leva informaçāo ao mercado que deveria reagir rapidamente não apresentado oportunidades para resultados anormais. Da mesma forma, os preços das açōes deveriam cair pela mesma quantidade do pagamento dos dividendos. Evidências iniciais (PETIT, 1972; CHAREST, 1978) mostram que o mercado reage rapidamente ao anúncio de dividendos. No entanto, a existência de um grande número de investidores com regimens tributários diferentes pode 
criar alguns problemas para a eficiência de mercado em relaçăo aos dividendos. Existem fortes evidências de que os preços não caem realmente $100 \%$ do valor dos dividendos pagos quando do anúncio destes refletindo, possivelmente, regimes tributários diferentes. De acordo com ELTON e GRUBER (1970) a queda nos preços é de aproximadamente $78 \%$. Esses resultados fornecem oportunidades para investidores realizarem arbitragem entre o preço das açöes antes e depois do pagamento de dividendos.

Dentro da arena macroeconômica, HOMA e JAFFE (1971) apresentaram resultados mostrando que a oferta de dinheiro poderia ser uma proxy para a realização de resultados anormais. Estudos subsequentes (MALKIEL e QUANDT, 1972; PESANDO, 1974; COOPER, 1974; ROZEFF, 1974) demonstraram que esses resultados iniciais possuiam problemas metodológicos e eram, basicamente, devidos a relaçōes instáveis entre preços e variáveis monetárias. É importante notar que mercados podem apresentar correlaçōes seriais e ainda assim serem eficientes. Um dado mercado é considerado ineficiente quando é possivel a realização de resultados acima da remuneraçāo pelo risco dos titulos. No entanto, informaçōes podem ser obtidas por intermédio da observaçāo das características e organização dos mecanismos de negociação. Suspensão de negociação (circuit break) e lançamento de novos papéis (initial public offer) são exemplos de imperfeiçōes do mercado. HOPEWELL e SCHWARTZ $(1976,1978)$ e KRYZANOWSKI (1979) mostraram que os mercados reagem eficientemente a boas notícias (good news) mas não ajustam-se completamente para más notícias, no caso de suspensão de negociação e venda descoberta (bad news). MCDONNALD e FISHER (1972) mostraram que resultados anormais são percebidos por subscritores iniciais de titulos e que os preços de mercado ajustam-se dentro de uma semana. Esse fenômeno é causado por desconto no preço de venda para garantir subscriçāo total.

Ainda na análise da foram semi-forte, BANZ (1981) mostrou que pequenas empresas pequenas possuem retornos anormais mais freqūentemente que 
grandes empresas. Outros autores como ROLL (1981), SCHOLES e WILLIAMS (1977) e REIGANUN $(1981,1982)$ tentaram explicar esse fenômeno em termos de estimativa incorreta (misestimation) do risco sistemático nos modelos de precificação subjacentes devido a caracteristicas de negociação dessas pequenas empresas. No entanto, os resultados destes estudos nāo foram convincentes. KEIM (1983) e ROLL (1983) demonstraram que parte desse "efeito pequenas empresas" (small firm effect) eram relativos a periodos determinados de tempo no inicio e final de cada ano. Esse resultado sugere um efeito tributário com a desvalorização de preço das empresas perto do final do ano tributário. De acordo com DYL (1977) essa explicaçāo possui forte evidência empírica e parece explicar o fenômeno; este autor observou que empresas que apresentaram resultados ruins durante o ano eram mais negociadas em Dezembro em relaçāo à empresas que apresentaram bons resultados durante $\circ$ ano. Esse e outros estudos (BRANCH, 1977; ROLL, 1973) não apresentam sucesso ao tentar explicar o efeito das pequenas empresas, especialmente durante o restante do ano. BROWN, KLEIM, KLEIDOM e MARSH (1983) observaram retornos anormais para pequenas empresas na Austrália durante o mês de Janeiro na Austrália onde o ano fiscal termina em Junho. Uma explicaçāo para esse fenômeno é apresentada por ARBEL e STREBEL (1983) que mostram que firmas que não são acompanhadas de perto por analistas apresentam retornos maiores do que firmas que sāo acompanhadas mais extensivamente. Este resultado é inconsistente com o CAPM (Capital Asset Pricing Moden que determina que somente o risco não diversificável deve ser remunerado. Assim, aparentemente, os investidores demandam retornos maiores para empresa que nāo sāo suficientemente conhecidas. STOLL e WHALEY (1983) apresentam evidèncias de que esse efeito pode ser relacionado com maiores custos de transaçāo na negociação de pequenas empresas. REINGANUM $(1981,1983)$ e BASU (1983) apresentam evidèncias empíricas de correlaçāo positiva entre indices preço/lucro e o tamanho das empresas. 
Segundo a hipótese do mercado eficiente não é necessário tempo para que analistas processem informaçăo e fornecem aconselhamento para clientes. No entanto, BLACK (1973) e COPELAND e MAYERS (1982) fornecem evidências que as recomendações da empresa Value Line foram suficientes para que seus clientes realizassem resultados anormais. Da mesma forma, GIVOLY e LAKONISHOK (1979) mostraram que resultados anormais podem ser obtidos após revisōes otimistas realizadas por analistas. Outros estudos (DAVIES e CANES, 1978; FOSTER, 1979) mostram forte correlaçāo entre os relatórios dos analistas (artigos, relatórios, etc.) e resultados anormais positivos e negativos. Esses resultados juntamente com outros mostrando que os preços reagem exageradamente (overreaction) ao İndice de Preços ao Consumidor (Consumer Price Index) são fortes evidências contra a hipótese do mercado eficiente (SCHEWERT, 1981). Essas evidências sāo particularmente fortes no dia da publicação de recomendaçōes de analistas.

Sob a hipótese de eficiência na forma forte, todas as informaçōes, sejam públicas ou privadas, estāo refletidas nos preços. Informaçōes privadas (ou privilegiadas) nāo sāo sưficientes para a realizaçāo de resultados anormais. Essa hipótese é bastante ampla e dificil de ser aceita intuitivamente. No entanto, algumas características do mercado, como a competiçāo entre agentes informados e não informados, podem fazer com que toda a informação acabe por ser refletida nos preços. Isso ocorre porque os agentes menos informados podem usar os próprios preços como fonte de informaçāo sobre os comportamento dos agentes informados (seguidores de preços) fazendo com que a informaçāo privada seja refletida nos preços. Essa forma é difícil de ser testada uma vez que a informação privada nāo é observável. Alguns autores (SHARPE, 1966; JENSEM, 1968) examinaram o comportamento de grandes fundos mútuos de investimento que, em tese, possuem mais informaçōes do que investidores particulares. Nenhuma evidência foi encontrada que favorecesse essa hipótese. Outros pesquisadores (LORIE e NIEDERHOFFER, 1968; JAFFE, 1974; FINNERTY, 1976) examinaram a atuaçăo de insiders (investidores com 
informações privilegiadas) segundo o relatório da SEC (Securities and Exchange Commission, Comissão de Valores Americana) SEC's Official Summary. Os resultados encontrados mostram que as estratégias dos insiders apresentaram resultados anormais, sendo contrários à hipótese dos mercados eficientes na forma forte.

A reação dos preços antes do anúncio dos resultados contábeis é conhecido como vazamentos (leaks). No entanto, não está claro se esses vazamentos ocorrem por intermédio de canais públicos ou privados. MORSE (1980) afirma que um volume maior de negociaçāo é esperado se a informaçāo for disseminada por intermédio de canais privados. Os resultados encontrados mostram que o volume negociado é significativamente menor nos dias anteriores a grandes flutuaçōes de preços. Também sāo observados volumes maiores acompanhados por mudanças monotonicas nos preços. KEOWN e PINKERTON (1981) fornecem evidências de fenōmenos similares antes de anúncios de fusões e aquisiçōes. Esses resultados sugerem que os preços nāo refletem toda a informaçāo privada como previsto na hipótese forte e que é possivel a realizaçăo de lucros baseados em informaçōes privilegiadas.

A existència de oportunidades de arbitragem também nāo é consistente com a hipótese dos mercados eficientes. MANASTER e RENDLEMAN (1982) utilizam o modelo BLACK \& SCHOLES (BLACK e SCHOLES, 1973) para testar se os preços das opçōes possuem informaçōes sobre as açōes subjacentes. Esses autores encontraram evidências de que os preços das opçōes possuem informaçōes sobre as açōes que não estão refletidas imediatamente no preço destas. A explicação para essa anomalia é a maior eficiência nos mercados de opçōes em relação aos mercados de açōes. Outra anomalia refere-se ao desconto no preço das açōes de fundos mútuos fechados em relação à soma do preço das ações individuais. THOMPSON (1978) mostrou que é possivel a realização de lucros com arbitragem entre as açōes desses fundos e as açöes correspondentes das empresas. 
Muitas empresas pagam um prêmio sobre o preço de mercado para compra outras empresas. Se a hipótese dos mercados eficientes for válida, essas empresas devem sofrer um queda de preço após a compra devido ao pagamento em excesso. MANDELKER (1974), ASQUIT e KIM (1982) e BRADLEY (1980) mostram que esse declínio não ocorre como esperado. Outros autores (DODD e RUBACK, 1977; DODD, 1980) mostram que esse prêmio é devido a informações privilegiadas que apontam que a empresa está sub-avaliada. Eles demonstram que após tentativas mal sucedidas de fusāo o preço da empresa é corrigido o que confirma a hipótese da presença de informaçāo privada. Essas evidencias são inconsistentes com a hipótese do mercado eficiente na forma forte. SCHILER (1981), LEROY e PORTER (1981) introduzem a idéia de que os investidores podem reagir exageradamente a novas noticias (overreaction) de forma que a volatilidade dos preços não refletem adequadamente as variáveis subjacentes, como dividendos.

Em resumo, esses estudos iniciais tentando testar a eficiência dos mercados em relaçāo a informaçōes não contábeis fornecem evidências que, pelo menos no mercado de capitais americano, a forma fraca prevalece. Esses resultados não são consistentes como a forma forte, definitivamente. Em relação a forma semi-forte os resultados dependem do conjunto de informaçōes analisados. Cabe ressaltar, no entanto, que, como observam CAMPBELL et all (1997:24):

"Although the empirical methodology summarised here is wellstabilished, (referindo aos event-studies, que são a base dos trabalhos sumarisados acima) there are some serious difficulties in interpreting its results. First, any test of efficiency must assume an equilibrium model that defines normal security returns. If efficiency is rejected, this could be because the market is truly inefficient or because an incorrect equilibrium model has been assumed. This joint 
hypothesis problem means that market effciency as such can never be rejected."

Assim, todos os estudos relativos à eficiência do mercado possuem esse tipo de limitação. Como pode ser visto no capitulo 2, seção 2.5 , a opção desta tese por estudos utilizando o modelo de OHLSON como base de mensuração, evita esse tipo de questionamento, conforme apresentado acima.

Mais recentemente, HAWAWINI e KEIM (2000) mostram que os betas ${ }^{29}$ dos ativos não explicam diferenças entre retornos médios de açōes (cross-section). $\mathrm{Na}$ realidade, muitas variáveis que nāo possuem base na teoria parecem ter maior poder explicativo do que os betas. Esses autores concluem que um modelo multivariado é necessário para explicar o comportamento inesperado dos preços. Outros autores como FAMA e FRENCH (1992) sugerem um modelo de precificaçăo de três fatores (three-factor equity-pricing-model) com o tamanho da empresa e a situaçāo financeira como variáveis explicativas em adição ao beta. Outros autores sugerem outro fator: retorno anterior. HAWAWINI e KEIM (2000) mostram que estes resultados ad hoc (sem base na teoria) sāo derivados principalmente do mês de Janeiro e não sāo correlacionados internacionalmente. Assim, verifica-se uma anomalia: resultados empiricos sem base teórica. KOTHARI e SHANKEM (2000) enfatizam que a aceitação dessas variáveis ad hoc é prematura e que maiores evidências empiricas são necessárias. Esse aspecto do comportamento dos retornos desperta enorme controvérsia com BERK (2000) sugerindo que não existe anomalia, uma vez que os resultados nāo são fortes (robustos) o suficiente para prever relaçōes inversas. No entanto, DIMSON e MARSH (2000) mostram que o "efeito tamanho" (size effect) è relevante. A única conclusão que se pode atingir neste momento é que muita pesquisa ainda é necessária para que se possa verificar claramente a relação do comportamento do preço dos titulos e outras variáveis de mercado. Pesquisa teórica em condiçōes de equilibrio com assimetria de informação para ser um caminho a ser traçado.

\footnotetext{
${ }^{29} \mathrm{Bj}, \mathrm{m}=\operatorname{Cov}(\mathrm{Ri}, \mathrm{Rm}) / \sigma^{2} \mathrm{~m}$
} 
Recentemente, os modelos de comportamento (behavioral models) começaram a ser investigados com maior cuidado. Alguns autores argumentam que os investidores comportam-se de forma incompativel com os axiomas centrais da racionalidade (transitividade e dominância) e são exageradamente confiáveis em suas habilidades, reagindo com exagero a informaçōes privadas e lentamente a informaçōes públicas. DEBONDT (2000) argumenta que esse comportamento pode traduzir-se em tendèncias (momentum) e reversão à média nos retornos das açōes. Essa linha de pesquisa fornece explicações alternativas para algumas das anomalias encontradas na literatura. No entanto, essa área ainda é embrionária e demanda maiores pesquisas para formar um corpo teórico consistente.

Paralelamente aos estudos relacionados às anomalias em retornos dentro da perspectiva cross-section, alguns autores encontraram evidèncias de que as propriedades dos retornos em séries de tempo também são inconsistentes com o modelo de randon walk. Também nessa área, as anomalias mais importantes estāo relacionadas a periodos especificos de tempo: inicio do ano, mês e semana. KEIM (1983) e ROZEFF e KINNEY (1976) documentaram evidèncias relacionadas com o efeito Janeiro. Da mesma forma, CROSS (1973) e FRENCH (1980) mostraram o "efeito segunda-feira". ARIEL (1990) apresentou resultados mostrando que um terço do retorno durante o periodo 1963-82 foi obtido nos dias de úteis que precederam os oito feriados existentes nos Estados Unidos. Recentemente BOOTH e KEIM (2000) documentaram que o "efeito Janeiro" ainda é presente e as forças de mercado não são suficientes para eliminar um efeito tão bem documentado. HENSEL e ZIEMBA (2000) mostraram o efeito Janeiro nos indices de açōes é antecipado nos mercados futuros em Dezembro de forma que é possivel a realizaçāo de resultados anormais. HENSEL e ZIEMBA (2000) mostram que os retornos nas administraçōes Democratas são maiores do que nas administraçōes Republicanas, especialmente nos dois últimos anos. Da mesma forma, GRINBLATT e KEIM (2000) mostram a presença de retornos anormais 
após anúncio de splits e dividendos. Esses resultados são claramente anomalias ao conhecimento teórico de finanças possuído atualmente.

Internacionalmente, algumas evidências interessantes são apresentadas pelas características dos retornos das açōes. Como KEIM e ZIEMBA (2000; pg. xxii) comentam:

Such differences can provide valuable new insights into the nature of these phenomena and hopefully, expedite the search for explanations."

A importância de evidências advindas de mercados não tão desenvolvidos como o americano podem trazer grandes contribuiçōes para um entendimento mais completo do comportamento de preşos. ATHANASSAKOS e FOSTER (2000) encontraram similaridades nos mercados canadenses e americanos em termos das anomalias. CARNESTRELLI e ZIEMBA (2000) encontraram evidèncias do "efeito final do periodo" na bolsa de valores de Milāo. Na bolsa de valores de Tóquio, COMOLLI e ZIEMBA (2000) encontraram evidências do efeito final de periodo da mesma forma que nos Estados Unidos. MURADOGLU (2000) fornece uma discussão extensiva da bolsa de valores de Istambul e demonstra que muitos das anomalias encontradas nos mercados mais desenvolvidos sāo comuns ao mercado turco. As mesmas anomalias são encontradas em Helsinque de acordo com MARTIKAINEN (2000). PATEL (2000) fornece fortes evidências do "efeito tamanho" em 22 mercados emergentes (incluindo o Brasil) classificados de acordo com o International Finance Corporation Global Index. No entanto, esses resultados não são correlacionados entre os 22 mercados analisados da forma que HAWAWINI e KEIM (2000) apresentam para os mercados desenvolvidos. As mesmas anomalias são encontradas na Asia de acordo com $\mathrm{KOH}$ e WONG (2000). 
Esse grande montante de evidências empiricas sobre o comportamento de preços em mercados desenvolvidos e não desenvolvidos apresentam alguns pontos em comum: (i) certas anomalias são comuns aos mercados emergentes e aos desenvolvidos sugerindo que fatores comuns são responsáveis pelo fenômeno sem maiores conotaçōes culturais; (ii) essas evidências, apesar de robustas do ponto de vista estatístico, não possuem contrapartida teórica; (iii) finalmente, a presença de anomalias não pode ser desconsiderada em trabalhos futuros. Esses aspectos devem fazer parte da agenda de pesquisas nos próximos anos para que os resultados possam ser integrados do ponto de vista teórico.

Esses resultados na literatura de economia financeira trazem algumas questões interessantes para a contabilidade. Existem anomalias relacionadas à informação contábil? Essas anomalias, se existentes, dependem de caracteristicas especificas dos mercados? A relevância da contabilidade é dependente dos mercados em análise? A contabilidade é relevante? Esses são justamanete os aspectos abordados nessa dissertação. A seçāo seguinte aborda a literatura nesses tópicos com o intuito de loacalizar a dissertação dentro do corpo teórico existente focando as limitações dos trabalhos realizados até o momento e a contribuição desta dissertaçāo.

\subsection{Informação Contábil e Mercados Financeiros}

A literatura empirica abordando a relação entre a contabilidade e o mercado financeiro foi iniciada com o trabalho seminal de BALL e BROWN (1968) (BB de agora em diante). Esses autores analisaram a reaçāo dos preços de mercado à evidenciação de lucro contábil anormal. Baseados em estimativas, eles estudaram a reação dos preços a boas (lucro acima das expectativas) e más (lucro abaixo das expectativas) noticias. As evidèncias demonstram que os resultados anormais começam a crescer alguns meses antes dos anúncios de lucros. Os autores atribuem esse resultado a existèncias de outras fontes de informaçāo sobre o desempenho da empresa além da contabilidade. Exatamente na data do anúncio 
eles encontraram retornos anormais em torno de 7.5.\%. Outro trabalho clássico, contemporânes ao de BB, é o de BEAVER (1968). Ele estudou o comportamento dos preços e do volume negociado nas semanas próximas da divulgação de informações contábeis. Esse estudo demonstrou que tanto o preço como o volume negociado reagem fortemente à informação contábil, principalmente na semana dos anúncios.

Esses dois trabalhos inauguraram uma "nova era" na pesquisa em contabilidade baseados na associação entre a informação contábil e os preços no mercado financeiro. A contabilidade passou a ser vista como uma fonte de informaçōes para os usuários podendo ser analisada dentro do arcabouço econômico tradicional e nāo mais como um campo particular. A divisāo dos tópicos reflete a visāo do autor acerca dos aspectos mais importantes para a literatura e para este trabalho em particular.

\subsubsection{Conteúdo Informativo do Resultado}

BEAVER, CLARKE e WRIGHT (1979) estenderam o trabalho de BB no sentido da incorporaçāo do impacto da magnitude dos lucros nos preços. Esses autores mostraram que a mudança residual percentual dos resultados e nos lucros são positivamente correlacionadas. A interpretaçāo é que os mesmos fatores que influenciam o comportamento do resultado do exercício impactam os preços. Uma interpretação mais moderna e mais ambiciosa, é que os investidores comportamse como se o resultado contábil fornecesse informaçōes sobre o valor econômico da empresa (BEAVER, 1998). No mesmo sentido, BROWN e KENELLY (1972) expandiram o trabalho de $\mathrm{BB}$ incluindo resultados quadrimestrais, encontrando resultados similares. MAY (1971) e KIGER (1972) encontraram os mesmos resultados que BEAVER para informaçōes quadrimestrais. No mesmo caminho, MORSE (1981) encontrou grandes reaçōes de preço e volume utilizando informaçōes diárias até dois dias após a data do anúncio. Esse autor mostra que os preços respondem rapidamente, no entanto, algum tempo é necessário para 
que eles retomem ao nivel anterior. A conclusão de que variações residuais percentuais no resultado estão correlacionadas. com variaçōes residuais percentuais nos preços tornou-se um dos pilares dessa literatura. No entanto, em todos os estudos realizados esta correlação é menor do que 1. Segundo BEAVER (1998) duas razões existem para esse fenômeno: (i) alguns eventos afetam os preços mas não afetam o resultado contábil, mesmo no longo prazo; (ii) o mercado diferencia componentes transitórios dos permanentes nos lucros, reagindo somente àquela parcela do lucro que realmente reflete a capacidade da empresa de gerar resultados econômicos futuros. Esses resultados refletem o fato de que, apesar de fontes de informaçāo importantes, o resultado compete com outras informaçōes no mercado como anúncios de litígios, fusōes e aquisiçōes, desenvolvimento de novos produtos e pesquisas, etc. Outras mudanças no resultado podem ser advindas de alterações de métodos e práticas contábeis, como o método de depreciação, que, salvo por efeitos tributários, não possuem impactos na capacidade de geraçāo de caixa da empresa. Mudanças de métodos e práticas contábeis sem impacto na capacidade de geraçāo de caixa da empresa não deveriam, pelo menos em tese, impactar os preços.

Atençăo especial tem sido dada aos componentes transitórios do resultado. Esses componentes afetam o resultado corrente mas nāo impactam resultados futuros. Lucro na venda de ativos imobilizados, por exemplo. BEAVER e MORSE (1978) mostram que empresas que apresentam indices preço/lucro altos no final de um ano tiveram crescimento modesto de lucro neste ano e grande crescimento do lucro no ano subsequente. $O$ oposto também é verdade para empresas que apresentaram baixos indices preço/lucro em um dado ano, com grande crescimento no lucro neste ano e crescimento modesto no ano seguinte. Esse resultado corrobora a idéia de que o mercado percebe componentes transitórios no lucro. Esses componentes transitórios induzem uma correlaçāo positiva entre o indice preço/lucro em um dado ano e o crescimento do lucro no ano seguinte. Quando o lucro está temporariamente baixo, devido a elementos transitórios como disputas judiciais, o indice preço/lucro estará alto neste ano e o crescimento do 
lucro será alto no ano seguinte. Esse comportamento foi documentado por PENMAN (1996). O coeficiente de resposta do preço às flutuaçōes no resultado dependem de fatores como tamanho da firma, nivel de crescimento, taxas de juros, etc, como documentado por HAYAN(1995), COLLINS, MAYDEW e WEISS (1997), KORMENDI e LIPE (1987), EASTON e ZMIJEWISKI (1989) e COLLINS e KOTARI (1989).

PATEL e WOLFSON $(1979,1981)$ inauguraram outra metodologia para o teste do conteúdo informativo do resultado. Eles mostraram que antes do anúncio de resultados, os preços das opçōes das açōes correspondentes aumenta implicando que os investidores percebem uma maior volatilidade no preço das açōes próximo ao anúncio dos resultados. Esse resultado deve-se à relaçāo entre a volatilidade na açāo objeto e o preço das opçōes.

Apesar desses resultados, alguns autores como LEV (1989) afirmam que:

“...while earnings appear to be used by investors, the extent of earnings usefulness is rather limited."

Essa conclusāo è baseada na correlaçāo fraca e instável entre retorno de açōes e resultados contábeis. $O$ autor justifica essa afirmaçāo na baixa qualidade dos resultados contábeis e não em problemas metodológicos ou irracionalidade dos investidores. No entanto, uma revisāo geral da literatura nos leva a concluir que o resultado contábil é relevante mas possui baixo poder explicativo. A relevància dos resultados contábeis também depende de condiçōes gerais de funcionamento do mercado e do nivel de eficiència do mesmo. Como será visto adiante, é importante ressaltar que para esses autores o resultado contábil perde relevância em mercados menos desenvolvidos. 


\subsubsection{Resultado, Fluxo de Caixa e Accruals}

Alguns autores concentraram esforços, principalmente na fase inicial dessa pesquisa, na reação dos preços aos componentes de fluxo de caixa e accrual do resultado. BB mostraram que o fluxo de caixa residual não é tão bem sucedido como o resultado residual para prever alteraçōes nos preços das açōes. No entanto, WILSON $(1986,1987)$ mostrou que a evidenciaçāo subsequente de fluxo de caixa possui valor incremental sobre a evidenciaçāo de resultado. BERNARD e STOBER (1989) mostraram que o conteúdo informativo do fluxo de caixa e do resultado varia de acordo com condiçōes gerais da economia. SLOAN (1996) encontrou resultados contraditórios mostrando que o mercado nāo diferencia esses componentes do resultado.

Os resultados desse tipo de investigaçāo sāo extremamente importantes para a pesquisa e a própria prática em contabilidade uma vez que é esperado que - accrual forneça informaçōes adicionais ao fluxo de caixa. Espera-se que a presença de acrruals (como métodos de depreciaçāo e de reconhecimento de receitas e despesas) seja um mecanismo para que os administradores forneçam informações privadas sobre a empresa para o mercado. Assim, nāo é esperado que a evidenciação adicional do fluxo de caixa forneça informaçōes mais relevantes do que aquelas fornecidas pelo resultado. Como a presença de accruals é uma das caracteristicas fundamentais do modelo contábil, a verificaçāo de sua irrelevância coloca em dúvida a própria utilidade da contabilidade no contexto de mercado de capitais.

\subsubsection{Oportunidade ${ }^{30}$ (timeliness) do Resultado}

Desde os estudos iniciais, existem fortes evidèncias de que os preços säo capazes de antecipar grande parte do conteúdo informativo do resultado contábil. Essa antecipação ocorre por intermédio de reação anormal dos preços antes do 
anúncio dos resultados contábeis. Na realidade, os estudos mostram que somente $10 \%$ do resultado anormal ocorre no mês do anúncio. Esse resultado reflete a idéia que os preços são afetados por fontes de informação mais atualizadas do que os resultados. A entrada de um novo concorrente no mercado, por exemplo, afeta preços imediatamente mas pode demorar muitos periodos antes que os lucros apresentem tais impactos. O caso de provisionamento de despesas de litígios judiciais ainda nāo resolvidos, por exemplo, é um caso onde o modelo contábil tenta refletir, por intermédio do conservadorismo, a realidade econômica mais rapidamente. Alguns autores concluiram, precipitadamente, que o resultado contábil não é oportuno de forma nenhuma (BENSTON, 1976). No entanto, mesmo o trabalho pioneiro de BEAVER (1968) mostra que a volatilidade dos preços na semana do anúncio do resultado é $167 \%$ do valor médio encontrado durante o ano. Usando dados diários FOSTER (1986) encontrou uma alteração de preço residual pequena, mas estatisticamente significante, no dia do anúncio e no dia imediatamente anterior. Similarmente, PATEL e WOLFSON (1984) examinaram o comportamento dos preços usando dados durante o dia (intraday). Eles encontraram grande resposta dos preços na hora do anúncio. Estudos dessa natureza sāo extremamente importantes porque tratam de uma das mais importantes características qualitativas da informação contábil que está no cerne do arcabouço conceitual da contabilidade do FASB (FASB, 1978). Esses resultados mostram que, apesar dos argumentos de que o resultado contábil não possui oportunidade em termos do fornecimento de informaçōes, as evidências empiricas mostram que a contabilidade ainda fornece informaçōes relevantes, pelo menos dentro dos casos analisados nesses estudos.

\subsubsection{Conservadorismo}

O conservadorismo é uma das caracteristicas mais importantes do corpo de práticas e procedimentos da contabilidade. $O$ conservadorismo é presente nas estruturas contábeis do FASB, do IASC, do ASB (UK), dentro do modelo brasileiro

\footnotetext{
${ }^{30}$ Refere-se, no sentido adotado neste trabalho, à capacidade dos números contábeis de fornecer informaçoes
} 
e em todas as orientações contábeis que se tem notícia. Conservadorismo, em termos contábeis, normalmente tem sido caracterizado como o reconhecimento assimétrico entre despesas e passivos e ativos e receitas. $O$ pior cenário deve ser considerado de forma a escolher-se sempre pela opção com maiores despesas e passivos e menores ativos e receitas. A regra do custo ou mercado dos dois o menor para os estoques e o reconhecimento de perdas contingentes são os exemplos mais clássicos da aplicação do conservadorismo. No entanto, do ponto de vista econômico, conservadorismo significa somente reconhecimento viesado da realidade econômica. Projetos que possuem valor presente liquido positivo (Net Present Value) nāo sāo reconhecidos integralmente devido a regras de reconhecimento quando da realizaçāo da receita. A idéia geral do conservadorismo é de fornecer informações mais confiáveis aos investidores por intermédio de demonstrações que nāo sejam excessivamente otimistas.

No entanto, o exato montante do conservadorismo e o impacto do mesmo no conteúdo informativo da contabilidade sāo áreas que ainda carecem de estudo. O valor de livro (book value) abaixo do valor de mercado é um excelente indicador de conservadorismo na contabilidade uma vez que o mercado normalmente atribui valor a empresa mais rapidamente do que o patrimônio pode incorporar as boas noticias conforme demonstra BEAVER e RYAN, (1993) e PENMAN (1996). Por outro lado, o grau de conservadorismo da contabilidade em um dado pais, por exemplo, não depende somente da vontade intrinseca dos contadores e administradores de fornecer informações realistas sobre a empresa. Conforme demonstra BALL et all (2000), o grau de conservadorismo está diretamente ligado ao modelo de governança corporativo. Segundo esses autores, paises com modelos de common-law (Estados Unidos, Reino Unido, Canadá, Austrália, Nova Zelândia, etc.) e com contabilidade mais voltada ao investidor tendem a apresentar contabilidade mais conservadora do que paises inseridos em modelos de code-law (Japāo, Alemanha, etc.) e com contabilidade voltada ao atendimento 
do governo. Maiores detalhes são vistos na seção 3.4 especialmente voltada aos estudos da interface do modelo de governança corporativo de da contabilidade.

\subsubsection{Relevância do Patrimônio e do Patrimônio e Resultado}

A relação do patrimônio da empresa e o preço de mercado da mesma também tem sido estudada pelos pesquisadores em contabilidade. A diferença entre o valor de livro da empresa e o seu preço de mercado é conhecida como erro de mensuração (measurement error) e deveria ser igual a zero no longo prazo se não houvessem diferenças entre a mensuraçăo contábil e os preços de mercado. Devido às caracteristicas dos principios contábeis geralmente aceitos (GAAP, Generally Accepted Accounting Principles nos Estados Unidos e GAA Practices no Reino Unido) o valor do patrimônio da empresa nāo é igual ao valor de mercado da mesma. Dentro desse cenário o valor da empresa no mercado pode ser considerado como uma funçāo linear do valor de livro dos ativos e passivos da empresa. Formalmente:

$$
V M e=\Sigma V M A_{j}-\Sigma V M P_{k}
$$

Representado o valor de mercado da empresa como a diferença entre o valor de mercado de seus ativos e passivos. Pode-se afirmar também que o valor de livro do patrimônio da empresa é a diferença entre o valor de livro de seus ativos e passivos.

$$
B V e=\Sigma B V A_{j}-\Sigma B V P_{k}
$$

Em seguida pode-se expressar a diferença entre o valor de livro da empresa e o seu valor de mercado como:

$$
M V e-B V e=\left(\Sigma V M A_{j}-\Sigma B V A_{j}\right)-\left(\sum M V P_{k}-\sum B V P_{k}\right)
$$


Pode-se expressar o erro de mensuração nos ativos:

$$
B V A=\alpha_{j}+g_{j} V M A+e_{j}
$$

Estabelecendo o erro de mensuração para os passivos:

$$
B V P_{k}=\alpha_{k}+g_{k} V M P+e_{k}
$$

Estabelecendo uma possivel especificação para o valor da empresa em termos de seus valores de livro (book values) dos ativos e passivos.

$$
M V E=\alpha+\sum b_{j} B V A_{j}-\sum b_{k} B V L_{k}+u
$$

Essa última expressão apresenta uma estimação empirica muito utilizada na literatura contábil (BARTH, BEAVER and LADSMAN, 1993; BEAVER, EAGER, RYAN and WOLFSON, 1989; LANDSMAN, 1986; BARTH 1991). As evidèncias apresentadas por esses estudos demonstram que os dados de balanço são relevantes mas sāo menos relevantes do que os dados de resultado.

Após os trabalhos de FELTHAM-OHLSON (1995) and OHLSON (1995) muitos estudos começaram a ser realizados no sentido de explicar o comportamento dos preços em função de números de balanço. Os resultados empiricos desses estudos (BARTH, BEAVER and LANDSMAN, 1993; LANDSMAN, 1986; COLLINS et all 1997 mostram que as variáveis de balanço são importantes, mas que essa importância depende de vários fatores como o tipo de indústria, saúde financeira da empresa, etc. Normalmente considera-se que a relevância do patrimônio é maior em empresas com muitos ativos intangiveis e passando por dificuldades financeiras.

Vários estudos foram realizados para relacionar a relevância do lucro e de valores de balanço em uma série de condições especiais de mercado: (i) evidência 
empírica de inflação (DYCKMAN, 1975;DAVIDSON \& WEIL,1975; BEAVER e LANDSMAN, 1983 (ii) intangiveis (LEV and SOUGIANIS, 1996; AMIR and LEVI, 1996), (iii) itens especiais (ELLIOT and HANNA, 1996; BASU, 1997), (iv) prejuizos (HAYAN, 1995; BASU, 1997; BARTH et all, 1997; BURGSTAHKER and DICHEV, 1997, (v) tamanho das empresas (HAYAN, 1995). As conclusões gerais desses estudos são: (i) demonstraçōes ajustadas à inflação não fornecem informaçōes adicionais aos investidores; (ii) para empresas com grandes quantidades de ativos intangiveis lucros e valores de balanço não são relevantes, especialmente para empresas na indústria de celulares; (iii) o mercado dá menos valor a itens especiais em comparação com o resultado antes dos itens especiais - que corrobora a idéia de que os itens especiais não afetam a capacidade de geração de fluxos futuros de caixa da empresa; (iv) resultados negativos (prejuizos) impactam menos os preços do que resultados positivos; ( $v$ ) o valor do patrimônio possui maior importància do que o resultado em empresas pequenas para as quais a saúde financeira é menor e é observada menor persistência nos resultados.

Os resultados apresentados no item (v) acima possuem importância especial para este trabalho. $O$ mercado brasileiro possui caracteristicas bastante diferenciadas daquelas encontradas no mercado americano, onde a maior parte dos estudos citados acima foram realizados: (i) as empresas americanas são muito maiores do que as empresas brasileiras em sua maioria ${ }^{31}$; (ii) as condições de operaçāo no mercado brasileiro são muito mais instáveis e voláteis do que nos EUA (da COSTA, 1994); (iii) a contabilidade brasileira é amplamente regulamentada por intermédio de instrumentos legais, fator que, segundo BALL et all (2000) contribui para o empobrecimento da qualidade da informação contábil amplamente concebida; (iv) poucas empresas brasileiras tem seu controle negociado em bolsas de valores. Esses fatores contribuem para que a contabilidade perca relevância no contexto brasileiro. Esses aspectos serão

\footnotetext{
${ }^{31} \mathrm{Na}$ classificaçajo das 500 maiores cmpresas do mundo em 2000, segundo a revista Fortune, 197 cmpresas americanas foram classificadas em comparaçăo com somente 3 empresas brasileiras.
} 
abordados com maiores detalhes no item 3.4 que será a base para as hipóteses do trabalho apresentadas no capítulo 4.

\subsubsection{Precificação de Componentes Discricionários e Não- Discricionários}

Dentro da contabilidade existem várias possibilidades de escolha entre opçōes de tratamento contábil diferente para operaçōes semelhantes. Este comportamento discricionário pode ser motivado pela legislação tributária, regras de adequação de capital, "administraçāo" de resultados contábeis, etc. Existem fortes evidências de conteúdo informativo relacionado ao comportamento discricionário em provisōes para perdas com operaçōes passivas em instituiçōes financeiras (BEAVER, EAGER, RYAN e WOLFSON, 1989). Essa relevância do comportamento discricionário é vista como uma forma de comunicar informaçāo ao mercado advinda de administradores, contadores e outros com acesso a esse tipo de informação. GRIFFIN e WALLACH (1991) encontraram evidèncias que adiçōes inesperadas às provisões para devedores duvidosos de bancos sāo vistas favoravelmente pelo mercado. Em termos gerais, a evidència aponta para os componentes discricionários sendo avaliados positivamente pelo mercado enquanto os componentes obrigatórios sāo avaliados negativamente. Esses resultados sāo extremamente interessantes, uma vez que esses mecanismos discricionários sāo uma das principais formas de transmissão de informaçōes ao mercado. Naturalmente, essa área é uma fonte estudos e pesquisas muito fértil, uma vez que as caracteristicas discricionárias dos modelos contábeis mudam muito de pais para pais e variam ao longo do tempo dentro do mesmo arcabouço contábil.

No caso brasileiro, a provisão para devedores duvidosos é um bom exemplo. Apesar das exigências tributárias terem prevalecido em alguns momentos, as instituiçōes financeiras tem obrigatoriedade de apresentar provisōes superiores àquelas exigidas legalmente. O montante apresentado reflete a 
intenção da instituição de fornecer informaçōes ao mercado acerca da real situação de sua carteira de passivos. Obviamente, esse fluxo de informação dependerá do modelo de governança corporativo em questão. No Brasil, o modelo de governança, conforme será visto na seção correspondente, não induz as instituiçōes financeiras a fornecer informaçōes aos acionistas. No entanto, essa questão merece uma investigação própria.

\subsubsection{Volatilidade do Resultado e Risco Sistemático}

Seguindo a idéia de que os retornos esperados (e consequentemente os preços dos ativos) são funçōes do risco sistemático (beta), BEAVER, KETTLER e SCHOLES (1970), BEAVER e MAGNOLD (1975) e BEAVER, CLARKE e WRIGHT (1979) mostraram que medidas de volatilidade no resultado contábil sāo correlacionadas positivamente com o beta das açōes das empresas relacionadas. Esses resultados, praticamente inexplorados desde os trabalhos acima, tentam associar medidas de risco de mercado com medidas de risco nos resultados contábeis com o objetivo de verificar se a contabilidade ameniza o impacto das flutuaçōes reais na economia ou se esta reflete a volatilidade do mercado de forma integral. Espera-se que o resultado contábil seja menos volátil devido ao conservadorismo que causa reconhecimento assimétrico de resultados econòmicos nos números contábeis.

\subsubsection{Economia da Evidenciação}

Vários estudos têm tentando fornecer uma base formal mais adequada à contabilidade enquanto fenômeno econômico de forma a contribuir para o entendimento do papel da contabilidade no comportamento dos agentes econômicos e na formação de expectativas dos mesmos. Inicialmente, investigouse o papel da regulamentação no fornecimento de informaçōes contábeis. Très grandes linhas de investigação foram propostas para investigar possiveis lógicas para a regulamentação: (i) externalidades da informaçăo contábil, (ii) assimetria de 
informação entre investidores e administradores e (iii) incentivos fomecidos à administração da empresa para fornecer informaçōes. Os argumentos favorecendo a regulamentação da contabilidade sāo, em sua maior parte, baseados no argumento de que agèncias governamentais, e outros órgãos similares, possuem vantagens comparativas em relação ao mercado na exigência do fornecimento de informações. Esses argumentos baseiam-se na hipótese de que o mercado livremente não seria capaz de impor uma disciplina adequada para a evidenciação pública de informações; nesse cenário investidores minoritários e outros agentes menos favorecidos, como sindicatos, seriam penalizados. No entanto, não existem evidèncias empiricas claras a esse respeito. Casos como o do mercado financeiro e da contabilidade no Reino Unido, que permaneceram durante grande parte do século 20 totalmente absolutamente livre da influência governamental, sāo exemplos contrários à hipótese apresentada acima. No entanto, a investigação empírica desse assunto é bastante complicada devido ao grande número de fatores envolvidos na regulamentação de assuntos contábeis, como de muitos outros: (i) conseqüèncias na distribuiçăo de riqueza entre investidores e outros participantes do mercado, (ii) nivel de risco agregado associado com as várias opçōes, (iii) a contribuiçāo da contabilidade para o nivel geral de informaçāo do mercado, (iv) efeitos na taxa de acumulação de capital, (v) alocaçāo de recursos entre as firmas, (vi) uso de recursos na produçāo e disseminaçāo de informaçāo, (vii) atuaçāo do setor privado no processamento e disseminação de informações e, finalmente, (viii) os aspectos culturais inerentes ao processo de regulamentação. Estudos, dessa natureza, contribuem para o entendimento da contabilidade dentro de um contexto mais geral do que aquele especificamente relacionado ao impacto dos números contábeis no mercado financeiro. Nesse sentido, a contabilidade é vista fora do contexto da empresa impactando a sociedade de uma forma mais ampla.

Os estudos realizados na década de 70 (BEAVER, 1973; BEAVER e DEMSKI, 1974; BENSTON, 1969 e LEFTWICH, 1980) demonstram que não existem evidências claras de que a regulamentaçāo melhora a qualidade da 
informação contábil. Esses estudos demonstram que parte da assimetria informacional existente no mercado deve-se a opçōes racionais e intencionais dos agentes que consideram a relação custo vs. benefício da obtenção de informação. Outros pesquisadores, no entanto, argumentam que existem falhas no mercado no que se refere à produção de informação contábil na medida que o resultado não é PARETO eficiente (GONEDES e DOPUCH, 1974). Esse debate está centrado na classificação da informação contábil como bem público ou privado. A contabilidade é um bem público ou privado? Essa linha de pesquisa foi complementada pela economia da informaçāo. Assim, é assumido que os gestores, que possuem informações privilegiadas em relaçōes aos investidores, possuem incentivos para sinalizar informações (boas notícias, principalmente) ao mercado por intermédio da contabilidade. Esse fenômeno é acentuado se esses gestores acreditarem que a empresa está sub-avaliada pelo mercado. Nesse sentido, existe uma super produçāo de informaçāo. Esse fenômeno não possui benefício social. Essa linha de pesquisa também apresenta sérios questionamentos a respeito da capacidade de agências reguladoras fornecerem um modelo que seja eficiente economicamente. Não é claro que os custos de contratação privada sejam superiores aos incorridos no processo de regulamentaçāo.

Muito recentemente, alguns pesquisadores (LEUZ e VERRECHIA, 2000; BOTOSAN 1997; SENGUPTA, 1998) começaram a avaliar empiricamente a influència dos padrōes de evidenciaçāo nos atributos financeiros das empresas. A teoria básica da economia da informaçāo sugere que niveis maiores de informação reduzem o custo de capital das empresas, tanto em termos do nivel geral como aquele relacionado à assimetria de informação. Os resultados iniciais demonstram que existe uma forte e significante relaçāo entre a qualidade da informaçāo contábil e a redução do custo do capital. 


\subsection{Estudos a Respeito da Eficiência dos Mercados}

Os estudos apresentados nessa seção, apesar de fortemente relacionados com os analisados acima, distinguem-se devido ao enfoque voltado à verificação do nivel de eficiência do mercado em relaçāo à contabilidade e ao impacto destes niveis na produção de informaçōes. Apesar de alguma superposição de assuntos, essa seção justifica-se devidos ao objetivo do trabalho que está centrado na análise da contabilidade no mercado financeiro brasileiro. Assim, questōes acerca da contabilidade em sua interrelação com a eficiència dos mercados são relevantes. A próxima seção avalia detalhadamente a literatura que trata da contabilidade em mercados menos desenvolvidos.

\subsubsection{Previsibilidade dos Retornos}

A evidència geral nesse assunto é que a o comportamento das mudanças de preços sucessivas no mercado possui correlação aproximadamente igual a zero, com exceção de periodos extremamente curtos de tempo (COOTNER, 1964; FAMA, 1970, 1991). Conforme demonstrado por BEAVER e LANDSMAN (1981) procedimentos de seleçāo de açōes baseados em performance anormais passadas não produzem resultados que contrariem a hipótese dos mercados eficientes. Esses autores enfatizam nāo ser possivel a obtenção de retornos anormais com base em informações contábeis.

\subsubsection{Velocidade de Ajustamento do Preço ao Anúncio de Resultados}

Segundo a hipótese de eficiência na forma semi-forte os preços devem reagir imediatamente à publicação de informações contábeis. A evidência geral nesse sentido é que realmente os preços reagem rapidamente à contabilidade. Essa evidência é clara para dados semanais e diários (MORSE,1981), bem como para informaçōes coletadas em intervalos de horas (PATEL e WOLFSON, 1984). 


\subsubsection{Conteúdo Informativo dos Preços}

Desde os estudos pioneiros de BB, as evidèncias são claras de que os preços são capazes de antecipar os resultados das empresas. Para firmas com bons resultados contábeis, as variaçōes positivas cumulativas (acima do retomo ajustado ao risco) são positivas antes do mês de anúncio do resultado. Essa evidència decorre do fato de que os preços refletem uma base maior de informaçōes do que o resultado contábil.

\subsubsection{Avaliação de Notas Explicativas e Outras formas de Evidenciação}

Mercados eficientes são capazes de processar qualquer tipo de informaçăo, não importando o grau de complexidade da mesma. Outro aspecto importante desses mercados ideais, è que não importa como a informaçāo é apresentada (notas explicativas ou corpo do balanço). Assim, o mercado deveria ser capaz de interpretar a evidenciaçāo de assuntos complexos, como instrumentos financeiros e pensōes, da mesma forma que interpreta a evidenciação do método de avaliaçāo de estoques utilizado. Evidèncias nesse assunto sāo extremamente favoráveis à hipótese dos mercados eficientes. Pesquisas realizadas por LANDSMAN (1986), BARTH (1991) e BARTH, BEAVER e LANDSMAN (1992) demonstram claramente esse aspecto no que se refere aos beneficios de pensões. Da mesma forma, a evidenciaçāo de instrumentos financeiros também é rapidamente incorporada pelo mercado (BARTH, BEAVER e LANDSMAN, 1996 e VENKATACHALAN, 1997).

\subsubsection{Diferenças nos Métodos Contábeis e Preços}

Mudanças de práticas e métodos contábeis que nāo afetam o fluxo de caixa das empresas nāo devem impactar preços. Segundo essa visão, alguns autores testaram mudanças em métodos de avaliaçăo de estoques e de depreciação (ARCHIBALD, 1972; BALL, 1972 e BEAVER e DUKE, 1973). A evidencia desses 
estudos é contraditória e inconsistente.. Mudanças em métodos contábeis podem impactar preços em mercados eficientes sem que exista impacto no fluxo de caixa. Esse fenômeno deve-se à sinalização de informações ao mercado que tais mudanças podem representar. Muitos outros estudos foram realizados nessa arena sem apresentar, no entanto, evidências significativas. $O$ assunto possui grande importância na literatura contábil como comenta ARCHIBALD (1976:72):

"One treasurer flatly stated that an influential shareholder demanded the firm not show a relative profits decrease, and that the accountants were obliged to figure a way out of the problem. The depreciation change was the easiest and the most obvious."

Nesse sentido, FOSTER (1986: 159) resume as principais conclusōes da literatura no assunto:

"Accounting method choice is an important factor affecting reported financial statement numbers. The perspective taken ... is that the accounting method choice interacts with decisions concerning the mix of business, financing, and operating aspects of the firm. Increasing recognition is being given to the economic consequences to the firm and the economic consequences to management factors affecting accounting method choice. At the present, security analysts, financial comentators, and academics are better able to list factors such as taxation benefits, political costs, and executive compensation than to develop models that reliably predict how the foregoing (and possibly other) factors interact to produce the set of accounting methods chosen by individual firms. There is considerable evidence of selfselection by firms in their accounting method choices. Industry similarities and firm-size similarities have been documented. In addition, firms making voluntary accounting changes typically have experienced lower profitability and lower stock price performance in 
the period prior to the change. The existence of differences across firms in their accounting methods does not, in itself, preclude analysts from making interfirm comparisons of financial statement variables. The availability of suplemental information provided by firms and of aproximating techniques partially reduces potential problems arising from interfirm diversity in accounting method choice."

Assim, verifica-se que pesquisas adicionais são necessárias antes que o impacto das mudanças no métodos contábeis no mercado de capitais seja adequadamente modelado, principalmente em termos da visualização da sinalizaçāo de informaçōes por parte dos gestores. Outro aspecto, semelhante ao apresentado acima, que vem recebendo grande atenção dos pesquisadores recentemente refere-se ao impacto do formato, ou da demonstração na qual determinado item é apresentado no conjunto das informaçōes contábeis. Em um mercado razoavelmente eficiente, em termos informacionais, o formato, por exemplo, de uma determinada demonstração não deve impactar o entendimento dos investidores uma vez que nāo há diferença no conteúdo econômico informado. No entanto, as evidèncias a esse respeito sāo contraditórias com alguns autores advogando que alguns investidores, principalmente os não sofisticados, possuem reaçōes mais relacionadas com aspectos psicológicos do que a racionalidade econômica. Conforme comentam MAINES e MCDANIEL (2000:179)

"Statement of Financial Accounting Standards (SFAS) No. 130 requires companies to report comprehensive income in a primary financial statement, but allows its presentation in either a statement of comprehensive income or a statement of stockholders' equity. ..we examine whether and how alternative presentation formats affect nonprofessional investors' processing of comprehensive income information, specifically, informationdisclosing the volatility of unrealized gains on available-for-sale marketable securities. The 
results show that nonprofessional investors' judgments of corporate and management performance reflect the volatility of comprehensive only when it is presented in a statement of comprehensive income. We provide evidence that consistent with our psycholoy-based framework that these findings occur because format affects how nonprofessional investors weight comprehensive income information and not whether they acquire this information or how they evaluate it."

Resultados contrários foram encontrados por DAVIS-FRIDAY et all (1999). Esses autores investigaram a relevância do tratamento dado aos custos com passivos de beneficios a empregados. Dois tratamentos foram comparados: (i) evidenciação em notas explicativas e (ii) reconhecimento no balanço patrimonial. Os resultados apresentados indicam que o mercado reage mais prontamente às informaçōes simplesmente evidenciadas do que àquelas reconhecidas no corpo das demonstraçōes financeiras. Questōes acerca dos métodos contábeis sem impacto no fluxo de caixa das empresas e o dilema entre reconhecimento e evidenciação constituem-se em temas centrais e recorrentes na pesquisa em contabilidade. Alguns autores atribuem tal indefinição à ausência de um arcabouço conceitual claro e definido para a prática contábil como observa MACVE (1997):

"...while standard setters oftem argue that good disclosure is not a substitute for 'correct' accounting, and oftem appear to believe that moving towards greater use of current values will resolve many major difficulties of achieving good accounting, nevertheless one must equally understand that 'correct' accounting accounting can never be a substitute for good disclosure and for explanation of the accounitng principles adopted and assumptions made."

Assim, aparentemente essas questões continuarão presentes na literatura contábil. 


\subsubsection{Desvio Pós-Anúncio}

A presença de resultados anormais por longos periodos após anúncio de resultados (postannouncement drift) é uma evidência de anomalias em relação à hipótese geral de eficiència. FOSTER, OLSEN e SHELVIN (1984) documentaram retornos significantes após o anúncio de resultados com sinais negativos e positivos. Segundo esses autores a anomalia é maior para pequenas empresas. Trabalhos subsequentes e econometricamente mais adequados mostram as mesmas evidèncias (BERNARD e THOMAS, 1989, 1990). Esses resultados são inconsistentes com os apresentados acima $e$, devido à enorme atençāo dispensada ao entendimento dos resultados contábeis por analistas de mercado de capitais, surpreedentes. Alguns autores atribuem esses resultados a dependència serial entre os erros das previsōes dos analistas (ABARBANELL e BERNARD, 1992).

As anomalias sāo mais graves para ofertas públicas iniciais. Nesses casos, observa-se resultados anormais iniciais seguidos de resultados negativos no futuro. Segundo algumas pesquisas (DECHOW, SLOAN e SWEENEY, 1996) esse fato deve-se ao excessivo otimismo dos analistas. Esses resultados, apesar de ainda embrionários, são importantes porque alteram a crença geral de que analistas tomam o mercado mais eficiente por intermédio do processamento especializado de infromaçōes.

Os resultados gerais dessa literatura ${ }^{32}$ demonstram que, salvo raras anomalias, os mercados financeiros desenvolvidos (os estudos acima foram realizados predominantemente no mercado norte-americano e inglês) sāo eficientes em relaçāo à informaçāo contábil. $O$ estudo do desvio pós-anúncio pode ser relacionado com várias elementos com o intuito de determinar suas origens.

\footnotetext{
${ }^{32} \dot{E}$ importante ressaltar que, nos itens apresentados a revisio da literatura somente foca os estudos mais importantes. Uma descriçào completa dessa literatura é impossivel dentro dos limites deste trabalho.
} 
Recentemente BARTOV et all (2000:43) comentaram na relação do desvio com a sofisticação da base de investidores:

"Our findings show that the institutional holdings variable is negatively correlated with the observed post-announcement abnormal returns. Our findings also show that traditional proxies for transaction costs (i.e. trading volume, stock price) as well as firm size have little incremental power to explain post-announcement abnormal returns when institutional holding is an explanatory variable. If institutional ownership is a valid proxy for investor sophistication, these findings suggets that the trading activity of unsophisticated investors underlies the predictability of stock returns after earnings announcements. However, tests evaluating the validity of institutional holdings as a proxy for investor sophistication yield only mixed results."

Cabe ainda comentar a hipótese da fixaçāo funcional. Segundo tal hipótese, os investidores dāo atenção superior aos resultados de curto prazo (em termos de fluxo futuro de caixa) do que aos resultados futuros ajustados pela devida taxa de desconto. Essa atenção desproporcional ao curto prazo é normalmente atribuida a "miopia" dos investidores que dão exagerado valor aos resultados imediatos. Essa hipótese é relevante para a contabilidade que é uma das fontes de informação a respeito da qual os investidores podem apresentar tal comportamento.

\subsubsection{Lançamento de Opções e a Resposta do Preço aos Resultados}

O lançamento de opçōes sobre a ação de uma empresa possui grande impacto na eficiência informacional do mercado de suas açōes. A justificativa para tal fenômeno é que a existência de um mercado ativo de opçōes faz com que as expectativas do mercado possam ser visualizadas mais claramente. 0 comportamento do mercado de opçōes é fonte adicional de informaçōes acerca das açōes das empresas subjacentes. Apesar dessa relação entre mercado de 
opçōes e eficiência informacional das empresas subjacentes ser bem aceita na literatura, a direção de tal relação não é bem clara.

AMIN e LEE (1997:158) mostram que:

"A recurrent theme in previous studies is that option market availability appears to be associated with increased price effciency in the equity market. For firms with traded options, the stock price adjustment is faster, market price reactions to earnings news are smaller, and postannouncement drifts are less pronounced."

A justificativa conceitual para tais resultados é que a existência de um mercado ativo de opçōes contribui para o fluxo eficiente de informaçōes no mercado fazendo com que anomalias e demais desvios sejam mais raros. Por outro lado MENDENHALL e FEHRS (1999) estudando a resposta imediata dos preços aos anúncios de resultados contábeis sugerem que o impacto da existência de mercados de opçōes é diferente daquele apresentado na literatura. Conforme os autores comentam (MENDENHALL e FEHRS, 1999:58)

We provide evidence that suggests that the effect of option listing on the stock-price response to earnings announcements around the initiation of option trading...may be attributable to concurrent changes in firm size and to changing market-wide conditions. Specifically, we show that the previously documented reduction in the stock-price reaction to earnings around the time of option listing does not persist over a more recent time period. We aslo examine a matched-pair sample, for the 1973-1993 period, and find that the stock price response to earnings of matched firms, not experiencing option listing , falls by at least as much as those experiencing option listing. Further investigation reveals that the 1973-1986 period is characterized by a clustering of option-listing initiations that accurs (nearly) 
comtemporaneuosly with a large market-wide decline in the magnitude of stock-price reactions to earnings. Finally, we attempt to to combine the effects of changing firm size and changing market conditions. These results suggest that options listing may actually increase the immediate stock-price response to earnings announcements. Cross-sectional tests lend support to the longitudinal results mentioned above."

\begin{abstract}
A existência de resultados contraditórios como os evidenciados acima e outros como SKINNER, 1990; Ho 1993 e BOTOSAN e SKINNER, 1993, demonstram que essa linha de pesquisa precisa ser explorada com maior profundidade para conclusōes mais confiáveis possam ser levantadas.
\end{abstract}

\title{
3.2.8 Conclusöes Gerais da Literatura
}

Algumas observaçōes são necessárias para o esclarecimento dos resultados encontrados na literatura a respeito da eficiència dos mercados baseada no conjunto de informaçōes contábeis. O volume de pesquisa produzido nessa área é muito grande e novas evidèncias vèm sendo encontradas freqüentemente. A ligaçāo intrinseca entre a teoria e a realidade dos mercados financeiros faz com que essa linha de pesquisa goze de grande interesse entre acadèmicos, justificando, em parte, o volume de investigação realizado.

Percebe-se claramente pela definição de mercado eficiente apresentada no item 2.3 que o conceito de eficiência nos mercados somente pose ser discutido com base em um conjunto determinado de informaçōes. Eficiência de forma geral é um conceito de dificil verificaçāo empirica. A extensāo que um dado conjunto de informaçōes é avaliado, entendido e utilizado pelo mercado determina quão eficiente esse mercado é relativamente. No entanto, surge um paradoxo na medida que se os agentes económicos (analistas de mercado de capitais por exemplo) acreditarem que o mercado é eficiente, e que em consequência não 
existem oportunidades de lucros econômicos, esses não mais investirão recursos no processamento de informaçōes. O resultado dessa ação é que o mercado deixará de ser eficiente em relaçāo a esse determinado conjunto de informaçōes. O paradoxo nasce da necessidade que os agentes econômicos não acreditem que o mercado é eficiente (e dessa forma, processem informações buscando lucros econômicos) para que esse mercado possa tormar-se eficiente. LORIE e HAMILTON (1973: 98) comentam:

"There is a curious paradox. In order for the efficient markets hypothesis to be true, it is necessary for many investors to disbelieve it. That is, market prices will promptly and fully reflect what is kowable about the companies whose shares are traded only if investors seek to earn superior returns, make conscientious and competent efforts to learn about the companies whose securities are traded, and analyse relevant information promptly and perceptively. If that effort were abandoned, the efficiency of the market would diminush rapidly."

Esse paradoxo foi resolvido por GROSSMAN e STIGLER (1980) no artigo "On the Impossibility of Informationally Efficient Markets". A linha de argumentação dos autores é de que os agentes nảo utilizam toda a informação disponivel no mercado devido ao custo de processamento desta. Assim, parte da informaçāo disponivel nunca será utilizada e os preços não refletirāo tal parcela. Dessa forma, o preço de mercado não será o preço que reflete toda a informação disponivel. $O$ preço ideal do ponto de vista informacional não será o preço de mercado. BULKIEL (2000) apresenta essas idéias graficamente da seguinte forma: 
FIGURA 4

Preço de Mercado e Preço Informacionalmente Ideal

'reço

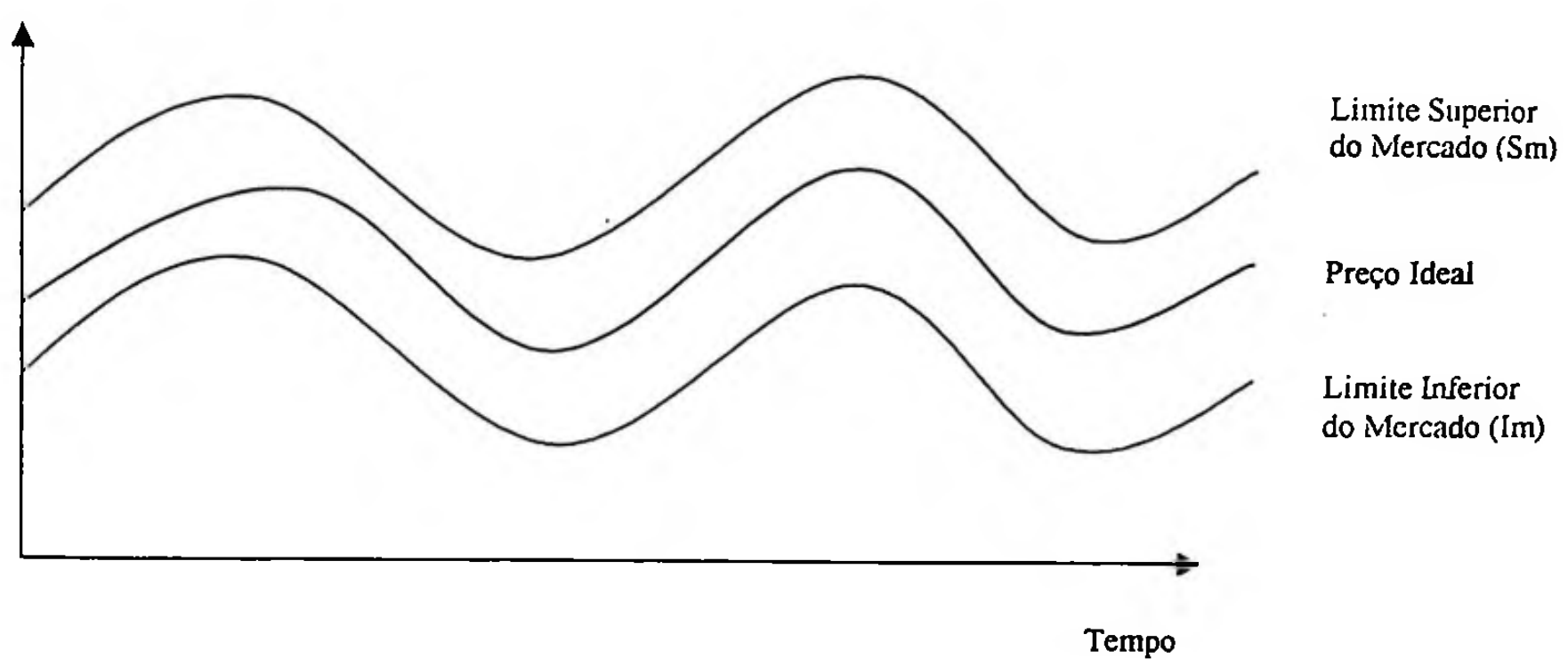

Segundo essa abordagem o preço de mercado ficará na faixa entre Sm e Im refletindo algo conhecido informational noise (ruido informacional). Essa faixa será maior ou menor dependendo do grau de processamento do conjunto de informaçōes analisados, o que por sua vez depende do grau de desenvolvimento do mercado. Assim, o conjunto de informações contábil pode estar refletido em maior ou menor grau nos preços de mercado, mas nunca completamente. No entanto, as características específicas da informação refletida bem como o nivel informacional dos preços de mercado são pontos de questionamento contínuo.

\subsection{Informação Contábil em Mercados não desenvolvidos}

Conforme visto acima, a literatura acerca da relação entre a contabilidade e - mercado financeiro é bastante rica. No entanto, essa literatura centra-se, principalmente, em evidências empíricas advindas dos mercados americanos e inglês. Esses dois mercados possuem modelos de governança similares (de forma geral) onde a contabilidade é pouco regulamentada e voltada, principalmente, para investidores de mercado de capitais (BALL et all, 2000). Dessa forma, os 
resultados acima não são surpreendentes na medida que a contabilidade nestes dois paises tem o investidor de mercados de capitais como usuário priomordial. No entanto, pesquisas realizadas em mercados emergentes ou menos desenvolvidos são quase que inexistentes; especialmente tratando-se de América Latina. Algumas razōes para esse desinteresse acadêmico normalmente apresentadas são:

- a aplicação da teoria econômica é a mesma em qualquer lugar. Nesse sentido não existem questōes novas a serem avaliadas nos mercados emergentes;

- esses mercados estão em estágios de embrionários de desenvolvimento. No futuro apresentarão características similares aos mercados mais desenvolvidos. Nesse sentido, tais mercados somente apresentam interesse histórico aos pesquisadores;

- devido a idiossincrasias, a análise de tais mercados nāo pode ser generalizada.

Esses argumentos, naturalmente, não justificam a ausência de literatura e evidencias do papel da contabilidade para tais mercados. Tais argumentos podem ser facilmente refutados como apresenta ANG (1991):

- a inclusāo de novos dados pode mudar radicalmente a visāo existente dos problemas econômicos tradicionais relacionados à instituiçōes e mercados, investimentos e finanças corporativas;

- instituiçōes financeiras, mercados, instrumentos financeiros e práticas contábeis não são necessariamente menos desenvolvidas nesses paises. Muitos desenvolvimentos, como o método da correção monetária integral no Brasil, são gerados em mercados considerados 
menos desenvolvidos. As demandas criadas por mercados instáveis e menos organizados podem gerar soluçōes extremamente interessantes. A simples sobrevivência de tais mercados já é motivo para investigaçăo detalhada;

- tais mercados podem ser utilizados como laboratórios para testes de novas teorias que envolvem condiçōes extremas de mercado. Alguns mecanismos de mercados, produtos e condiçōes de atuação, sāo simplesmente nāo existentes em mercados mais desenvolvidos. Um bom exemplo desse tipo de evidência é fornecido por LEUZ e VERRECHIA (2000) que analisam a redução da parte devida à assimetria de informação do custo de capital para empresas alemās após a adoção de padrōes de contabilidade internacional (International Accounting Standards, IAS). Esse tipo de estudo nāo é possivel no mercado americano que já é bastante rico em termos informacionais.

O estágio atual da pesquisa contábil está muito distante de responder todas as questōes acerca do impacto da informaçāo sobre os agentes econômicos. Conforme pode ser visto na revisāo da literatura apresentada acima, muitas questōes importantes ainda aguardam investigaçāo. Nesse cenário, novas evidências podem contribuir em muito para o entendimento do papel da contabilidade no mercado financeiro e na sociedade de forma geral. Evidências advindas de mercados emergentes podem, inclusive, contribuir para o entendimento de eventos ocorridos nos mercados mais desenvolvidos.

No entanto, apesar desses argumentos, as pesquisas em mercados emergentes tem sido realizadas com pouco ou nenhum entusiasmo. Como apresentado por CHOI e LEVICH (1990):

"While considerable attention has been given in academic and professional activities to the identification of diverse accounting 
principles in various countries, little work has been devoted to the important question of whether such differences actually have an impact on international market activity."

Como esses mesmos autores comentam, muitas questōes importantes em contabilidade financeira ficam sem resposta devido à ausência de tratamento econômico formalizado e de evidências empíricas. Será realmente que a harmonização de práticas contábeis possui beneficios diretos para os investidores em mercado de capitais? Seria interessante se órgãos de regulamentação e policy makers da área contábil pudessem contar com evidências mais claras a esse respeito para orientar os caminhos da profissāo; por enquanto essas questões ainda são avaliadas por intermédio de experiência profissional e julgamento simples, sem maior base teórica. Como CHOI e LEVICH (1990) apontam:

"In our view, progress toward harmonised standards may continue to be slow and the benefits of any new policy uncertain in the absence of empinical evidence as to whether, and in what specific ways, accounting diversity affects capital markets decisions."

Dessa forma, essa seçāo analisa a pesquisa em contabilidade em "mercados menos desenvolvidos" número recente de evidências nas Bolsas de Valores Chinesas (Hong Kong e Pequim). BAO e CHOW (1999) mostram que resultados contábeis baseados nos padrōes de contabilidade internacionais (IAS ou International Accounting Statements emitidos pelo International Accounting Standards Committee-IASC que recentemente emitiu o corpo completo de normais internacionais) possuem

\footnotetext{
${ }^{33}$ Como pode ser observado ao longo do texto, não existe a prcocupaçăo em fornecer uma definiçăo formal do que sejam mercados mais ou menos desenvolvidos $\mathrm{cm}$ termos de contabilidade financcira. Para as finalidades deste estudo, mercados menos desenvolvidos, em termos de contabilidade financcira, são todos os países com cxceção dos Estados Unidos $\mathrm{e}$ da Inglaterra. Essa divisảo năo tem o objetivo de classificar os mercados, mas somente de separar os dois paises supracitados, que possuem grande montante de evidências na literatura a respeito do impacto da contabilidade no funcionamento dos seus respectivos mercados, do restante dos paises que recebcram menos atenção da literatura. A análise das cvidèncias no Japảo, Canadá e
} 
conteúdo informativo superior do que àqueles baseados nos padrões contábeis chineses com sinais de que a relevância dos números reportados segundo os padrōes internacionais aumenta com o passar do tempo. No entanto, os números reportados segundo a contabilidade chinesa possuem poder explicativo relevante ( $21 \%$ em média). Esse estudo documenta que o valor do patrimônio baseado nos padrōes internacionais possui poder explicativo irrelevante; esse aspecto, segundo hipótese do autor, deve-se aos altos niveis de inflação na China. O trabalho usa as açōes tipo $\mathrm{B}^{34}$ como base para a avaliaçāo das empresas.

CHAN e SEOW (1996) mostraram resultados muito interessantes ao comparar a relevância de demonstraçōes preparadas de acordo com a contabilidade praticada na China com àquelas ajustadas para os US-GAAP (Generally Accepted Accounting Principles ou principios contábeis geralmente aceitos nos Estados Unidos) para as empresas listadas na Bolsa de Valores de Nova York (NYSE, New York Stock Exchange). Os resultados demonstram que as demonstraçōes domésticas sāo mais relevantes do que àquelas adaptadas ao modelo americano. Podem ser apontadas várias razōes para esse fenômeno: (i) fatores culturais que nāo são captados pela "conversāo" ao modelo americano, (ii) qualidade superior da contabilidade chinesa (porque não?), etc. No entanto, independentemente das razōes para esse fenômeno, tal evidência coloca em cheque as custosas exigências que a SEC impöe às empresas estrangeiras para que possam ter suas açōes negociadas nas bolsas americanas. A premissa básica de que os padrōes contábeis americanos sāo "superiores" em termos de conteúdo informativo para os investidores de mercado de capitais parece não ser tāo verdadeira. Esse é um exemplo de como estudos empíricos em contabilidade financeira internacional podem contribuir para o debate sobre regulamentaçāo contábil. Nesse caso especifico, mostrou-se que o argumento da SEC para as

Alemanha (por exemplo) reflete essa visło e nảo a idéia de que tais paises possuem mercados de capitais em desenvolvimento.

${ }^{34}$ Açð̋es tipo B são emitidas por empresas chinesas para investidores estrangeiros e săo iguais em termos de direitos e obrigaçð̃es às ações tipo A emitidas para os cidadãos chineses. 
enormes exigências impostas às empresas estrangeiras possui caráter mais político do que técnico.

Ainda na contabilidade chinesa, CHEN, GUL e SU (1999) fornecem uma discussāo detalhada das diferenças entre a contabilidade praticada na China e os padrōes contábeis americanos. LIN e FENG (2000) e HAGIGI, TAN e WU (2000) fornecem evidências complementares sobre as práticas contábeis praticadas naquele pais. Para empresas negociadas em Hong Kong, CHUNG e KIM (1997) examinaram a utilidade relativa incremental de índices valor de livro/ preço (bookto-price ratios) e resultado/ preço (Earnings/Price) no fornecimento de informaçōes para formaçāo de estratégias lucrativas para previsāo de resultados. A evidência dos autores demonstra que é possivel a realização de lucros acima da remuneraçāo pelo risco devido a ineficiências presentes no mercado.

Na Europa, O'CONNEL (1995) examinou o conteúdo informativo dos preços na Irish Stock Exchange de forma agregada em subgrupos ligados ao tamanho da empresa e classificação de atividades. $O$ autor encontrou evidências que 0 conteúdo informativo dos preços nāo é significativo em termos das demonstrações contábeis subsequentes. Devido às caracteristicas do mercado analisado o autor nāo apresenta explicaçōes para o fenômeno e sugere que pesquisas futuras sejam realizadas.

Para empresas alemãs que migraram dos padrōes contábeis locais para os internacionais (IAS), houve grande redução na parte relativa à assimetria de informação do custo de capital segundo LEUZ e VERRECHIA (2000) conforme apresentado anteriormente. Estes resultados demonstram que mesmo no mercado alemāo, considerado como desenvolvido por alguns autores (SHAPIRO, 1998), pode haver aumento no nivel geral de informaçōes por intermédio da adoção de padrōes contábeis diferenciados. Esse trabalho, obviamente, levanta a mesma questāo para os mercados emergentes. O adoção dos IAS no Brasil, produziria resultados semelhantes? 
BOOTH, KALLUNKI e MARTIKAINEN (1996) encontraram evidências de efeitos de suavizaçāo de resultado (smoothing effect on earnings) e grande desvio pós anúncio (post-announcement drift) para empresas finlandesas. Segundo os autores, parte desse fenômeno pode ser explicado pelo alto custo de processamento de informaçōes e negociaçāo ligado às pequenas empresas no mercado finlandès. Resultados semelhantes foram encontrados para empresas suecas (FORSGARDH e HERTZEM, 1975).

Na Espanha, BALLESTER e LIVNAT (1997) encontraram evidèncias que os resultados contábeis tornaram-se relevantes com grande associação com os preços de mercado após a transição de um modelo contábil voltada para aspectos tributários para um modelo mais voltado às demandas dos investidores durante os anos 90 .

Para empresas Australianas, o estudo de BALL e BROWN (1968) foi repetido com resultados similares por BROWN (1970). No caso australiano, o movimento de preços antes do anúncio de resultados contábeis é mais errático do que no exemplo americano. Essa diferença reflete o fato de que as empresas australianas produzem demonstrativos semestralmente e nāo trimestralmente como as americanas. Para as empresas da Nova Zelândia, o trabalho de HOSSAIN, PERERA e RAHMAN (1995) fornece evidèncias descritivas importantes acerca do desenvolvimento da contabilidade local.

ENG, KHOO e TAN (1998) apresentaram resultados consistentes com a hipótese de que o patrimônio contábil das empresas é altamente correlacionado com os preços em Singapura. Para ofertas públicas inicias (IPO ou Initial Public Offering), segundo os autores, a escolha dos auditores e outros aspectos operacionais não são relevantes, o que contraria o esperado segundo a literatura do assunto. DIGA e SAUDAGARAM (2000) e HUTAGOL, HARRISON e MCKINNON (2000) descrevem em detalhes a estrutura do mercado financeiro 
Indonésio e a interaçāo do mesmo com a contabilidade financeira no país sem, no entanto, fornecer evidèncias empiricas conclusivas. Para o mercado turco existem evidências descritivas fornecidas por ÇURUK and COOKE (2000). Evidências adicionais sāo fornecidas para a República Tcheca (JELIC, ALEXANDER and BRISTON, 2000), Bahrain (AL-BASTEKI, 2000), Arábia Saudita (AL-RUMAIHI, POWER and SINCLAIR, 2000) Jordāo (ABU-NASSAR and RUTHERFORD, 2000) e Zimbabwe (OWUSU-ANSAH, 2000).

Tentando correlacionar variáveis macroeconômicas e contabilidade internacional, LARSON e YORK (1995) examinaram a relaçāo entre a adoção dos padrōes de contabilidade internacional, desenvolvimento do mercado de capitais e crescimento econômico em paises em desenvolvimento. Os resultados encontrados indicam que năo existem relaçăo entre as variáveis estudadas e a adoçāo de padrōes de contabilidade internacional. Por outro lado, GUENTHER e YOUNG (2000) estudaram a relaçāo entre os resultados contábeis em diversos paises e variáveis macroeconômicas relacionadas com o nivel geral de atividade. Baseado na premissa que devido à influência das demandas fiscais na contabilidade financeira, estruturas legais, demanda pela informaçāo contábil, proteçāo aos investidores minoritários, os resultados contábeis nos Estados Unidos e no Reino Unido possuiriam maior relaçāo com as variáveis macroeconômicas analisadas. Os resultados demonstram conformidade com a hipótese apresentada. NARAYANASWAMY (1996) descreveram o impacto que a liberalização econômica na İndia causou na contabilidade financeira. $O$ trabalho utiliza um estudo de caso para indicar os incentivos para a evidenciação de informaçōes em conformidade com os principios internacionais de contabilidade.

Comparando o conteúdo informativo e a oportunidade (timeliness) do resultado contábil em 17 paises utilizado os Estados Unidos como benchmark, ALFORD, LEFTWICH e ZMIJEISKI (1993) encontraram diferenças significativas na amostra analisada. Segundo os autores, os resultados contábeis encontrados na França, Austrália, Reino Unido e Holanda sāo mais relevantes e oportunos do 
que os americanos. Para a Bélgica, Canadá, Hong Kong, Irlanda, Japāo, Noruega, África do Sul e Suiça os resultados são inconclusivos quando comparados com o padrão. Para a Dinamarca, Alemanhā, Itália, Singapura e Suécia, os números contábeis fornecem informaçōes claramente inferiores quando comparados com os Estados Unidos. Apesar do recente aumento modesto nos trabalhos nessa literatura para mercados desenvolvidos (FORSGARDH e HERTZEN, 1975; GRAY, 1980; MEEK, 1983, 1985, 1991; MAINGOT, 1984; SAKAKIBARA, YMAJI, SAKURAI, SHIROSHITA E FUKUDA, 1988; WEETMAN E GRAY, 1990; DARROUGH e HARRIS, 1991; LEE E LIVINAT, 1991; STRONG e WALKER, 1991; CHU e RONEN, 1992; POPE e INYANGETE, 1992; POPE e REES, 1993, SMITH e TREMAYNE, 1992) muitas inconsistèncias e resultados contraditórios ainda podem ser encontrados. HARRIS, LANG e MÖLLER (1994), por exemplo, apresentam evidências de informaçōes fornecidas na Alemanha com conteúdo informativo superior àquelas produzidas nos Estados Unidos. Esses resultados contraditórios impedem a formaçāo de uma teoria mais ampla para a contabilidade financeira internacional, quando se relaciona o impacto de fatores locais e econômicos na contabilidade financeira.

Utilizando uma base teórica mais ampla e realizando um trabalho mais analitico, BARTH, CLINCH e SHIBANO (1999) demonstram que a harmonizaçāo de práticas contábeis não è um objetivo necessariamente desejável. Esses autores chegaram a essa conclusão por intermédio da comparação da "imprecisão informacional" relacionada com a harmonizaçăo (emergência de um conjunto de informações que será processado de forma inconsistente por investidores diferentes) com os custos associados com o aprendizado dos padrōes contábeis nacionais por investidores estrangeiros. Os resultados indicam que os custos de treinamento de investidores estrangeiros são relativamente pequenos quando comparados com a perda de informação advinda da harmonizaçāo. Tais resultados nāo sāo direcionados aos mercados emergentes, mas os resultados podem ser facilmente generalizados. Ainda tentando modelar o comportamento dos investidores frente a diversos modelos contábeis, HUDHART, HUGHES e 
BRUNNERMEIER (1999) fornecem evidências de que as exigências de evidenciação sāo concentradas em algumas bolsas sugerindo que tais instituições obtêm beneficios por intermédio de tais exigências. Esses resultados impactam diretamente as bolsas de valores e mercadorias em paises emergentes que competem por liquidez no cenário internacional.

As evidências a respeito da América Latina na literatura contábil internacional são praticamente nāo existentes. Normalmente, menções à realidade latino-americana sāo feitas em caráter superficial sem maiores evidências empíricas (KHALAF, 1993). Alguns estudos como DOPUPNIK, MARTINS e BARBIERI (1995) são primordialmente descritivos. Muito recentemente DAVISFRIDAY e RIVERA (2000) examinaram o conteúdo informativo da contabilidade mexicana em comparação com os padrōes contábeis americanos (US-GAAP) para empresas listadas em ambos os paises. Os resultados indicam que a contabilidade mexicana produz demonstraçōes mais relevantes do aquelas ajustadas aos padrōes americanos. Esse resultado è uma evidência a mais na demonstraçāo de que as exigências elevadas da SEC para empresas estrangeiras não possui embasamento técnico. KANITZ (1973) ${ }^{35}$ propōe um modelo de previsāo de insolvência para empresas brasileiras baseado fundamentalmente em informações contábeis. Tal trabalho, no entanto, nāo correlaciona os resultados obtidos com empresas negociadas em bolsas de valores e não apresenta implicações mais detalhadas para a "qualidade" da informação emanada pela contabilidade.

Fora dos temas contábeis propriamente ditos, a literatura de finanças empiricas apresenta grande volume de evidências acerca do comportamento dos mercados emergentes (incluindo o Brasil) em termos de fluxo de informações e eficiencia relativa. Do ponto de vista descritivo, BAER e MILES (2000) fomecem uma descrição precisa da estrutura do mercado financeiro brasileiro focada no papel das instituiçōes financeiras. A análise da eficiência do mercado brasileiro foi 
realizada especificamente por RATNER e LEAL (1999) que mostraram não haver evidências de que técnicas de alocaçāo de recursos baseadas em informaçōes passadas (especificamente neste estudo a técnica média móvel ajustada- VMA ou variable lenght moving average) produzem resultados acima da remuneração pelo risco dos titulos. Na mesma linha, da COSTA (1994) investiga a questāo da "reaçāo exagerada" dos preços no mercado brasileiro. Os resultados indicam que a magnitude da reversāo dos preços (price reversals) é mais pronunciada do que no caso norte-americano. No entanto, as evidências são claras da existência do efeito. KARAFIATH, MYNATT e SMITH (1991) documentam evidências a respeito do efeito contágio no anúncio da moratória de 20 de Fevereiro de 1997 demonstrando claros sinais do mesmo.

Assim, pode-se ver que alguns estudos foram realizados no mercado financeiro brasileiro fornecendo evidências descritivas do comportamento do mesmo em termos de funcionamento, contratos e risco sistêmico. A seção 3.5 fornece mais detalhes das evidências existentes sobre o mercado brasileiro.

A literatura nacional também vem apresentado poucas contribuiçōes ao estudo empírico do papel da contabilidade no mercado brasileiro. CARVALHO (1999) fornece evidências de que o comportamento dos preços das açōes negociadas na Bolsa de Valores de São Paulo (BOVESPA) possui baixa correlação com a variaçāo do EVA ${ }^{\oplus}$ (Economic Value Added ou valor económico agregado). No entanto, esse trabalho nāo apresenta o teste de um modelo analitico determinado, utilizando a correlação simples de forma ad hoc. Assim, verifica-se a relativa ausència de documentaçāo nesse assunto no Brasil.

De uma forma geral, pode-se observar que a contabilidade em mercados emergentes ou menos desenvolvidos vem recebendo pouca ou nenhuma atenção da academia contábil internacional. O Brasil coloca-se como caso a parte nesse cenário com evidências escassas acerca do papel da contabilidade no mercado

${ }^{35}$ Segundo o conhecimento do autor esse é o trabalho pioneiro em termos de pesquisas empiricas utilizando 
nacional. Essa lacuna na literatura empobrece o entendimento da realidade económica nacional. Pesquisadores, estudantes e executivos contábeis e financeiros seriam beneficiados por análises mais detalhadas do mercado nacional.

\subsection{Informação Contábil e Governança Corporativa}

Neste trabalho, a definiçāo de governança corporativa empregada é a de SHLEIFER e VISHNY (1997: 737):

"Corporate governance deals with the ways in which suppliers of finance to corporations assure themselves of getting return on their investment."

Essa linha de pesquisa relativamente recente em finanças procura analisar a relaçāo entre os fornecedores de capital e os administradores das empresas. Essa relação envolve uma série de fatores legais, económicos e culturais que criam o ambiente propicio para que determinados tipos de relações estabeleçam-se. 0 tema de governança corporativa ganha importância maior na literatura econômica na medida que diferenças entre os modelos de governança associam-se com desenvolvimento económico e do mercado de capitais. Como comentam SHLEIFER e VISHNY (1997: 737-738):

“...the United States, Germany, Japan and the United Kingdom have some of the best corporate governance systems in the world, and the differences between them are probably small relative to their differences from other countries...Italian corporate governance mechanisms are so undeveloped as to substantially retard the flow of external capital to the firms. In less developed countries, including some of the transition economies, corporate governance mechanisms 
are practically nonexistent. In Russia the weakness of corporate governance mechanisms leads to substantial diversion of assets by managers of many privatized firms, and the virtual nonexistence of external capital supply to firms. Understanding corporate governance not only enlightens the discussion of perhaps marginal improvements in rich economies, but also can stimulate major institutional changes in places where they need to be made."

Os estudos de governança sāo um rompimento com a teoria clássica que preconizava que somente a competiçăo das firmas no mercado seria suficiente para resolver os problemas de governança (ALCHIAN, 1950 e STIGLER, 1958). Segundo essa forma evolucionária de ver a teoria econômica estudos de governança sāo desnecessários. No entanto, as evidências empiricas sāo claras no sentido de que os problemas de governança corporativa são importantes e não sāo resolvidos naturalmente pelo mercado. Vários mecanismos de governança são importantes e têm sido estudados na literatura. Os resultados encontrados até o momento sāo claramente favoráveis a hipótese de que a governança corporativa possui papel central na moderna teoria de finanças.

Neste trabalho somente serão apresentados aqueles relacionados com a contabilidade, como será visto a seguir. Outro aspecto caracteristico dessa revisāo, e do restante do trabalho, é utilização do paradigma econômico clássico. Existem outros tratamentos heterodoxos para o assunto que não sāo apresentados nessa revisão. Assim, esta seção nāo fornece uma revisāo exaustiva da literatura em governança corporativa.

Desde os primeiros estudos modernos em governança, o papel da contabilidade tem sido reconhecido. Vários funçöes tem sido verificadas, desde instrumento fundamental para o estabelecimento de contratos entre os agentes até o papel de redutora da assimetria de informação. Na realização de contratos entre os principais e os agentes SHLEIFER e VISHNY (1997: 745) mostram que: 
The more serious problem with high powered contracts is that they create enormous opportunities for self-dealing for the managers, especially if these contracts are negotiated with poorly motivated board of directors rather than with large investors. Managers may negotiate for themselves such contracts when they know that earnings and stock prices are likely to rise, or even manipulate accounting numbers and investment policy to increase their pay."

Citações como essa são comuns na literatura de governança. No entanto, trabalhos especificos relativos ao papel da contabilidade nos modelos de governança não haviam sido realizados até muito pouco tempo atrás. Muito recentemente, a literatura contábil tem procurado ampliar as fronteiras do entendimento do papel da contabilidade nos mercados financeiros. A governança corporativa tem sido apresentada como um importante fator sendo influenciado e influenciando a contabilidade. Dois modelos gerais legais sāo de grande importancia para a contabilidade: common law e code law. Os paises que adotam - sistema de common law (direito consuetudinário) possuem instituiçōes e modelos de regulamentaçāo completamente diferentes daqueles que adotam sistemas de code law (ou direito romano). Para a contabilidade as seguintes diferenças parecem ser importantes (BALL et all, 2000):

- regulamentação: os paises que adotam o modelo de common law possuem estruturas gerais de organização menos regulamentadas do que os seus correspondentes adeptos do direito romano. Essa determinaçăo pode ser notada no mercado financeiro, na estrutura da profissāo contábil, auditoria, etc. O Reino Unido é apresentado como caso extremo de common law system. Até recentemente, o mercado financeiro inglès e a contabilidade eram totalmente auto-regulamentados. É importante notar que o papel da regulamentação nos modelos legais citados varia muito entre paises. Muitos paises tiveram sistemas legais iniciais muito próximos 
do sistema consuetudinário e vem migrando gradativamente para sistemas baseados na legislação escrita (Estados Unidos). Cabe ressaltar que esses sistemas podem coexistir dentro de um mesmo país na regulamentação de assuntos distintos;

- estrutura Acionária: normalmente, paises que adotam o modelo de common law possuem mercado de capitais bem desenvolvidos com estrutura acionária dispersa entre um grande número de acionistas (shareholder system). Acionistas individuais raramente possuem controle sobre as empresas e o este está dissociado da administração. Estados Unidos, Reino Unido, Austrália e Canadá são exemplos claros desse sistema. Nos paises que adotam o modelo de code law, normalmente o modelo de stakeholder predomina. Nesses casos o controle das empresas está concentrado nas mãos de poucos acionistas que normalmente estão ligados diretamente a gestão das empresas ou possuem outros tipos de relaçōes diretas como credores ou empregados. Alemanha e Japão são exemplos desse modelo onde os financiadores das empresas possuem grandes participaçōes nestas sendo o controle público praticamente inexistente. $O$ impacto desses dois sistemas no papel da contabilidade é enorme. No modelo shareholder os acionistas estāo dispersos e demandam informaçōes permanentemente para reduzir a assimetria informacional em relação aos administradores que possuem informações privilegiadas. A contabilidade nesses casos possui a função de levar informaçōes e sinais ao mercado devendo possuir certas caracteristicas para atender a tais demandas. No modelo stakeholder os acionistas estão dentro das empresas (como os credores nas empresas alemãs). Assim, a contabilidade não possui o papel de reduzir assimetria de informação, uma vez que essa não existe da mesma forma que no grupo anterior;

- força da profissão contábil: parece haver uma relação direta entre o prestígio e a relevância da profissão contábil e a estrutura legal dos paises. 
Paises que possuem o modelo common law possuem profissões contábeis auto regulamentadas com enorme impacto social e prestígio (BALL et all, 2000). Nesses paises é mais provável que a profissão venha a influenciar o conteúdo dos pronunciamentos e eventuais regulamentações contábeis que estão, normalmente, na esfera governamental no caso dos paises de direito romano. Essa influência da profissão nos padröes e práticas contábeis parece contribuir para o aumento da qualidade da contabilidade praticada nesses paises;

- impacto tributário na contabilidade: um aspecto que diferencia claramente os dois grupos de paises apresentadas acima é o grau de influência da legislação tributária na contabilidade. A influência da legislação tributária na contabilidade é muito pequena em paises como o Reino Unido onde a contabilidade e a tributação são tratados como assuntos diferentes, possuindo certificaçōes profissionais próprias inclusive. Em paises como a Alemanha a contabilidade confunde-se com o código tributário. A contabilidade não possui corpo teórico próprio e estruturas conceituais básicas são inexistentes;

- obrigatoriedade do pagamento de dividendos: Segundo La PORTA et all (2000) a obrigatoriedade, ou não, do pagamento de dividendos impacta diretamente a "qualidade" do lucro contábil em paises nos quais os dividendos estão legalmente associados ao lucro. Segundo os autores uma estrutura de dividendos obrigatórios leva os administradores a tentar manipular o lucro para que esse possa se adequar à politica de dividendos. Os autores justificam a exclusão dos paises com pagamento obrigatório de dividendos de suas pesquisas, assim (La PORTA et all, 2000: 9-10):

"We note in particular the exclusion of countries with mandatory dividend rules, namely Brazil, Chile, Colombia, Greece and Venezuela. Some of these countries have weak legal protection of 
minority shareholders. The fact that, in such environments, regulators choose to force companies to pay dividends is in itself some evidence in favor of the importance of agency considerations, since the most plausible reason for a mandatory dividend policy is to assure outside investors that they would not be expropriated entirely, and thus to encourage participation in the equity markets by such investors. In general, firms in mandatory dividend countries have higher payouts than firms in countries without such rules, but they nevertheless appear, in the data, to have lower payouts than required by the law. $A$ possible reason for this is that accounting earnings reported to the authorities for the purposes of compliance with mandatory dividend rules are lower than the earnings reported to the shareholders which we use in our analysis."

Essas observaçōes, apesar de confeccionadas em outro contexto, mostram a preocupação com o impacto da obrigatoriedade do pagamento de dividendos nos resultados contábeis publicados.

- regulamentação contábil: nos paises que adotam o modelo de common law a contabilidade está fora da esfera de influência governamental. Nesses paises mesmo quando órgāos governamentais possuem a autoridade para regulamentar a profissāo e as práticas contábeis estes transferem tal autoridade para órgāos privados que acomodam membros da profissāo e do mercado em seus quadros decisórios (exemplo típico da autonomia da SEC de regular a contabilidade americana que foi transferida para o FASB). Em estruturas legais mais voltadas ao modelo de code law a contabilidade é normalmente regulada legalmente diretamente pelo governo central (Ministério das Finanças no Japāo por exemplo);

Essas são as principais caracteristicas que diferem entre os dois modelos legais citados que podem impactar a contabilidade. Além desses pontos outros 
podem ser apontados estando relacionados com a estrutura geral de governança corporativa sem estar diretamente ligados com um ou outro sistema legal. Assim tem-se:

- custo de litígios: o custo esperado dos litígios que podem afetar administradores e auditores ${ }^{36}$ impactam diretamente a atitude destes em relaçāo a produçāo dos números contábeis. Profissionais trabalhando em ambientes nos quais este custo esperado é maior tendem a produzir números mais conservadores e fornecer quantidade menor de informaçōes qualitativas sobre o futuro da empresa em notas explicativas, por exemplo. No entanto, estudos empíricos ainda precisam ser realizados para verificar adequadamente tal relação. Conforme comenta FOSTER (1986: 36):

"Legal suits against the firm or its managers are an ever-present threat in today's litigious society. In some cases, this threat can operate to reduce disclosure. For instance, one argument against voluntary disclosure of earnings forecasts is that ex post they turn out to be overly optimistic; investors then may use the incorrect forecast as one basis to sue management to obtain reimbursement for a drop in the price of their equity investment. In other cases the threat of litigation can promote disclosure. As an example, assume that external parties such as security analysts make estimates of firmoriented variables that management views as "without foundation". The prompt public release of a corrective statement can reduce the potential losses to shareholders or reduce the potential exposure of the firm and its management in subsequent litigation."

\footnotetext{
${ }^{36}$ Custo esperado de litigios nessa literatura $C(L)$ refere-se ao efetivo custo dos litigios $\mathrm{C}$ multiplicado ao pela probabilidade de ocorrência $\phi$ dos vários estados da natureza $s$. Assim, tem-se $C(L)=\sum_{z} C \phi$. Essa consideraça é importante porque a probabilidade de ir aos tribunais tem o mesmo peso que o custo efetivo na determinação do comportamento dos agentes.
} 
Pode-se ver que está-se considerando que os custos dos litígios não dependem diretamente do modelo legal em questão; este aspecto, naturalmente, pode ser questionado.

- fontes de financiamento: empresas sediadas em paises onde a maior parte do financiamento advém do mercado de capitais tendem a possuir modelos de evidenciaçāo mais transparentes do que empresas em paises ou mercados que baseiam o financiamento fundamentalmente em débito. Isso ocorre porque os credores podem exigir, e realmente o fazem, informaçōes detalhadas não tendo que recorrer às demonstraçōes financeiras publicadas. Em situaçōes nas quais predomina o financiamento via mercado de capitais a evidenciaçāo deve ser mais clara para fornecer informaçōes ao grande número de acionistas que encontram-se dispersos no mercado. Essa relação impacta diretamente a contabilidade que é um instrumento de evidenciação;

- tamanho do mercado de capitais: o tamanho do mercado de capitais está diretamente relacionado ao item acima. Mercados maiores e mais desenvolvidos possuem empresas com bases acionárias dissolvidas. Esses acionistas demandam informações detalhadas para acompanhar o desempenho das empresas negociadas. Nesse tipo de relaçāo a contabilidade tem importante papel de redutora da assimetria informacional. Em mercados de capitais menos desenvolvidos com financiamento baseado em débito a contabilidade nāo possui esse papel uma vez que os interessados (credores) tem acesso privilegiado às informaçōes das empresas;

- sofisticação da base de investidores: mercados onde existe predominância de investidores institucionais, fundos de investimento ativos e outros investidores especializados, tendem a utilizar a informação contábil de forma diferente daquela presente em mercados nos quais a base de 
investidores é menos sofisticadas. HORTON (2000) observa que, especialmente no Reino Unido onde investidores sofisticados predominam, a apresentação das informações (forma dos demonstrativos) não importa. A velha discussão sobre o montante de informaçōes que deve constar das notas explicativas em detrimento do balanço não tem sentido em tais mercados. Uma vez que a informação é publicada os outros aspectos são detalhes. Outros autores apresentam evidèncias que a atençāo dada pelos analistas às empreas impacta diretamente o comportamento do preço das mesmas, conforme comentam HONG et all (2000:265):

"...once one moves past the very smallest stocks, the profitability of momentum strategies declines sharply with firm size. Sencond, holding size fixed, momentum strategies work better among stocks with low analyst coverage. Finally, the effect of analyst coverage is greater for stocks that are past losers than for past winners. These findings are consistent with the hypothesis that firm specific information, specially negative information, difuses only gradually across the investing public."

Essa linha de pesquisa indica que algumas propriedades da informação contábil sāo influenciadas e até mesmo determinadas pelos fatores acima. Mais especificamente, até o momento ${ }^{37}$ (BALL et all, 2000; BUSHMAN et all, 2000, as evidèncias permitem relacionar as seguintes propriedades da informação contábil com caracteristicas gerais de governança corporativa:

- relevância dos números contábeis: a contabilidade tende a ser mais relevante em paises onde existe predominância de financiamento por intermédio de mercado de capitais e acesso privilegiado à informaçōes é restrito. Naturalmente, a relevância da contabilidade dependerá também da existência de fontes altemativas de informação que competem com a

\footnotetext{
${ }^{37}$ Essa ressalva deve-se ao caráter extremamente recente da pesquisa neste assunto.
} 
informação emanada da contabilidade. A relevância dos números contábeis é investigada, dentro da perspectiva da informação, por intermédio do impacto da contabilidade nos preços das açōes negociadas em mercados de capitais. Assim, por relevante entende-se essa relação com os preços negociados que pode ser investigada por intermédio de vários modelos ${ }^{38}$. As evidências preliminares a esse respeito indicam que a relevância dos números contábeis não pode ser analisada de forma única. Resultado e patrimonnio ${ }^{39}$ parecem competir em termos de relevância dependendo das condiçōes de mercado. Em mercados mais ligados ao modelo de code-law com mercados de capitais menos desenvolvidos e controle acionário concentrado, tendem a apresentar valores de patrimônio mais acentuado do que o resultado contábil. Isso deve-se a importância contratual do património em casos de liquidaçāo nesses casos. O lucro é, normalmente, irrelevante devido a distorçāo de suas propriedades econômicas, como será visto nos dois itens abaixo;

- timeliness (oportunidade) da informação: Parece ser comum na estrutura conceitual do FASB, IASC, ASB e outros órgãos reguladores que a informação emanada pela contabilidade, especialmente o lucro, deve ser oportuna. Nesse sentido, oportunidade pode ser definida como a incorporação (reconhecimento) pela contabilidade do resultado econômico. Como demonstra BALL et all (2000) a seguinte relaçăo geral pode ser estabelecida para uma dada empresa $\mathrm{j}$ no periodo $\mathrm{t}$ :

$$
R C_{t j}=\beta_{o t j}+\beta_{1} R E_{t j}+\xi_{t j}
$$

Onde:

\footnotetext{
${ }^{38}$ Nesse trabalho utiliza-se o modelo de Ohlson.

${ }^{39}$ Variáveis mais tradicionalmente utilizadas.
} 
$\mathrm{RC}_{\mathrm{tj}}=$ Resultado contábil produzido dentro dos princípios geralmente aceitos no periodo t;

$\mathrm{RE}_{\mathrm{t}}=$ Resultado Económico ${ }^{40}$ (diferença de preço- ganho de capitalmais dividendos para empresas negociadas em bolsas de valores) para o periodo t;

$$
\begin{aligned}
& \beta=\text { Coeficientes do modelo } \\
& \xi_{t j}=\text { termo de erro }
\end{aligned}
$$

Nessa relaçāo os coeficientes determinam quão eficientemente a o resultado contábil reconhece o econòmico. O poder explicativo da regressão determina se o resultado econòmico realmente explica o comportamento do lucro contábil como seria esperado em um modelo contábil que tenta refletir a realidade económica. A evidência empirica a esse respeito (BALL et all, 2000) é claramente favorável à hipótese de que os parâmetros e o poder explicativo da regressão acima são significativamente diferentes entre paises que adotam modelo de common e code-law. Os primeiros apresentam lucro contábil reconhecendo efetivamente o resultado económico (parâmetros) bem como alto poder explicativo do resultado econômico em relaçăo ao resultado contábil. Esses resultados são consistentes com o papel da contabilidade nesses mercados;

- conservadorismo: o conservadorismo (também uma caracteristica qualitativa "desejável" segundo as estruturas conceituais básicas da contabilidade analisadas) significa em termos econômicos que o resultado

\footnotetext{
${ }^{10} \mathrm{O}$ RE nåo é apresentado em termos percentuais, assim $R E=\left(P_{t}-P_{t-1}\right)+$ dividendos. Onde $P_{t}$ e $P_{t-1}$ săo os preços das açð̋es da empresa (no caso do lucro contábil estar apresentado também por aça) em dois periodos imediatos. Essa definiça de resultado econômico segue a definiçao geral fornecida no clássico de Hicks (1946).
} 
contábil é produto de um processo de "reconhecimento assimétrico" do resultado econômico. Isso ocorre devido às práticas contábeis de superestimar despesas e passivos e subestimar ativos e receitas. Isso significa que o resultado contábil é mais sensivel à resultados econômicos negativos do que positivos. O teste dessa premissa é realizado por intermédio da inclusão de variáveis dummy com o valor de 1 (um) no caso de resultado econômico negativo e 0 (zero) para resultados positivos à equação acima ${ }^{41}$. Por intermédio dessa especificação verifica-se se o resultado contábil é mais sensivel aos resultados negativos do que aos positivos. Novamente, a evidência (BALL et all, 2000) demonstra que em paises que adotam sistemas de common-law com mercados de capitais desenvolvidos e modelos de controle acionário baseados na figura do shareholder e não do stakeholder, o resultado contábil é mais sensivel ao resultado econômico negativo. Essa evidência deve-se à necessidade de incorporaçāo imediata de resultados negativos no resultado devido à disciplina aplicada pelo mercado e pelos acionistas minoritários. Empréstimos e outros ativos claramente sem substância econòmica (sujeitos ao impairment) não são comuns em paises como os Estados Unidos e o Reino Unido ao contrário do que ocorre, por exemplo, no Japão;

Além dessas caracteristicas da contabilidade que sāo influenciadas pela estrutura de governança corporativa existente, outros autores tem argumentado que a contabilidade pode influenciar os mecanismos de governança estabelecendo a relação inversa da apresentada acima. BUSHMAN et all (2000) argumentam que em empresas que possuem números contábeis ineficazes em capturar o impacto das atividades realizadas no valor da empresa para os acionistas a contabilidade possui papel reduzido no sistema de governança. Nessas empresas, onde a contabilidade não cumpre o seu papel, mecanismos caros e sofisticados de governança devem ser estabelecidos para compensar tal

${ }^{41}$ Maiores detalhes dessa formulaçăo podem ser vistos no capitulo 4. 
deficiència. Os resultados sugerem que em empresas com números contábeis mais "pobres" em termos informativos a estrutura de governança é mais cara e maior. Esse tipo de pesquisa ainda é muito recente e apresenta problemas com a definição operacional das variáveis. Apesar desses problemas os resultados encontrados possuem implicações importantes para os estudos da interface de governança corporativa com a contabilidade.

Apesar do caráter embrionário das pesquisas realizadas tentando correlacionar a contabilidade com os problemas de governança corporativa, a mensagem fornecida é bem clara: a relevância da informação emanada pela contabilidade não pode ser avaliada completamente sem a consideracão dos mecanismos de governança corporativa. A desconsideraçāo desses aspectos empobrece a análise realizada uma vez que possiveis causas do comportamento empirico reportado podem ser esquecidas ou simplesmente não estudadas.

Para as finalidades deste trabalho, duas conclusōes acerca da inter-relação entre contabilidade e governança corporativa são relevantes. Inicialmente, é importante ressaltar a função informacional do lucro. Segundo BALL et all (2000) e BUSHMAN et all (2000) o lucro contábil possui a funçāo de redutor da assimetria informacional entre investidores e administradores. Em mercados onde os investidores não possuem acesso privilegiado às informaçōes e o controle das empresas está disperso em uma grande base de acionistas (mercados como o inglês e o americano, por exemplo), espera-se que o lucro seja mais relevante (relacionado com o comportamento dos preços) do que em mercados onde 0 controle esteja concentrado em acionistas que possuem acesso "especial" às informaçōes (caso do modelo alemāo e japonès, por exemplo). As evidências empiricas encontradas até momento são fortemente favoráveis às hipóteses acima. Em segundo lugar, o papel do patrimônio também merece ser adequadamente avaliado. Em muitos paises (caso do Brasil, por exemplo), em casos de falência das empresas, os acionistas são os últimos a ter acesso aos ativos liquidados da mesma. Existe uma hierarquia de recebimento que coloca 
empregados, governo, credores com garantias, credores quirografários e outros em posição privilegiada em relação aos acionistas. Dessa forma, os acionistas somente terāo direito ao recebimento de seus haveres quando todos os ativos forem realmente liquidados. Assim, o patrimònio (apesar de não ser baseado em valores de liquidação e sim em uma base de custo histórico para a maior parte dos ativos e passivos) parece fornecer uma proxy confiável para os montantes a serem recebidos em casos de liquidação. Novamente, essa conclusão é validada pelas evidèncias presentes na literatura.

No último caso, observa-se uma interligação real entre a relevância dos números contábeis e o arcabouço juridico subjacente. Essa ligaçāo é natural, uma vez que o corpo legal pode impor relevância à informaçōes emantadas da contabilidade que não seriam esperadas dentro de um ponto de vista puramente econòmico.

\subsection{A Contabilidade no Mercado Brasileiro}

Para a finalidade deste trabalho algumas caracteristicas do mercado de capitais brasileiro e da produçāo e disseminação de informaçōes contábeis precisam ser adequadamente definidas ${ }^{42}$. Assim, tem-se os seguintes aspectos relacionados, inicialmente, com a contabilidade em seguida com as caracteristicas do mercado de capitais brasileiro.

\subsubsection{Características Estruturais da Contabilidade Financeira no Brasil}

A contabilidade financeira no Brasil possui caracteristicas bastante interessantes e diferenciadas dos modelos tradicionalmente apresentados na literatura (principalmente o norte-americano). A discussāo seguinte procura abordar as principais características da contabilidade financeira no Brasil:

\footnotetext{
$42 \mathrm{Na}$ foram realizadas pesquisas primárias nesta seçao. Isso deve-se aos objetivos do trabalho e ao fato da maioria dos resultados apresentados estarem bem reportados na literatura.
} 
regulamentação, participação da profissão no processo de regulamentação e o impacto da legislaçāo tributária na contabilidade ${ }^{43}$.

\section{Regulamentação:}

A contabilidade financeira no Brasil é extensamente regulamentada. As empresas com açōes negociadas em bolsas de valores (sociedades anônimas) devem seguir a Lei $\mathrm{N}^{0} 6.404^{44}$ de 1976 que fornece os principais conceitos que devem ser utilizados na contabilização das operaçōes realizadas por essas instituiçōes. Essa Lei é a base conceitual para a contabilização das operaçōes e suas orientaçōes sāo seguidas pelos auditores no processo de verificaçāo da adequação das contas das empresas aos principios contábeis geralmente aceitos. Além da referida Lei, instituiçōes atuando em setores específicos de atividade no Brasil possuem contabilidade regulamentada especialmente. É o caso das instituiçōes financeiras e o Plano Contábil do Sistema Financeiro Nacional (COSIF) do Banco Central do Brasil, das Entidades Fechadas de Previdència Privada e o Plano de Contas fornecido pela Secretaria de Previdència Complementar (SPC) e das entidades de seguros privados e capitalização que devem seguir as normas contábeis da Superintendència de Seguros Privados (SUSEP). No caso das instituições financeiras, mais importantes para este trabalho pois possuem açōes negociadas na Bolsa de Valores, o COSIF é levado ao mercado por intermédio de circulares sendo um normativo extremamente detalhado contendo, inclusive a numeração das contas contábeis. Dessa forma, observa-se uma total padronizaçāo da contabilidade dessas instituiçōes. A autoridade para estruturar o COSIF cabe inteiramente ao Banco Central do Brasil. Apesar desse órgão poder ouvir as demandas do mercado em suas Audiências Públicas e demais mecanismos com esse intuito a autoridade final sobre a

\footnotetext{
${ }^{43} \dot{E}$ importante ressaltar que esta é uma discussăo sucinta focando nos tópicos de interesse do trabalho sem o objetivo de esgotar 0 assunto.

4 O referido normativo é bastante amplo e trata das principais matérias (juridicas, societárias, etc) relacionadas ao mercado de capitais brasileiro não estando restrita somente à contabilidade. Essa Lei é o principal instrumento legal de orientaça em relaçào às atividades de mercado de capitais no Brasil.
} 
contabilidade dessas instituiçōes cabe exclusivamente ao Banco Central. É um processo unilateral com o mercado.

A Comissão de Valores Mobiliários (CVM) tem autoridade residual em relaçāo à Lei. Essa Comissão também acaba por normatizar assuntos contábeis menos abrangentes do que os contidos na Lei e também atua em assuntos que não estão totalmente claros (tratamento dos prejuizos relacionados com a desvalorização cambial ocorrida em 1999, por exemplo). Instituiçōes financeiras devem aderir ao COSIF e em adiçāo às normas da comissão de valores mobiliários. Esse modelo contrasta com o existente em paises como Estados Unidos, Reino Unido, Canadá, Austrália e outros onde a contabilidade é regulamentada pela iniciativa privada sem intervençāo direta do governo, mesmo que este possua a autoridade residual (como no caso da SEC nos EUA).

Nesse tipo de modelo contábil é natural que a contabilidade atenda ao seu usuário principal (ou pelo menos aquele que detém o poder de regular): 0 Governo. Assim verifica-se, por exemplo, que a padronizaçāo total no COSIF atende principalmente ao Banco Central na medida que facilita o processo de fiscalizaçāo. Não existem evidências de que a padronizaçāo produz informaçōes mais relevantes para o mercado, muito pelo contrário. Esse aspecto, individualmente, leva a hipótese que a produção de informaçōes contábeis pelas instituiçōes financeiras no Brasil não apresenta conteúdo informativo para o mercado.

\section{Participação da profissão no processo de regulamentação}

A participação da profissāo contábil no processo de regulamentaçāo da contabilidade no Brasil é pequena. Conforme observado acima, as normas contábeis no Brasil advém exclusivamente de fontes governamentais sem a existência de um corpo independente ativo (como o caso do FASB norteamericano ou do ASB britânico). Apesar de não serem conhecidas evidências 
empiricas do impacto desse cenário na qualidade da informaçăo contábil no Brasil, internacionalmente muitos estudos têm sido realizados nesse sentido. Conforme BALL et all (2000) documentam, paises onde a profissão contábil não possui influência direta na normatização da contabilidade (Japão, Alemanha e França por exemplo) as informaçōes emanadas pela contabilidade não possuem conteúdo informativo relevante para os investidores.

No entanto, como tantos outros aspectos da contabilidade financeira, evidèncias empiricas sāo necessárias para avaliar o real impacto da participaçāo da profissão. Alguns aspectos da realidade brasileira sugerem que, apesar de pequena, a participação da profissão no processo de regulamentaçāo pode ter produzido resultados importantes como no caso da correção monetária integral. Conforme DOUPNIK, MARTINS e BARBIERI (1995: 302) comentam:

"A comparison of the two methods ${ }^{45}$ demonstrates the conceptual superiority of the IMCS. The IMCS is also shown to be conceptually superior to traditional methods of accounting for inflation."

A existência de exceçōes como a mencionada acima demonstra que o impacto da profissāo nas normas contábeis no Brasil ainda é objeto de investigaçāo empirica futura. A própria revogação da correção monetária no Brasil (Lei No 9555/1995) demonstra a ingerência direta do governo, nesse caso o federal, nos assuntos contábeis sem que haja uma justificativa técnica. Aparentemente, este aspecto contribui para a baixa qualidade das normais contábeis no Brasil, sob o ponto de vista dos investidores em mercados de capitais. Tais investidores também possuem papel limitado no processo de regulamentaçāo da contabilidade no Brasil pelos motivos apresentados acima. Esse cenário difere de paises onde as normais contábeis são emanadas por órgãos privados que agregam a participação de representantes de diversos setores do mercado. 


\section{Impacto da legislação tributária na contabilidade}

A legislação tributária também impacta fortemente a formação das informaçōes contábeis no Brasil. Isso ocorre via a utilização de métodos contábeis determinados pela autoridade fiscal no processo de evidenciação para o mercado de capitais. O caso mais clássico desse fenômeno no Brasil é a utilização de limites fixos para a constituiçăo de provisāo para devedores duvidosos (PDD). O valor normalmente utilizado pelas empresas era justamente o máximo permitido fiscalmente. Esse é um problema para os investidores porque a PDD é uma forma utilizada pelas empresas para fornecer informaçōes ao mercado a respeito de suas atividades (nesse caso a qualidade de seus ativos), reduzindo assim a assimetria informacional. A fixaçāo de um dado valor para essa conta impossibilita esse processo.

A utilização de normais tributárias no processo de evidenciação das empresas negociadas em mercado de capitais possui impactos negativos do ponto de vista dos investidores, mesmo que as regras utilizadas sejam consideradas tecnicamente 'adequadas'. Isso ocorre porque o processo discricionário de escolha de práticas e métodos contábeis é parte integrante do processo de comunicaçăo entre administradores e investidores reduzindo a assimetria informacional no mercado o que contribui para maior eficiência. Dessa forma, o impacto de orientaçōes tributárias na contabilidade financeira nāo contribui para o fornecimento de informaçōes para investidores e demais usuários. Esse aspecto contribui para reduzir a qualidade da informaçăo contábil produzida no Brasil. Como comenta da COSTA (1993:13) a respeito das demonstraçōes contábeis produzidas pelas empresas brasileiras:

"...are used with little effectiveness by corporations that usually comply merely with their legal obligations."

${ }^{45}$ System of Monetary Correction (SMC ou sistema de correção monetária, societária) e Integral Mfonetary 
Outros autores vāo mais longe nas críticas como pode ser visto em PEREIRA (1990:30-31):

"...para a vasta maioria das empresas, as demonstraçōes financeiras nāo correspondem à realidade de suas operações."

Do mesmo autor:

"...a manipulaçāo das demonstrações financeiras nāo é restrita às pequenas empresas."

Os aspectos citados acima levam ao levantamento da hipótese de que as informaçōes contábeis não fornecem informaçōes relevantes para o processo de tomada de decisões no mercado de capitais brasileiro.

\subsubsection{Mercado de Capitais no Brasil}

As condições gerais de funcionamento e governança corporativa no mercado de capitais brasileiro impactam diretamente, conforme discutido acima, o papel da contabilidade na explicaçāo do comportamento dos preços negociados. Nessa seção serāo analisados de forma sucinta os principais aspectos do mercado brasileiro que, segundo a percepçāo do autor, podem ajudar a compreender a importância da contabilidade.

\section{Controle Acionário e Arcabouço Institucional}

A estrutura de controle acionário das empresas negociadas é ponto central no entendimento do papel da contabilidade no mercado de capitais. Dois aspectos são relevantes conforme já comentado sucintamente: (i) concentração do capital 
votante e (ii) tratamento dos acionistas minoritários. O primeiro aspecto é relevante porque um dos papéis fundamentais da contabilidade no mercado de capitais é reduzir a assimetria de informaçāo entre acionistas e gestores. Em empresas com poucos acionistas (que normalmente tem grande influência na administração) a contabilidade perde esse papel. Tais acionistas nāo precisam da contabilidade para obterem informaçōes sobre as empresas das quais fazem parte. $O$ tratamento dos minoritários é relevante porque a contabilidade tende a atender primordialmente a esses acionistas que normalmente estāo privados de qualquer acesso especial às informaçōes das empresas. $A$ ausência de uma base significativa de acionistas minoritários participantes reduz a demanda por informaçōes contábeis com relevância para o mercado de capitais.

A importância do tratamento dos acionistas minoritários na formaçăo de preços em mercados de capitais está bem documentada na literatura em governança corporativa. GOMES ${ }^{46}(2000: 615-616)$ comenta:

"Recent empirical research indicates that in many countries the relevant corporate finance issue is not the traditional agency problem between managers and shareholders, but rather the agency problem between the controlling shareholders and the minority shareholders. This problem may arise in some countries for two reasons: (1) the corporate governance structure of public companies insulates large shareholders-that is, those with a majority of the votes and often with an involvement on the firm's management-from takeover threats or monitoring; and (2) the legal system does not protect minority shareholders because of either poor laws or poor enforcement of laws.

Despite the lack of protection for minority shareholders, the average ratio of stock market capitalization held by minorities to gross national

\footnotetext{
${ }^{46}$ Nota somente para ressaltar a feliz participacaao de um autor brasileiro nesse debate.
} 
product is greater than 40 per cent for a sample of 49 countires. This raises the question of why people are willing to be minority shareholders when they know that neither corporate governance mechanisms, such as takeovers and monitoring, nor laws protect them form expropriation by large shareholders.

...the answer to the puzzle about people's willingness to be minority shareholders is: firms can sell shares to minority shareholders even without any explicit mechanism of governance because managers are able to commit implicitly no to expropriate shareholders. In other words, managers can develop a reputation for treating minorities shareholders well."

A concentração do controle acionário no Brasil é bastante grande. Em pesquisa recente realizada pela Empresa Economática e publicado no jornal GAZETA MERCANTIL (22 de Dezembro de 2000:C-1) mostra que "na maior parte das companhias que tèm apenas ações ordinárias, mais de $70 \%$ do capital está em poder de um único acionistan. Segundo o relatório publicado pela Mckinsey (MCKINSEY \& COMPANY: From Local Control to Global Influence, 2000: 18) 95\% das empresas negociadas na BOVESPA possuem 3 ou menos acionistas com mais de $50 \%$ dos direitos de voto. Essa concentração, naturalmente, faz com que o mercado pague pouco, comparativamente, para ter direito a voto no Brasil como demonstram os dados da Economática. Essa alta concentraçāo do mercado de capitais nacional possui implicaçōes diretas para a contabilidade. Em empresas com poucos acionistas (no caso brasileiro em muitas empresas o controle acionário está nas mãos de um único acionista) a contabilidade perde seu papel de redutora da assimetria de informaçāo entre acionistas e gestores. Nessas empresas o acionistas majoritário possui acesso privilegiado às informaçōes gerenciais da empresa não necessitando da contabilidade para orientar suas decisōes de investimento. No Brasil é situaçāo ainda é mais extrema com muitas 
empresas fechando o capital. Somente durante 0 ano de 2000 as seguintes deixaram de ser negociadas na BOVESPA: Agrale, White Martins, Arno, Durex Industrial, Abril, Ceval e Lojas Brasileiras.

A proteção dos acionistas minoritários tem sido objeto de intenso debate na imprensa especializada no Brasil e exterior (GAZETA MERCANTIL, 22 de Dezembro de 2000:C-1 e FINANCIAL TIMES, 20 de Dezembro de 2000: 14). Apesar de poucas evidèncias empiricas nesse aspecto, pode-se perceber, como comenta LUZ:2000:1-8) que os acionistas majoritários tèm praticado 'abusos' em relaçāo aos minoritários. Segundo esse autor, os principais problemas são:

- alienação de ativos da empresa por valores inferiores ao de mercado para outra companhia de propriedade do controlador e/ou administrador;

- emprego de pessoal não qualificado;

- implementação de projetos para o atendimento de interesses privados;

- elevadas remunerações pagas aos administradores;

Apesar desses aspectos serem de dificil generalizaçāo empirica, as discussōes levando às alteraçōes na Lei das Sociedades Anônimas tem sido centradas na questāo da redução do número de açōes ordinárias que podem ser emitidas pelas empresas. Esse aspecto é extremamente importante, uma vez que a emissāo de ações preferenciais reduz o poder dos acionistas minoritários diretamente. Além desses aspectos a proposta de alteração da Lei das Sociedades Anônimas inclui a obrigatoriedade de um dividendo obrigatório bem como a participaçāo dos acionistas minoritários no conselho de administraçāo das empresas. A obrigatoriedade de dividendos, como comentado anteriormente por La PORTA et all (2000: 9-10), é um sinal de que os acionistas minoritários não sāo protegidos pelo sistema legal existente. 
$\mathrm{Na}$ realidade, o tratamento dos acionistas minoritários no Brasil somente reflete o alto grau de instabilidade institucional no Brasil. Segundo NORTH (1990) a estabilidade institucional é importante pois reduz os custos de definição dos direitos de propriedade, mensuração dos atributos de troca e efetiva implementaçāo dos contratos. Segundo esse autor algumas instituiçōes que facilitam a contratação no mercado financeiro são:

- enforcement judicial ou semi-judicial;

- práticas contábeis e de evidenciação;

- auditores agências de avaliação de crédito;

- mercados eficientemente organizados;

- órgãos de regulamentação que promovam integridade no mercado.

No caso brasileiro, aparentemente, existem problemas em todos os itens acima. Como comenta NORTH (1990:59)

"There is a immense difference in the degree to which we can rely upon contract enforcement between developed countries and third world countries"

Esses aspectos são bem percebidos pela literatura financeira internacional como comenta ANDERSON (1999:53-54):

"Brazil's institutions are far from primitive, but they appear insufficiently developed to substantially assit parties to financial contracts. First, Brazil has a civil-law legal tradition, characterized... 
as an impediment to external financing in general. The Brazilian legal system, in particular, does not imply the principle of stare decisis and the judiciary is regarded as inefficient and sometimes even corrupt. Second, the quality of disclosure by Brazilian firms is perceived to be low. South American accounting practices are dominated by the legal and administrative systems inherited from lberian colonizers and the 'highly political environment that result from such systems'. Third, ancillary disclosure institutions are weak. Fourth, thin trading and volatile pricing characterize Brazilian financial markets. Finally, Brazilian regulators do not provide the same guarantee of financialsystem soundness as that enjoyed in developed countries. Reflecting Brazil's weak institutional environment, Transparency International's inaugural Corruption Perception Index ranked Brazil $37^{\text {th }}$ out of 41 rated countries"

Assim, neste trabalho assume-se que as condiçōes institucionais no mercado brasileiro não são as mais propicias para o a realização de operaçōes financeiras. ANDERSON (1999:49) resume esse cenário:

"The environment in Brazil appears to be inimical to financial contracting"

Outro aspecto que contribui para a instabilidade institucional no Brasil é a alta volatilidade da atividade econômica real, refletida no fluxo de caixa das empresas e nos preços das açōes negociadas no Brasil. Conforme ANDERSON (1999:52) comenta;

"Over the this tem-year period (1984-1993), the compound annual dolar return on the BOVESPA index is $16.9 \%$ compared to $11 \%$ on the S\&P. However, the standard deviation of monthly returns is $25.3 \%$ for the BOVESPA index, considerably higher than the $4.5 \%$ 
monthly standard deviation of the S\&P 500. Brazil's economic uncertainty is also reflected in measures of country risk, such as Institutional Investors' County Credit Risk Index, in which Brazil is never ranked better than $60^{\text {th }}$ out of all rated countries between 1989 and 1993."

Adicionalmente, os altos níveis de inflação existentes no Brasil até meados da década de 1990 contribuiram para o agravamento dessa situação de instabilidade. Para resumir essa seção, apresenta-se a seguinte tabela extraída de ANDERSON (1999:50):

\section{FIGURA 5}

Performance do Brazil em Várias Classificações de Risco

\begin{tabular}{|c|c|c|}
\hline Country Risk Measure (source) & Brazil's rating & Brazil's ranking \\
\hline $\begin{array}{l}\text { Country Credit Risk (Institutional } \\
\text { Investor): average rating } 1989-1993\end{array}$ & 27.4 out of 100 & $\begin{array}{l}\text { Never better than } 60^{\text {th }} \text { out of } \\
\text { rated countries }\end{array}$ \\
\hline $\begin{array}{l}\text { Intemational Country Risk Guide } \\
\text { (Political Risk Services): average } \\
\text { ratings, 1989-1993 }\end{array}$ & 100 & $\begin{array}{l}\text { Never better than } 53^{\text {r }} \text { out of } \\
\text { nearly } 130 \text { rated countries }\end{array}$ \\
\hline $\begin{array}{l}\text { Comuption } \quad \text { Perception Index } \\
\text { (Transparency } \text { Intemational): inaugural } \\
\text { index } 1995\end{array}$ & $2.7 \mathrm{c}$ & 37 \\
\hline $\begin{array}{l}\text { The Index of Economic Freedom: } \\
\text { Inaugural index } 1995\end{array}$ & $\begin{array}{l}3.30 \text { out of } 5 \\
\text { ( } 1 \text { best, } 5 \text { worst) }\end{array}$ & $63^{\text {rd }}$ of 101 rated countries \\
\hline
\end{tabular}

\section{Fontes de Financiamento}

As fontes de financiamento das empresas sāo de fundamental importància para a análise do papel da contabilidade. Apesar de fomecedores de crédito utilizarem informaçōes contábeis tāo intensamente quanto os investidores em mercado de capitais, o foco deste trabalho está direcionado para os fornecedores 
de capital e não de dívida. O desenvolvimento econômico no Brasil vinha sendo sustentado, desde meados da década de 50, fundamentalmente com crédito. Esse cenário vem se modificando ao longo dos anos 90 conforme comenta STUDART (2000: 25)

"Since the 1950's, the financing of economic development in Brazil has relied significantly on selective credit policies, inflationary financing and external saving. We claim that in the 1990's and for the first time in its pos-war history, due to the developments both in the international and in the domestic financial markets, there existed opportunities to develop non-inflationary private sources of long term finance and to reduce its dependency on foreign savings. These opportunities have been so far spared due to the lack of policies towards enhancing some of the positive aspects of recent developments in Brazil's financial systems, and avoiding excessive volatility and instability of financial markets."

Várias medidas adotadas pelo governo federal vèm focando 0 desenvolvimento de poupança interna e o desenvolvimento de instrumentos que propiciem o 'crescimento sustentado' no mercado brasileiro. Para as finalidade deste trabalho basta o reconhecimento do relatado acima.

\section{Participação do Estado na Economia}

A participação do estado na economia brasileira tem impacto direto no papel da contabilidade para explicar o comportamento dos preços no mercado. Isso ocorre porque a maior participaçāo do estado na economia vem, normalmente, associada com a atrofia do setor privado como fornecedor de crédito e capital para as instituiçōes que atuam no mercado. Esse açāo reduz a demanda por informaçōes contábeis uma vez que um órgāo centralizador coordena grande parte das atividade empresariais. No caso brasileiro existe uma 
exacerbação do problema com o estado participando, de forma intensa até muito recentemente, dos setores financeiro, petróleo, mineração, telecomunicaçōes, geração de energia, transportes e outros. Além dos problemas naturais advindos da participação tāo intensa do estado na economia, surgem outros agravantes oriundos da forma com que esse realiza tais intervençōes. Como comenta ANDERSON (1999:54):

"...the government frequently responds to high inflation, volatile growth and capital flight with sweeping heterodox policies characterized by reliance on wage and price controls. These economic plans (Cruzado Plan, 1986; Bresser Plan, 1987; Summer Plan, 1989; Collor I, 1990; Collor II, 1991; Real Plan, 1994) substantially revise the fundamental rules of the game for transactions among private parties. In particular, these plans often unilaterally amend contract terms, particularly inflation indexation. These plans affect a financial contract directly when its terms are altered by government fiat and indirectly when other contracts are manipulated."

Essa instabilidade institucional leva ao aumento extremo da assimetria de informação entre os agentes causando extrema dificuldade na contratação. Em última análise esse problema pode levar à completa imobilizaçāo do mercado de capitais.

O governo brasileiro tem atuado em um programa de desastização de suas empresas e abertura aos investimentos estrangeiros. A abertura relativamente recente $^{47}$ (iniciada em 1991 para operaçāo de fundos, introduçāo de American

\footnotetext{
${ }^{47}$ Em Maio de 1991 A Resolução N0 1832 Anexo IV (conhecida no mercado simplesmente como "anexo IV") estipulou que instituiçðes estrangeiras podem possuir até $49 \%$ das açðes votantes e $100 \%$ das açðes nưo votantes das empresas nacionais. Desde entāo o cenário para investimentos estrangeiros no Brasil tem evoluido muito no sentido da maior abertura no mercado nacional.
} 
Depositary Receipts em 1992, etc.) do mercado de capitais brasileiro ${ }^{48}$ possui importância central no comportamento dos preços no Brasil. HENRY (2000:529) comenta o assunto da seguinte forma:

“On average, a country's aggregate equity price index experiences abnormal returns of 3.3. percent per month in real dollar terms during na eight-month window leading up to the implementation of its initial stock market liberalization. This result is consistent with the prediction of standard international asset pricing models that stock market liberalization may reduce the liberalizing country's cost of equity capital by allowing for risk sharing between domestic and foreign agents."

A participaçāo do estado na economia brasileira pode ser analisado dentro de várias perspectivas. No entanto para as finalidades deste trabalho, o aspecto que deve ser ressaltado é que a economia brasileira possui grande participaçāo do estado e que essa participaçāo, bem como a forma pela qual é realizada, inibe a atividade financeira organizada como esta é conhecida nos paises desenvolvidos.

\footnotetext{
"Definida neste trabalho conforme HENRY (2000: 529) "A stock market liberalization is a decision by a country's government to allow foreigners to purchase shares in that country's stock markets."
} 


\section{HIPÓTESES DO TRABALHO}

Este trabalho procura investigar o papel da contabilidade no mercado de capitais brasileiro. Mais especificamente a questão de pesquisa é a seguinte:

\section{Qual a relevância da contabilidade para explicar o comportamento de preços das açōes negociadas na Bolsa de Valores de São Paulo (BOVESPA)?}

Essa pergunta, como a maior parte das questōes em estudos empíricos em contabilidade financeira, pode ser analisada dentro de duas estruturas básicas segundo HARRIS et all (1994:194):

"Studies on the value relevance of accounting earnings have traditionally followed two approaches. One approach focuses on the market reaction to unexpected earnings....An alternative approach for testing the information content of accounting data is to analyse the association between stock data and accounting earnings over longer windows."

Este trabalho opta pela segunda modelagem utilizando como base o modelo de OHLSON (1995) ${ }^{49}$. Essa classe geral de estudos baseada em dados em cross section é utilizada especialmente em mercados nos quais o fluxo de informaçōes não é tão perfeito como nos mercados mais desenvolvidos. Dessa forma, a escolha de modelos do tipo event study poderia mascarar o real comportamento dos dados. Como observam HARRIS et all (1994):

\footnotetext{
49 Modelos como esse que analisam o impacto de variáveis contábeis no preço de açðes negociadas em bolsas de valores para um dado periodo considerando um grande número de empresas (cross sectional analysis) sảo também chamados de estudos de nivel (level studies).
} 
"We do not follow this approach (event studies) for several reasons. First...the ownership structure of German firms creates the possibility that information dissemination occurs prior to the press-release date. Therefore, a testing using a short window around the earnings announcements date for any other date) is affected by both the value relevance of the information released and its timing. Given that our interest is primarily in the value relevance of the information, we focus on a longer window where the timing of information dissemination is less of an issue. Relatedly, the appropriate earnings expectation modelo is not clear, and tests using longer windows are less sensitive to the earnings expectations used."

Pode-se considerar que as razões acima adequam-se ao caso brasileiro devido à estrutura acionária do mercado nacional como pode ser visto no item 3.5.2 do capitulo anterior. Assim a escolha da modelagem utilizada aqui elimina, ou pelo menos reduz significativamente, os problemas causados pelo fluxo de informaçōes no mercado brasileiro. Este capitulo apresenta o detalhamento dos testes quantitativos realizados bem como a definiçāo clara das variáveis empregadas. Nesse trabalho a questāo de pesquisa central é dividida em três hipótese relativas ao (i) papel do resultado contábil e dos dividendos na avaliação do preço das açōes negociadas na BOVESPA, (ii) poder explicativo de resultados contábeis e patrimônio em termos dos preços negociados e (iii) reconhecimento do resultado econômico pelo resultado contábil $e$ assimetria neste reconhecimento. A conclusão do trabalho depende dos resultados conjuntos das três hipóteses apresentadas. Por outro lado, com a finalidade de enriquecer o trabalho e a robustez dos resultados, essas três hipótese foram subdividas para o periodo de 1995-1999. Dessa forma, as equaçōes apresentadas abaixo serão avaliadas em conjunto. 
É importante relacionar a questāo central de pesquisa com as três hipóteses testadas. Na maior parte dos trabalhos analisados na revisão da literatura para esta tese, nos quais a pergunta central relaciona-se com o papel da contabilidade para o mercado financeiro, tal pergunta tem sido respondida com a utilização de somente uma especificação quantitativa. Neste trabalho são utilizados três abordagens que refletem aspectos distintos do papel da contabilidade nos mercados financeiros. A razão para a utilização dessa abordagem é a de descrever mais amplamente o comportamento do mercado brasileiro em termos de informaçōes contábeis.

A primeira hipótese tenta comparar dois modelos de avaliação: o modelo de OHLSON (1995) e o modelo do valor presente dos dividendos descontados. O objetivo de tal análise é comparar, dentro da estrutura proposta por OHLSON (1995), as informaçōes contábeis de patrimônio e resultados anormais com os dividendos pagos em termos de avaliaçāo das açōes das empresas. A verificaçāo de que os números contábeis possuem poder explanatório comparável, ou superior aos dividendos, leva a conclusão de que a contabilidade é relevante para avaliação de empresas no Brasil. Como relevante entende-se poder explanatório pelo menos comparável com os dividendos que são considerados tradicionalmente na literatura de finanças como elementos principais na avaliação de empresas. A segunda hipótese compara o poder explicativo das variáveis contábeis em relação ao preço das ações das empresas correspondentes. Nesse caso compara-se a relevância dos números contábeis em relação ao restante do conjunto de informações à disposiçāo dos agentes econômicos. Os resultados dessa seção são especialmente importantes uma vez que resultados positivos demonstram que as informaçōes emanadas da contabilidade realmente contribuem para o conjunto de informações à disposição dos investidores. Novamente, o modelo de OHLSON (1995) é utilizado dentro de uma especificação proposta por COLLINS et all (1997) que, de forma simplificada, relaciona os valores de lucro e patrimônio do final do período (variáveis independentes) com o preço de mercado (variável dependente) cotado quatro meses após o final do ano 
fiscal (período) correspondente. Finalmente, aplica-se o modelo proposto por BASU (1997) e ampliado por BALL et all (2000) que procura estabelecer a oportunidade (timeliness) do reconhecimento do resultado econômico (variável independente) pelo resultado contábil (variável dependente). Esse teste complementa os dois primeiros na medida que estabelece quão efetivo o lucro contábil é em reconhecer o resultado econômico bem como avalia o papel do reconhecimento assimétrico (conservadorismo) no processo. A utilização dessas três especificações fornece uma fotografia ampla do comportamento do mercado brasileiro em relação à informação contábil dentro do periodo considerado.

Além da utilização de três modelos distintos para o estudo da questão de pesquisa, são utilizadas várias regressões referentes a periodos diferentes para avaliar as três hipóteses de trabalho. Tal ação é feita com o objetivo de mitigar uma das principais criticas acerca da pesquisa empirica em contabilidade financeira: a de que os resultados são localizados e não refletem a realidade econômica subjacente. É importante ressaltar que a utilização de técnicas quantitativas, como as regressões lineares utilizadas neste trabalho, não confere 0 caráter objetivo que as ciências exatas gozam naturalmente. As conclusões de trabalhos como este, que relacionam números contábeis com preços em mercados de capitais, sempre serão extremamente dependentes da interpretação dos autores. Nesse sentido, a maior amplitude dos estudos realizados levando em consideração um número maior de periodos, envolvendo amostras mais representativas da realidade estudada, aumenta 0 poder dos resultados encontrados em termos de explicação da realidade estudada.

Assim, esta seção pretende apresentar a transformação das hipótese de estudo em modelos quantitativos que podem ser testados empiricamente. 


\subsection{Mensuração: Lucros e Dividendos}

A primeira hipótese do trabalho procura comparar a informação fornecida pela contabilidade com àquela advinda dos dividendos no processo de avaliação dos titulos negociados no mercado. Mais especificamente:

$H_{0 a}$ : a avaliação baseada em resultados contábeis futuros é tão relevante quanto aquela baseada em dividendos futuros.

Para a avaliação desta utiliza-se o modelo de OHLSON (1995) dentro da especificação fornecida por BERNARD $(1995)^{50}$ que apresenta a seguinte estrutura:

$$
P_{i j}=\beta_{0}+\beta_{1} B V_{i j}+\beta_{2} A b_{i j+1}+\beta_{3} A b_{i j+2}+\beta_{4} A b_{i j+3}+\beta_{5} A b_{i j+4}+\varepsilon_{i j}
$$

Onde:

$P_{i j}=$ preço das ações da empresa $\mathrm{i}$ ao final do ano $\mathrm{j}$.

$B V_{i j}=$ patrimônio (book value) por ação da empresa $\mathrm{i}$ ao final do ano $\mathrm{j}$.

$A b_{i j+1}, A b_{i j+2}, A b_{i j+3}, A b_{i j+4}=$ Resultado contábil anormal (calculado de acordo com OHLSON) para os anos $j+1, j+2, j+3$ e $j+4$ respectivamente $^{51}$.

$\varepsilon_{i j}=$ termo de erro da regressão.

\footnotetext{
${ }^{50}$ Os dois trabalhos foram publicados no mesmo ano, mas o trabalho de OHLSON circulou durante muitos anos como um working paper, sendo amplamente citado e utilizado antes de sua publicação efetiva.
} 
Essa especificação é uma tentativa de operacionalizar o modelo geral. Algumas premissas importantes são assumidas para que a implementação possa ser realizada. Inicialmente, a especificação linear é mantida por intermédio da utilização de uma regressão linear múltipla. O segundo ponto relevante é a consideração do preço a ser avaliado (variável dependente) como o preço médio do último mês do ano fiscal analisado (Dezembro para as finalidades do trabalho) para evitar impactos extremos que poderiam surgir na escolha de um único dia. $O$ valor do patrimônio é apresentado por ação (para manter a mesma escala nas variáveis utilizadas). É importante considerar que o modelo de OHLSON não recomenda um tipo especial de modelo contábil ou mesmo de práticas contábeis especificas. Assim, é fundamental que o valor do patrimônio por ação seja aquele publicado e advindo da contabilidade financeira empregada no cenário em questão (legislação societária no caso brasileiro). Assim para as finalidades deste trabalho é utilizado o patrimônio legal e não o ajustado ${ }^{52}$. Uma questão extremamente relevante para este trabalho é o cálculo dos resultados anormais. Neste trabalho, utilizou-se o modelo proposto por BERNARD e mais utilizado na literatura do assunto (BROMWICH, 2000). Dessa forma, resultado anormal é definido da seguinte forma:

$$
A b_{i j}=R C_{i j}-\left(B v_{i j-1}^{\star} R f_{j}\right)
$$

Onde:

$$
\begin{aligned}
A b_{i j}= & \text { Resultado contábil anormal por ação para a empresa } i \text { no ano } j . \\
R C_{i j}= & \text { resultado contábil por ação de acordo com os principios geralmente aceitos } \\
& \text { (societário) para a empresa i no ano } j .
\end{aligned}
$$

\footnotetext{
${ }^{31}$ Conforme amplamente reportado na literatura em contabilidade financeira, o desconts a valor prevente ders valores dos resultados anormais não altera dos resultados encontrados, esse resultadu é explicadrs claramente em MAYDEW (1983).

${ }^{2}$ A comparaçăo entre o património legal e o ajustado depende da consideraçăa ou năo de inflaçăo nas

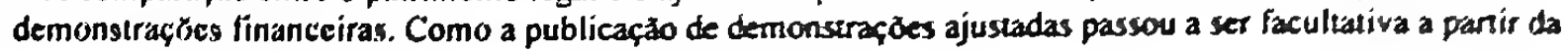


$B v_{i j-1}=$ patrimônio legal por ação para a empresa $i$ no ano $j$.

$R f_{j}=$ taxa de juros livre de risco no ano $j$.

Assim, vê-se que, conforme determinado no modelo de OHLSON, os resultados contábeis anormais são calculados pela subtração do produto da taxa de juros livre de risco do período pelo patrimônio do periodo anterior menos o resultado contábil do periodo em questão. Este conceito de resultado anormal não é o mesmo de residual income tradicionalmente utilizado na literatura. A taxa de juros livre de risco é utilizada nesse modelo ao invés do custo de capital da empresa utilizado em modelos de residual income. Neste trabalho a taxa livre de juros utilizada é a poupança acumulada anual. Essa taxa foi a escolhida conforme comenta SECURATO (1996:128):

"Na economia brasileira poderíamos considerar como risco zero as cadernetas de poupança ou os titulos federais do tipo: BBC (Bônus do Banco Central), NBC (Notas do Banco Central), LFT (Letras Financeiras do Tesouro), e outros, visto que, em cada ocasiāo, temos um tipo de titulo, como representativo do risco zero."

Outras taxas foram testadas (Taxa Acumulada dos Certificados de Depósito Interbancário de um dia) sem alteração nos resultados das especificaçōes realizadas. Essa similaridade dos resultados com diferentes taxas está de acordo com o apresentado na literatura (HORTON, 2000:27). Geralmente, a utilização de diferentes valores para o cálculo do resultado anormal não altera o resultado final da análise com era de se esperar. $O$ conteúdo informativo capturado pelas regressōes (resultado contábil e patrimônio) não é alterado pela transformação linear (monotônica) imposta pela multiplicação pela taxa uma vez que todos os números são multiplicados pelo mesmo valor. 
Um aspecto que merece atenção à parte é a questão do número de periodos utilizados para a os resultados anormais. A utilização de 4 anos reflete o entendimento da literatura neste assunto (BERNARD, 1995, BROMWHICH, 2000) de que resultados anormais năo duram muitos periodos devido à presença de competição que acaba por fazer com que este número tenda a zero no decorrer dos periodos. Outro ponto de vista, proposto por FOSTER (1986:444) sob o título de Myopic Hypothesis sugere que:

"There is a significant association between (a) one-year-ahead (FY1) earnings forecast errors (revisions) and (b) security returns in the period up to and including the month of the actual FY1 earnings are announced."

Assim, as evidências advindas dos estudos empiricos demonstram que existe uma fixaçāo dos investidores em termos de informaçōes de curto prazo. Esses resultados, favoráveis a hipótese da fixaçăo funcional, sugerem que a utilização de mais de quatro periodos não acrescenta relevãncia ao trabalho e pode inviabilizar muitas investigações empiricas ${ }^{53}$.

Para testar a relevância dos dividendos, o seguinte modelo é proposto também de acordo com BERNARD (1995):

$$
\mathbf{P}^{54}{ }_{i j}=\gamma_{0}+\gamma_{1} \operatorname{Div}_{i j+1}+\gamma_{2} \operatorname{Div}_{i j+2}+\gamma_{3} \operatorname{Div}_{i j+3}+\gamma_{4} \operatorname{Div}_{i j+4}+\varepsilon_{i j}
$$

Onde:

Div $_{\mathbf{i j}}=$ dividendo por ação da empresa $i$ no periodo $j$.

Assim, verifica-se, para o periodo de 4 anos, a relevância do valor presente dos dividendos futuros descontados para a avaliação do preço das empresas

comparar qual dos dois números é mais relevante. Este aspecto foge ao escopo desta tese.

${ }^{33}$ Este é o caso deste trabalho que não seria possivel com a utilização de um número superior de períodos.

${ }^{54}$ Nota-se que está tratando-se de preço e năo de um conceito mais abstrato de valor. 
relacionadas. Com essa estrutura a primeira regressão foi especificada para $\circ$ ano de 1995. Assim tem-se:

$$
\text { (1) } P^{55}{ }_{i 95}=\beta_{0}+\beta_{1} B V_{i 95}+\beta_{2} A b_{i 96}+\beta_{3} A b_{i 97}+\beta_{4} A b_{i 98}+\beta_{5} A b_{i 99}+\varepsilon_{i 95}
$$

Para testar a hipótese de que os investidores concentram-se de forma miope nos resultados de um único período a seguinte regressão é feita:

$$
\text { (2) } P_{i 95}=\phi_{0}+\phi_{1} B V_{i 95}+\phi_{2} A b_{i 96}+\mu_{i 95}
$$

Assim, pode-se verificar a importância relativa dos resultados anormais em relação ao preço negociado. Dando continuidade ao teste da hipótese central deste caso, avalia-se o poder explicativo dos dividendos no mesmo periodo considerado:

$$
\text { (3) } P_{i 95}=\gamma_{0}+\gamma_{1} \operatorname{Div}_{i 96}+\gamma_{2} \operatorname{Div}_{i 97}+\gamma_{3} \operatorname{Div}_{i 98}+\gamma_{4} \operatorname{Div}_{i 99}+\varepsilon_{i}
$$

Da mesma forma que na equação 2 avalia-se a hipótese que os investidores valorizam demasiadamente os dividendos no curto prazo:

$$
\text { (4) } P_{i 95}=\varphi_{0}+\varphi_{1} \operatorname{Div}_{i 96}+\varepsilon_{i}
$$

Dando continuidade aos testes, as regressōes foram realizadas para preços tomados em periodos diferentes com número cada vez menor de variáveis independentes. $O$ intuito desse conjunto de testes é verificar se o comportamento das variáveis altera-se com o passar do tempo e se a redução do número de variáveis independentes, mais concentradas no curto prazo, altera o poder explicativo das regressōes. Tem-se assim, na avaliação baseada em números contábeis, para os preços de 1996:

\footnotetext{
ss Verifica-se que a estimação é feita com base em valores reais e não estimados. A estimação pelo método GMM (Generalized Method of Moments) conduz aos mesmos resultados
} 
(5) $P_{i 96}={ }_{96} \beta_{0}+{ }_{96} \beta_{1} B V_{196}+{ }_{96} \beta_{2} A b_{i 97}+{ }_{96} \beta_{3} A b_{i 98}+{ }_{96} \beta_{4} A b_{i 99}+\varepsilon_{i}$

Para 1997:

(6) $P_{i 97}={ }_{97} \beta_{0}+{ }_{97} \beta_{1} B V_{i 97}+{ }_{97} \beta_{2} A b_{i 98}+{ }_{97} \beta_{3} A b_{i 99}+\varepsilon_{i}$

E, finalmente, para 1998:

(7) $P_{i 98}={ }_{98} \beta_{0}+{ }_{98} \beta_{1} B V_{i 98}+{ }_{98} \beta_{2} A b_{i 99}+\varepsilon_{i}$

O mesmo processo é repetido para o modelo de avaliação baseado nos dividendos para os mesmos periodos considerados acima. Assim, para 1996:

(8) $P_{i 96}={ }_{96} \gamma_{0}+{ }_{96} \gamma_{1} \operatorname{Div}_{i 97}+{ }_{96} \gamma_{2} \operatorname{Div}_{i 98}+{ }_{96} \gamma_{3} \operatorname{Div}_{i 99}+\varepsilon_{i}$

Para 1997:

(9) $P_{i 97}={ }_{97} \gamma_{0}+{ }_{97} \gamma_{1}$ Div $_{i 98}+{ }_{97} \gamma_{2}$ Div $_{\text {i99 }}+\varepsilon_{1}$

E conclui-se para 1998:

(10) $P_{i 98}={ }_{98} \gamma_{0}+{ }_{99} \gamma_{1}$ Div $_{i 99}+\varepsilon_{i}$

A análise conjunta dessas dez regressōes tem como objetivo a avaliação da primeira hipótese do trabalho $\left(H_{0 \Omega}\right)$. Essa hipótese não será avaliada com base nos coeficientes ou poder explicativo de uma só regressão. Tais especificaçōes serão analisadas em conjunto para que uma conclusão ampla possa ser obtida. 


\subsection{Poder Explicativo das Variáveis Contábeis}

A segunda hipótese do trabalho refere-se ao poder explicativo das variáveis contábeis (lucro e patrimônio especificamente) em relação ao preço corrente das ações da empresa. Assim:

\section{$H_{0 b}$ : preços correntes podem ser explicados por variáveis contábeis (lucro e patrimônio) com coeficientes estatisticamente significantes.}

Para testar tal assertiva é utilizado a modelagem proposta por COLLINS et all (1997) que é baseada diretamente no modelo de OHLSON. No entanto, essa abordagem é centrada na perspectiva da informação no sentido de avaliar qual a contribuição da contabilidade para explicar os preços de mercado correntes. Assim, tem-se a seguinte especificação geral:

$$
P_{i A j}={ }_{95} \omega_{0}+{ }_{95} \omega_{1} B V_{i j}+{ }_{95} \omega_{2} L u c_{i j}+\varepsilon_{i 95}
$$

Onde:

$\mathbf{P}_{\mathrm{i} A \mathrm{j}}=$ preço das açōes da empresa $i 4$ meses (Abril no caso brasileiro) após o final do exercicio social $j$.

$\mathrm{BV}_{\mathrm{ij}}=$ valor do patrimônio legal por ação da empresa $i$ no final do exercicio social j.

$\operatorname{Luc}_{\mathrm{ij}}=$ valor do lucro liquido por ação da empresa $i$ no final do periodo $j$

$\varepsilon_{i 95}=$ termo de erro da regressão.

Dessa forma, tem-se a seguinte regressão para o ano de 1995: 


$$
\text { (11) } P_{\mathrm{iA96}}={ }_{95} \omega_{0}+{ }_{95} \omega_{1} \mathrm{BV}_{195}+{ }_{95} \omega_{2} \mathrm{LuC}_{\mathrm{ig5}}+\varepsilon_{\mathrm{ig5}}
$$

Conforme proposto por COLLINS et all $(1997)^{56}$, a regressão é repetida usando como variável independente somente o valor do patrimônio para verificar qual a influência desse item particularmente. Segundo esses autores a relevância do lucro e do patrimônio competem, sendo que diversos fatores podem influenciar a maior relevância de um item ou de outro. De forma geral, a relevância do patrimônio é maior em situaçōes nas quais o risco individual (graus de liquidez, etc.) e geral (risco sistêmico, etc.) aumenta. O lucro perde relevância em paises com modelos contábeis menos voltados para o investidor, extremamente regulamentados e com mecanismos de governança corporativa considerados fracos. Essa questão será tratada de forma detalhada na análise dos resultados.

$$
\text { (11a) } P_{\text {iA96 }}={ }_{95} \omega_{0 a}+{ }_{95} \omega_{1 a} B V_{i 95}+\varepsilon_{i 95}
$$

Repetindo o mesmo processo para o ano de 1996:

$$
\text { (12) } P_{\mathrm{iA97}}={ }_{96} \omega_{0}+{ }_{96} \omega_{1} \mathrm{BV}_{\mathrm{ig6}}+{ }_{96} \omega_{2} \mathrm{LuC}_{\mathrm{ig6}}+\varepsilon_{\mathrm{ig6}}
$$

$$
\text { (12a) } P_{i A 97}={ }_{96} \omega_{0 a}+{ }_{96} \omega_{1 a} B V_{i 96}+\varepsilon_{i 96}
$$

Para o ano de 1997, tem-se:

$$
\begin{aligned}
& \text { (13) } P_{\mathrm{IA98}}={ }_{97} \omega_{0}+{ }_{97} \omega_{1} B V_{i 97}+{ }_{97} \omega_{2} L_{u C_{i 97}}+\varepsilon_{i 97} \\
& \text { (13a) } P_{\text {iA98 }}={ }_{97} \omega_{0 a}+{ }_{97} \omega_{13} B V_{i 97}+\varepsilon_{i 97}
\end{aligned}
$$

Para 1998: 
(14) $P_{\text {iA99 }}={ }_{98} \omega_{0}+{ }_{98} \omega_{1} B V_{i 98}+{ }_{98} \omega_{2} L_{u C} C_{98}+\varepsilon_{998}$

(14a) $P_{i A 99}={ }_{98} \omega_{0 a}+{ }_{98} \omega_{1 \mathrm{a}} B V_{198}+\varepsilon_{i 98}$

E, finalmente para 1999:

(15) $\mathrm{P}_{\mathrm{iA2000}}={ }_{99} \omega_{0}+{ }_{99} \omega_{1} \mathrm{BV}_{\mathrm{igg}}+{ }_{99} \omega_{2} \mathrm{LuC}_{\mathrm{igg}}+\varepsilon_{\mathrm{ig9}}$

(15a) $P_{\mathrm{iA2000}}={ }_{99} \omega_{0 \mathrm{a}}+{ }_{99} \omega_{1 \mathrm{a}} \mathrm{B} \mathrm{V}_{\mathrm{ig}}+\varepsilon_{\mathrm{ig}}$

Da mesma forma que no item anterior, a hipótese geral será analisada de acordo com os resultados encontrados nas equaçōes apresentadas acima. A conclusão geral não será baseada no resultado de nenhuma equação em particular, mas sim no resultado do conjunto de regressōes estimadas. Acredita-se que, devido ao horizonte de tempo considerado, os resultados serão mais representativos da realidade brasileira.

\subsection{Reconhecimento Assimétrico e Conservadorismo}

O conservadorismo é uma das caracteristicas mais marcantes do modelo de reconhecimento contábil. A idéia geral é a de que o reconhecimento assimétrico, ativos $e$ receitas subestimados $e$ passivos e despesas superestimados, produz demonstrações mais confiáveis, atendendo aos interesses dos usuários. A partir do trabalho de BASU (1997) o reconhecimento assimétrico ganhou outra dimensão ao ser relacionado com a própria capacidade do resultado contábil reconhecer o resultado econômico. Segundo BASU (1997:3)

"I interpret conservatism as resulting in earnings reflecting 'bad news' more quickly than 'good news'. This interpretation implies systematic differences between bad news and good news periods in the 
timeliness and persistence of earnings. Using firms's sotck returns to measure news, the contemporaneous sensitivity of earnings to negative returns is two to six times that of earnings to positive returns. $I$ also predict and find that negative earnings changes are less persistent than positive earnings changes. Earnings response coeficients (ERCs) are higher for positive earnings changes than for negative earnings changes, consistent with this asymetric persistence."

Assim, o reconhecimento contábil do comportamento do resultado econômico e a assimetria desse reconhecimento constituem-se em propriedades importantes do lucro contábil que podem ser testados. Dessa forma, tem-se a hipótese fundamental desta seção:

\section{$H_{0 c}$ : o resultado contábil incorpora significativamente o resultado econômico.}

Para o teste dessa hipótese será a utilizada a especificação proposta por BASU (1997) e utilizada novamente por BALL et all (2000):

$$
\operatorname{Luc}_{i j}=\jmath_{j} \psi_{0}+{ }_{j} \psi_{1} D_{i j}+{ }_{j} \psi_{2} R E_{i j}+{ }_{j} \psi_{3} D_{j} R E_{i j}+\varepsilon_{i j}
$$

Onde:

$L_{u c} c_{i j}=$ lucro contábil (legal ou societário) da empresa $i$ no ano $j$ por ação.

$D_{i j}=$ variável dummy que assume o valor de 1 quando o resultado econômico é negativo e zero nos demais casos.

$R E_{i j}=$ resultado econômico da empresa $i$ no ano $j$. 
$\varepsilon_{i j}=$ termo de erro da regressão

Assim, na regressão acima, pode-se analisar se o resultado contábil incorpora significativamente o resultado econômico (significância do coeficiente $\left.j \psi_{2}\right)$. Essa especificação é extremamente importante pois permite a avaliação empirica de uma das mais relevantes caracteristicas qualitativas da informação contábil: a oportunidade (timeliness) da informação. Como comentado anteriormente, alguns autores como BALL et all (2000) e BUSHMAN et all (2000), relacionam tais resultados com os mecanismos de governança corporativa em prática nas empresas. A idéia geral é que modelos de governança mais voltados à evidenciação de informações em mercados de capitais mais ativos irão demandar informaçōes contábeis mais oportunas e que os citados coeficientes serão mais significativos do que em modelos de governança menos voltados ao investidor. Os resultados gerais de BALL et all (2000) confirmam essa expectativa. Por outro lado os mecanismos de governança tendem a responder com controles mais restritos em empresas para as quais o lucro contábil não fornece estimativas confiáveis do resultado econômico.

Os coeficientes $j \psi_{1}$ e $j \psi_{3}$ referem-se à assimetria no processo de reconhecimento do resultado econômico pelo resultado contábil. O coeficiente j $\psi_{1}$ refere-se ao aumento ou redução do poder de explicação da regressão na presença de resultados negativos. O coeficiente $j \psi_{3}$ deve ser maior do que $j \psi_{2}$ (bem como estatisticamente mais significativo) se o resultado contábil reconhece mais significativamente os resultados negativos do que os resultados positivos e negativos em conjunto. Conforme visto anteriormente, a análise desses pontos será feita levando-se em consideração o conjunto de regressōes apresentados abaixo e não somente um único ano.

Tem assim para 1996:

(16) $L u c_{i 96}={ }_{96} \psi_{0}+{ }_{96} \psi_{1} D_{96 i}+{ }_{96} \psi_{2} R E_{i 96}+{ }_{96} \psi_{3} D_{96} R E_{i 96}+\varepsilon_{i 96}$ 
Da mesma forma para 1997:

(17) $L_{u c_{i 97}}={ }_{97} \psi_{0}+{ }_{97} \psi_{1} D_{971}+{ }_{97} \psi_{2} R E_{i 97}+{ }_{97} \psi_{3} D_{97} R E_{i 97}+\varepsilon_{i 96}$

Para 1998:

(18) $\mathrm{LuC}_{i 98}={ }_{98} \psi_{0}+{ }_{98} \psi_{1} \mathrm{D}_{98 \mathrm{i}}+{ }_{98} \psi_{2} R \mathrm{E}_{\mathrm{ig8}}+{ }_{98} \psi_{3} \mathrm{D}_{98} R E_{i 98}+\varepsilon_{i 98}$

E finalmente para 1999:

$(19) L u c_{i g 9}={ }_{99} \psi_{0}+{ }_{99} \psi_{1} D_{99 i}+{ }_{99} \psi_{2} R E_{i g 9}+{ }_{99} \psi_{3} D_{9 g} R E_{i g 9}+\varepsilon_{i g 9}$

Espera-se que os resultados encontrados nesse conjunto de especificações possam fornecer uma visão clara do processo de incorporação do resultado econômico pelo resultado contábil pelas empresas selecionadas dentro do período considerado.

\subsection{Resultados Esperados}

Com base nos resultados apresentados na literatura e nas observaçōes apresentadas sobre a realidade contábil e financeira no Brasil, algumas expectativas podem ser construidas a respeito dos resultados empiricos. É importante ressaltar que neste trabalho não se está tentando provar ou reforçar uma ou outra característica dos dados e modelos apresentados. Neste trabalho procura-se uma descrição clara e objetiva da realidade sob análise sem a preocupação com a direção dos resultados encontrados. As expectativas aqui apresentadas são resultado da reflexão sobre a realidade brasileira e não representam, de forma nenhuma, tentativas do autor de provar ou refutar determinada visão. 
De uma forma geral, espera-se que o conjunto de informaçōes emanado pela contabilidade no Brasil não seja especialmente relevante para explicar o comportamento de preços. Segundo a literatura tradicional, vários fatores podem contribuir para a perda de relevância da contabilidade para explicar o comportamento dos preços. Entre eles:

- Excessiva regulamentação da contabilidade financeira.

- Mercado de capitais concentrado com poucas ações em controle público.

- Reduzido papel da profissão na formação das normas contábeis.

- Elevada influência da legislação fiscal na contabilidade financeira.

Esses fatores são presentes, em maior ou menor grau, no Brasil. Levando a expectativa apresentada acima. No entanto, como enfatizado desde as primeiras palavras deste trabalho, essas expectativas estão baseadas na literatura e nos resultados baseados em trabalhos realizados principalmente em mercados desenvolvidos como o norte-americano e o inglês. Muitos aspectos que ainda não foram considerados podem alterar os resultados esperados. Entre eles:

- Ambiente informativo menos rico: entende-se que em mercados emergentes, como o Brasil, o volume de informações à disposição dos investidores seja menor do que em mercados mais desenvolvidos. Assim a 'competição' seria menor, o que aumentaria o conteúdo informativo da contabilidade em relação ao conjunto restante.

- Diferenças no papel da contabilidade dentro da estrutura legal: os números contábeis possuem papel muito importante no Brasil nos casos de liquidação judicial e outros processos de concordata e falência. Esse 
papel pode aumentar a relevância do patrimônio, principalmente, nas especificações realizadas.

- Grau de Desenvolvimento do Mercado: as expectativas apresentadas assumem que os mercados emergentes em geral, e o brasileiro em particular, são menos desenvolvidos em termos de fluxo de informaçōes do que os mercados mais desenvolvidos. Essa premissa pode simplesmente ser falsa para o mercado brasileiro. Mecanismos informais e não analisados na literatura tradicional podem desempenhar um papel relevante no Brasil.

\subsubsection{Lucros e Dividendos}

Em relação à primeira hipótese do trabalho espera-se que o lucro contábil seja menos relevante do que os dividendos pelas razōes apresentadas acima. Espera-se também que haja um certo viés em termos de excessiva importância dos números mais próximos em relação aos relativos ao futuro mais distante, tanto para o lucro contábil como para os dividendos. Essa relativa miopia (fixação funcional no curto prazo) deve-se a elevada instabilidade do mercado brasileiro que naturalmente prejudica projeçōes e análises de longo prazo. Espera-se também que o patrimônio tenha um papel importante nessas especificaçōes. $\dot{E}$ importante comparar os resultados encontrados (em termos de $\mathrm{R}^{2}$ ) com àqueles reportados na literatura para mercados mais desenvolvidos: 0.68 para o modelo contábil e 0,29 para os dividendos de acordo com BERNARD (1995: 738).

\subsubsection{Poder Explicativo dos Números Contábeis}

Novamente, de acordo com a literatura tradicional, não se espera que os resultados apresentados pela contabilidade brasileira sejam importantes para explicar os preços dentro dessa especificação. Espera-se que 0 valor de 
patrimônio seja mais relevante do que 0 relativo ao lucro pelas razões apresentadas acima.

\subsubsection{Reconhecimento Assimétrico e Conservadorismo}

De forma consistente com os comentários acima, nāo se espera que o resultado contábil brasileiro incorpore de forma oportuna o resultado econômico (timeliness). Similarmente, nāo é esperado que haja incorporaçāo assimétrica significativa na amostra analisada. Não existem motivos aparentes para se acreditar que a contabilidade brasileira seja especialmente conservadora. 


\section{EVIDÊNCIAS EMPIRICAS}

Este capitulo apresenta os resultados dos testes relacionados no capitulo anterior bem como as principais estatísticas necessárias à obtenção das conclusōes do trabalho. Inicialmente a fonte dos dados utilizados bem como os critérios aplicados para a seleção da amostra são apresentados. Essa seção possui importância especial, uma vez que os resultados encontrados em qualquer trabalho empirico são fortemente influenciados pelos critérios de seleção da amostra. Em seguida sāo apresentados os resultados das regressōes enumeradas no capitulo anterior divididas em três seções: (i) lucros e dividendos, (ii) poder explanatório das variáveis contábeis e (iii) reconhecimento e conservadorismo.

\subsection{Seleção da Amostra e Estatísticas Descritivas}

Os dados foram coletados do banco de dados ECONOMATICA. Foram coletadas informações referentes ao período de Dezembro de 1995 até Abril de 2000, dependendo do item. Este periodo foi escolhido devido a relativa disponibilidade de dados (a utilização de periodos anteriores reduziria significativamente o tamanho da amostra). Adicionalmente, apesar desse aspecto não estar relacionado aos objetivos do trabalho, esse periodo corresponde à relativa estabilidade econômica advinda do Plano Real o que favorece a comparação dos resultados. Foram eliminadas as empresas para as quais não existem dados disponiveis para qualquer um dos periodos ou variáveis estudadas resultando em 184 títulos incluindo açōes preferenciais e ordinárias; os dados primários são apresentados no apêndice do trabalho. No que se refere ao tamanho da amostra em relação à população total de empresas negociadas na BOVESPA cabe lembrar as observações do artigo clássico de SAM PELTZMAN, 
publicado em STIGLER (p.3-84, 1988) a respeito das limitações do trabalho empírico:

"...government everywhere in the developed world have moved from a sometimes trivial to a now uniformly considerable role in shaping national expenditures. My task will be to try to explain this growth and size. To do so, I am going to equate government's role in economic life with the size of its budget. This is obviously wrong since many government activities (for example, statutes and administrative rules) redirect resources just as surely as taxation and spending, but the available data leave no other choice."

Esse exemplo clássico mostra que na realização de trabalhos empiricos algumas premissas precisam ser estabelecidas para que o trabalho possa ser realizado. O purismo e termos da obtenção dos dados leva a impossibilidade de realização do trabalho.

É relevante ressaltar a não utilização de corte na amostra utilizada em relação aos quartis superiores e inferiores. Optou-se por trabalhar com a amostra em sua forma integral para que não sejam perdidas informaçōes. $A$ tradicional eliminação dos $2,5 \%$ superiores e inferiores não foi realizada. Acredita-se que os resultados obtidos serão mais significativos e robustos com essa medida. A eventual eliminação dessas observações reduziria a variância da amostra aumentando as chances de aceitação das hipóteses utilizadas no trabalho. Dessa forma, a utilização da amostra em sua forma "bruta" aumenta as chances de rejeição das hipóteses utilizadas, o que é perfeitamente aceitável do ponto de vista estatístico uma vez que torna o experimento mais robusto. No entanto, cabe ressaltar que os referidos testes foram realizados com resultados similares aos encontrados com os dados na forma bruta, como é tradicional na literatura (HORTON, 2000). Alguma controvérsia tem surgido em relação ao tratamento 
dado aos valores extremos (outliers) em trabalhos empiricos. FOSTER (1986:100101) comenta da seguinte forma:

"The alternatives available to an analyst when faced with extreme observations (not arising from recording errors) include

1. Deleting the extreme observation on the grounds that it represents a "true outlier";

2. Retaining the extreme observation on the grounds that it represents an extreme state of the undelying characteristic;

3. Making adjustments for the economic or accounting factors believed to cause the extreme observation, for example, by imputing the interest payments associated with "off-balance-sheet" financing;

4. "Winsorizing" the sample, for example, changing the value of extreme observation to the value of the nearest observation no viewed as "suspect";

5. "Trimming" the sample by deleting the top $N$ and the bottom $N$ observations

These alternatives recognize that the causes of extreme values are varied and that a systematci consideration of computation, accounting, economic, and structural change factors facilitates a more reasoned judgement as to their handling in financial statement applications." 
Dessa forma, neste trabalho adota-se a opção No 2 apresentada acima, com o intuito de incrementar o conteúdo informativo dos resultados.

Um aspecto que merece destaque especial é a utilização ou não de dados ajustado pela inflação local. Este aspecto não é relevante para a realização do trabalho. Não estão sendo feitas recomendações normativas acerca de qual é o sistema contábil que deve ser utilizado por analistas e investidores. Neste trabalho são utilizadas as informações publicadas (isto é, aquelas que estão disponiveis para todos os investidores dentro da amostra selecionada) da forma especificada pela legislação. Assim. os dados de Dezembro de 1995 estão dentro do Modelo da Correção Monetária Integral (CMI) enquanto que nos anos seguintes esses estão preparados de acordo com a legislação societária. Novamente, é importante ressaltar que o que se está analisando é o conteúdo informativo das informaçōes disponiveis para os investidores da forma que estas são normalmente produzidas, sem filtros adicionais. Pode-se argumentar que está-se comparando números diferentes devido à utilização da CMI pelas empresas em 1995. Esse aspecto não é relevante para o trabalho. A avaliação de qual modelo produz informaçōes mais relevantes (CMI ou legislação societária) não está dentro dos objetivos deste trabalho. Pode-se argumentar que muitas empresas publicaram a partir de 1996, voluntariamente, informações produzidas de acordo com o método da CMI. No entanto, essa ação é voluntária e não está relacionada com todas as empresas da amostra. Apesar de interessante, a questão do impacto da CMI na relevância das demonstrações publicadas no Brasil não será analisada neste trabalho. As principais estatísticas descritivas estão apresentadas na tabela abaixo.

Tabela 5.1 - Estatísticas Descritivas para a Amostra I

\begin{tabular}{|c|c|c|c|c|c|}
\hline Variável $^{\text {57 }}$ & Média & Desvio Padrão & Mediana & Máximo & Mínimo \\
\hline Preço Dez 1995 & 1,02 & 4,26 & 0,04 & 47,19 & 0,0000132 \\
\hline Preço Dez 1996 & 1,21 & 5,30 & 0,06 & 64,25 & 0,0000100 \\
\hline Preço Dez. 1997 & 1,33 & 6,53 & 0,05 & 82,40 & 0,0000189 \\
\hline
\end{tabular}

${ }^{37}$ Dados apresentados por ação em moeda da época. 


\begin{tabular}{|c|c|c|c|c|c|}
\hline Preço Dez 1998 & $0, \overline{88}$ & 3,48 & 0,03 & 40,26 & 0.0000095 \\
\hline Preço Dex. 1999 & 1,97 & 7,19 & 0.09 & 68.20 & 0.0000300 \\
\hline Preço Abril 1996 & 1,13 & 4,72 & 0.05 & 55,17 & 0.0000150 \\
\hline Preço Abril 1997 & 1.54 & 7,16 & 0,07 & 89.27 & 0,0000229 \\
\hline Preço Abril 1998 & 1,46 & 7,18 & 0.07 & 90,35 & 0,0000207 \\
\hline Preço Abril 1999 & 1,19 & 4,81 & 0,05 & 51,92 & 0,0000095 \\
\hline Preço Abril 2000 & 1,90 & 6,86 & 0.08 & 68,00 & 0.0000300 \\
\hline Patrimônio Dez 1995 & 2,03 & 11,12 & 0.14 & 137.80 & $-44,48$ \\
\hline Patrimônio Dez. 1996 & 1.94 & 11.38 & 0,14 & 133.66 & -57.47 \\
\hline Patrimônio Dez 1997 & 1.95 & 11.09 & 0.13 & 140,89 & $-32,54$ \\
\hline Patrimônio Dez 1998 & 2.32 & 11.41 & 0.14 & 147.97 & $-0,0009750$ \\
\hline Patrimônio Dez 1999 & 2.42 & 11,82 & 0.13 & 151,68 & $-0,1591309$ \\
\hline Lucro 1995 & 0,12 & 1,21 & 0.002821 & 15.17 & 4.27 \\
\hline Lucro 1996 & 0,077 & 1.18 & 0.00310 & 6,43 & -12.99 \\
\hline Lucro 1997 & 0,167 & 2,51 & 0,00410 & 24.94 & $-14,24$ \\
\hline Lucro 1998 & 0,553 & 4.94 & 0,0035 & 65,80 & -1.29 \\
\hline Lucro 1999 & 0.165 & 2.75 & 0.00142 & 18,90 & $-28,77$ \\
\hline Lucro Anormal 1996 & -0.27 & 1.41 & $-0,0078$ & 1.52 & -16.86 \\
\hline Lucro Anormal 1997 & -0.14 & 3.10 & $-0,0055$ & 34.67 & -18.33 \\
\hline Lucro Anormal 1998 & 0.26 & 5.27 & -0.00393 & 70.71 & -8.67 \\
\hline Lucro Anormal 1999) & -0.13 & 2.83 & $-0,00091$ & 18.50 & -32.87 \\
\hline Resultado Econômico 1996 & 0.27 & 1.90 & 0.0085 & 23.88 & -3.35 \\
\hline Resultado Econômico 1997 & 0.23 & 2,21 & 0.0021 & 25.84 & -6.59 \\
\hline Resultado Econômico 1998 & $-0,28$ & 2.24 & -0.004 & 4.29 & .28 .14 \\
\hline Resultado Econômico 1999 & 1,21 & 4,81 & 0.04 & 38.13 & -2.21 \\
\hline Dividendos 1995 & 0.067 & 0.4297 & 0,000666 & 5.60 & $\overline{0}$ \\
\hline Dividendos 1996 & 0.08 & 0,5128 & 0.000794 & 6.83 & 0 \\
\hline Dividendos 1997 & 0.11 & 0,60 & 0.0014 & 7.68 & 0 \\
\hline Dividendos 1998 & 0.17 & 1.08 & 0.0023 & 14.00 & 0 \\
\hline Dividendos 1999 & 0.13 & 0.67 & 0.00132 & 8,20 & 0 \\
\hline Patrimônio/Mercado 1995 (BTM) & 4,24 & 5,35 & 2,92 & 39,98 & -13.88 \\
\hline Patrimônio/Mercado 1996 (BTM & 2,94 & 4,10 & 1,95 & 23.39 & -27.89 \\
\hline Patrinônio/Mercado 1997 (B'TMI & 2.60 & 3.68 & 1,78 & 17,06 & -18.15 \\
\hline Pâtrimônio/Mlercado 1998 (BTMI & 3.29 & 9,33 & 2.66 & 29.61 & -102.79 \\
\hline Patrinônio/Mlercado 1999 (B'TM & 1.47 & 2.11 & 1.27 & 15.77 & -7.29 \\
\hline
\end{tabular}

Os dados apresentados nessa tabela fornecem algumas informaçōes importantes sobre a realidade brasileira. Inicialmente verifica-se o elevado desvio padrão do preço das ações bem como dos dados de patrimônio e lucro. Verifica- 
se também que o lucro possui desvio padrão superior, em média, àquele dos preços. O valor da razão entre o patrimônio por ação dividido pelo preço por ação (book to market ratio) é superior a 1 (um) em todos os anos analisados chegando a ser superior a 4 em 1995. Esse indicador, de acordo com BEAVER (1998), é um indicador do grau de conservadorismo do modelo contábil em questão sendo, normalmente, inferior à unidade. Segundo esses resultados, o valor do patrimônio no Brasil é superior ao valor de mercado das empresas. Esse aspecto indica que a contabilidade das empresas brasileiras está reconhecendo itens que não o são pelo mercado. É um espécie de conservadorismo às avessas. Esse aspecto é bastante interessante, pois indica um modelo contábil que fere um dos aspectos mais comuns nas estruturas conceituais básicas da contabilidade analisadas neste trabalho. No Brasil, o conservadorismo é considerado como uma convenção dentro da estrutura conceitual do IPECAFI/IBRACON ${ }^{58}$ e como um princípio dentro da proposta do Conselho Federal de Contabilidade em sua Resolução $\mathrm{N}^{0} 750^{59}$, 1983.

É relevante notar que não se está criticando o modelo contábil adotado pelas empresas brasileiras que está produzindo números superiores àqueles apresentados no mercado. Não se está trabalhando com o conceito de 'melhor' modelo de acordo com esse conceito. É somente importante notar que estes valores não são consistentes com as idéias apresentadas na estrutura conceitual básica da contabilidade brasileira referendada pelo órgão regulador. $A$ análise dos resultados encontrados na seção 5.4 (Reconhecimento e Conservadorismo) esclarecerá melhor essas questões.

\footnotetext{
${ }^{58}$ É de extrema importância notar que a estrutura conceitual básica da contabilidade brasileira desenvolvida pelo IPECAFI/IBRACON é referendada pela Comissão de Valores Mobiliários (CVM) para utilização pelas empresas negociadas em Bolsa de Valores que são objeto deste trabalho.

${ }^{59}$ A interpretação desse resultado deve ser cuidadosa. A reflexāo menos cuidadosa pode levar à conclusão de que a contabilidade brasileira produz números "fracos" excessivamente otimistas. No entanto, a resposta dessa "anomalia" demanda um estudo próprio e a resposta pode estar relacionada com valores de mercado excessivamente baixos advindos do fato que as empresas brasileiras não estão com o controle acionário
} 


\subsection{Lucro vs. Dividendos ${ }^{60}$}

Devido ao grande número de variáveis envolvidas nesta estimação, os resultados estão divididos de acọdo com os grupos analisados. Assim, a tabela 5.2 abaixo apresenta os resultados das regressões (1) e (3) apresentadas no capítulo anterior, bem como as estatísticas t para os coeficientes das regressões bem o como o valor $p$ :

Tabela 5.2 - Regressões (1) e (3)

\begin{tabular}{|c|c|c|c|c|c|c|c|c|c|c|c|c|c|}
\hline & & (I) & $\begin{array}{l}y=\beta \\
\text { (2) } P\end{array}$ & $\begin{array}{l}+\beta_{1} B \\
{ }_{5}=\gamma_{0}\end{array}$ & $\begin{array}{l}V_{i 95}+ \\
+\gamma_{1} D\end{array}$ & $\begin{array}{l}{ }_{2} A b_{i 96} \\
i 96+\end{array}$ & $\operatorname{Div}_{i 97}$ & $\begin{array}{l}\overline{7+\beta} \\
\gamma_{3} \mathrm{Di}\end{array}$ & $\begin{array}{l}b_{i 98}+ \\
88+\gamma_{4}\end{array}$ & $\begin{array}{l}{ }_{s} A b_{i 99} \\
\gamma_{i 99}+\varepsilon\end{array}$ & & & \\
\hline Variável & $\beta_{0}$ & $\beta_{1}$ & $\beta_{2}$ & $\beta_{3}$ & $\beta_{4}$ & $\overline{\beta_{s}}$ & $\mathrm{R}^{2}$ & $\gamma_{0}$ & $\gamma_{1}$ & $\gamma_{2}$ & $\gamma_{3}$ & $\gamma_{4}$ & $\mathrm{R}^{2}$ \\
\hline $\mathrm{P}_{\mathrm{i} 95}$ & 0,72 & 0,37 & -0.24 & $-0,18$ & 0.54 & 0.31 & 0.93 & 0,36 & 1.52 & $-1,28$ & 1,47 & 3,42 & 0,82 \\
\hline Coef. T & 0,84 & 13,29 & -1.17 & -2.84 & 12,76 & 9.35 & 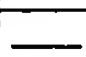 & 2.55 & 1,25 & $-1,33$ & 1,36 & 2.97 & \\
\hline$p$-value & 0.40 & 0,00 & 0,24 & 0,00 & 0,00 & 0.00 & & 0.11 & 0.21 & 0,19 & 0.17 & 0.00 & \\
\hline
\end{tabular}

Esses resultados indicam que o poder explicativo do modelo baseado em dados contábeis é ligeiramente superior ao baseado no valor dos dividendos futuros. Em ambos os casos os interceptos não são significativos dentro do nível de significância de 0,01 . No entanto, os coeficientes dos resultados anormais sāo todos significativos com exceção do resultado anormal de 1996, enquanto que os valores dos dividendos são todos não significativos com exceção do ano de 1999. Esses resultados são consistentes com a literatura mostrando a superioridade do modelo baseado em dados contábeis sobre o modelo baseado nos dividendos futuros. Para a comparação do poder explicativo dos números contábeis e dos dividendos no curto prazo tem-se os resultados das regressões (2) e (4)

${ }^{60}$ O pagamento obrigatório de dividendos no Brasil deve ser levado em conta na interpretação dos resultados. 
Tabela 5.3-Regressões (2) e (4)

\begin{tabular}{|c|c|c|c|c|c|c|c|}
\hline \multicolumn{8}{|c|}{ (2) $P_{i 95}=\phi_{0}+\phi_{1} B V_{i 95}+\phi_{2} A b_{i 96}+\mu_{i 95}$ e (4) $P_{i 95}=\varphi_{0}+\varphi_{1} D_{i v_{i 96}}+\varepsilon_{i}$} \\
\hline Variáveis & $\phi_{0}$ & $\phi_{1}$ & $\phi_{2}$ & $\mathrm{R}^{2}$ & $\varphi_{0}$ & $\varphi_{1}$ & $\mathrm{R}^{2}$ \\
\hline$P_{i g 5}$ & 0,25 & 0,17 & $-1,60$ & 0.87 & 0,45 & 7.18 & 0,75 \\
\hline Coef. T & 2,10 & 10.37 & $-11,99$ & & 2,78 & 23.17 & \\
\hline$p$-value & 0.04 & 0,00 & 0,00 & & 0,01 & 0,00 & \\
\hline
\end{tabular}

Verifica-se, novamente a superioridade do modelo contábil sobre o modelo baseados em dividendos futuros. No entanto, a observação mais relevante acerca dessas regressões é que o poder explicativo de ambas é bastante alto utilizandose somente dados de um período futuro; de forma complementar, as duas regressões possuem coeficientes que são estatisticamente significativos dentro dos limites estabelecidos. Esses resultados favorecem a hipótese da fixação funcional mostrando que, no Brasil, os investidores parecem estar focados nos resultados de curto prazo ao invés da consideração de periodos mais amplos.

De forma similar, tem-se a análise comparativa dos resultados para as regressões 5 e 8 .

Tabela 5.4 - Regressões (5) e (8)

\begin{tabular}{|c|c|c|c|c|c|c|c|c|c|c|c|}
\hline \multicolumn{12}{|c|}{$\begin{array}{l}\text { (5) } \mathrm{P}_{i 96}={ }_{96} \beta_{0}+{ }_{96} \beta_{1} B V_{i 96}+{ }_{96} \beta_{2}{ }^{A} b_{i 97}+{ }_{96} \beta_{3} A b_{i 98}+{ }_{96} \beta_{4}{ }^{A} b_{i 99}+\varepsilon_{i} e \\
\text { (8) } P_{i 96}={ }_{96} \gamma_{0}+{ }_{96} \gamma_{1} D_{i v_{i 97}}+{ }_{96} \gamma_{2} D_{i v_{i 98}}+{ }_{96} \gamma_{3} D_{i v_{i 99}}+\varepsilon_{i}\end{array}$} \\
\hline Variáveis & ${ }_{96} \beta_{0}$ & ${ }_{96} \beta_{1}$ & ${ }_{96} \beta_{2}$ & ${ }_{96} \beta_{3}$ & ${ }_{96} \beta_{4}$ & $\mathrm{R}^{2}$ & $96 \gamma_{0}$ & $96 \gamma_{1}$ & $96 \gamma_{2}$ & $96 \gamma_{3}$ & $\mathrm{R}^{2}$ \\
\hline$P_{1 y 5}$ & 0,04 & 0.56 & 0,17 & 0.63 & 0,38 & 0,97 & 0,37 & 0,67 & 3.25 & 1,71 & 0,90 \\
\hline Coef. $\mathrm{T}$ & 0,51 & 62.99 & 3.38 & 21,95 & $\overline{6,86}$ & - & 2,83 & 0,84 & 3.66 & 1,66 & $\longrightarrow$ \\
\hline p-value & 0.60 & 0,00 & 0.00 & 0.00 & 0,00 & - & 0,01 & 0,40 & 0,00 & 0.10 & - \\
\hline
\end{tabular}

Para as regressões 6 e 9.

Tabela 5.5 - Regressões (6) e (9) 
(6) $P_{i 97}={ }_{97} \beta_{0}+{ }_{97} \beta_{1} B V_{i 97}+{ }_{97} \beta_{2} A b_{i 98}+{ }_{97} \beta_{3} A b_{i 99}+\varepsilon_{i} e$

(9) $\mathrm{P}_{\mathrm{i} 97}={ }_{97} \gamma_{0}+{ }_{97} \gamma_{1} \operatorname{Div}_{\mathrm{i} 98}+{ }_{97} \gamma_{2} \operatorname{Div}_{i 99}+\varepsilon_{\mathrm{i}}$

\begin{tabular}{|c|c|c|c|c|c|c|c|c|c|}
\hline Variáveis & ${ }_{97} \beta_{0}$ & ${ }_{97} \beta_{1}$ & ${ }_{97} \beta_{2}$ & ${ }_{97} \beta_{3}$ & $R^{2}$ & $9 \gamma_{0}$ & ${ }_{97} \gamma_{1}$ & $97 \gamma_{2}$ & $R^{2}$ \\
\hline$P_{i 95}$ & $-0,04$ & 0,63 & 0,60 & 0,17 & 0,98 & 0,34 & 5,72 & 0,17 & 0,93 \\
\hline Coef. $T$ & $-0,50$ & 86,73 & 21,60 & 3,42 & - & 2,57 & 9,19 & 0,17 & - \\
\hline p-value & 0,62 & 0,00 & 0,00 & 0,00 & - & 0,01 & 0,00 & 0,86 & - \\
\hline
\end{tabular}

Novamente, verifica-se o grande poder explicativo dos resultados de curto prazo, tanto para o modelo baseado em valores contábeis como para o baseado em dividendos futuros.

E finalmente, para as regressões 7 e 10.

Tabela 5.6 - Regressões (7) e (10)

\begin{tabular}{|c|c|c|c|c|c|c|c|}
\hline \multicolumn{8}{|c|}{ (7) $P_{i 98}={ }_{98} \beta_{0}+{ }_{98} \beta_{1} B V_{i 98}+{ }_{98} \beta_{2} A b_{i 99}+\varepsilon_{i} e(10) P_{i 98}={ }_{98} \gamma_{0}+{ }_{99} \gamma_{1} D i v_{i 99}+\varepsilon_{i}$} \\
\hline Variáveis & ${ }_{98} \beta_{0}$ & ${ }_{93} \beta_{1}$ & ${ }_{98} \beta_{2}$ & $\mathrm{R}^{2}$ & ${ }_{98} \gamma_{0}$ & $98 \gamma_{1}$ & $\mathrm{R}^{2}$ \\
\hline$P_{i 95}$ & 0,20 & 0,29 & $-0,08$ & 0,93 & 0,27 & 2,67 & 0,84 \\
\hline Coef. $T$ & 3,05 & 47,55 & $-3,079$ & - & 4,79 & 31,63 & - \\
\hline$p$-value & 0,00 & 0,00 & 0,00 & - & 0,01 & 0,00 & - \\
\hline
\end{tabular}

Os resultados acima são consistentes com àqueles apresentados para as regressões 2 e 4 . Novamente verifica-se a superioridade do modelo baseado em resultados contábeis e com elevada fixação nos valores de curto prazo. Aparentemente a hipótese da fixação funcional tem validade para essas variáveis contábeis no Brasil. 


\subsection{Poder Explicativo das Variáveis Contábeis}

Nesta seção serāo apresentados os resultados das equações (11), (12), (13), (14) e (15), bem como para as respectivas regressões relativas somente ao patrimônio como variável independente. Assim, para o ano de 1995.

Tabela 5.7 - Poder Explicativo Var. Contábeis 1995: Regressão (11)

\begin{tabular}{|c|c|c|c|c|}
\hline \multicolumn{5}{|c|}{$\left(1\right.$ I) $\mathrm{P}_{\mathrm{iA} 96}={ }_{95} \omega_{\mathrm{O}}+{ }_{95} \omega_{1} \mathrm{BV}_{\mathrm{i95}}+{ }_{95} \omega_{2} \mathrm{Luc}_{\mathrm{i9s}}+\varepsilon_{\mathrm{i95}}$} \\
\hline Variáveis & ${ }_{95} \omega_{0}$ & ${ }_{95} \omega_{1}$ & ${ }_{95} \omega_{2}$ & $\mathrm{R}^{2}$ \\
\hline $\mathrm{P}_{\mathrm{iA96}}$ & 0,05 & 0,42 & 1,79 & 0,95 \\
\hline Coeficiente $\iota$ & 0,62 & 56,09 & 25,45 & - \\
\hline$p$-value & 0,53 & 0,00 & 0,00 & \\
\hline
\end{tabular}

Os resultados dessa regressão mostram a insignificância estatística do intercepto da regressāo a significância dos valores de patrimônio e lucro com elevado poder explicativo. A próxima especificação testa qual a contribuição do patrimônio individualmente para a composição desse poder explicativo .

Tabela 5.7a - Poder Explicativo Book Value 1995: Regressão (11a)

\begin{tabular}{|c|c|c|c|}
\hline \multicolumn{4}{|c|}{$\left(11^{3}\right) P_{i A 96}={ }_{95} \omega_{D_{2}}+{ }_{95} \omega_{13} B V_{995}+\varepsilon_{i 95}$} \\
\hline Variáveis & ${ }_{95} \omega_{b_{3}}$ & ${ }_{95} \omega_{l_{a}}$ & $\mathrm{R}^{2}$ \\
\hline$\overline{P_{i, 966}}$ & 0,39 & 0,36 & 0.76 \\
\hline Coeficiente $t$ & 2,23 & 23,77 & $\square$ \\
\hline$p$-value & 0,027 & 0,00 & 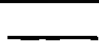 \\
\hline
\end{tabular}

Verifica-se que o patrimônio individualmente explica grande parte do comportamento dos preços com coeficientes estatisticamente significantes.

Para o ano de 1996: 
Tabela 5.8 - Poder Explicativo Var. Contábeis 1996: Regressão (12)

\begin{tabular}{|c|c|c|c|c|}
\hline \multicolumn{5}{|c|}{$(12) \mathrm{P}_{\mathrm{iA97}}={ }_{96} \omega_{0}+{ }_{96} \omega_{1} \mathrm{BV}_{\mathrm{i96}}+{ }_{96} \omega_{2} \mathrm{Luc}_{996}+\varepsilon_{\mathrm{i96}}$} \\
\hline Variáveis & ${ }_{96} \omega_{0}$ & ${ }_{96} \omega_{1}$ & ${ }_{96} \omega_{2}$ & $\mathrm{R}^{2}$ \\
\hline $\mathrm{P}_{\text {iA97 }}$ & 0,21 & 0,84 & $-3,80$ & 0,91 \\
\hline Coeficiente I & 1,36 & 41,09 & $-19,30$ & - \\
\hline$p$-value & 0,18 & 0,00 & 0,00 & - \\
\hline
\end{tabular}

Novamente, verifica-se que o intercepto não é significativo com alto poder explicativo para a composição do lucro e do patrimônio.

Tabela 5.8a - Poder Explicativo Book Value 1996: Regressão (12a)

\begin{tabular}{|c|c|c|c|}
\hline \multicolumn{4}{|c|}{$\left(12^{2}\right) P_{i A 97}={ }_{96} \omega_{0}+{ }_{96} \omega_{13} B V_{i 96}+\varepsilon_{i 96}$} \\
\hline Variáveis & $\left.{ }_{96}(1)\right)_{3}$ & ${ }_{96} \omega_{12}$ & $\mathrm{R}^{2}$ \\
\hline$P_{i A 97}$ & 0.49 & 0,54 & 0.74 \\
\hline Coefíciente 6 & $1, \overline{79}$ & 23,02 & 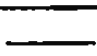 \\
\hline p-value & 0.07 & 0,00 & {[} \\
\hline
\end{tabular}

Os resultados para o ano de 1996 também são consistentes com àqueles apresentados para 1995.

Em 1997:

Tabela 5.9 - Poder Explicativo Var. Contábeis 1997: Regressão (13)

\begin{tabular}{|c|c|c|c|c|}
\hline \multicolumn{5}{|c|}{$(13) \mathrm{P}_{\mathrm{i} \wedge 98}={ }_{97} \omega_{0}+{ }_{97} \omega_{1} \mathrm{BV} \mathrm{V}_{\mathrm{9} 97}+{ }_{97} \omega_{2} \mathrm{Luc}_{\mathrm{i97}}+\varepsilon_{\mathrm{i97}}$} \\
\hline Variáveis & ${ }_{97} \omega_{0}$ & ${ }_{97} \omega_{1}$ & ${ }_{97} \omega_{2}$ & $\mathrm{R}^{2}$ \\
\hline $\mathrm{P}_{\mathrm{iA98}}$ & 0,24 & 0,55 & 0,84 & 0,92 \\
\hline Coeficiente t & 1,59 & 40,33 & 13,79 & - \\
\hline$p$-value & 0,11 & 0,00 & 0,00 & Nāo Determinado \\
\hline
\end{tabular}


Tabela 5.9a - Poder Explicativo Book Value 1997: Regressāo (13a)

\begin{tabular}{|c|c|c|c|}
\hline \multicolumn{4}{|c|}{$(13 \mathrm{a}) \mathrm{P}_{\mathrm{iA98}}={ }_{97} \omega_{0_{2}}+{ }_{97} \omega_{13} \mathrm{BV}_{\mathrm{i97}}+\varepsilon_{997}$} \\
\hline Variáveis & ${ }_{97} \omega_{\mathrm{O}_{3}}$ & ${ }_{97} \omega_{1 \mathrm{a}}$ & $\mathrm{R}^{2}$ \\
\hline $\mathrm{P}_{\mathrm{iA98}}$ & 0,30 & 0,59 & 0,84 \\
\hline Coeficiente $\mathrm{t}$ & 1,41 & 30,93 & - \\
\hline$p$-value & 0,16 & 0,00 & \\
\hline
\end{tabular}

Neste ano o intercepto apresenta-se não significativo.

Da mesma forma, para 1998:

Tabela 5.10 - Poder Explicativo Var. Contábeis 1998: Regressāo (14)

\begin{tabular}{|c|c|c|c|c|}
\hline \multicolumn{5}{|c|}{ (14) $P_{i A 99}={ }_{98} \omega_{0}+{ }_{98} \omega_{1} B V_{i 98}+{ }_{98} \omega_{2} L u c_{i 98}+\varepsilon_{i 98}$} \\
\hline Variáveis & ${ }_{9 s} \omega_{0}$ & ${ }_{9 s} \omega_{1}$ & ${ }_{98} \omega_{2}$ & $\mathrm{R}^{2}$ \\
\hline$\overline{P_{i \lambda 99}}$ & 0,29 & 0.39 & $-0,03$ & 0.85 \\
\hline Coeficiente $!$ & 2.08 & 29,83 & $-0,809$ & $\longrightarrow$ \\
\hline p-value & 0,04 & 0,00 & 0,42 & 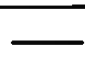 \\
\hline
\end{tabular}

Neste ano a regressão está bem especificada com todos os componentes sendo significativos e também com alto poder explicativo.

Tabela 5.10a - Poder Explicativo Book Value 1998: Regressāo (14a)

\begin{tabular}{|c|c|c|c|}
\hline \multicolumn{4}{|c|}{$(14 \mathrm{a}) \mathrm{P}_{\mathrm{iA} 99}={ }_{98} \omega_{0 \mathrm{a}}+{ }_{98} \omega_{1 \mathrm{1}} \mathrm{BV}_{\mathrm{i98}}+\varepsilon_{\mathrm{i98}}$} \\
\hline Variáveis & ${ }_{98} \omega_{\mathrm{O}_{\mathrm{a}}}$ & ${ }_{98} \omega_{1 \mathrm{a}}$ & $\mathrm{R}^{2}$ \\
\hline $\mathrm{P}_{\mathrm{iA} 99}$ & 0,29 & 0,39 & 0,85 \\
\hline Coefícience $\mathrm{I}$ & 2,06 & 32,03 & - \\
\hline$p$-value & 0,04 & 0,00 & - \\
\hline
\end{tabular}


Verifica-se, no entanto, que o patrimônio continua contribuindo com a maior parte do poder explicativo.

Finalmente para 1999:

Tabela 5.11 - Poder Explicativo Var. Contábeis 1999: Regressão (15)

\begin{tabular}{|c|c|c|c|c|}
\hline \multicolumn{5}{|c|}{ (15) $P_{i_{A} 2000}={ }_{99} \omega_{0}+{ }_{99} \omega_{1} B V_{i 99}+{ }_{99} \omega_{2} L u c_{i 99}+\varepsilon_{i 99}$} \\
\hline Variáveis & ${ }_{99} \omega_{0}$ & ${ }_{99} \omega_{1}$ & ${ }_{99} \omega_{2}$ & $\mathrm{R}^{2}$ \\
\hline$P_{\mathrm{iA} 2000}$ & 0,65 & 0,50 & 0,22 & 0,80 \\
\hline Coeficiente I & 2,84 & 24,71 & 2,47 & 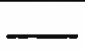 \\
\hline$p$-value & 0,00 & 0,00 & 0,01 & $\ldots$ \\
\hline
\end{tabular}

Como em 1998, a regressāo apresenta todos os coeficientes significativos e com alto poder explicativo, apesar de reduzido em relaçāo aos anos anteriores.

Tabela 5.11a - Poder Explicativo Var. Contábeis 1999: Regressão (15a)

\begin{tabular}{|c|c|c|c|}
\hline \multicolumn{4}{|c|}{$(15 a) P_{i \lambda 2000}={ }_{99}\left(\omega_{j_{2}}+{ }_{0}\right) \omega_{13} B V_{i 99}+\varepsilon_{i 99}$} \\
\hline Variáveis & $90 w_{02}$ & ${ }_{9 g} \omega_{1 \mathrm{a}}$ & $\mathrm{R}^{2}$ \\
\hline$P_{i A 2000}$ & 0,65 & 0.52 & 0.79 \\
\hline Coeficiente & 2.72 & 26,80 & 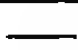 \\
\hline$p$-value & 0,01 & 0.00 & 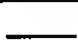 \\
\hline
\end{tabular}

De forma consistente com os anos anteriores o poder explicativo do modelo parece vir quase que somente da variável patrimônio.

\subsection{Reconhecimento Assimétrico e Conservadorismo}

As regressões 16 a 19 referem-se à capacidade do resultado contábil de incorporar o resultado econômico e adicionalmente de refletir a assimetria no reconhecimento desse. Tem-se assim, para o ano de 1996 
Tabela 5.12 - Reconhecimento e Conservadorismo 96:Regressão (16)

\begin{tabular}{|c|c|c|c|c|c|}
\hline \multicolumn{6}{|c|}{ (16) $\mathrm{Luc}_{996}={ }_{96} \psi_{0}+{ }_{96} \Psi_{1} \mathrm{D}_{96 \mathrm{i}}+{ }_{96} \psi_{2} R E_{i 96}+{ }_{96} \Psi_{3} \mathrm{D}_{96} \mathrm{RE}_{\mathrm{i} 96}+\varepsilon_{i 96}$} \\
\hline Variáveis & ${ }_{96} \Psi_{0}$ & ${ }_{96} \Psi_{1}$ & ${ }_{96} \Psi_{2}$ & $96 \Psi_{3}$ & $\mathrm{R}^{2}$ \\
\hline Luc $_{\text {i96 }}$ & 0,079 & $-0,39$ & 0,29 & $-0,49$ & 0.24 \\
\hline Coeficiente $\mathrm{t}$ & 0.845 & $-2,20$ & 6,89 & $-2,09$ & {[} \\
\hline$p$-value & 0,40 & 0,03 & 0,00 & 0,04 & - \\
\hline
\end{tabular}

Os resultados dessa regressão indicam baixo poder explicativo com intercepto não significante. Os valores dos coeficientes para as variáveis dummy, resultado econômico e resultado econômico vezes dummy sāo significativos. Observa-se $O$ valor do coeficiente ${ }_{96} \psi_{3}$ sendo inferior ao valor de $9_{96} \psi_{2}$ demonstrando, claramente, que os resultados negativos não são incorporados mais significativamente do que o resultado de uma forma geral. Esse resultado é consistente com os valores encontrados nas estatísticas descritivas mostrando o baixo conservadorismo dos números contábeis publicados no Brasil.

Para o ano de 1997:

Tabela 5.13 - Reconhecimento e Conservadorismo 97: Regressão (17)

\begin{tabular}{|c|c|c|c|c|c|}
\hline \multicolumn{6}{|c|}{ (17) $\mathrm{Luc}_{997}={ }_{97} \psi_{0}+{ }_{97} \psi_{1} \mathrm{D}_{97 \mathrm{i}}+{ }_{97} \psi_{2} \mathrm{RE}_{i 97}+{ }_{97} \psi_{3} \mathrm{D}_{97} \mathrm{RE}_{\mathrm{i97}}+\varepsilon_{i 96}$} \\
\hline Variáveis & ${ }_{97} \Psi_{0}$ & ${ }_{97} \Psi_{1}$ & ${ }_{97} \Psi ?$ & ${ }_{97} \psi_{3}$ & $\mathrm{R}^{2}$ \\
\hline $\operatorname{Luc}_{i 97}$ & 0,03 & $-0,015$ & 0.77 & 0,33 & 0,50 \\
\hline Coeticiente t & 0,19 & $-0,056$ & 12,11 & 1.50 & 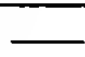 \\
\hline$p$-value & $0, \overline{84}$ & 0,95 & 0,00 & 0,13 & $\ldots$ \\
\hline
\end{tabular}

Nesses resultados, verifica-se um maior poder explicativo sendo ofuscado pela não insignificância estatística do intercepto da regressão. Novamente verificase que o coeficiente ${ }_{97} \psi_{3}$ é menor do que ${ }_{97} \psi_{2}$ levando à mesma conclusāo dos resultados apresentados anteriormente. 
Em 1998:

Tabela 5.14-Reconhecimento e Conservadorismo 98: Regressão (18)

\begin{tabular}{|c|c|c|c|c|c|}
\hline \multicolumn{6}{|c|}{ (18) $\mathrm{Luc}_{998}={ }_{98} \psi_{0}+{ }_{98} \psi_{1} \mathrm{D}_{98 \mathrm{i}}+{ }_{98} \psi_{2} R E_{\mathrm{i98}}+{ }_{98} \psi_{3} \mathrm{D}_{98} R E_{i 98}+\varepsilon_{i 9}$} \\
\hline Variáveis & $98 \psi_{0}$ & ${ }_{98} \psi_{1}$ & $98 \Psi_{2}$ & ${ }_{18} \psi_{3}$ & $\mathrm{R}^{2}$ \\
\hline $\operatorname{Luc}_{i 98}$ & 0,12 & 0,24 & 0,35 & $-0,93$ & 0,07 \\
\hline Coeticiente t & 0,13 & 0.24 & 0.35 & $-0,90$ & - \\
\hline$p$-value & 0,89 & 0,81 & 0,73 & 0,36 & - \\
\hline
\end{tabular}

Os resultados em 1998 são consistentes com àqueles reportados anteriormente.

E para 1999:

Tabela 5.15 - Reconhecimento e Conservadorismo 99: Regressão (19)

\begin{tabular}{|c|c|c|c|c|c|}
\hline \multicolumn{6}{|c|}{ (19) Luc $_{999}={ }_{99} \psi_{0}+{ }_{99} \psi_{1} \mathrm{D}_{99 \mathrm{i}}+{ }_{99} \psi_{2} \mathrm{RE}_{\mathrm{i99}}+{ }_{99} \psi_{3} \mathrm{D}_{99} \mathrm{RE}_{\mathrm{i99}}+\varepsilon_{i 99}$} \\
\hline Variáveis & ${ }_{99} \psi_{0}$ & $99 \Psi_{1}$ & $99 \Psi_{2}$ & ${ }_{99} \psi_{3}$ & $\mathrm{R}^{2}$ \\
\hline Luc $_{i 99)}$ & 0.04 & 0,43 & 0.22 & 8.35 & 0.53 \\
\hline Coeficiente $t$ & 0,28 & 0,87 & 7,48 & 11,14 & ב- \\
\hline p-value & 0,78 & 0,38 & 0,00 & 0,00 & 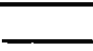 \\
\hline
\end{tabular}

O resultado do ano de 1999 é inconsistente com os apresentados anteriormente. $O$ valor do coeficiente ${ }_{9} \psi_{3}$ mostra-se muito superior a ${ }_{9} \psi_{2}$ demonstrando a incorporação mais significativa dos resultados negativos. Esse resultado começa a fazer sentido com a comparaçāo o valor do indice patrimônio/preço apresentado nas estatísticas descritivas. 


\subsection{Diagnóstico das Regressões Realizadas}

Vários testes foram realizạdos com o intuito de verificar a adequação do método dos mínimos quadrados ordinários para as regressões especificadas. $A$ tabela abaixo apresenta as principais medidas de interesse para o trabalho.

\section{Tabela 5.16 - Diagnósticos das Regressões Realizadas}

\begin{tabular}{|c|c|c|c|c|}
\hline Regressões & Variância & Durbin-Watson & Signiticância D-W & Estatística $F$ \\
\hline Regressão 1 & 1,13 & 1,33 & Autocorr. Positiva & $(0,0000)$ \\
\hline Regressūo 2 & 1,55 & 1,68 & Ausência de Autocorr. & $(0,0000)$ \\
\hline Regressão 3 & 1,81 & 1,65 & Inconclusivo & $(0,0000)$ \\
\hline Regressāo 4 & 2,15 & 1,30 & Autocorr. Positiva & $(0,0000)$ \\
\hline Regressĩo 5 & 0,93 & 1,81 & Ausência de Autocorr. & $(0,0000)$ \\
\hline Regressīo 6 & 0.91 & 2,09 & Ausência de Autocorr. & $(0,0000)$ \\
\hline Regressiāo 7 & 0.89 & 1,71 & Ausência de Autocorr. & $(0,0000)$ \\
\hline Regressão 8 & 1,67 & 1,62 & Inconclusivo & $(0,0000)$ \\
\hline Regressāo 9 & 1,75 & 1,81 & Ausência de Autocorr. & $(0,0000)$ \\
\hline Regressão 10 & 1,36 & 1,96 & Ausência de Autocorr. & $(0,0000)$ \\
\hline Regressĩo II & 1,09 & 1,90 & Ausência de Autocorr. & $(0.0000)$ \\
\hline Regressāo $11^{a}$ & 2,34 & 1.92 & Ausência de Autocorr. & $(0.0000)$ \\
\hline Regressảo 12 & 2.08 & 2,01 & Ausência de Autocorr. & $(0.0000)$ \\
\hline Regrussão 12a & 3,63 & 1,98 & Ausência de Autocorr. & $(0.0000)$ \\
\hline Regressão 13 & 2,01 & 2.00 & Ausência de Autocorr. & $(0.0000)$ \\
\hline Regressijo $13^{2}$ & 2,88 & 2,00 & Ausência de Autocorr. & $(0,0000)$ \\
\hline Regressāo 14 & 1,87 & 1,32 & Autocorr. Positiva & $(0,0000)$ \\
\hline Regressāo $14^{2}$ & 1,87 & $1,3 !$ & Autocorr. Positiva & $(0,0000)$ \\
\hline Regressũo 15 & 3,05 & 1,12 & Autocorr. Positiva & $(0,0000)$ \\
\hline Regressão $15^{a}$ & 3,09 & 1.12 & Autocorr. Positiva & $(0.0000)$ \\
\hline Regressũo 16 & 1.03 & 2,00 & Ausência de Autocorr. & $(0.0000)$ \\
\hline Regressāo 17 & 1.77 & 1.97 & Ausência de Autocorr. & $(0,0000)$ \\
\hline Regressio 18 & 4.81 & 2,01 & Ausência de Autocorr. & $(0.0059)$ \\
\hline Regressão 19 & 1,90 & 1,87 & Ausência de Autocorr. & $(0.0000)$ \\
\hline
\end{tabular}


Com base nos resultados do teste de DURBIN-WATSON, que mede a autocorrelação nos resíduos, verifica-se autocorrelação positiva nas regressões 1 , 4, 14, 14(a) , 15 e 15 (a). A autocorrelação nos resíduos não possui impacto na especificação dos parâmetros, ponto de interesse do trabalho ${ }^{61}$. A interpretação do fato de existir correlação somente em parte da amostra, por outro lado, pode levar a conclusões interessantes. A existência de autocorrelação positiva nos anos de 1998 e 1999 (regressões 14, 14(a) , 15 e 15(a)) parece indicar a existência de um choque externo que impactou de forma uniforme toda a amostra. Tal choque pode estar relacionado com eventos macroeconômicos que influenciaram de maneira uniforme toda a base de dados. Estudos posteriores podem ser realizados para investigar a real causa do fenômeno. Para as finalidades específicas do trabalho, e dentro do conjunto de regressões realizados, a existência de autocorrelação positiva nos 6 (seis) casos analisados não empobrece as evidências produzidas.

A questão da multicolinearidade ${ }^{62}$ tem sido abordada com bastante cuidado nos trabalhos empíricos de contabilidade financeira. Essa preocupação existe porque muitas vezes as variáveis explicativas possuem forte relação, como o caso do patrimônio e dos resultados anormais nesse trabalho. No entanto, alguns comentários iniciais são importantes para que a multicolinearidade seja adequadamente avaliada. Como comenta GUJARATI (2000: 317) citando LEAMER (1983:300-301):

"Não há uma expressão mais incorretamente empregada nos livros de Econometria e literatura aplicada do que o 'problema da multicolinearidade'. Que muitas de nossas variáveis explicativas são colineares é um fato natural. E está clarissimo que existem dados

\footnotetext{
${ }^{61}$ A existência de autocorrelação aumenta a variância dos dados e pode levar a rejeição de hipóteses que deveriam ser aceitas (JOHNSTON, 1997:1 I2). Esse problema cria um viés em termos de aumentar a possibilidade de rejeição das hipóteses do trahalho. Assim, o impacto é pequeno para as conclusōes apresentadas.

6. Falando-se aqui de multicolinearidade dentro do sentido amplo do termo como comenta GUJARATI (2000:318) "Rigorosamente falando, multicolinearidade se refere à existência de mais de uma relação linear exata, enquanto a colinearidade se refere à existência de uma única relação linear. Mas tal distinção raramente se sustenta na prática, de modo que a multicolinearidade se refere a ambos os casos."
} 
experimentais $X^{\prime} X$, isto é, matrizes de dados que deveriamos preferir aos que um experimento natural nos tenha fornecido, ou seja, à amostra à mão. Mas uma queixa sobre a aparente malevolência da natureza não é de forma alguma construtiva, e as curas ad hoc para um modelo, tais como as regressōes passo a passo ou a de topo, podem ser desastrosamente inadequadas. É melhor aceitarmos corretamente o fato de que nossos nāo-experimentos, isto é, dados não-coletados por experimentos controlados às vezes não nos informam muito sobre os parâmetros de interesse."

Observa-se que o problema da multicolinearidade é um fato indiscutivel em muitos trabalhos empíricos. Nesse trabalho, optou-se pelo trabalho com os dados da forma mais 'pura' possivel, isto é, sem tratamentos especiais na amostra inicial para que informações relevantes não sejam perdidas. Nesse contexto, cabe perguntar qual o impacto da multicolinearidade, se existente em alto grau $^{63}$, nos resultados e conseqüentes interpretação dos resultados do trabalho empírico? Nesse sentido GUJARATI (2000:324) citando ACHEN (1982:82-83) responde :

"Estudantes principiantes de metodologia às vezes se preocupam com o fato de suas variáveis independentes estarem correlacionadas - o assim chamado problema da multicolinearidade. Mas a multicolinearidade não viola nenhuma hipótese de regressão. Estimativas não viesadas e consistentes vão ocorrer, e seus errospadrão serão corretamente estimados. $O$ único efeito da multicolinearidade é tornar dificil a obtenção de estimativas de coeficientes com pequeno erro-padrão. Mas ter um número pequeno de observações também tem esse efeito, assim como ter variáveis independentes com pequenas variâncias. ( Na verdade, em nivel

\footnotetext{
${ }^{63}$ A existência ou não da multicolinearidade é uma questão irrelevante. O aspecto importante desse problema é o grau de sua ocorrência, como comenta KMENTA (1986:431): "Multicolinearidade é uma questão de grau e năo de espécie. A distinção signiticcativa a fazer não é entre a presença ou a ausência de multicolinearidade, mas entre os seus diferentes graus."
} 
teórico, multicolinearidade, poucas observaçōes e pequenas variâncias nas variáveis independentes são, basicamente, o mesmo problema.) Assim, "O que devo fazer com o a multicolinearidade?" é uma questão semelhante a "O que devo fazer se não tiver muitas observações?". Nenhuma resposta estatística pode ser dada."

Em aplicações de regressões lineares múltiplas, como esse trabalho, o maior problema advindo da multicolinearidade refere-se ao fato de que embora a razão de $t$ de um ou mais coeficientes seja estatisticamente insignificante, $\mathrm{R}^{2}$, a medida global do grau de ajuste, pode ser bastante alto. Esse aspecto apresenta pouca importância para este trabalho, uma vez que nas regressões onde os coeficientes $t$ são insignificantes estão sendo analisadas como irrelevância das variáveis explicativas em relação à variável dependente.

Conforme comentado acima, 'o problema da multicolinearidade' reside na interpretação dos resultados. Nas equações 1 a 10 (comparação do modelo baseado no lucro contábil e nos dividendos) a presença de maior número de coeficientes $t$ estatisticamente insignificantes no modelo baseado nos dividendos demonstra a superioridade da especificação baseada nos números contábeis, de forma geral. No entanto, no caso de situações como a comparação das equações 7 e 10, para as quais os coeficientes t são estatisticamente significantes no nivel de $1 \%$ e ambas possuem $R^{2}$ relativamente altos $(0,84$ para $\circ$ modelo de dividendos e 0,93 para o modelo contábil) conclui-se que as especificações são semelhantes. Por esse motivo optou-se pela não realização de testes estatísticos ${ }^{64}$ para a comparação dos poderes explicativos das regressões. Dessa forma, o grande risco advindo da multicolinearidade (altos $R^{2}$ com coeficientes $t$ insignificantes) não impactam negativamente os resultados do trabalho. Outro aspecto desta tese que reduz a importância da multicolinearidade é que não se está querendo provar, a priori, este ou aquele modelo. Esse aspecto levou a utilização da amostra em sua forma mais 'pura' possivel e a não utilização de outras técnicas para 'forçar' os resultados.

${ }^{6+}$ Assim, a interpretação ficà centrada nos coeticientes e não nos resultados do $\mathrm{R}^{2}$ 
Finalmente é necessário analisar os problemas da heterocedasticidade e dos efeitos de escala (scale effects). Esses são dois dos pontos mais contraditórios na pesquisa em contabilidade financeira. Como será visto a seguir, o tratamento desses problemas. depende fundamentalmente dos objetivos da pesquisa e da 'sensibilidade' do pesquisador. Inicialmente, faz-se necessário o esclarecimento de alguns aspectos acerca da heterocedasticidade e do efeito de escala. Esses problemas serão abordados de forma conjunta neste trabalho devido à natureza dos mesmos.

A heterocedasticidade é uma violação de uma das premissas do modelo clássico de regressão linear (MCRL de agora em diante), que é o utilizado neste trabalho. A premissa é que a variância de cada termo de perturbação ${ }^{65} v_{i}$, condicional aos valores escolhidos das variáveis explicativas, é algum número constante igual a $\sigma^{2}$. Formalmente:

$$
E\left(v_{i}^{2}\right)=\sigma^{2} \quad \text { para } i=1,2, \ldots, n
$$

O problema da heterocedasticidade é mais comum em dados em corte (como neste trabalho) do que em séries temporais. Sucintamente ${ }^{66}$, a grande consequência da utilização do MCRL na presença de heterocedasticidade é que os coeficientes estimados continuarão a ser não-viesados mas não serão, necessariamente, os melhores estimadores (menor variância). A existência desse problema torna a inferência mais difícil devido à flutuação nas variâncias ao longo da amostra. O efeito de escala pode ser ilustrado como em BROWN et all (1999:86-87):

"To ilustrate the effect of scale on $R^{2}$ consider de bivariate relation between $z=\left(z_{1}, \ldots, z_{n}\right)$ e $w=\left(w_{1}, \ldots, w_{n}\right)$. Assuming that the underlying relation between the two variables is linear we can write:

${ }^{65}$ Referido como termo de erro da regressão ao longo deste trabalho.

${ }^{66}$ Para um tratamento mais profundo, porém claro ver GUJARATI (2000:354-400) 


$$
z_{l}=\alpha+\beta w_{l}+\varepsilon_{l}
$$

Equation (1) models the relation "free of scale". One might think of $z_{i}$ as value of a stock at the end of a period that results from investing $\$ 1$ in each of the $n$ assets. In other words, the initial value of the dependent variable is the same across all observations before the experiment and all the variation in the dependent variableoccurs in the experimental period. In such a research design, one may correctly say that $R^{2}$ represents the explanatory power of the independent variables.

However, a researcher may not be able to observe the data free of scale as represented in Eq. (1). Alternatively, the research question may demand an analysis using scale-affected rather than scale-free data. In either case, the scale effect is present and likely to differ across samples. To investigate the consequences of scale on the regression $R^{2}$, assume that the observed data are affected by a scale factor $s+\left(s_{1}, \ldots, s_{n}\right)$, resulting in

$$
s_{i} z_{l}=\alpha s_{l}+\beta s_{i} w_{l}+s_{i} \varepsilon_{l}
$$

$\mathrm{Na}$ assertiva acima o autor apresenta a forma de um efeito de escala multiplicativo ${ }^{67} .0$ impacto da presença de efeitos de escala é que o poder explicativo da regressão pode ser exagerado devido às variações causadas por diferentes tamanhos de empresas, por exemplo. Uma das formas de evitar os efeitos de escala é a divisão dos termos da regressão por um fator comum, relacionado a uma proxy para o efeito considerado (normalmente tamanho da empresa como feito nas regressões 20-24).

${ }^{67}$ Existem outros tipos como pode ser visto em BARTH e CLINCH (1999). 
A existência de heterocedasticidade vem normalmente acompanhada de efeitos de escala de forma que os dois fenômenos podem ser analisado conjuntamente. Existem muitas abordagens para o tratamento desses problemas. Muitos autores argumentam que a existência de heterocedasticidade não deve causar preocupação, conforme GUJARATI (2000:354) citando MANKIW (1990:1648):

"A heterocedasticidade nunca foi um motivo para rejeitar um modelo que de um outro modo seria bom."

No entanto, outros autores como BROW et all (1999) mostram que os efeitos da heterocedasticidade e dos problemas de escala podem comprometer os resultados da análise levando a poderes explicativos $\left(R^{2}\right)$ excessivamente altos. Cabe então a análise das alternativas para a resolução do problema. A alternativa mais comum envolve o deflacionamento das variáveis do modelo por alguma proxy de tamanho. De acordo com BROWN et all (1999:105) a equação 15a, por exemplo, deveria ser especificada da seguinte forma:

$$
P_{\text {iA2000 }} / P_{\text {iA 1999 }}={ }_{99} \omega_{0 a}+{ }_{99} \omega_{1 a}\left(B V_{i g 9} / P_{\text {iA 1999 }}\right)+\varepsilon_{i 99}
$$

Ao invés da especificação originalmente utilizada:

$$
P_{1 A 2000}={ }_{99} \omega_{0 a}+{ }_{99} \omega_{1 \mathrm{a}} B V_{i 99}+\varepsilon_{i 9 g}
$$

O que consiste simplesmente no deflacionamento de todas as variáveis pelo preço do periodo anterior. Essa abordagem possui dois problemas essenciais: é totalmente ad hoc, no sentido de que é impossivel provar que o preço, ou qualquer outra variável, possui a capacidade de capturar o efeito da escala inteiramente. Como pode-se esperar, os resultados da regressão (15b) são iguais aos da regressão (15a) em termos da significância dos coeficientes da 
regressão e do teste de DURBIN-WATSON. No entanto, $\circ R^{2}$ difere significativamente indo de $0,79 \mathrm{em}$ (15a) para $0,24 \mathrm{em}(15 b)^{68}$. O segundo problema da especificação (15b) é que ela altera totalmente o modelo inicial. A divisão pelo preço das ações no ano anterior não só 'deflaciona' como muda completamente o valor da variável dependente. Nesse caso a redução, do poder explicativo pode dever-se a diferença de especificação e não nos efeitos de escala que se pretendia mitigar inicialmente.

Essa situação representa um ponto importante de decisão no tratamento empírico dos números contábeis. Se por um lado a utilização do modelo com possiveis efeitos de escala pode levar a $R^{2}$ exagerados, a utilização de um deflator inadequado pode levar a conclusōes ainda mais errôneas com problemas de especificação dos coeficientes que não existem na ausência de transformaçōes nos dados iniciais (15a). Conforme comenta BARTH e CLINCH (1999:6)

"Thus, deflation by number of shares outstanding may not remove all scale effects and can give rise to the reciprocal of shares outstanding becoming a correlated omitted variable. This introduced correlated omitted variables introduces coefficient bias, which we refer as deflation bias."

Neste trabalho, o problema de escala pode estar presente nas regressōes 1 a 15a que apresentam altos $R^{2}$. Ao invés de modificar a especificação das regressōes utilizadas conforme proposto por BROWN et all (1999:105) e criticado por BARTH e CLINCH (1999:6) optou-se pela adoção de alguns cuidados na interpretação dos resultados e na manutenção das especificações originais. Esses cuidados são os seguintes: 
1. Os coeficientes t e os referentes niveis de significância ( $p$-value) serão a base da interpretação dos resultados. Assim, o grau de significância dos coeficientes é que determinará o tratamento das hipóteses do trabalho;

2. Os valores de $R^{2}$ somente serão considerados de forma relativa. Isto é, serão utilizados somente para comparação entre modelos aplicados dentro da mesma amostra no mesmo intervalo temporal. Assim, evita-se que conclusões errôneas sejam obtidas.

Com essas restrições, acredita-se que a interpretação dos resultados do trabalho pode ser feita de forma coerente. A significância dos coeficientes não é afetada pelos problemas apresentados acima sendo, dessa forma, o critério que será utilizado na interpretação do trabalho. Cabe ressaltar que a restrição à utilização dos valores de $R^{2}$ refere-se somente a avaliação absoluta. Não existe razão aparente para impedir comparaçōes (avaliações relativas) entre tais valores.

É importante ressaltar que os problemas citados acima (heterocedasticidade, efeito de escala e autocorrelação) são, muitas vezes, completamente ignoradas na literatura em contabilidade financeira. Trabalhos como os de COLLINS et all (1997) ignoram grande parte da influência desses problemas assumindo que a especificação utilizada está correta a priori.

Finalmente, cabem algumas observaçōes sobre o problema de especificação em pesquisas na área de contabilidade financeira. A especificação refere-se a escolha do modelo ideal para o tratamento do conjunto de dados em questão. Tomando-se emprestado a experiência dos econometristas, pode-se observar em GUJARATI (2000: 483)

“...a metodologia econométrica tradicional supõe um modelo econométrico em particular e tenta verificar se ele se ajusta a um determinado conjunto de dados. Assim, se o modelo for a função 
consumo keynesiana (em que o consumo observado é uma função da renda observada0 ou a função de consumo de Friedman (em que - consumo permanente é função da renda permanente), o pesquisador pegará uma dessas funções consumo como dado $e$ tentará verificar se os dados disponiveis a sustentam. A decisão de rejeitar ou não uma função consumo em particular se baseia nos diagnósticos de regressão usuais, tais como $R^{2}, t, F$ e estatística $d$ de Durbin-Watson.

Os críticos dessa tradição de REM (regressão econômica média) afirmam que, nos dados coletados não experimentalmente, que representam a maior parte nas pesquisas econômicas práticas, esta estratégia é seguramente questionável. Para eles, uma vez que o modelo seja dado, estimar seus parâmetros e passar para o teste de hipóteses é simples. Mas a tarefa que demanda grande esforço é, antes de mais nada, determinar qual modelo é o apropriado".

Essas consideraçōes refletem a preocupação de muitos pesquisadores com a escolha do modelo utilizado no tratamento dos dados e o respectivo diagnóstico do mesmo. Ao longo deste trabalho e nas seçōes subsequentes, utilizou-se uma abordagem alternativa à REM chamada de abordagem de HENDRY. Segundo essa abordagem, deve-se partir de um modelo geral para o específico de acordo com a relevância das variáveis utilizadas. A idéia que fundamenta tal abordagem é que grande parte da teoria econômica e por consequência os modelo por ela gerados são relaçōes de equilibrio estabelecidas no longo prazo. Por outro lado, os dados utilizados para o teste de tais teorias são coletados em intervalos de tempo menores e sem a mesma disponibilidade de informações que a teoria pressupõe. Conforme explica GUJARATI (2000:488):

"A abordagem de Hendry ou LSE (London School of EconomicsEscola de Economia de Londres) para a modelagem econômica é 
popularmente conhecida como abordagem de cima para baixo ou do geral para o específico, uma vez que começamos com um modelo com diversos regressores e então reduzimos gradualmente a um modelo contendo apenas as variáveis 'importantes' “.

Neste trabalho adota-se uma versão modificada da abordagem de HENDRY ${ }^{69}$, pois buscou-se sempre que possivel a estimação de modelos mais amplos e sua redução em busca de versões mais simplificadas com significância semelhante. De acordo com HENDRY e RICHARD (1983: 17) um modelo simplificado deve satisfazer aos seguintes critérios:

1. Ser admissivel em relação ao conjunto de dados utilizados: enfocando na lógica interna do modelo com os resultados;

2. Ser compativel com a teoria: os resultados devem ser coerentes com a teoria existente. Nāo quer dizer que os dados tenham que ser 'adaptados' à teoria. No entanto, para que a teoria seja aceita esta deve ser coerente com os resultados encontrados;

3. Ter regressores fracamente exógenos: os regressores não devem ter correlação com o termos de erro;

4. Exibir constância nos parâmetros: este é o aspecto mais importante da abordagem de HENDRY. Para que o modelo simplificado tenha sentido e possa, eventualmente, ser superior a um modelo mais complexo os parâmetros devem ser razoavelmente constantes. Ao menos devem ser mais estáveis do que os parâmetros do modelo em comparação. Esse aspecto de estabilidade facilita a predição que é uma das caracteristicas mais importantes da teoria dentro da abordagem positiva, conforme comentado no capitulo 2; 
5. Exibir coerência nos dados: refere-se a aleatoriedade dos resíduos;

6. O modelo deve ser superior aos modelos rivais.

O item 4 possui papel especial neste trabalho uma vez que a interpretação dos outros quesitos é feita naturalmente dentro dos outros testes realizados no trabalho. Nas equações 11 a 15a compara-se o poder da especificação baseada no patrimônio com àquela baseada no lucro e no patrimônio para explicar o comportamento dos preços das ações analisadas. Baseado no exposto acima pode-se comparar a estabilidade dos parâmetros das regressōes utilizadas. $O$ gráfico I abaixo compara (linha rosa) os coeficientes da variável patrimônio líquido (BV) encontrado nas regressões onde esta variável é a única variável independente $(11 a, 12 a, 13 a, 14 a, 15 a)$, com os (linha azul) coeficientes da variável lucro líquido (Luc) nas regressões onde está variável aparece conjuntamente como o patrimônio $(11,12,13,14,15)$. Pode-se observar claramente que a linha do patrimônio liquido apresenta maior estabilidade do que a relativa ao lucro demonstrando a maior estabilidade do modelo simplificado. Nos resultados apresentados na seção 'Lucros vs. Dividendos' procurou-se avaliar qual o modelo que melhor adapta-se à explicação dos preços. Da mesma forma que realizado anteriormente pode-se comparar a estabilidade dos parâmetros das regressões realizadas. Neste caso, como será discutido a seguir, verificou-se forte evidência favorável à hipótese da fixação funcional. Dessa forma os números de curto prazo apresentam relevância maior do que aqueles dispersos em periodos mais distantes. Assim, o gráfico II compara a estabilidade dos coeficientes relativos ao patrimônio na regressão das variáveis contábeis (linha rosa) com àqueles (linha azul) relativos aos dividendos pagos no ano seguinte à data de coleta dos preços (Div). Assim, para os dados apresentados na tabela 5.2 (preços de 1995) o gráfico II apresenta o coeficiente do patrimônio de 1995 e o valor dos dividendos pagos em 1996, e assim sucessivamente para os outros anos. 


\section{GRÁFICO I}

Estabilidade dos Coeficientes das Regressőes do Grupo "Poder Explicativo das Variáveis Contábeis

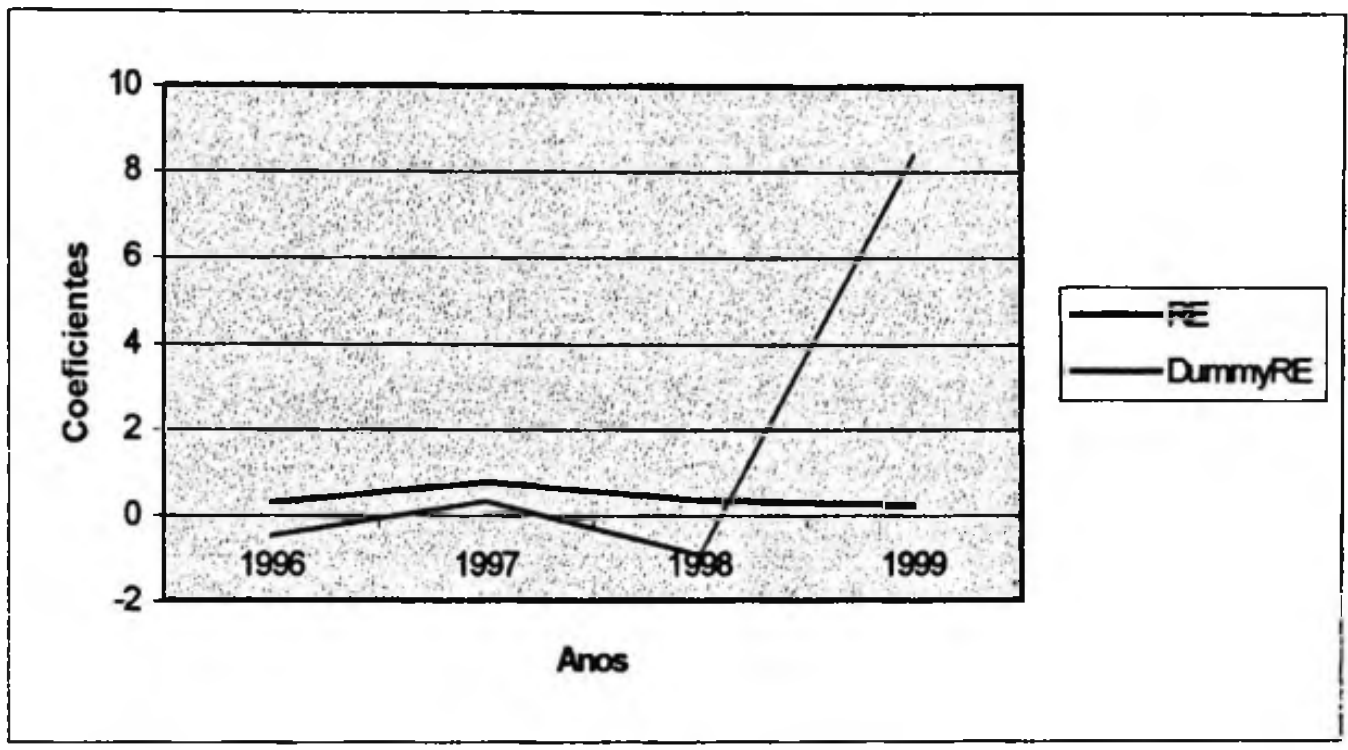

\section{GRÁFICO ॥}

Estabilidade dos Coeficientes das Regressões do Grupo "Lucro vs. Dividendos"

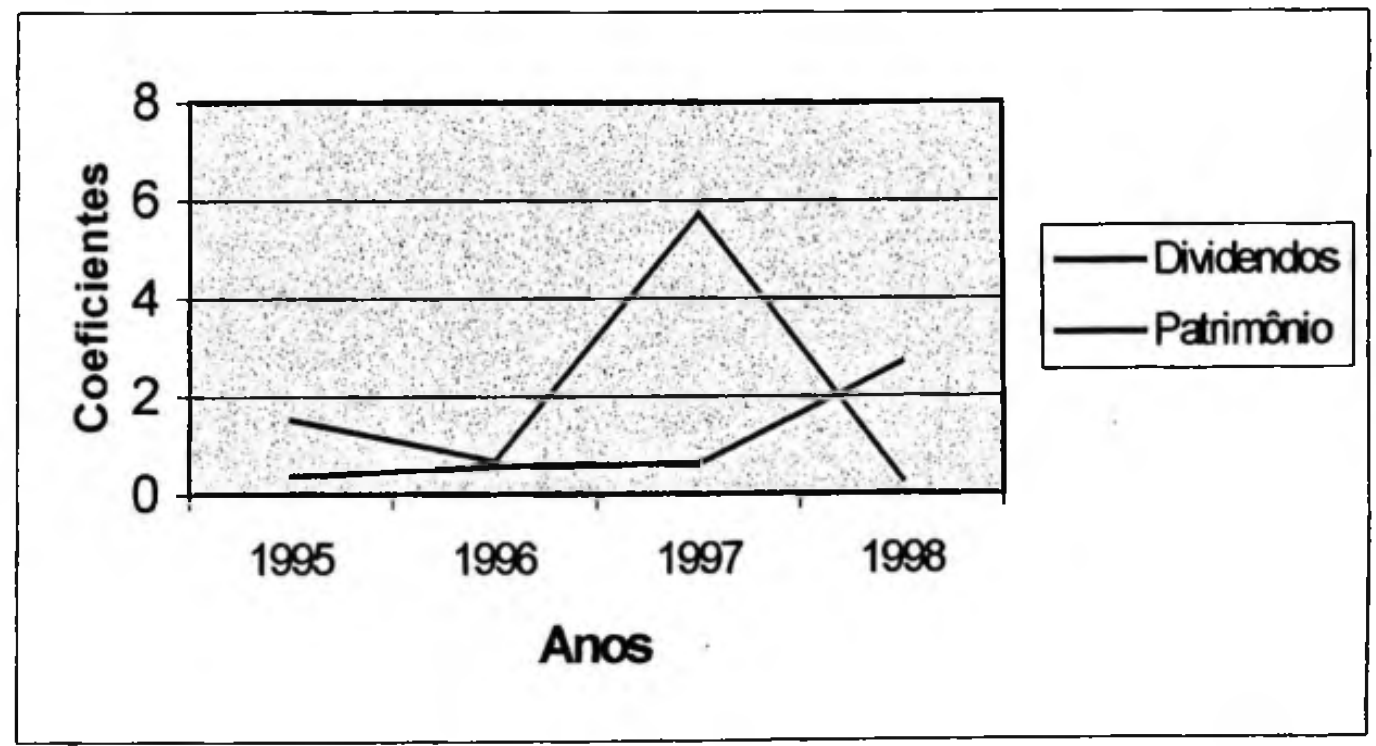

maioria dos trabalhos de HENDRY. No entanto, a filosofia utilizada é a mesma. 
Os resultados apresentados nos gráficos I e II demonstram claramente a diferença entre a estabilidade de ambos coeficientes levando a conclusão, de acordo com a abordagem de HENDRY, que no gráfico I o modelo simplificado centrado no patrimônio explica melhor o comportamento dos preços correntes (Abril do ano seguinte neste caso). No gráfico II verifica-se o mesmo cenário em termos da comparação do patrimônio com o modelo baseado em dividendos futuros.

Essas conclusões podem ser claramente estendidas para os resultados apresentados no item 5.4 'Reconhecimento e Conservadorismo'. Nessa seção anzlisz-se a capacidade do resultado contábil incorporar o econômico e o conservąorismo (assimetria) deste. Para aplicar a abordagem proposta por $4750 K Y$ basta que os coeficientes relativos ao resultado contábil sozinho ( $\psi R E)$ sejam comparados com os coeficientes relativos ao lucro contábil ajustado pela variável dummy para os resultados negativos ( $\left.\psi D_{i} R E\right)$. O gráfico III abaixo apresenta esses resultados.

\section{GRÁFICO III}

Estabilidade dos Coeficientes das Regressōes do Grupo 'Reconhecimento e Conservadorismo'

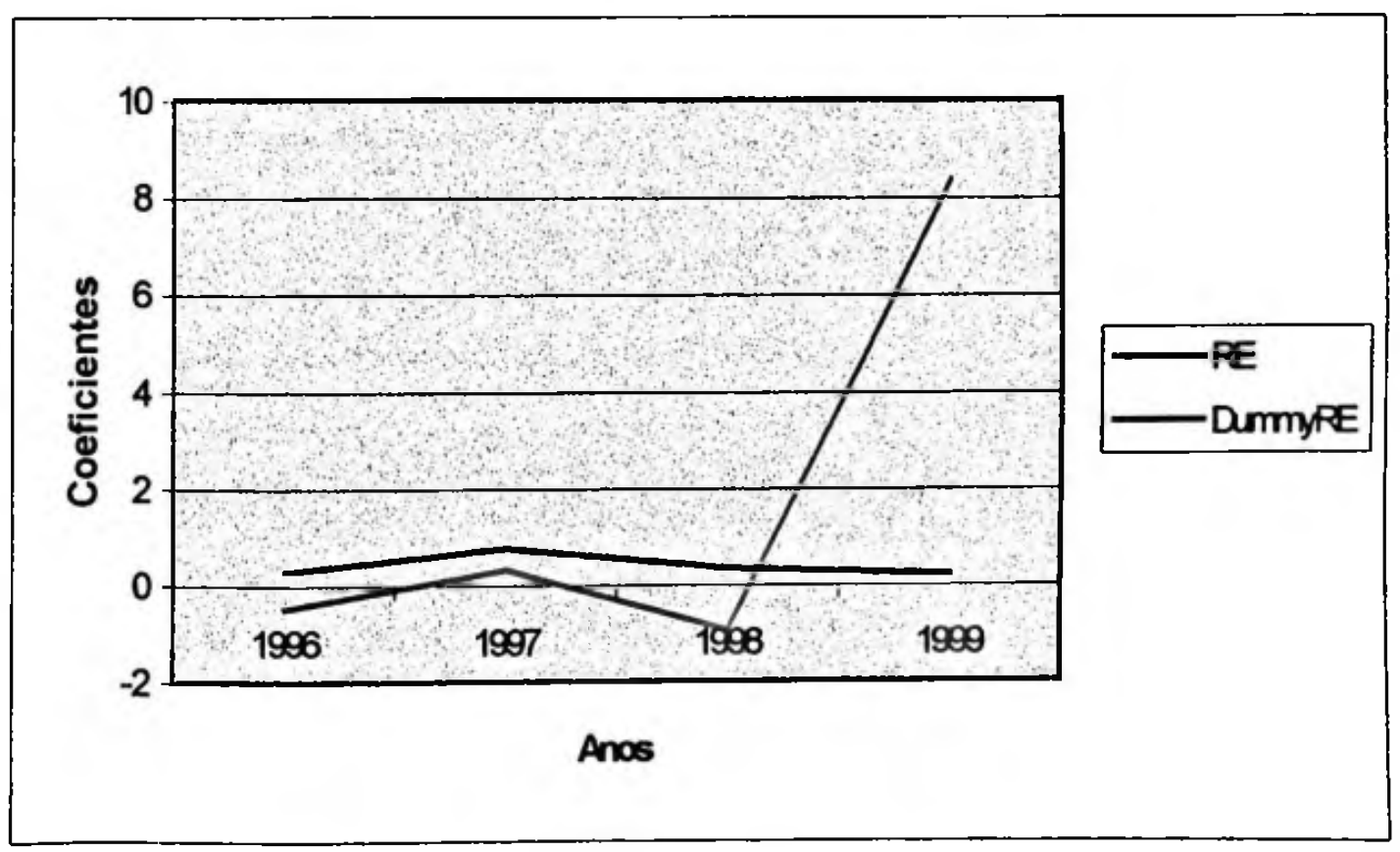


Novamente, pode-se observar nitidamente que os coeficiente relativos ao resultado econômico (linha azul) são mais estáveis do que os relativos ao resultado econômico modificado (linha rosa).

\subsection{Informações Fornecidas, Interpretação e Extensão dos Resultados}

Os resultados encontrados permitem a formulação das seguintes conclusões gerais:

- Ornodelo baseado em variáveis contábeis (OHLSON) apresenta maior riglevância estatística para explicar o comportamento dos preços relativos (cross section) do que o modelo baseado em dividendos futuros. Dessa forma, a hipótese $H_{0 a}$ não pode ser rejeitada. Essa superioridade, no entanto, não é significativa, levando a conclusão de que ambos os modelos (contábil e financeiro) apresentam resultados semelhantes;

- A maior parte do poder explicativo do modelo contábil reside na importância do valor do patrimônio líquido das empresas analisadas. Conforme os resultados, os lucros anormais futuros não apresentam grande importância;

- A hipótese da fixação funcional não pode ser rejeitada. Aparentemente, no Brasil, investidores e demais usuários da informação contábil preocupam-se primordialmente com o curto prazo. Essa conclusão baseia-se nos resultados das regressões 1 a 10;

- A hipótese $\boldsymbol{H}_{0 b}$ não pode ser rejeitada. Os números contábeis explicam de forma significativa o comportamento dos preços relativos (cross section) dentro da amostra utilizada. $O$ intercepto das regressões parece 
não ser significativo enquanto que os coeficientes são todos significativos no nivel de $1 \%$. O gráfico abaixo (GRÁFICO IV) apresenta a evolução do poder explicativo dos números contábeis (patrimônio e lucro) dentro do período analisado. Esse gráfico deve ser interpretado de forma relativa e não absoluta;

\section{GRÁFICO IV}

Evolução do Poder Explicativo do Património e do Lucro e Patrimônio

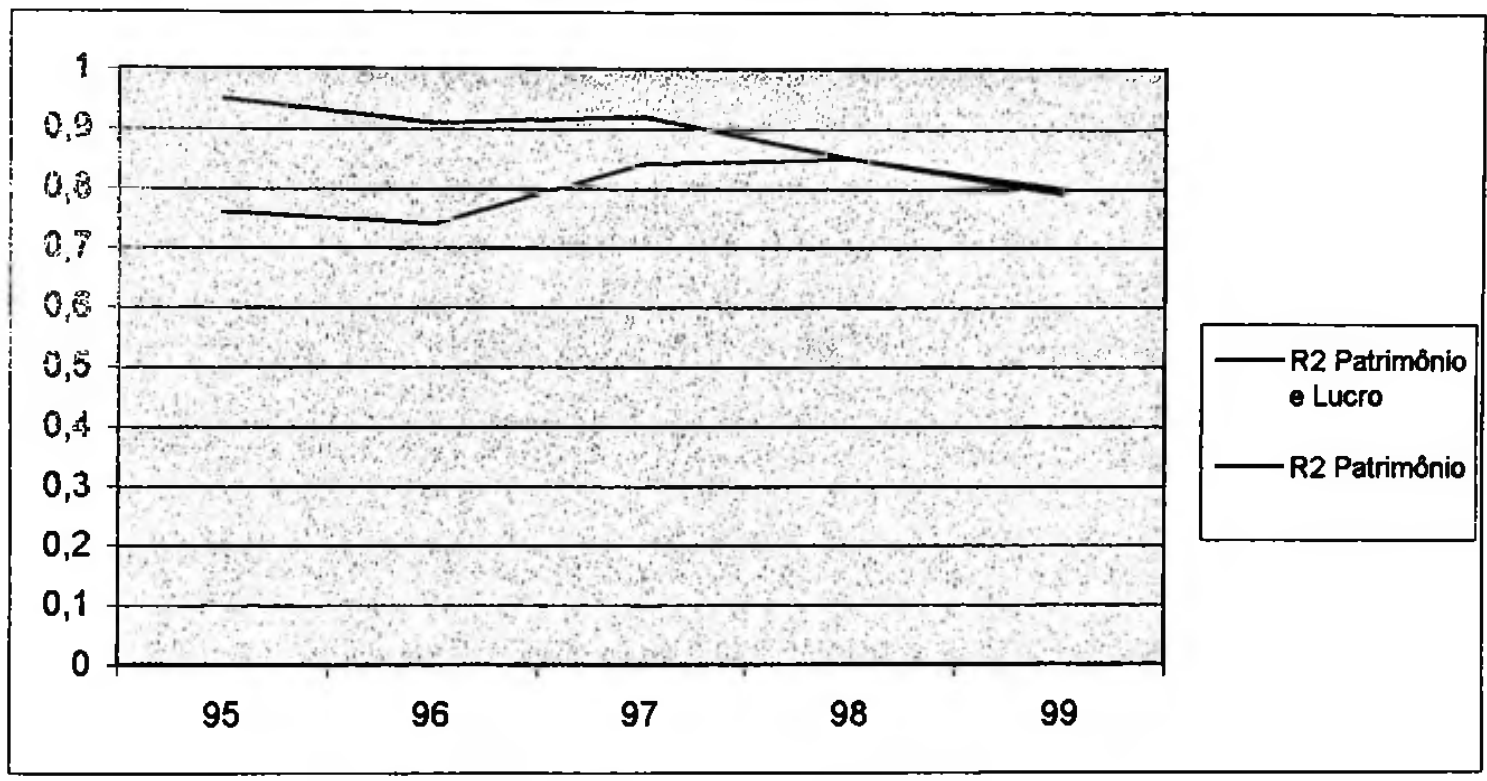

- O valor do património, independentemente, é extremamente significante para a explicação do comportamento dos preços relativos (cross section) conforme pode ser visto pelo gráfico acima (GRÁFICO IV) ;

- A hipótese $H_{0 c}$ pode ser rejeitada pelos resultados devido à significância dos coeficientes estimados nas regressōes;

Observa-se um aumento do conservadorismo nos números apresentados no ano de 1999 com respectivo aumento das propriedades dos valores contábeis para explicar o comportamento dos preços relativos, em relação aos anos 
anteriores. O gráfico abaixo (GRÁFICO V) relaciona os valores dos coeficientes $\psi_{3}$ relativos ao reconhecimento assimétrico em relação aos anos analisados com os valores do índice patrimônio/valor de mercado (BTM).

\section{GRÁFICO V}

Relação Entre o Indice Patrimônio/Nalor de Mercado (BTM) e o Coeficiente de Reconhecimento Assimétrico $\left(\psi_{3}\right)$

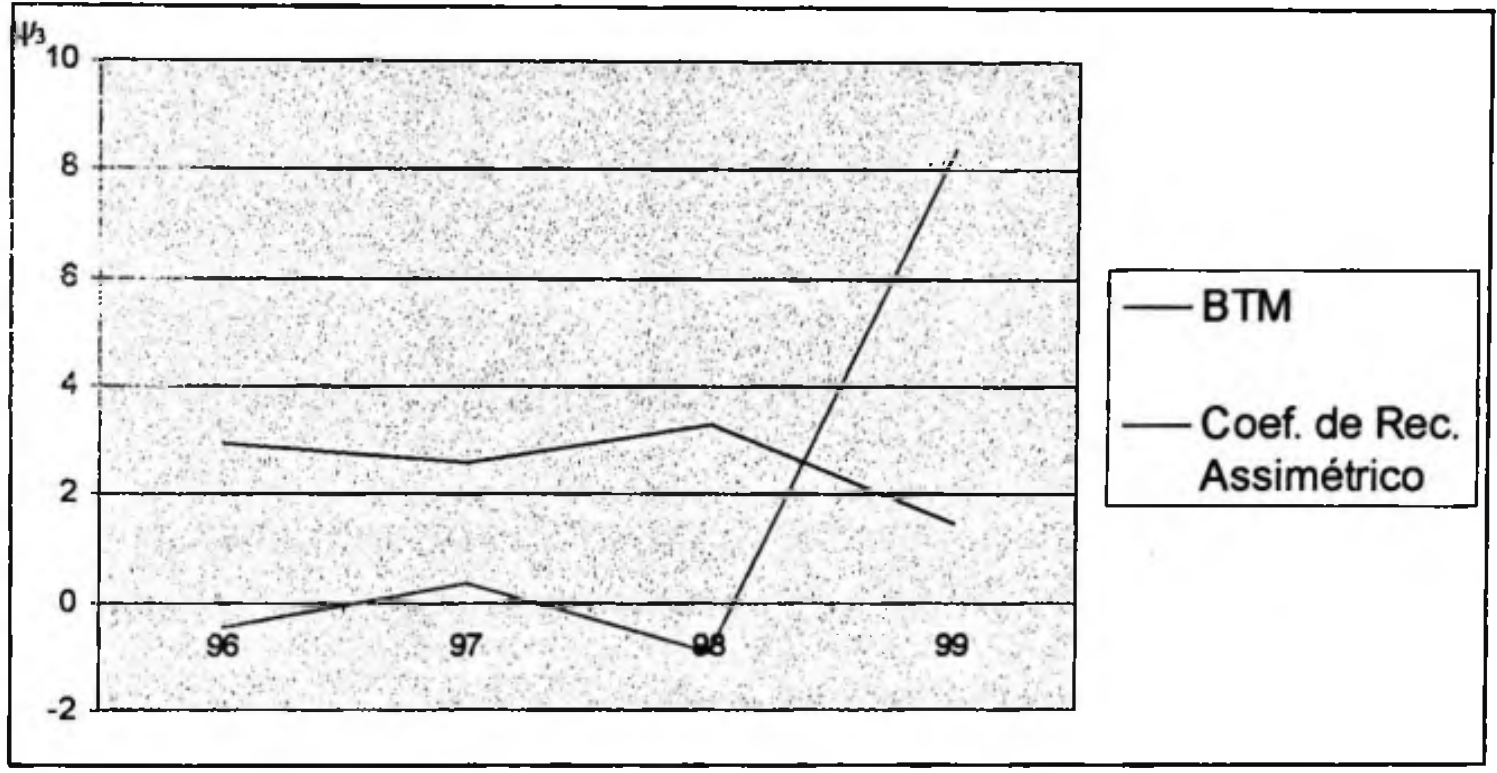

As duas variáveis apresentadas comportam-se de acordo com o esperado segundo a teoria: comportamento ligeiramente oposto. Quanto maior o indice BTM menos conservador é o modelo contábil enquanto que 0 coeficiente de reconhecimento assimétrico cresce à medida que o sistema contábil torna-se mais conservador. De acordo com a revisão bibliográfica realizada e com o conhecimento do autor, essa é a primeira vez que tal relação teórica é sistematicamente verificada.

Tradicionalmente verifica-se na literatura que os coeficientes relacionados aos resultados normais e os resultados ajustados pela variável dummy (sendo neste trabalho $\psi_{2} \quad 0$ coeficiente representando os resultados reais e $\psi_{3}$ representado os resultados ajustados pela variável dummy) apresentam 
comportamentos distintos. Os resultados encontrados neste trabalho corroboram essa hipótese devido aos valores dispares apresentados pelas variáveis $\psi_{2}$ e $\psi_{3}$.

No entanto, esses resultados não permitem que duas questões centrais sejam respondidas: (i) qual o papel do lucro contábil para explicar os retornos dos preços das ações sob análise? (ii) existe alguma diferenciação entre setores de atividade: "velha" versus "nova" economia no que concerne ao papel do lucro e do patrimônio? Essas questões não puderam ser respondidas dentro das limitações da amostra selecionada que não possui informações suficientes para a segregação entre setores durante o período analisado. A segunda apresenta importância especial na medida que permite, dentro de uma adequada seleção da amostra, a comparação do papel da contabilidade para explicar o comportamento do preço das açōes de empresas de setores com alto montante de intangiveis. Esse aspecto é importante porque muitos autores (LEV, 1989; sendo o mais eloqüente) tem argumentado que a contabilidade vem perdendo importância relativa na medida que as empresas passam a ser mais dependentes em ativos intangiveis que não são captados pelo modelo de mensuração tradicional da contabilidade. Dessa forma, é importante o teste substantivo em amostras com empresas de setores mais tradicionais seguida de comparação com empresas menos baseadas em ativos fixos. Para avaliar essa questão, o modelo proposto por HARRIS et all (1994: 205) será utilizado:

$$
\left(P_{j t}+d_{j t}-P_{j t-1}\right) / P_{j t-1}=\alpha_{0 t}+\alpha_{1 t}\left(L u c_{j t}-L u c_{j t-1}\right) / P_{j t-1}+\alpha_{2 t} L u c_{j t} / P_{j t-1}+g_{j t}
$$

Onde:

$\mathbf{P}_{\mathrm{jt}}=$ preço das açōes da empresa $\mathbf{j}$ no final do ano $\mathbf{t}$ (neste caso 1999);

$P_{\mathrm{jt}-1}=$ preço das ações da empresa $\mathbf{j}$ no final do ano $t-1$ (neste caso 1998);

$d_{j t}=$ dividendos distribuídos durante 0 ano $t$, por ação (1999);

$\operatorname{Luc}_{\mathrm{j}}=$ lucro contábil da empresa $\mathbf{j}$ durante o ano $t$, por ação (1999);

$L_{u c_{\mid t-1}}=$ lucro contábil da empresa $\mathbf{j}$ durante $\mathrm{o}$ ano $\mathbf{t}$, por ação (1998); 
$\zeta_{j t}=$ termo de erro da regressão;

A regressão (20) tenta demonstrar o poder de explicação da flutuação do lucro e do lucro como variáveis independentes em relação ao retorno das ações das empresas consideradas (variável dependente). Os coeficientes da regressão e o poder explicativo da mesma podem fornecer maiores esclarecimentos acerca das propriedadades do lucro contábil no Brasil.

Para a realização dessa regressão foi selecionada uma nova amostra dentro do mesmo banco de dados (ECONOMATICA) correspondendo aos anos de 1999 e 1998. Foram excluídos pontos sem observações conforme a seleção anterior. Em adição, a amostra foi separada em empresas com base em ativos fixos (chamado de FIXO de agora em diante) e empresas com forte participação de ativos intangiveis (chamado de INTANGiVEL de agora em diante). O grupo FIXO é composto por empresa do seguinte setores: empresas siderúrgicas, têxtil, metalurgia, mecânico industrial, químico, mineração, petroquímico. O grupo INTANGiVEL é composto exclusivamente por empresas do setor de telecomunicações ${ }^{70}$. Foram selecionadas 73 empresas para o setor INTANGÍVEL e 91 empresas no grupo FIXO. A escolha do periodo (1998-99) deve-se unicamente à inexistência de dados para as empresas do setor INTANGÍVEL em quantidade suficiente para a comparação com o setor FIXO em periodos anteriores. Conforme comentado anteriormente, não foram realizadas modificaçōes adicionais na amostra. As estatísticas descritivas dessa nova amostra para o periodo considerado estāo apresentadas na tabela abaixo.

\footnotetext{
${ }^{70}$ Normalmente são consideradas como empresas baseadas em ativos intangiveis as empresas do grupo de empresas de telecomunicações, mídia e tecnologia (TMT, como sāo normalmente referidas na literatura). A predominância de empresas de telecomunicaçōes neste trabalho deve-se unicamente as limitaçōes da amostra.
} 
TABELA 5.17 Estatísticas Descritivas para a Amostra II

\begin{tabular}{|c|c|c|c|c|c|}
\hline INTANGiVEL & Média & Desvio Padrão & Mediana & Máximo & Mínimo \\
\hline Preço 1998' & 10,94 & 19,99 & 0,029835 & 118,0101 & 0,0001 \\
\hline Preço 1999 & 17,70 & 28,34 & 0,069682 & 113,552 & 0,00004 \\
\hline Lucro 1998 & 0,168 & 0,9663 & 0,000861 & 5,885395 & $-0,0122$ \\
\hline Lucro 1999 & 0.153873 & 0,925748 & 0,0000279 & 5,631093 & $-0,06667$ \\
\hline Dividendos 99 & 0,1763 & 1,0464 & 0,0000607 & 6,368 & 0 \\
\hline FIXO & Média & Desvio Padrão & Mediana & Máximo & Mínimo \\
\hline Preço 1998 & 1,7156 & 5,5469 & 0,0235 & 40,2593 & 0,0000193 \\
\hline Preço 1999 & 3,9578 & 11,7645 & 0,0578 & 67,16 & 0,00008 \\
\hline Lucro 1998 & $-4,24083$ & 30.7589 & 0,000725 & 12,575 & $-245,373$ \\
\hline Lucro 1999 & $-0,13915$ & 3,3634 & 0,0014 & 12,4275 & $-24,1607$ \\
\hline Dividendos 99 & 0,18579 & 0,92114 & 0,000326 & 8.2 & 0 \\
\hline
\end{tabular}

A regressão (20) produziu os seguintes resultados reportados na tabela abaixo. Os valores entre parênteses representam os coeficientes de sifnificância $p$ (p-value) dos coeficientes ${ }^{72}$ :

TABELA 5.18 Resultados da regressão (20) para os grupos FIXO e INTANGIVEL

\begin{tabular}{|c|c|c|c|c|c|c|}
\hline Grupos & $\mathrm{N}^{0}$ Empresas & $\alpha_{0 t}$ & $\alpha_{1 t}$ & $\alpha_{2 t}$ & $\mathrm{R}^{2}$ & Durbin-Watson \\
\hline INTANGIVEL & 73 & $\begin{array}{c}1,52 \\
(0,0000)\end{array}$ & $\begin{array}{c}-0,39 \\
(0,0019)\end{array}$ & $\begin{array}{c}1,61 \\
(0,021)\end{array}$ & 0,147 & $\begin{array}{l}\text { Ausência de } \\
\text { Autocorrelaçăo }\end{array}$ \\
\hline FIXO & 91 & $\begin{array}{c}2,17 \\
(0,0000)\end{array}$ & $\begin{array}{c}-0,069 \\
(0,0275)\end{array}$ & $\begin{array}{c}0,08 \\
(0,0612)\end{array}$ & 0,055 & $\begin{array}{c}\text { Ausência de } \\
\text { Autocorrelação }\end{array}$ \\
\hline TOTAL $^{73}$ & 164 & $\begin{array}{c}1,86 \\
(0,0000)\end{array}$ & $\begin{array}{c}-0,065 \\
(0,0192)\end{array}$ & $\begin{array}{c}0,03 \\
(0,0486)\end{array}$ & 0,034 & $\begin{array}{l}\text { Ausência de } \\
\text { Autocorrelaçāo }\end{array}$ \\
\hline
\end{tabular}

\footnotetext{
${ }^{71}$ Os preços correspondem à média do último mês do ano correspondente.

${ }^{72}$ Optou-se por reportar o valor p diretamente ao invés da estatística para que se possa interpretar diretamente o resultado.
} 
Os resultados acima demonstram que os coeficientes são estatisticamente significantes demonstrando que o lucro contábil é uma variável estatisticamente significante para a explicação doṣ retornos das empresas analisadas. No entanto, - poder explicativo das regressões é baixo o que indica que, apesar de estatisticamente significante, o lucro contábil explica parcela reduzida do retorno. O fator mais interessante da regressão acima é o fato de que o grupo INTANGIVEL apresentou comportamento semelhante ao grupo FIXO em termos de especificação da regressão e com poder explicativo superior. Assim, não existem evidências favoráveis ao argumento (LEV, 1989) de que a contabilidade perde relevância para explicar o comportamento de empresas de setores baseados em ativos intangiveis. Esses resultados complementam os apresentados anteriormente mostrando que o lucro contábil é variável importante no cenário brasileiro, apesar de possuir baixo poder explicativo.

Para complementar a análise realizada, propõe-se o seguinte modelo para avaliar o papel do patrimônio na explicação do comportamento do retorno das empresas selecionadas na amostra:

$$
\left(P_{j t}+d_{j t}-P_{j t-1}\right) / P_{j t-1}=\kappa_{0 t}+\kappa_{1 t}\left(B V_{j t}-B V_{j t-1}\right) / P_{j t-1}+\kappa_{2 t} B V_{j t} / P_{j t-1}+\varsigma_{j t}
$$

Onde:

$P_{j t}=$ preço das açōes da empresa $\mathrm{j}$ no final do ano $t$ (neste caso 1999);

$P_{\mathrm{it}-1}=$ preço das açōes da empresa $\mathrm{j}$ no final do ano $t-1$ (neste caso 1998);

$d_{j t}=$ dividendos distribuidos durante o ano $t$, por ação (1999);

$B V_{p l}=$ patrimônio líquido da empresa $\mathbf{j}$ durante o ano $t$, por ação (1999);

$B V_{\mid t-1}=$ patrimônio liquido da empresa $\mathbf{j}$ durante o ano $t$, por ação (1998);

$\zeta_{j t}=$ termo de erro da regressão. 
Com essa especificação é possivel avaliar, relativamente aos resultados do lucro contábil encontrados na especificação (20), qual a importância do valor do patrimônio por ação para explicar o comportamento do retorno no caso brasileiro. Tem-se as seguintes estatísticas descritivas para as novas variáveis.

TABELA 5.19 Estatísticas Descritivas III

\begin{tabular}{|c|c|c|c|c|c|}
\hline INTANGİVEL & Média & Desvio Padrão & Mediana & Máximo & Mínimo \\
\hline Patrimônio 98 & 0,975603 & 5,276152 & 0,030952 & 32.18001 & 0,000124 \\
\hline Patrimônio 99 & 1,064829 & 5,843077 & 0,030742 & 35.62894 & 0,000158 \\
\hline FIXO & Média & Desvio Padrão & Mediana & Máximo & Mínimo \\
\hline Patrimônio 98 & $-0,058$ & 29,09 & 0,06193 & 145,9656 & -162.1065 \\
\hline Patrimônio 99 & 2,94 & 17,64 & 0,064092 & 151,67875 & -45.82107 \\
\hline
\end{tabular}

Os resultados da regressão 21 estāo sumarizado na tabela abaixo.

TABELA 5.20 Resultados da regressão (21) para os grupos FIXO e INTANGIVEL

\begin{tabular}{|c|c|c|c|c|c|c|}
\hline Grupos & $\mathrm{N}^{0}$ Empresas & $\alpha_{0 t}$ & $\alpha_{1 t}$ & $\alpha_{2 t}$ & $\mathbf{R}^{2}$ & Durbin-Watson \\
\hline INTANGIVEL & 73 & $\begin{array}{c}0,85 \\
(0,0000)\end{array}$ & $\begin{array}{c}0,61 \\
(0,0057)\end{array}$ & $\begin{array}{c}0,39 \\
(0,0000)\end{array}$ & 0,41 & $\begin{array}{c}\text { Ausência de } \\
\text { Autocorrelaçāo }\end{array}$ \\
\hline FIXO & 91 & $\begin{array}{c}1,84 \\
(0,0000)\end{array}$ & $\begin{array}{c}-0,0012 \\
(0,94)\end{array}$ & $\begin{array}{c}0,045 \\
(0,047)\end{array}$ & 0,05 & $\begin{array}{c}\text { Ausência de } \\
\text { Autocorrelação }\end{array}$ \\
\hline TOTAL $^{74}$ & 164 & $\begin{array}{c}1,56 \\
(0,0000)\end{array}$ & $\begin{array}{l}0,0082 \\
(0,60)\end{array}$ & $\begin{array}{c}0,07 \\
(0,0003)\end{array}$ & 0,081 & $\begin{array}{c}\text { Ausência de } \\
\text { Autocorrelaçāo }\end{array}$ \\
\hline
\end{tabular}

Esses resultados demonstram que todos os coeficientes são estatisticamente significantes para o grupo INTANGÍVEL com grande poder explicativo demonstrando que os valores especificados de patrimônio explicam

${ }^{74}$ Mesma regressão realizada para a amostra consolidada. 
satisfatoriamente grande parte do comportamento dos retornos das empresas consideradas. A situação é diferente para 0 grupo FIXO onde o coeficiente $\alpha_{1 t}$ não é estatisticamente significante e o poder explicativo da regressão é comparativamente baixo. Esses resultados demonstram que o comportamento dos dados no Brasil não corrobora a idéia de que empresas do grupo TMT (tecnologia, mídia e telecomunicações) apresentam números contábeis irrelevantes quando comparadas com empresas de setores mais tradicionais. Esses resultados também reforçam a idéia de que o patrimônio possui elevado poder explicativo no Brasil, sendo superior ao lucro contábil.

É natural que a especificação seguinte seja definida para que se possa avaliar o papel conjunto do lucro contábil e do patrimônio na explicação do comportamento dos retornos das empresas dentro da amostra selecionada.

$$
\begin{gathered}
\left(P_{j t}+d_{j t}-P_{j t-1}\right) / P_{j t-1}=\lambda_{0 t}+\lambda_{1 t}\left(B V_{j t}-B V_{j t-1}\right) / P_{j t-1}+\lambda_{2 t}\left(L u c_{j t}-L u c_{j t-1}\right) / P_{j t-1}+ \\
+\lambda_{3 t} B V_{j t} / P_{j t-1}+\lambda_{4 t} L u c_{j t} / P_{j t-1} S_{j t}
\end{gathered}
$$

A especificação acima, utilizando as variáveis definidas anteriormente, pode fornecer uma visão mais clara do papel do lucro contábil e do patrimônio na explicação dos retornos. Os resultados da regressão (22) são apresentados na tabela seguinte. 
TABELA 5.21 Resultados da regressão (22) para os grupos FIXO e INTANGIVEL

\begin{tabular}{|c|c|c|c|c|c|c|c|}
\hline Grupos & $\lambda_{\text {ot }}$ & $\lambda_{11}$ & $\lambda_{2 t}$ & $\lambda_{3 t}$ & $\lambda_{4 t}$ & $\mathrm{R}^{2}$ & $D-W$ \\
\hline INTANGIVEL & $\begin{array}{c}0,89 \\
(0,0000)\end{array}$ & $\begin{array}{c}0,60 \\
(0,0184)\end{array}$ & $\begin{array}{c}-0,33 \\
(0,0009)\end{array}$ & $\begin{array}{c}0,38 \\
(0,0000)\end{array}$ & $\begin{array}{c}0,50 \\
(0,45)\end{array}$ & 0,50 & $\begin{array}{l}\text { Ausência de } \\
\text { Autocorrelação }\end{array}$ \\
\hline FIXO & $\begin{array}{c}1,9289 \\
(0,0000)\end{array}$ & $\begin{array}{c}-0,072 \\
(0,1012)\end{array}$ & $\begin{array}{l}-0,060 \\
(0,051)\end{array}$ & $\begin{array}{c}0,054 \\
(0,021)\end{array}$ & $\begin{array}{c}0,1616 \\
(0,0075)\end{array}$ & 0,13 & $\begin{array}{l}\text { Ausência de } \\
\text { Autocorrelação }\end{array}$ \\
\hline TOTAL & $\begin{array}{c}1,60 \\
(0,0000)\end{array}$ & $\begin{array}{l}-0,064 \\
(0,10)\end{array}$ & $\begin{array}{c}-0,058 \\
(0,0279)\end{array}$ & $\begin{array}{c}0,080 \\
(0,0091)\end{array}$ & $\begin{array}{c}0,1612 \\
(0,0024)\end{array}$ & 0,14 & $\begin{array}{c}\text { Ausência de } \\
\text { Autocorrelação }\end{array}$ \\
\hline
\end{tabular}

Os resultados encontrados acima demonstram que o modelo apresentado pela equação (22) possui poder explicativo superior ao da equação (20). Em relação ao modelo proposto na equação (21) os resultados não são tão superiores como na comparaçāo anterior, mas mesmo assim demonstram um aumento considerável. Relaxando-se um pouco o nivel de significância para 0,10 todos os coeficientes da especificação (22), com exceção do $\lambda_{4 t}$ para o grupo intangível, são aceitos demonstrando a que a maioria dos coeficientes encontrados são robustos do ponto de vista estatístico.

Os resultados apresentados nas regressōes (20), (21) e (22) são importantes no sentido de confirmar os resultados apresentados nas especificaçōes anteriores. Verifica-se que os números contábeis no Brasil são importantes para a explicação tanto do comportamento dos preços como dos retornos. Nesse processo de especificação, o patrimônio líquido possui papel central sendo claramente mais importante do que o lucro contábil. Adicionalmente, verifica-se que as empresas do setor de telecomunicações (caracterizadas no grupo INTANGIVEL) possuem informações contábeis mais relevantes, em termos da explicação dos retornos, do que o grupo FIXO (caracterizado por empresas dos setores: empresas siderúrgicas, têxtil, metalurgia, mecânico industrial, quimico, mineração, petroquímico). Esses resultados claramente vão em desacordo com o tradicionalmente apresentado na literatura (LEV, 1989). 
Continuando no sentido de ampliar os resultados do trabalho, a especificações utilizadas nas regressões 20-22 foram aplicadas para a amostra selecionada inicialmente (Amostra I). Os resultados para a regressão 22 são apresentados na tabela abaixo.

TABELA 5.22 Resultados da regressão (22) para a Amostra I

\begin{tabular}{|c|c|c|c|c|c|c|c|}
\hline Anos & $\lambda_{\text {ot }}$ & $\lambda_{11}$ & $\lambda_{2 t}$ & $\lambda_{3 t}$ & $\lambda_{4 t}$ & $\mathrm{R}^{2}$ & $D-W$ \\
\hline 1996 & $\begin{array}{c}0,42 \\
(0,0000)\end{array}$ & $\begin{array}{c}-0,046 \\
(0,0510)\end{array}$ & $\begin{array}{c}0,016 \\
(0,6120)\end{array}$ & $\begin{array}{c}0,029 \\
(0,0144)\end{array}$ & $\begin{array}{c}0,158 \\
(0,0001)\end{array}$ & 0,18 & $\begin{array}{l}\text { Ausência de } \\
\text { Autocorrelaçã }\end{array}$ \\
\hline 1997 & $\begin{array}{c}0,1889 \\
(0,0011)\end{array}$ & $\begin{array}{l}0,04144 \\
(0,0628)\end{array}$ & $\begin{array}{c}0,0254 \\
(0,3819)\end{array}$ & $\begin{array}{c}0,018 \\
(0,1805)\end{array}$ & $\begin{array}{l}-0,0097 \\
(0,7392)\end{array}$ & 0,06 & $\begin{array}{l}\text { Ausência de } \\
\text { Autocorrelaçã }\end{array}$ \\
\hline 1998 & $\begin{array}{c}-0,207 \\
(0,0000)\end{array}$ & $\begin{array}{l}-0,0977 \\
(0,0003)\end{array}$ & $\begin{array}{c}0,0223 \\
(0,0968)\end{array}$ & $\begin{array}{c}0,0034 \\
(0,3738)\end{array}$ & $\begin{array}{l}0,18887 \\
(0,0000)\end{array}$ & 0,16 & $\begin{array}{l}\text { Ausência de } \\
\text { Autocorrelaçã }\end{array}$ \\
\hline 1999 & $\begin{array}{c}1,0922 \\
(0,0000)\end{array}$ & $\begin{array}{c}0,0509 \\
(0,2402)\end{array}$ & $\begin{array}{l}0,06481 \\
(0,4414)\end{array}$ & $\begin{array}{c}0,1930 \\
(0,0000)\end{array}$ & $\begin{array}{l}-1,1688 \\
(0,0056)\end{array}$ & 0,26 & $\begin{array}{l}\text { Ausência de } \\
\text { Autocorrelaçā }\end{array}$ \\
\hline
\end{tabular}

Os resultados apresentados na tabela acima demonstram que as especificações possuem coeficientes estatisticamente insignificantes em todos os anos considerados e o poder explicativo é bastante baixo, especialmente em 1997. Esses resultados, quando comparados com os apresentados nas regressōes 1 a 10 e 11 a 15a demostram que os números contábeis explicam melhor o comportamento dos preços do que dos retornos dentro da amostra selecionada. Esses resultados são consistentes com os resultados apresentados pelas equações 16 a 19 , que mostram que o lucro contábil não incorpora significativamente o lucro econômico. Esses resultados são consistentes com os apresentados por CARVALHO (1999:81), apesar desse trabalho ter utilizado uma metodologia completamente diferente ${ }^{75}$.

${ }^{75}$ O autor calcula a correlaçāo do lucro contábil com a variação do preço de uma amostra de açōes selecionadas na BOVESPA. 
Surge naturalmente o questionamento do papel do patrimônio dentro da amostra 1. Com esse objetivo, a tabela abaixo apresenta os resultados da regressão 21 para a amostra I.

TABELA 5.23 Resultados da regressão (21) para a Amostra I

\begin{tabular}{|c|c|c|c|c|c|}
\hline Anos & $\alpha_{0 t}$ & $\alpha_{1 t}$ & $\alpha_{2 t}$ & $\mathrm{R}^{2}$ & Durbin-Watson \\
\hline 1996 & 0,366 & 0,004 & 0,048 & 0,09 & $\begin{array}{c}\text { Ausência de } \\
\text { Autocorrelação }\end{array}$ \\
& $(0,0000)$ & $(0,8465)$ & $(0,0001)$ & & $\begin{array}{c}\text { Ausência de } \\
\end{array}$ \\
\hline 1997 & 0,20 & 0,039 & 0,0151 & 0,055 & \\
& $(0,0002)$ & $(0,0218)$ & $(0,1736)$ & & Autocorrelação \\
\hline 1998 & $-0,166$ & 0,0125 & 0,0056 & 0,01 & Ausência de \\
& $(0,0000)$ & $(0,4923)$ & $(0,1708)$ & & Autocorrelação \\
\hline 1999 & 1,2347 & 0,0636 & 0,1656 & 0,23 & Ausência de \\
& $(0,0000)$ & $(0,0001)$ & $(0,0000)$ & & Autocorrelação \\
\hline
\end{tabular}

Os resultados apresentados acima demonstra que, com exceção do ano de 1999 , todos os anos apresentam coeficientes estatisticamente insignificantes com baixo poder explicativo. No entanto, a comparação dos $R^{2}$ da tabela acima com aqueles relativos na tabela 5.22 demonstra que $\circ$ poder explicativo da especificação proposta, apesar de baixo reside quase que exclusivamente no valor do patrimônio.

Para a confirmação dessa situação, avaliando o lucro contábil, a tabela abaixo apresenta os resultados da regressão 20 para a amostra I 
TABELA 5.24 Resultados da regressão (20) para a Amostra I

\begin{tabular}{|c|c|c|c|c|c|}
\hline Anos & $\alpha_{0 t}$ & $\alpha_{1 t}$ & $\alpha_{2 t}$ & $\mathbf{R}^{2}$ & Durbin-Watson \\
\hline 1996 & 0,5541 & 0,0035 & 0,15 & 0,12 & $\begin{array}{c}\text { Ausência de } \\
\end{array}$ \\
& $(0,0000)$ & $(0,9135)$ & $(0,0000)$ & & Autocorrelação \\
\hline 1997 & 0,2291 & 0,0241 & 0,0401 & 0,03 & Ausência de \\
& $(0,0000)$ & $(0,4027)$ & $(0,0312)$ & & Autocorrelação \\
\hline 1998 & $-0,1723$ & 0,0080 & 0,0942 & 0,087 & Ausência de \\
& $(0,0000)$ & $(0,5434)$ & $(0,0001)$ & & Autocorrelação \\
\hline 1999 & 1,7818 & 0,1395 & $-0,0647$ & 0,081 & Ausência de \\
& $(0,0000)$ & $(0,0002)$ & $(0,2891)$ & & Autocorrelação \\
\hline
\end{tabular}

Esses resultados demonstram que o lucro contábil, além de ser insignificante estatisticamente na amostra considerada, não apresenta poder explicativo adicional. Esses resultados também sāo coerentes com os resultados apresentados pelas equações 16 a 19. Assim, confirma-se que o papel do lucro contábil parece ser bastante reduzido no cenário brasileiro confirmando as expectativas.

Adicionalmente, pode-se pensar em modificar a combinação de variáveis realizada anteriormente. Uma questão importante refere-se ao uso de regressores representando os componentes das demonstraçōes contábeis de forma estática e a utilização de regressores representando a variação de uma ano para o outro ${ }^{76}$. Combinando as especificações apresentadas acima propōe-se a seguinte especificação para os componentes do modelo que representam a evolução das variáveis de um ano para outro.

$$
\left(P_{j t}+d_{j t}-P_{j t-1}\right) / P_{j t-1}=\chi_{0 t}+\chi_{1 t}\left(B V_{j t}-B V_{j t-1}\right) / P_{j t-1}+\chi_{2 t}\left(L u c_{j t}-L u c_{j t-1}\right) / P_{j t-1}+S_{j t}
$$

\footnotetext{
${ }^{76}$ Normalmente, os dados advindos do balanço patrimonial são considerados como representativos da estática patrimonial e as in formaçōes da demonstração de resultado são vistas como representantes da dinâmica do fluxo contábil. Na análise realizada nessa seçāo a preocupação é com a utilização de dados pontuais vs. a utilização da variação nas informaçōes de lucro e patrimônio.
} 
Nessa especificação procura-se verificar qual o poder explicativo da evolução das variáveis e não dos respectivos números estáticos. Os resultados dessa especificação são apresentados na tabela abaixo

TABELA 5.25 Resultados da regressão (23) para a Amostra I

\begin{tabular}{|c|c|c|c|c|c|}
\hline Anos & $\chi_{0 t}$ & $\chi_{1 t}$ & $\chi_{2 t}$ & $R^{2}$ & Durbin-Watson \\
\hline 1996 & $\begin{array}{c}0,539 \\
(0,0000)\end{array}$ & $\begin{array}{c}0,0009 \\
(0,9668)\end{array}$ & $\begin{array}{c}0,0610 \\
(0,0708)\end{array}$ & 0,011 & $\begin{array}{c}\text { Ausência de } \\
\text { Autocorrelação }\end{array}$ \\
\hline 1997 & $\begin{array}{c}0,238 \\
(0,0000)\end{array}$ & $\begin{array}{c}0,045 \\
(0,0066)\end{array}$ & $\begin{array}{c}0,0230 \\
(0,4257)\end{array}$ & 0,049 & $\begin{array}{c}\text { Ausência de } \\
\text { Autocorrelação }\end{array}$ \\
\hline 1998 & $\begin{array}{l}-0,1619 \\
(0,0000)\end{array}$ & $\begin{array}{c}0,0151 \\
(0,4110)\end{array}$ & $\begin{array}{l}-0,0029 \\
(0,8313)\end{array}$ & 0,004 & $\begin{array}{c}\text { Ausência de } \\
\text { Autocorrelação }\end{array}$ \\
\hline 1999 & $\begin{array}{c}1,8054 \\
(0,0000)\end{array}$ & $\begin{array}{c}0,0450 \\
(0,3260)\end{array}$ & $\begin{array}{c}0,0443 \\
(0,5921)\end{array}$ & 0,08 & $\begin{array}{c}\text { Ausência de } \\
\text { Autocorrelação }\end{array}$ \\
\hline
\end{tabular}

Antes da análise dos resultados da regressão (23) pode-se especificar, de forma complementar, a seguinte especificação para os termos estáticos do modelo.

$$
\left(P_{j t}+d_{j t}-P_{j t-1}\right) / P_{j t-1}=\Phi_{0 t}+\Phi_{3 t} B V_{j t} / P_{j t-1}+\Phi_{4 t} L u c_{j l} / P_{j t-1} s_{j t}
$$

Verifica-se a diferença em relação à regressão (23). Os resultados da regressāo (24) para a amostra I são apresentados na tabela seguinte. 
TABELA 5.26 Resultados da regressão (24) para a Amostra I

\begin{tabular}{|c|c|c|c|c|c|}
\hline Anos & $\Phi_{0 t}$ & $\Phi_{11}$ & $\Phi_{2 t}$ & $\mathbf{R}^{2}$ & Durbin-Watson \\
\hline 1996 & 0,43 & 0,031 & 0,1288 & 0,16 & $\begin{array}{c}\text { Ausência de } \\
\text { Autocorrelação }\end{array}$ \\
\hline 1997 & $(0,0000)$ & $(0,0096)$ & $(0,0001)$ & & Ausência de \\
& 0,1956 & $(0,0136)$ & 0,0292 & 0,036 & Autocorrelação \\
\hline 1998 & $(0,0007)$ & $(0,3020)$ & $(0,1980)$ & & Ausência de \\
& $-0,1689$ & 0,0039 & 0,0889 & 0,09 & Autocorrelação \\
\hline 1999 & $(0,0000)$ & $(0,3058)$ & $(0,0001)$ & & Ausência de \\
& 1,1871 & 1,1798 & $-0,0456$ & 0,16 & Autocorrelação \\
\hline
\end{tabular}

A comparação dos resultados apresentados nas tabelas 5.25 e 5.26 permite verificar que ambas as especificações possuem coeficientes estatisticamente insignificantes e que o poder explicativo da regressão (24) é superior ao apresentado nos resultados da regressão (23). Outro aspecto que vale a pena ressaltar é que, diferentemente das regressões realizadas com preços como variáveis dependentes, o patrimônio não parece ser melhor especificado para a explicação do comportamento dos retornos do que o lucro contábil. Ambos não apresentam significância estatística para a explicação do comportamento dos retornos. 


\section{CONCLUSŌES E SUGESTÕES PARA FUTURAS PESQUISAS}

Nesta tese foi investigado o papel das informações contábeis para explicar - comportamento dos preços dos títulos negociados na Bolsa de Valores de São Paulo (BOVESPA). A base teórica do trabalho é o modelo de OHLSON (1995) que fornece $\circ$ arcabouço para que se possa relacionar o valor da empresa com informações emanadas diretamente da contabilidade. A análise foi realizada dentro de três áreas gerais: (i) comparação entre o modelo de avaliação baseado em variáveis contábeis e o modelo de avaliação baseado em dividendos futuros, (ii) poder explicativo das variáveis contábeis correntes para explicar preços correntes, (iii) relação entre o reconhecimento do resultado econômico pelo contábil e a assimetria nesse processo. A terceira área foi ligeiramente expandida para analisar a relação dos números contábeis com os retornos de uma nova amostra dividida entre empresas baseadas em ativos intangiveis e fixos.

No final da década de 60 a metodologia de pesquisa em contabilidade começou a migrar de uma abordagem basicamente normativa para uma estrutura positiva onde a evidenciação empírica possui papel central. Dentro dessa nova estrutura metodológica a pesquisa empirica em mercado de capitais (empirical capital markets based accounting research) desenvolveu-se fortemente vindo a constituir o veio principal (mainstream) de investigação contábil internacionalmente. No Brasil, a pesquisa em contabilidade ainda é baseada fundamentalmente em orientações normativas, sendo que o "choque" que provocou o nascimento da abordagem positiva internacionalmente ainda não parece ter influenciado a comunidade contábil no Brasil. Esta dissertação contribui para o desenvolvimento da escola positiva no Brasil na medida que realiza uma investigação empírica baseada em forte fundamentação analítica. 
O estudo do papel da contabilidade como fornecedora de informaçōes para o mercado de capitais é de extrema importância para a avaliação da eficiência da informação contábil no atendimento de alguns de seus mais importantes usuários: analistas e investidores de mercados de capitais. O status da contabilidade como linguagem dos negócios e fornecedora de informações depende diretamente de avaliações empíricas que possibilitem a verificação efetiva da utilização dos números contábeis por seus usuários. O reconhecimento cada vez mais comum do papel dos mercados de capitais para o desenvolvimento econômico aumenta a importância de estudos que contribuem para o entendimento do comportamento e formação de preços nestes mercados e do papel da informação contábil nesse processo.

A dinâmica e as peculiaridades do mercado de capitais brasileiro (aqui referindo-se especificamente à Bolsa de Valores de São Paulo) contrastam com a ausência de informaçōes empiricas acerca do papel da contabilidade nesse mercado. As condições impares de funcionamento do mercado de capitais no Brasil (alta volatilidade, influência governamental, etc.) e as características do modelo contábil no Brasil (altamente regulamentado, fortemente influenciado pela legislação tributária, existência de informações ajustadas pela inflação, etc.) oferecem oportunidades únicas para a realização de pesquisas visando o entendimento do papel da contabilidade nesse mercado.

O mercado de capitais brasileiro é extremamente concentrado com poucas (mais freqüentemente nenhuma) empresas tendo o controle acionário sendo negociado em Bolsa. Nesse tipo de mecanismo de governança corporativa o papel da contabilidade como redutora da assimetria de informações entre administradores e investidores é reduzida uma vez que os proprietários tem acesso privilegiado às informações das empresas. A literatura recente a respeito da relação entre os modelos de governança e a relevância da informação contábil sugere que, nesse tipo de situação, a contabilidade não é relevante para explicar o comportamento de preços negociados no mercado. 
Apesar das considerações apresentadas acima, não existem evidências a respeito do real papel da contabilidade como fornecedora de informações para o mercado de capitais brasileiro. Eșta dissertação contribui para o literatura contábil nacional e internacional fornecendo evidências empiricas que ajudam a suprir a lacuna mencionada acima. Espera-se que os resultados encontrados forneçam evidências robustas o suficiente para aumentar a compreensão do assunto dentro do ambiente brasileiro.

Os resultados apresentados na seção anterior (5.6) permitem que algumas conclusões gerais sejam confeccionadas a respeito da relação entre os preços dos títulos negociados na BOVESPA e informação emanada pelo modelo contábil nacional. Inicialmente pode-se observar que o modelo de avaliação baseado em informações contábeis possui poder explicativo semelhante ao baseado em dividendos futuros. Esse aspecto é interessante pois confirma o desenvolvimento teórico apresentado apresentando sua validade para o mercado brasileiro. Nesse aspecto contribui-se para a teoria contábil e financeira ao se fornecer evidências empiricas acerca dos modelos de avaliação citados.

Ainda em termos de avaliação baseada em informações contábeis e dividendos futuros, encontrou-se forte evidência favorável à hipótese da fixação funcional. Segundo essa hipótese, os investidores são miopicamente focados nos resultados de curto prazo contrariando o tradicionalmente estabelecido no cerne da teoria microeconômica e financeira a respeito da alocação intertemporal de recursos. Pesquisas futuras podem tentar correlacionar esse fenômeno com medidas de risco para o mercado brasileiro.

No que diz respeito à capacidade dos números contábeis correntes para explicar os preços correntes, as evidências encontradas apresentam grande poder explicativo para as informações produzidas no Brasil. Tal poder explicativo, no entanto, concentra-se nos valores do patrimônio líquido e não no lucro como é 
comum na literatura. A explicação definitiva dos motivos desse fenômeno está além do escopo desse trabalho sendo tema interessante para futuras pesquisas. O modelo societário brasileiro com a importância de dados de balanço para finalidades judiciais (especialmente em casos de liquidação) é possivelmente uma das causas de tal fenômeno.

A terceira área de análise investigou o reconhecimento do resultado econômico pelo lucro contábil. Nesse aspecto, verificou-se que o lucro contábil brasileiro não reconhece significativamente o comportamento do resultado econômico conforme esperado de acordo com o modelo de governança corporativo praticado no Brasil. O conservadorismo dos números contábeis apresentados, definido em termos do reconhecimento assimétrico do resultado, apresentou correlação aparente com 0 indice patrimônio/preço (BTM) demonstrando a adequação dos modelos utilizados. As informações sugerem que o conservadorismo no modelo contábil nacional aumentou significativamente no último período analisado.

A última investigação realizada buscou relacionar o papel dos números contábeis com os retornos de uma amostra de empresas divididas entre empresas dos setores mais tradicionais (empresas siderúrgicas, têxtil, metalürgia, mecânico industrial, químico, mineração, petroquímico) e empresas do setor de telecomunicações representando o grupo baseado em ativos intangiveis. Esse estudo foi ampliado para incluir amostra inicial. Os resultados indicam que, de forma geral, as informações emanadas da contabilidade não explicam significativamente o comportamento dos retornos das empresas analisadas. Exceção é feita ao grupo INTANGÍVEL formando por empresas do setor de telecomunicações. Esses resultados são consistentes com os apresentados nas equações 16 a 19 que referem-se ao reconhecimento do resultado econômico pelo lucro contábil. 
O conjunto desses resultados sugere um modelo contábil que efetivamente fornece informações para o mercado de capitais que aparentemente está focado nos resultados de curto prazo. No entanto, esse processo de fornecimento de informações está centrado nos vạlores do patrimônio das empresas estudadas e não no lucro conforme normalmente reportado na literatura. Adicionalmente, tais informações contábeis não parecem ser relevantes para explicar o comportamento dos retornos das empresas analisadas

As implicações desses resultados são de diversas naturezas, dependendo do ponto de vista. Abaixo são relacionados os principais interessados na informação contábil produzida no ambiente brasileiro com as respectivas relações com os resultados encontrados:

- Analistas de Investimento, crédito e investidores em mercados de capitais: para esses usuários a grande mensagem deste trabalho é que a informação contábil está relacionada com o comportamento econômico das empresas analisadas. Esse aspecto denota grande conteúdo informativo das demonstrações contábeis brasileiras implicando que estas são elementos realmente importantes na análise das empresas negociadas em bolsas de valores. Apesar dos problemas de governança corporativa encontrados no mercado nacional, a contabilidade financeira brasileira vem cumprindo o papel de informar os interessados no comportamento do mercado de capitais. No entanto, esse referido conteúdo informativo está contido, quase que exclusivamente nos números do patrimônio. O lucro contábil nāo incorpora significativamente o resultado econômico segundo os resultados encontrados. Esse aspecto sugere uma ligeira mudança de foco na tradicional análise das demonstrações financeiras;

- Órgãos Reguladores: para os reguladores da profissāo contábil e do mercado de capitais brasileiro os resultados encontrados sāo 
promissores e preocupantes. Os resultados são promissores na medida que o modelo contábil brasileiro (advindo de um forte processo de regulamentaçāo) parece ser útil como proxy para o valor das empresas o que demonstra que a contabilidade é importante fonte de informação dentro do contexto analisado. No entanto, os resultados são preocupantes na medida que o lucro contábil não parece ser um indicador de performance econômica confiável no Brasil. Os motivos desses resultados devem ser investigados para que proposiçōes normativas possam ser desenvolvidas com o intuito de resolver esse aparente problema;

- Empresas com ações negociadas em bolsas de valores: para as corporaçōes brasileiras com ações negociadas em bolsas de valores os resultados encontrados vêm confirmar a importância da contabilidade como instrumento de comunicação com o mercado. Por outro lado, a baixa relevância do lucro contábil indica a necessidade de evidenciação adicional de elementos relacionados à performance.

Os pesquisadores e demais interessados na investigação científica em contabilidade constituem um grupo especial de interessados nos resultados deste trabalho e para os quais este é, em última instância, endereçado. As sugestões para pesquisas futuras nesse assunto são de várias naturezas e estão apresentadas abaixo agrupadas de acordo com a visão do autor dos aspectos mais interessantes para discussāo futura:

- Metodologia: trabalhos subsequentes poderiam estar voltados à utilização de event studies para se determinar o conteúdo informativo de disclosures específicos. Nessa linha a investigação da microestrutura do mercado de capitais é fundamental possibilitando a interrelação entre os mecanismos de negociação e o fluxo de informações no mercado. A comparação desses eventuais resultados com os oriundos de estudos 
semelhantes em mercados mais desenvolvidos pode ajudar a esclarecer o processo de formação de preços no mercado nacional. Assim, podese avaliar a "competição" da contabilidade com outras fontes de informação alternativas;

- Fatores relevantes na determinação da relevância da informação contábil: dados os resultados apresentados neste trabalho, quais são os fatores responsáveis por essa situação? Fatores como inflação, taxa de juros, risco sistêmico, etc., impactam a relevância da informação contábil publicada no Brasil. O modelo de correção monetária integral fornece informações superiores ao modelo baseado na legislação societária? Essas e outras questões contribuiriam bastante para o entendimento do papel da contabilidade em mercados menos desenvolvidos;

- Segmentação da base de investidores: os resultados apresentados neste trabalho não diferenciam as reaçōes de investidores sofisticados e não sofisticados. Tal segmentação pode contribuir para $\circ$ entendimento da capacidade de interpretação da informação contábil por parte dos investidores. Os investidores sofisticados no Brasil possuem o mesmo comportamento que em outros paises? Essa segmentação possui alguma influência? Essa é uma área de pesquisa recente e bastante promissora;

- Fundamentação teórica da relevância da informação contábil em mercados emergentes: qual o comportamento esperado dos preços em relação à informação contábil em mercados não desenvolvidos? A reação é exagerada (over-reaction) ou excessivamente modesta (underreaction)? Essas questōes são de natureza analítica e não empírica e envolvem as condições de equilíbrio em situaçōes de assimetria de informação do modelo de precificação. Apesar de ser um tópico 
bastante complicado no cerne da literatura de finanças, esclarecimentos a esse respeito são de enorme importância para a contabilidade;

- Impacto específico do modelo de governança corporativo brasileiro: a idiossincrasia do mercado de capitais brasileiro oferece elementos importantes para o teste de teorias estabelecidas em mercados mais desenvolvidos. Os mecanismos utilizados pelos agentes, especialmente os pequenos acionistas, para reduzir a assimetria de informaçōes nas condiçōes existentes no Brasil merecem investigação mais detalhada. Outros fatores relativos à estabilização econômica brasileira também podem influenciar a relevância da informação contábil abrindo espaço para futuros estudos;

- Impacto da introdução de opções na relevância das informações contábeis: o papel dos mercados de futuros e opções no fluxo de informações no mercado à vista é inegável uma vez que esses produtos catalizam as expectativas dos agentes em relação ao futuro no processo de formação de seus respectivos preços. Dentro desse cenário, a análise do impacto da negociação de opçōes e futuros sobre o papel da contabilidade como fornecedora de informações para o mercado de capitais é, com certeza, uma área de análise com possibilidades importantes de desenvolvimento;

- Diferenças entre empresas da "nova" e "velha" economia: os ativos intangiveis vêm tornando-se mais relevantes para as atividades da empresas nos últimos anos. A relevância da contabilidade para explicar o comportamento dos preços dessas empresas ainda é uma questão em aberto. Trabalhos nesse sentido podem ajudar a entender as diferenças nos resultados, por exemplo, entre as empresas do grupo INTANGIVEL e FIXO. 
Espera-se assim que esta tese tenha contribuido para o entendimento do papel da contabilidade no mercado brasileiro fomentando futuras investigaçōes dentro do paradigma empírico-positivo. 


\section{BIBLIOGRAFIA}

ABARBANELL, J., and Bernard, V., Tests of Analysis Overraction/Underreaction to Earnings Information as an Explanation for Anomalous Stock Price Behaviour. Journal of Finance, p. 1181-1207, July 1992.

ABU-NASSAR, M., RUTHERFORD, B., External Reporting in Less Developed Countries With Moderately Sophisticated Capital Markets: A Study of User Needs and Information Provision in Jordan. In Wallace, R., Samuels, J., Briston, R., and Saudagaran, S., Research In Accounting in Emerging Economies. JAI Press Inc., Stamford Connecticut, 2000.

ACHEN, C. H., Interpreting and Using Regression. Sage Publications, Beverly Hills, p. 82-83, 1982.

AL-BASTEKI, H., Strategies for Enhancing Accounting Profession and Practices in Bahrain: Accounting Experts' Perceptions. In Wallace, R., Samuels, J., Briston, R., and Saudagaran, S., Research In Accounting in Emerging Economies. JAI Press Inc., Stamford Connecticut, 2000.

ALCHIAN, A. Uncertain Evolution, and Economic Theory. Journal of Political Economy, Vol. 58, p.211-221, 1950

ALEXANDER, S., Five Monographs on Business Income. New York: Study Group on Business Income. AICPA, 1950.

ALEXANDER, S., Price Movements in Speculative Markets: Trends or Randon Walks. Industrial Management Review, 2, p. 7-26, 1961.

ALEXANDER, S., Price Movements in Speculative Markets: Trends or Random Walks. Industrial Management Review, p. 7-26, May 1971. 
ALFORD, A.., JONES, J., LEFTWICH, R., ZMIJEWSKI, M., The Relative Informativeness of Accounting Disclosures in Different Countries. Journal of Accounting Research. Supplement to Vol. 31, p. 183-223, 1993.

ALI, Ashiq and Hwang, Lee-Seok. Country-Specific Factors Related to Financial Reporting and the Value Relevance of Accounting Data. Journal of Accounting Research, 38. No 1, p. 1-25, Spring 2000.

AL-RUMAIHI, J. S., POWER, D. M., SINCLAIR, C. D. The Distribution of Financial Ratios of Saudi Arabian Companies. In Wallace, R., Samuels, J., Briston, R., and Saudagaran, S., Research In Accounting in Emerging Economies. JAI Press Inc., Stamford Connecticut, 2000.

AMIN, K. LEE, C.M.C, Option trading price discovery and earnings news dissemination. Comtemporary Accounting Research, Vol. 14, p. 158, 1997.

AMIR, E., and LEV, B., Value-Relevance of Nonfinancial Information: the Wireless Communication industry. Journal of Accounting and Economics, Vol. 22, p. 330, 1996.

ANDERSON, C. W., Financial Contracting Under Extreme Uncertainty: an Analysis of Brazilian Corporate Debentures. Journal of Financial Economics 51, p. 4584, 1999.

ANG, J., Agenda for Research in Pacific-Basin Finance. In Rhee, S., and Chang, R., Eds. Pacific-Basin Capital Market Research, Vol. II, North-Holland, 1991.

ARBEL, A., STREBEL, P., Pay Attention to Neglect Firms. Journal of Portfolio Management, p. 37-42, Winter 1983. 
ARCHBALD, T., Stock Market Reaction to Depreciation Switch-Back. Accounting Review, p. 22-30, January 1972.

ARCHIBALD, T. R., Some Factors Related to the Depreciation Swithback. Financial Analysts Journal, p. 67-73, September-October 1976.

ARIEL, R. A., High Stock Returns Before Holidays: Existence and Evidence on Possible Causes. Journal of Finance, 45, p. 1611-1626, 1990.

ARIEL, R., A Monthly Effect in Stock Returns. Journal of Financial Economics, Vol. $18,1987$.

ASSAF NETO, A. Aspectos da Projeção de Resultados e Análise do Preço de Venda e Ponto de Equilibrio de Empresas Inseridas em Contextos Inflacionários: o Caso Brasileiro. Tese de Doutoramento, FEA-USP, 1983.

ASSAF NETO, A. A Contabilidade e a Gestāo Baseada em Valor. Anais do VI Congresso Brasileiro de Custos. São Paulo; FEA-USP, 1999.

ASQUIT, P., and KIM, E., The Impact of Merger Bids on the Participating Firms' Securities Holders. Joumal of Finance, p. 1209-1228, December 1982.

ASQUIT, P., e MULLINS, D., The Impact of Initiating Dividend Payments on Shareholders' Wealth. Journal of Business, p. 77-96, 1983.

ATHANASSAKOS, G., and FOERSTER, S., Canadian Securities Market Anomalies. In Keim, D., and Ziemba, W., Eds. Security Market Imperfections in World-wide Equity Markets. Cambridge University Press, Cambridge, UK, 2000. 
BACHELIER, L. Theorie de la Speculation. Annales Scientifiques de L'Ecole Normale Superieure. 3d ser., 17: 21-88. Translation in The Random Character of Stock Market Prices, ed. Paul Cootner, Camb. Mass.: MIT Press, p. 17-79, 1964. Da edição original BACHELIER, L. Théorie de la spéculation. Paris, Gauthier-Villars, 1900.

BAER, W., e MILES, W., Introduction. The Quarterly Review of Economics and Finance 40. 2000.

BALL R. J. and BROWN, "An Empirical Evaluation of Accounting Income Numbers," Journal of Accounting Research, Vol. 6, p.159-178, Autumn 1968.

BALL, J., Changes in Accounting Techniques and Stock Prices. Empirical Research in Accounting: Selected Studies. Supplement to Vol. 10 of the Journal of Accounting Research, p. 1-38, 1972.

BALL, R., KOTHARI, S. P., ROBIN, A., The Effect of Institutional Factors On the Properties of Accounting Earnings. Journal of Accounting and Economics. 2000.

BALLESTER, M., and LIVNAT, J., The Association Between Security Prices and Financial Information in the Spanish Stock Market. Journal of International Financial Management and Accounting. Oxford, p. 114-136, 1997.

BANDYOPADHYAY, S. P., HANNA, J. D., RICHARDSON, G., Capital Market Effects of US-Canada GAAP Differences. Journal of Accounting Research, Vol. 32. No 2, p. 262-277, Autumn 1994.

BANZ, R., The Relationship Between Return and Market Value of Common Stocks. Journal of Financial Economics, p. 3-18, March 1981. 
BAO, B., and CHOW, L. The Usefulness of Earnings and Book Value for Equity Valuation in Emerging Capital Markets: Evidence from Listed Companies in the People Republic of China. Joumal of International Financial Management and Accounting, Vol. 10, 2, 1999.

BARTH, M. E., CLINCH, G., SHIBAÑO, T., International Accounting Harmonisation and Global Equity Markets. Journal of Accounting and Economics, Vol. 26, p. 201-235, 1999.

BARTH, M., BEAVER, W., LANDSMAN, W., A Structural Analysis of Pension Disclosures Under SFAS 87 and Their Relation to Share Prices. Financial Analysts Journal, p. 18-26, January-February 1993.

BARTH, M., BEAVER, W., LANDSMAN, W., Market Valuation Implications of Net Periodic Pension Cost. Journal of Accounting and Economics, p. 27-62, March 1992.

BARTH, M., BEAVER, W., LANDSMAN, W., Valuation Characteristics of Equity Book Value and Net Income: Tests of The Abandonment Hypothesis. Working Paper. Stanford University, 1997.

BARTH, M., BEAVER, W., LANDSMAN, W., Value-Relevance of Fair Value Disclosures Under SFAS No 107. Accounting Review, p. 513-537, October 1996.

BARTH, M., CLINCH, G., Scale Effects In Capital Markets-Based Accounting Research. Working Paper. Graduate School of Business, Stanford University. November 1999. 
BARTH, M., Relative Measurement Errors Among Alternative Pension Asset and Liability Measures. Accounting Review, p. 433-463, July 1991.

BARTOV, E., RADHAKRISHNAN, S., KRINSK, I., Investor Sophistication and Patterns in Stock Returns After Earnings Announcements. The Accounting Review, Vol. 75, No 1 p. 43-63, January 2000.

BASU, S., The Conservatism Principle and the Asymmetric Timeliness of Earnings. Journal of Accounting and Economics, p. 78-90, 1997.

BASU, S., The Relationship Between Earnings Yield, Market Value, and Return for NYSE Common Stocks: Further Evidence. Journal of Financial Economics, p. 129-156, June 1983.

BAXTER, W. T., Accounting Standards-Boon or Curse. Emanuel Saxe Distinguished Lectures in Accounting. The City University of New York, New York, p. 25-40, 1979.

BEAVER W. H., "The Information Content of Earnings Announcements" Empirical Research in Accounting: Selected Studies 1968, supplement to Vol. 6 of Journal of Accounting Research, p. 67-92, 1968.

BEAVER, W. H. and LANDSMAN, W. R., Incremental Information Content of Statement 33 Disclosures (Financial Accounting Standards Board, 1983.

BEAVER, W. H. Financial Reporting: An Accounting Revolution. $2^{\text {nd }}$ ed.. Englewood Cliffs.: Prentice Hall, 1998.

BEAVER, W. H., and DEMSKI, J. S., The Nature of Income Measurement. The Accounting Review Vol XIV, p. 39-53, January, 1979. 
BEAVER, W. H., and MORSE, D., What Determines Price-Earnings Ratios? Financial Analysts Journal, p. 65-76, July-August 1978.

BEAVER, W. H., and RYAN, S., Accounting Fundamentals of the Book-to-Market Ratio. Financial Analysts Journal, p. 9-13, November-December 1993.

BEAVER, W. H., G. PARKER. Risk Management: Problems \& Solutions. Stanford University: Financial Services Research Initiative. McGraw-Hill, New York, 1995

BEAVER, W. H., GRIFFIN, P. A. and LANDSMAN, W. R., The Incremental Information Content of Replacement Cost Earnings. Journal of Accounting and Economics, p. 15-39, July 1982

BEAVER, W. H., LANDSMAN, W., Note on the Behaviour of Residual Securities Returns for Winner and Loser Portfolios. Journal of Accounting and Economics, p. 233-242, December 1981.

BEAVER, W., and DEMSKI, J., The Nature of Financial Accounting Objectives: A Summary and Synthesis. Studies in Financial Accounting Objectives. Supplement to Vol. 2 of the Journal of Accounting Research, p. 170-187, 1974.

BEAVER, W., and DUKE, R., Interperiod Tax Allocation and Delta Depreciation Methods: Some Empirical Results. Accounting Review, p. 549-559, July 1973.

BEAVER, W., and MANEGOLD, J., The Association Between Market-Determined and Accounting-Determined Measures of Systematic Risk Journal of Financial and Quantitative Analysis, p. 231-284, June 1975. 
BEAVER, W., and RYAN, S., Biased Recognition (Conservatism) and Delayed Recognition in Accounting and Their Effects in the Ability of the Book-toMarket Ratio to Predict Book Return on Equity. Unpublished Working Paper. New York University, 1996.

BEAVER, W., CLARKE, R., and WRIGHT, W., The Association Between Unsystematic Security Returns and the Magnitude of the Earnings Forecast Error. Journal of Accounting Research, p. 316-340, Autumn 1979.

BEAVER, W., EAGER, S., RYAN, S., and WOLFSON, M., Financial Reporting and the Structure of Bank Share Prices. Journal of Accounting Research, p. 157178, Autumn 1989.

BEAVER, W., KETTLER, P., SCHOLES, M., The Association Between MarketDetermined and Accounting-Determined Risk Measures. Accounting Review, p. 654-682, October 1970 .

BEAVER, W., LAMBERT, R., and RYAN, S., The Information Content of Security Prices: a Second Look. Journal of Accounting and Economics, p. 139-157, July 1987.

BEAVER, W., MORSE, D., What Determines Price-Earnings Rations? Financial Analysts Journal, p. 65-76, July-August 1978.

BEAVER, W., What Should Be the FASB's Objectives? Journal of Accountancy, Vol. 136, p.49-56, August 1973.

BEKAERT, G. and HARVEY, C.R. Emerging Equity Market Volatility. Journal of Financial Economics, Vol. 43 (1), p. 29-77, 1997. 
BENSTON, G., The Value of the SEC'S Accounting Disclosure Requirements. Accounting Review, Vol. 44, p. 515-532, July 1969.

BENSTON, G., There is no Real News in Earnings Reports. Fortune, p. 73-75, April 1976.

BERK, J., A View of The Current Status of The Size Anomaly. In Keim, D., and Ziemba, W., Eds. Security Market Imperfections in World-wide Equity Markets. Cambridge University Press, Cambridge, UK, 2000.

BERNARD, V., and STOBER, T., The Nature and Amount if Information Reflected in Cash Flows. Accounting Review, p. 624-652, October 1989.

BERNARD, V., The Feltham-Ohlson Framework: Implications for Empiricists. Comtemporary Accounting Research, Spring 1995.

BERNARD, V., THOMAS, J., Evidence that Stock Prices Do Not Fully Reflect the Implications of Current Earnings for Future Eamings. Journal of Accounting and Economics, p. 305-340, December 1990.

BERNARD, V., THOMAS, J., Post-Earnings Announcements Drift: Delayed Price Response or Risk Premium? Journal of Accounting Research Supplement, p. $1-48,1989$.

BLACK, F. Yes Virginia, There is Hope: Test of the Value Line Ranking System. Financial Analysts Journal, September-October 1973.

BLACK, F., SCHOLES, M., The Pricing of Options and Corporate Liabilities. Journal of Political Economics, p. 637-654, May-June 1973. 
BLAKE, J., P. WRAITH, and O. AMAT, Management Accounting in Latin America. Management Accounting, p.56-57, April 1998.

BOARD, J. G. L.,, and WALKER, M., Intertemporal and Cross-Sectional Variation in the Association Between Unexpected Accounting Rates of Return and Abnormal Returns. Journal of Accounting Research, Vol. 28, No. 1, Sppring 1990.

BONIN, J., MOSES, E., Seasonal Variations in Prices of Individual Dow-Jones Industrial Stocks. Journal of Financial and Quantitative Analysis, p. 963-991, December 1974.

BOOTH, D., and KEIM, D., Is there Still a January Effect?. In Keim, D., and Ziemba, W., Eds. Security Market Imperfections in World-wide Equity Markets. Cambridge University Press, Cambridge, UK, 2000.

BOOTH, G., KALLUNKI, J-P., MARTIKAINEN, T., Income Smoothing and the Post-Announcement Drift of Earnings: Finish Evidence. Journal of Business Finance and Accounting, Vol. 23, p. 1197-1211, 1996.

BOTOSAN, C., Disclosure Level and the Cost of Capital. The Accounting Review, Vol. 27, No 3, 1997.

BOTOSAN, C., FROST, C., Regulation, Disclosure and Market Liquidity. Working Paper. Washington University and Dartmouth College, 1998.

BOTOSAN, C., SKINNER, D., The Relation Between Post-Earnings Announcements Drift and Option Listink. Workig Paper, University of Michigan, 1993. 
BRADLEY, M., Interfirm Tender Offers and the Market for Corporate Control. Journal of Business, p. 342-276, October 1980.

BRANCH, B., A Tax Loss Trading Rule. Journal of Business, p. 198-207, April 1977.

BREALEY, R. A., and MYERS, S. C., Principles of Corporate Finance. $5^{\text {th }}$ ed. New York: Irwin McGraw-Hill, 1998.

BROMWICH, M. Financial Reporting Information and Capital Makets. Pitman Publishing. London, 1992.

BROMWICH, M. Notas do curso Corporate Financial Reporting. London School of Economics and Political Science. Michaelmas term, 2000.

BROWN, L. D., Influential Accounting Articles, Individuals, Ph.D. Granting Institutions and Faculties: A Citational Analysis. Accounting, Organizations and Society, Vol. 21, No 7/8, p. 723-754, 1996.

BROWN, L., The Impact of Annual Net Profit Report on the Stock Market. The Australian Accountant, p. 277-283, July 1970.

BROWN, P., and KENELLY, J., The Information Content of Quarterly Earnings: An Extension and Some Further Evidence. Journal of Business, p. 403-415, July 1972.

BROWN, P., KEIM, D., KLEIDOM, A., MARSH, T., Stock Returns Seasonalities and the Tax-Loss Selling Hypothesis: Analysis of the Arguments and Australian Evidence. Journal of Financial Economics, p. 105-128, June 1983. 
BROWN, S., LO, K., LYS, T. Use of $R^{2}$ in accounting research: measuring changes in value relevance over the last four decades. Journal of Accounting and Economics, Vol. 28, p. 83-115, 1999.

BULKIEL, G. Notas de Aulas do Curso Empirical Topics in Finance na London School of Economics. London, UK, 2000.

BURGSTAHLER, D., DICHEV, I., Earnings Adaptation and Equity Value. The Accounting Review, Vol. 72, p. 187-215, 1997.

BUSHMAN, R., CHEN, Q., ENGEL, E., The Sensivity of Corporate Governance Systems to the Timeliness of Accounting Earnings. Working Paper. University of North Carolina- Chapell Hill, 2000.

CAMPBELL, J.Y., LO, A.W., MACKINLAY, C. Econometric of Financial Markets. Princeton New Jersey. Princeton University Press, p. 24, 1997.

CANNING, J., The Economics of Accountancy. New York: Ronald Press, 1929

CAREY, K. Non-Random Price Changes in Association with Trading in Large Blocks: Evidence of Market Efficiency in Behaviour of Investor Returns. Journal of Business, p. 407-414, October 1977.

CARNESTRELLI, E., and ZIEMBA, W., Seasonal Anomalies in the Italian Stock Market. 1973-1993. In Keim, D., and Ziemba, W., Eds. Security Market Imperfections in World-wide Equity Markets. Cambridge University Press, Cambridge, UK, 2000. 
CARVALHO, E. L., A Relaçāo entre o EVA® (Economic Value Added) e o Valor das Açōes na Bolsa de Valores do Estado de Sāo Paulo. Dissertação Apresentada à Faculdade de Economia, Administração e Contabilidade da Universidade de Sāo Paulo para obtençāo do Título de Mestre em Contabilidade e Controladoria, 1999.

CATELLi, A., Controladoria. Editora Atlas, São Paulo, 1999.

CHAMBERS, R., Accounting. Evaluation and Economic Behaviour. Englewod Cliffs, N.J.. Prentice Hall, 1966.

CHAN, K.C., SEOW G. S. The Association Between Stock Returns and Foreign GAAP Earnings versus Earnings Adjusted to US. GAAP. Journal of Accounting and Economics, Vol. 21, p. 139-158, 1996.

CHAREST, G., Split Information, Stock Returns and Market Efficiency-1. Journal of Financial Economics, p. 265-296, June-Setember 1978.

CHEN, C., GUL, F., SU, X., A Comparison of Reported Earnings Under Chinese GAAP vs. IAS: Evidence From the Shanghai Stock Exchange. Accounting Horizons, Vol. 13, No 2, p. 91-111, June1999.

CHOI, F., and LEVICH, R., The Capital Market Effects of International Accounting Diversity. Irwin, 1990.

CHU, E., and J. RONEN. Information Content of Accounting Data. Working Paper, Baruch College. CUNY and New York University, 1992.

CHUNG, C. J. and KIM, J., Joumal of International Financial Management and Accounting. Oxford, p. 204-223, 1997 
COENENBERG, A., and BRANDI, E., The Information Content of Annual Accounting Income Numbers of German Corporations: A Review of German Accounting Standards and Some Preliminary Empirical Results. Internationale Arbeitsberichte zur Betriebswirstschaftslehre der Universität Augsburg, Vol 7 , 1996.

COLLINS, D. W., MAYDEW, E. L., WEISS, I. S., Changes in Value-Relevance of Earnings and Book Values over the Past Forty Years. Journal of Accounting and Economics 24, p. 39-67, 1997.

COLLINS, D., and KOTHARI, S., An Analysis of Intertemporal and CrossSectional Determinants of Earnings Response Coefficients. Journal of Accounting and Economics, p. 143-182, July 1989.

COLLINS, D., MAYDEW, E., and WEISS, I., Changes in the Value Relevance of Earnings and Book Values Over the Past Forty Years. Journal of Accounting and Economics, Vol. 24, p. 39-67, 1997.

COMOLLI, L., ZIEMBA. W., Japanese Securities Market Regularities, 1990-1994. In Keim, D., and Ziemba, W., Eds. Security Market Imperfections in Worldwide Equity Markets. Cambridge University Press, Cambridge, UK, 2000.

CONSELHO FEDERAL DE CONTABILIDADE. Resoluçāo No 750. Brasilia, 1983.

COOPER, R., Efficient Capital Markets and the Quantity Theory of Money. Journal of Money, p. 887-908, June 1974.

COOTNER, P., The Random Character of Stock Market Prices. Cambridge: MIT Press, 1964. 
COPELAND, T., MAYERS, D., The Value Line Enigma (1965-1978): A Case Study of Performance Evaluation Issues. Journal of Financial Economics, p. 289322, November 1982.

CROSS, F., The Behaviour of Stock Prices on Friday and Monday. Financial Analysts Journal, p. 67-69, November-December 1973.

ÇURUK T., and COOKE, T., Accounting for Lease Contracts: The Acceptability of International Principles and Practices in Turkey. In Wallace, R., Samuels, J., Briston, R., and Saudagaran, S., Research In Accounting in Emerging Economies. JAI Press Inc., Stamford Connecticut, 2000.

Da COSTA, N. C. A., Overreaction in the Brazilian Stock Market. Journal of Banking and Finance, Vol. 18, p. 633-642, 1994.

da CostA, R., T., Prefácio in Tertuliano, F., Pessoa, I., Aguiar, I., Ayoub, R., Trancanella, R., Rioli, V., (Eds). Full Disclosure: como Aperfeicoar O Relacionamento das Empresas Abertas com o Mercado de Capitais. Editora Maltese São Paulo, p. 11-13, 1993.

DANN, L., MAYERS, D., RAAB, R., Trading Rules, Large Blocks and The Speed of Price Adjustment. Journal of Financial Economics, p. 3-22, 1977.

DARROUGH, M., and T. HARRIS. Do Management Forecasts of Earnings Affect Stock Prices in Japan? In Japanese Financial Market Research, edited W. T. Ziemba, W. Bailey, and Y. Hameo, Amsterdan: North-Holand, p. 197-229, 1991.

DAVIDSON, S., and WEILL R., Inflation Accounting: Public Utilities: Financial Analysts Journal, Vol. 31, p. 30-34, 62 (b), May-june 1975. 
DAVIDSON, S., and WEILL R., Inflation Accounting: What Will Generate Price Level Adjusted Income Statements Show? Financial Analysts Journal, Vol. 31, p. 27-31 (a), January-February 1975.

DAVIDSON, S., STICKENEY C., and WEILL R., Inflation Accounting. New York: McGraw-Hill, 1976.

DAVIES, P., and CANES, M., Stock Prices and the Publication of Second-Hand Information. Journal of Business, p. 43-56, January 1978.

DAVIS-FRIDAY, P. and RIVERA, J., Inflation Accounting and 20-F Disclosures: Evidence from Mexico. Accounting Horizons, Vol. 14, No2, 2000.

DAVIS-FRIDAY, P., FOLAMI, L.B., LIU, C.S., MITTELSTAEDT, F. The Value Relevance of Financial Statement Recognition versus Disclosure: Evidence form SFAS No 106. The Accounting Review, No 4, 1999.

DEBONDT, W., The Psychology of Over-Reaction and Under-Reaction in World Equity Markets. In Keim, D., and Ziemba, W., Eds. Security Market Imperfections in World-wide Equity Markets. Cambridge University Press, Cambridge, UK,2000.

DECHOW, P., SLOAN, R., and SWEENEY, A., The Relation Between Affiliated Analysts' Long -Term Earnings Forecasts and the Overpricing of Equity Offerings. Unpublished Working Paper. University of Pennsylvania Wharton, 1996.

DEMSKI, J.S. e FELTHAM, G. A. Cost Determination: a Conceptual Approach. lowa State University Press, 1976. 
DIGA, J. G., SAUDAGARAN, S. M., Pre-1998 Reforms in Financial Reporting in Indonesia: the Impact of Capital Market Developments. In Wallace, R., Samuels, J., Briston, R., and Saudagaran, S., Research in Accounting in Emerging Economies. JAI Press Inc., Stamford Connecticut, 2000.

DIMSON, E., MARSH, P., The Demise of Size. In Keim, D., and Ziemba, W., Eds. Security Market Imperfections in World-wide Equity Markets. Cambridge University Press, Cambridge, UK, 2000.

DIVECHIA, A.B., DRACH, J., STEFEK, D. Emerging Markets: a Quantitative Perspective. The Journal of Portfolio Management, Vol. 19 (1), p. 41-50, Fall 1995.

DODD, P., and RUBACK, R., Tender Offers and Stockholders Returns: An Empirical Analysis. Journal of Financial Economics, p. 351-373, December 1977.

DODD, P., Merger Proposals Management Discretion and Stockholder Wealth. Journal of Financial Economics, p. 105-138, June 1980.

DOTHAN, M. U., Prices in Financial Markets. New York, NY: Oxford University Press, 1990.

DOUPNIK, T. S., E. MARTINS., G. BARBIERI., Inovations in Brazilian Inflation Accounting. The International Journal of Accounting, Vol. 30, p. 302-317, 1995.

DUFFIE, D., Dynamic Asset Pricing Theory. $2^{\text {nd }}$ Edition. Princeton, NJ: Princeton University Press, 1996. 
DUREVALL, D. Inertial Inflation, Indexation and Price Stickiness: Evidence from Brazil. Journal of Development Economics, Vol. 60, p. 407-421, 1999.

DYCKMAN, T. R., The Effects of Restating Financial Statements for Price-Level Changes: a Comment. The Accounting Review, Vol. 50, No 4, p.796-808, 1975.

DYCKMAN, T., and D. MORSE. Efficient Capital Markets and Accounting: A Critical Analysis. $2^{\text {nd }}$ ed.. Englewood Cliffs.: Prentice Hall, 1986.

DYL, E., Capital Gains Taxation and Year-End Stock Market Behaviour. Journal of Finance, p. 165-175, March 1977.

EASTON, P., Accounting Earnings and Security Valuation: Empirical Evidence of the Fundamental Links. Journal of Accounting Research, Vol. 23, p. 54-77, 1985.

EASTON, P., and HARRIS, T., Earnings as an Explanatory Variable for Retums. Journal of Accounting Research, p. 19-36, Spring 1991.

EASTON, P., and ZMIJEWSKI, M., Cross-Sectional Variance in the Stock Market Response to Accountng Eamings Measurements. Journal of Accounting and Economics. P. 117-142, 1989

EDEY, H. C., Business Valuation, Goodwill and the Super-profit Method. Accountancy, January-February 1957.

EDWARS, E., and BELL, P., The Theory of Measurement of Business Income. Berkeley: University of Califomia Press, 1961. 
ELLIOT, J., HANA, J., Repeated Accounting Write-offs and the Information Content of Earnings. Supplement to Journal of Accounting Research, Vol. 34, p. 135$155,1996$.

ELLIOT, J., HANNA, J., SHAW, W., The Evaluation by the Financial Markets of Changes in Bank Loans Loss Reserves Levels. Accounting Review, Vol. 1, p. 847-861, October 1991.

ELTON, E., GRUBER, M., Marginal Stockholders Tax Rates and the Clentele Effect. Review of Economics and Statistics, p. 68-74, February 1970.

ENG, L.L., KHOO, A., TAN, R., Communication of Private Information and the Valuation of Initial Public Offering in Singapore. Journal of International Financial Management and Accounting. Oxford, p. 63-82, 1998.

FAMA E. Fisher, L., JENSEM, M., and ROLL, R., The Adjustment of Stock Prices to New Information. International Economic Review, p. 1-21, February 1969.

FAMA, E. Efficient Capital Markets: A Review of Theory and Empirical Work. Journal of Finance, May 1970.

FAMA, E., and BLUME, M., Filter Rules and Stock Market Trading. Journal of Business, p. 226-241, January 1966.

FAMA, E., Efficient Capital Markets: II. Journal of Finance, p. 1575-1617, December 1991.

FAMA, E., FRENCH, K., The Cross-Section of Expected Stock Retums. Joumal of Finance, p. 427-465, July 1992. 
FAMA, E., Risk Adjusted Discount Rates and Capital Budgeting under Uncertainty. Journal of Financial Economics 5, p. 3-24, August 1977.

FAMA, E.; The Behaviour of Stock Market Prices. Journal of Business, p. 34-105, January 1965.

FAMÁ, R. Sistema de Informação Contábil e Financeira na Gestão Privada, Pública, Direta e Sociedades de Economia Mista. Revista Univille vol.3 No 1, 1998, p. 114-127, Joinville.

FAMÁ, R. Liquidez e a Teoria dos Elementos Causadores de Insolvência. Caderno de Pesquisas em Administração. Vol. 1, No. 12, p. 10-21, São Paulo, 2000.

FASB. Statement of Accounting Concepts No 2. Qualitative characteristics of Accounting Information. New Haven, 1978.

FASB. Statement of Financial Accounting Standards No 7. Disclosure About Fair Value of Financial Instruments. New Haven, 1997.

FELTHAM, G. A., OHLSON, J.A. Residual Earnings Valuation With Risk and Stochastic Interest Rates. The Accounting Review, Vol 74, No 2, p. 165-183, 1999.

FELTHAM, G. A., OHLSON, J.A. Valuation and Clean Surplus Accounting for operating and financial activities. Contemporary Accounting Research, Vol. 11, p. 689-731, 1995.

FINANCIAL TIMES. Brazil: Finance and Investment. Wednesday, December, 20,p. 13-19, 2000. 
FINNERTY, J., Insiders and Market Efficiency. Journal of Finance, p. 1141-1148, September 1976.

FISHER, G.R., and MCALEER, M.J., Alternative Procedures and Associated tests of Significance for Non-nontested Hypothesis. Journal of Econometrics, Vol. 16, p. 103-119, 1981.

FLEURY, A., Quality and Productivity in the Competitive Strategies of Brazilian Industrial Enterprises. World Development, Vol. 23, p. 73-85, 1995.

FORSGARDH, L., and HERTZEN, K., The Adjustment of Stock Prices to New Earnings Information: A Study of the Efficiency of the Swedish Stock Market. In International Capital Markets, edited by E. Elton and M. Gruber, Amsterdam: North-Holand, 1975.

FOSTER, G. Briloff and the Capital Markets. Journal of Accounting Research, p. 262-274, Spring 1979.

FOSTER, G. Financial Statement Analysis. $2^{\text {nd }}$ ed. Englewood Cliffs.: Prentice Hall, 1986.

FOSTER, G., OLSEN, C., and SHEVLIN, T., Earnings Release Anomalies and the Behaviour of Security Returns. Accounting Review, p. 574-603, October 1984.

FRENCH, K., Stock Returns and the Weekend Effect.. Journal of Financial Economics, p. 55-69, March 1980.

FROST, C. A., and POWNALL, G., Accounting Disclosure Practices in the United States and the United Kingdom. Journal of Accounting Research, Vol. 32, No 1, p. 75-102, Spring 1994. 
GARCIA, M. G. P., Avoiding Some Costs of Inflation and Crawling Toward Hyperinflation. Joumal of Development Economics, Vol. 51, p. 139-159, 1996.

GAZETA MERCANTIL. O Mercado paga pouco para ter direito a voto. São Paulo, p. C-1, 22 de Dezembro de 2000.

GIBBONS, M., and HESS, P., Day of the Week Effects and Asset Returns. Journal of Business, p. 579-596, October 1981.

GIVOLY, D., and LAKONISHOK, T., The Information Content of Financial Analysts Forecast of Earnings: Some Evidence on Semi-Strong Inefficiency. Journal of Accounting and Economics, p. 165-186, December 1979.

GODFREY, L.G., Testing Non-nontested Models After Estimation by Instrumental variables or least squares. Econometrica, Vol. 51, p. 355-365, 1983.

GOMES, A., Going Public Without Governance: Managerial Reputation Effects. Journal of Finance, Vol. 55, No 2, April 2000.

GONEDES, N., and DOPUCH, N. Capital Market Equilibrium, Information Production, and Selecting Accounting Techniques: Theoretical Framework and Review of Empirical Work. Studies on Financial Accounting Objectives, Suplement to Vol. 12 of Journal of Accounting Research, p. 48-130, 1974.

GRANGER, C.; and MORGENTEIN, O; Spectral Analysis of New York Stock Market Prices. Kylklos, Vol. 16, p. 1-27, 1963.

GRANJER, C., and MORGENSTEIN, O. Spectral Analysis of New York Stock Market Prices, Kyklos, 16, p. 1-27, 1963. 